UNIVERSIDADE DE BRASÍLIA

FACULDADE DE AGRONOMIA E MEDICINA VETERINÁRIA

PROGRAMA DE PÓS-GRADUAÇÃo EM AGRONOMIA

QUALIDADE DO SOLO E APTIDÃO AGRÍCOLA DAS TERRAS DO QUILOMBO MESQUITA, ESTADO DE GOIÁS

ROBERVONE SEVERINA DE MELO PEREIRA DO NASCIMENTO

TESE DE DOUTORADO EM AGRONOMIA 


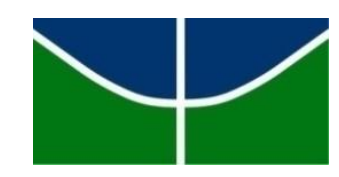

UNIVERSIDADE DE BRASÍLIA

FACULDADE DE AGRONOMIA E MEDICINA VETERINÁRIA

PROGRAMA DE PÓS-GRADUAÇÃO EM AGRONOMIA

\section{QUALIDADE DO SOLO E APTIDÃO AGRÍCOLA DAS TERRAS DO QUILOMBO MESQUITA, ESTADO DE GOIÁS}

ORIENTADORA: Prof. ${ }^{a}$ PhD. Maria Lucrécia Gerosa Ramos

TESE DE DOUTORADO EM AGRONOMIA

PUBLICAÇÃO: 045D/2016

BRASÍLIA/DF

JUNHO/2016 


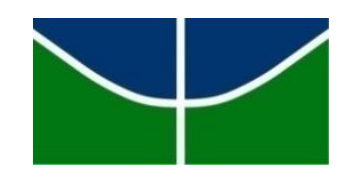

UNIVERSIDADE DE BRASÍLIA

FACULDADE DE AGRONOMIA E MEDICINA VETERINÁRIA

PROGRAMA DE PÓS-GRADUAÇÃO EM AGRONOMIA

\title{
QUALIDADE DO SOLO E APTIDÃO AGRÍCOLA DAS TERRAS DO QUILOMBO MESQUITA, ESTADO DE GOIÁS
}

\author{
ROBERVONE SEVERINA DE MELO PEREIRA DO NASCIMENTO
}

TESE DE DOUTORADO SUBMETIDA À FACULDADE DE AGRONOMIA E MEDICINA VETERINÁRIA DA UNIVERSIDADE DE BRASÍLIA, COMO PARTE DOS REQUISITOS NECESSÁRIOS À OBTENÇÃO DO GRAU DE DOUTOR EM AGRONOMIA.

\section{APROVADO POR:}

MARIA LUCRÉCIA GEROSA RAMOS, PhD. (UnB - FAV)

(ORIENTADORA), email: lucrecia@unb.br

MARILUSA PINTO COELHO LACERDA

(EXAMINADORA INTERNA), email: marilusa@unb.br

ALESSANDRA MONTEIRO DE PAULA

(EXAMINADORA INTERNA, email: alessandra.monteiro@unb.br

ARMINDA MOREIRA DE CARVALHO

(EXAMINADORA EXTERNA), email: arminda.carvalho@embrapa.br

ROBÉLIO LEANDRO MARCHÃO

(EXAMINADOR EXTERNO), email: robelio.marchao@embrapa.br

BRASÍLIA/DF, 30 de JUNHO de 2016. 


\section{FICHA CATALOGRÁFICA}

Nascimento, Robervone Severina de Melo Pereira do Nascimento

Qualidade do solo e aptidão agrícola das terras do Quilombo Mesquita, Estado de Goiás.

203p. : il.

Tese de doutorado (D) - Universidade de Agronomia/Faculdade de Agronomia e Medicina Veterinária, 2016.

1.Matéria orgânica do solo; 2. Atributos de qualide do solo; 3. Ocupação das terras

5. Planejamento agrícola; 6. Sistema de informações geográficas.

I. Ramos, M.L.G. II. PhD.

\section{REFERÊNCIA BIBLIOGRÁFICA}

NASCIMENTO, R.S.M.N.; Qualidade do solo e aptidão agrícola das terras do Quilombo Mesquita, Estado de Goiás. Brasília: Faculdade de Agronomia e Medicina Veterinária, 2016, 203p. Tese de Doutorado.

\section{CESSÃO DE DIREITOS}

NOME DO AUTOR: Robervone Severina de Melo Pereira do Nascimento

TÍTULO DA TESE: Qualidade do solo e aptidão agrícola das terras do Quilombo Mesquita, Estado de Goiás

GRAU: Doutor ANO: 2016

É concedida à Universidade de Brasília A permissão para reproduzir cópias desta tese de doutorado para única e exclusivamente propósitos acadêmicos e científicos. $\mathrm{O}$ autor reserva para si os outros direitos autorais, de publicação. Nenhuma parte desta tese de doutorado pode ser reproduzida sem a autorização por escrito do autor. Citações são estimuladas, desde que citada à fonte.

Nome: Robervone Severina de Melo Pereira do Nascimento

CPF: 692.656.741-72

Email: robervone@ hotmail.com 
Por uma Universidade mais produtiva, onde os recursos utilizados retornem na forma de benefícios para a sociedade!

Thomaz Wood Jr. 
Aos meus antepassados,

especialmente aos meus avós (Maria e Benedito - in memorian).

Aos meus pais, Roberto e Ivone.

À família quilombola que constituí,

Denildo "Biko" (esposo), Davi (filho) e Vitória (enteada - in memorian).

Pelo incentivo e motivação nessa trajetória acadêmica.

DEDICO

Aos agricultores familiares quilombolas do Brasil, e, especialmente à Comunidade do Quilombo Mesquita.

Pela inspiração e aprendizado. 


\section{AGRADECIMENTOS}

À Deus que sempre me iluminou e esteve presente em cada momento de minha caminhada. Aos meus irmãos Ivoney, Júnior e Roberta, e, ao meu sobrinho Rodrigo, que me ajudaram em muitos momentos, sempre com muita paciência e presteza.

Aos agricultores quilombolas, Roberto, Tereza e "Tonho", Dona Elpidia e Seu Antônio, e José Hiládio, que cederam suas propriedades para a implantação do projeto de Tese.

À Sandra Pereira Braga por ser um exemplo de luta pelos direitos e pela regularização fundiária do Quilombo Mesquita e pelo apoio dado para a execução desse trabalho.

A CONAQ pelo exemplo de militância repassada.

Aos professores da graduação que me incentivaram a trabalhar com pesquisa Clístenes W.A. do Nascimento e Gustavo P. Duda da Universidade Federal Rural de Pernambuco (UFRPE). À professora Lucrécia Ramos pelos ensinamentos, dedicação, confiança, carinho, por ter acreditado em meu potencial e pela orientação nesta etapa, aqui concluída.

Aos professores Cícero Célio, Alessandra de Paula, Helson Vale e Marilusa Lacerda pelas contribuições ao longo da realização deste estudo.

Ao Manuel pelas valiosíssimas conversas, por todo conhecimento a mim transferido, pela contribuição dada em todas as etapas desse trabalho e pela paciência ao escutar as minhas angústias.

Aos estagiários do Laboratório de Microbiologia do Solo - UnB, especialmente Antonio Marcos Miranda e Silva e Stefany Braz Silva, pela alegria, animação, companheirismo, auxílio em cada etapa deste trabalho. Essa é uma dupla de ouro!

Aos companheiros de pós graduação Manuel, Márcia Veras, Daniel, Catharine, Geissinay, Daiane e Alberto pelas conversas e auxílio nessa tese.

Ao Instituto Nacional de Colonização e Reforma Agrária (INCRA) e à Universidade de Brasília pela oportunidade de realizar este curso de pós-graduação com ampliação de meus conhecimentos.

À todos que contribuíram para o meu crescimento pessoal e profissional!

MUITO OBRIGADA! 
RESUMO GERAL

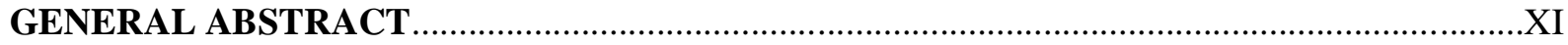

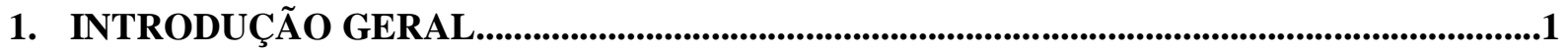

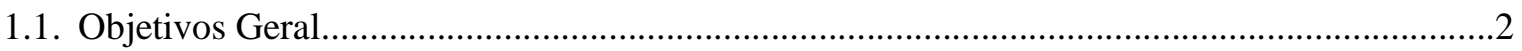

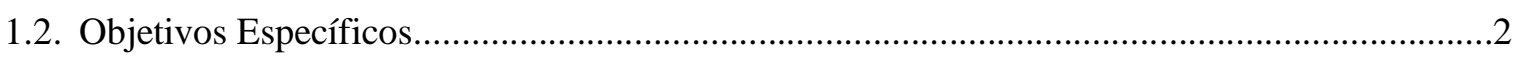

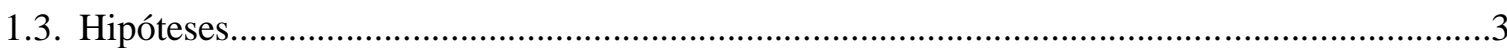

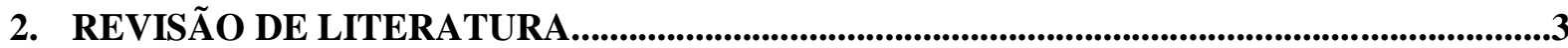

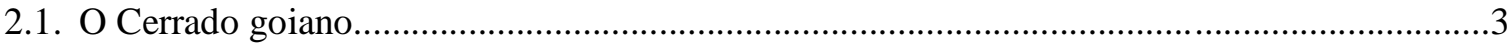

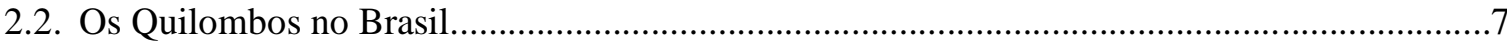

2.2.1. A dificuldade do acesso a terra e demais direitos....................................................

2.2.2. A Comunidade Quilombola de Mesquita...............................................................12

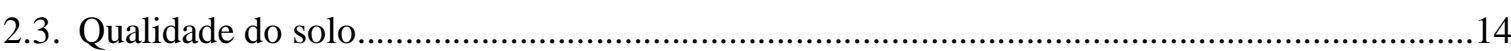

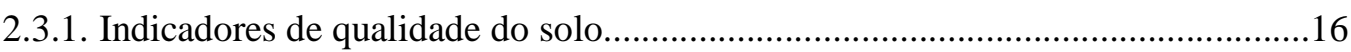

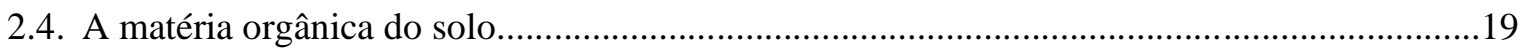

2.4.1. Dinâmica da matéria orgânica em solos do Cerrado...............................................21

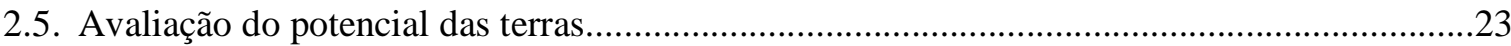

2.5.1.Sistema de Avaliação da Aptidão Agrícola................................................................24

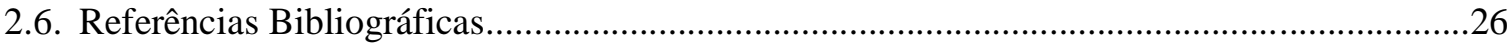

3. CAPítulo 1. APTIDÃo agrícola das terras E CARACTERIZAÇÃo de LATOSSOLOS DO QUILOMBO MESQUITA, GO

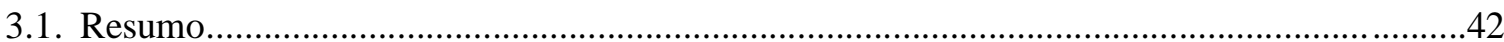

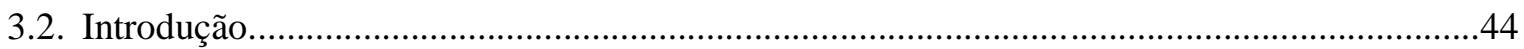

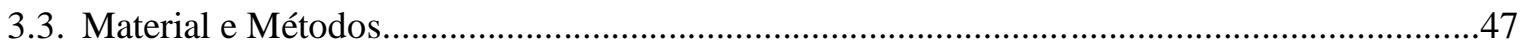

3.3.1. Localização e clima da área de estudo...................................................................47

3.3.2. Elaboração dos mapas de caracterização física, de aptidão agrícola e de uso e

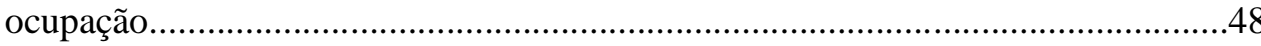

3.3.3. Caracterização e classificação dos Latossolos do Quilombo..................................55

3.3.3.1. Análises laboratoriais.......................................................................56

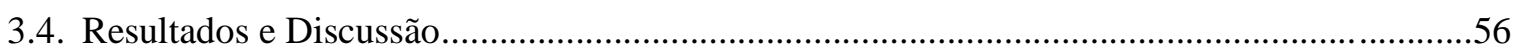

3.4.1. Caracterização do meio físico do Quilombo.........................................................56

3.4.2. Uso e ocupação das terras em comparação à aptidão agrícola do Quilombo

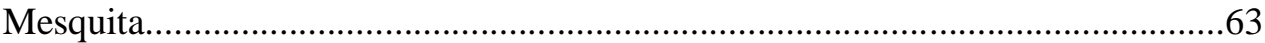




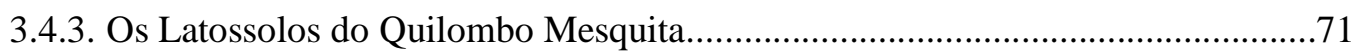

3.4.3.1. Atributos morfológicos...................................................................72

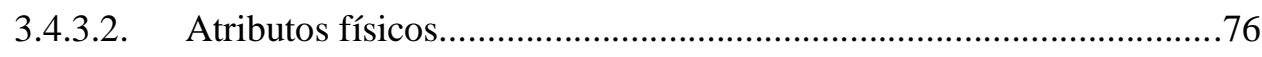

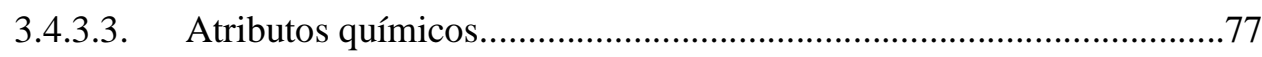

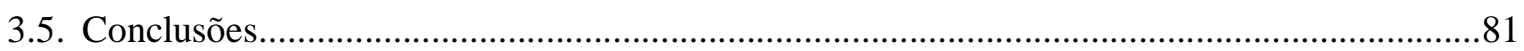

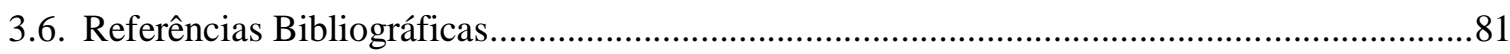

4. CAPÍTULO 2. ATRIBUTOS DO SOLO SOB DIFERENTES USOS DA TERRA POR AGRICULTORES QUILOMBOLAS EM GOIÁS

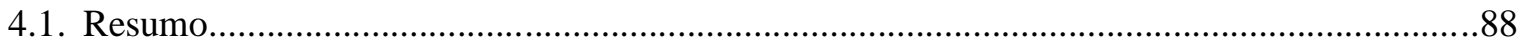

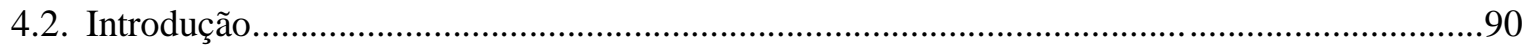

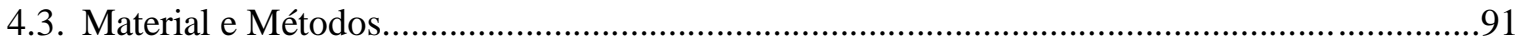

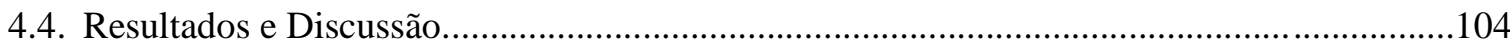

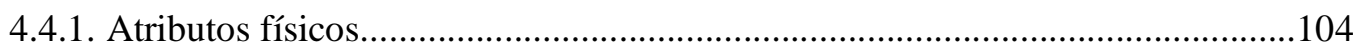

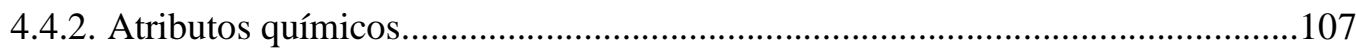

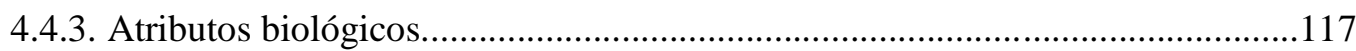

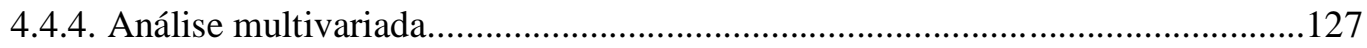

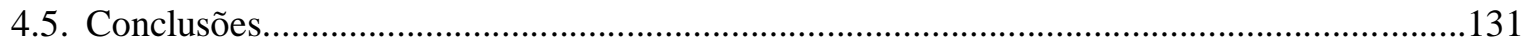

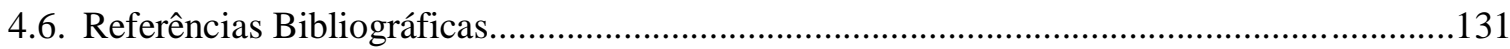

5. CAPÍtUlo 3. COMPARTIMENTOS DA MATÉRiA ORGÂNiCA DO SOLO SOB DIFERENTES USOS DA TERRA

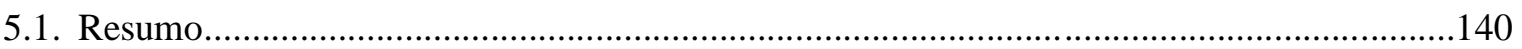

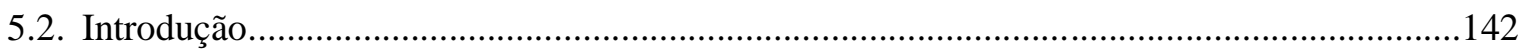

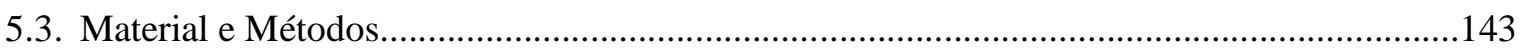

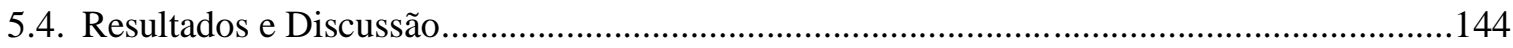

5.4.1. Carbono orgânico total e em substâncias húmicas.............................................145

5.4.2. Efeitos dos sistemas de uso do solo na labilidade da matéria orgânica................150

5.4.3. Análise de componentes principais.....................................................................154

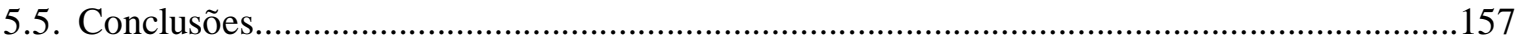

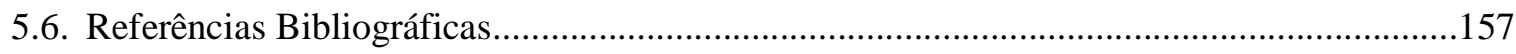

6. CAPÍTULO 4. CARBONO E NITROGÊNIO NAS FRAÇÕES GRANULOMÉTRICAS DE UM LATOSSOLO SOB DIFERENTES USOS DA TERRA

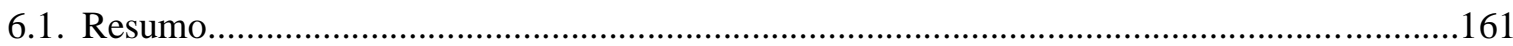

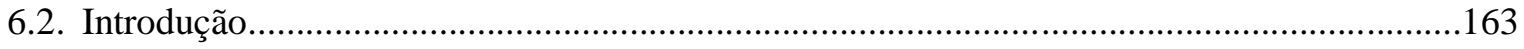

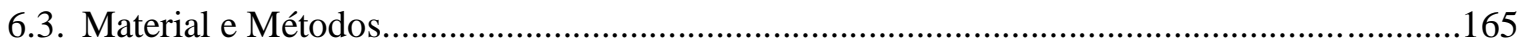


6.4. Resultados e Discussão.

6.4.1. Teor e distribuição de $\mathrm{C}$ e $\mathrm{N}$ nas frações granulométricas da matéria

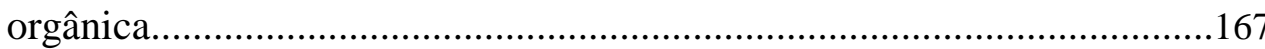

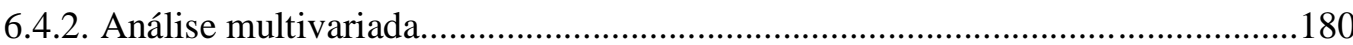

6.4.3. Relação dos estoque de $\mathrm{C}$ e $\mathrm{N}$ entre sistemas de manejo e áreas nativas

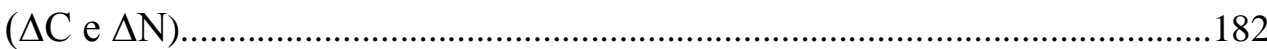

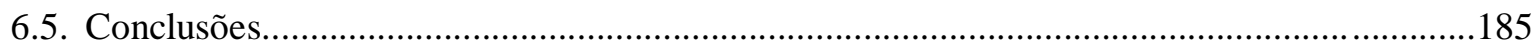

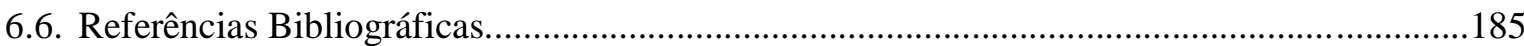




\section{LISTA DE SIGLAS}

FCP: Fundação Cultural Palmares

INCRA: Instituto Nacional de Colonização e Reforma Agrária

ADCT: Atos das Disposições Constitucionais Transitórias

OIT: Organização Internacional do Trabalho

IBGE: Instituto Brasileiro de Geografia e Estatística

CONAQ: Coordenação Nacional das Comunidades Quilombolas

MDS: Ministério do Desenvolvimento Social

RTID: Relatório Técnico de Identificação e Delimitação

SIEG: Sistema Estadual de Geoinformação de Goías

SRTM: Missão Topográfica Radar Shutle

USGS: Science for a Changing World

CER: Cerradão

CSS: Cerrado sensu stricto

TCC: Tangerina com consórcio

TSC: Tangerina sem consórcio

CG1: Plantio convencional de grãos 1

CG2: Plantio convencional de grãos 2

PB: Pastagem de braquiárias

PNB: Pastagem de plantas nativas e braquiárias 


\section{QUALIDADE DO SOLO E APTIDÃO AGRÍCOLA DAS TERRAS DO QUILOMBO MESQUITA, ESTADO DE GOIÁS}

\section{RESUMO GERAL}

Os quilombolas, descendentes de africanos escravizados, estão com a qualidade de seus solos ameaçada, devido não somente a expropriação de suas terras, como pela ausência de políticas públicas de inclusão produtiva. Nesse cenário, o estudo da qualidade dos solos, vinculado ao uso de metodologias de avaliação da aptidão das terras é essencial para a garantia da sustentabilidade dos sistemas agrícolas implantados. No Quilombo Mesquita, localizado no estado de Goiás, foi gerado o mapa de aptidão agrícola e de uso e ocupação de suas terras, bem como foram determinados os atributos físicos, químicos e biológicos, e o carbono (C) e nitrogênio $(\mathrm{N})$ total e nas frações lábeis e estáveis da matéria orgânica do solo. Para tanto, foram estudados oito usos da terra, sendo quatro no Cerradão (Cerradão; Pastagem de braquiárias; Plantio convencional de grãos1; Tangerina com consórcio), e, outros quatro no Cerrado sensu stricto (Cerrado sensu stricto; Pastagem de plantas nativas e braquiárias; Plantio convencional de grãos2; Tangerina sem consórcio), visando estudar o impacto desses usos da terra na qualidade dos solos do Quilombo, bem como avaliar a aptidão agrícola de suas terras. As amostragens foram feitas em abril de 2014. Os dados foram submetidos à análise de variância e as médias comparadas pelo teste de Tukey a 5\% de probabilidade. Verificou-se que em mais da metade da área do Quilombo é praticada alguma atividade agrícola, seja com culturas anuais ou perenes, e, ou pastagens, havendo muitas áreas com solos expostos, cujo sistema de manejo do uso da terra necessita ser adequado. O estudo demonstrou ainda que os usos da terra pautados em sistemas convencionais alteraram negativamente os atributos do solo e reduziram a qualidade da matéria orgânica, quando comparados com a área nativa. O estudo dos solos do Quilombo Mesquita visou gerar dados preliminares para o monitoramento da sustentabilidade e fomento de pesquisas e de políticas públicas de inclusão produtiva em áreas de expressivo potencial de produção de alimentos, especialmente para esse segmento da agricultura familiar que se encontra em insegurança alimentar.

Palavras chave: matéria orgânica do solo, atributos de qualidade do solo, ocupação das terras, planejamento agrícola, sistema de informações geográficas. 


\section{SOIL QUALITY AND SUITABILITY OF AGRICULTURAL LAND IN MESQUITA QUILOMBO AT GOIAS}

\section{GENERAL ABSTRACT}

Quilombolas, descendants of enslaved Africans, are with the quality of their soils threatened because not only the expropriation of their land, as the lack of public policies for productive inclusion. In this scenario, the study of soil quality, linked to the land use of the suitabilituy assessment methodologies is essential for ensuring the sustainability of agricultural systems deployed. In Quilombo Mesquita, located in the state of Goias, it was generated map of agricultural suitability and use and occupation of their land and were determined the physical, chemical and biological attributes, and carbon $(\mathrm{C})$ and nitrogen $(\mathrm{N})$ total and the labile and stable fractions of soil organic matter. Therefore, eight land uses were studied, four in Cerradão (Cerradão; Brachiaria Pasture, Conventional planting grain1; Tangerine with consortium), and four others in Cerrado sensu stricto (Cerrado sensu stricto; Pasture native and Brachiaria plants; Conventional planting grain2; Tangerine without consortium), to study the impact of land use on the quality of Quilombo soils and evaluate the agricultural potential of their land. The samples were taken in April 2014. The data were submitted to analysis of variance and the means compared by Tukey test at $5 \%$ probability. It was found that in more than half of the Quilombo area is practiced some agriculture, either with annual or perennial crops and pastures or, with many areas with exposed soil, whose management system of land use needs to be appropriate. The study also showed that the land use guided in conventional systems adversely alter the attributes of the soil and reduced the quality of organic matter compared to the native area. The study of Quilombo Mesquita soil aimed at generating preliminary data for monitoring the sustainability and development of public research and policy productive inclusion in significant food production potential areas, especially for this segment of family farming that is food insecure.

Keywords: soil organic matter, soil quality attributes, land occupation, land use planning, geographic information system. 


\section{INTRODUÇÃO GERAL}

As comunidades quilombolas, herança da resistência dos negros ao sistema escravagista, começaram a se formar no século XVI, vivendo praticamente da agricultura familiar (Fidelis \& Bergamasco, 2013; Lucena et al., 2016). Quase cinco séculos depois, esse tipo de organização permanece de forma expressiva em todo Brasil. Dados da Fundação Cultural Palmares (FCP, 2016) revelam que existem mais de duas mil e seiscentas comunidades reconhecidas/certificadas como remanescentes de quilombos e, destas, trinta e três estão no Estado de Goiás.

Considerando que Goiás é o único estado da Federação totalmente inserido no Bioma Cerrado (Carvalho \& Bayer, 2008; Carvalho et al., 2009, Ferreira et al., 2009), com solos altamente intemperizados, de baixa fertilidade e acentuada acidez (Reatto \& Martins, 2005; Vendrame et al., 2010) com aptidão para a agricultura tecnificada, os agricultores quilombolas, a partir de uma lógica camponesa, sobrevivem por meio de cultivo com adoção de práticas tradicionais, elaborando técnicas e manejos dos solos, das águas e sementes, flora e fauna que marcam seu espaço, seu território, meio físico e biológico (Pinto et al., 2006; Fidelis, 2011).

Entretanto, o uso da terra pelos quilombolas encontra-se ameaçado seja pela expropriação de suas terras, bem como pela ausência de políticas públicas (Pinto et al., 2014), especialmente aquelas ligadas à inclusão produtiva (p.ex. assistência técnica, crédito, etc.), o que tem impedido a sustentabilidade dos Quilombos do Brasil, já que os recursos oriundos das atividades produtivas não são suficientes para prover tais comunidades de qualidade de vida (Itaborahy, 2012).

Deve-se ter em mente que a melhora da renda econômica quilombola não deve reivindicar o desenvolvimentismo e o produtivismo que condenam a terra a produzir exaustivamente, exaurindo os solos, os biomas e modos de vida (Nahum, 2011), mas sim, um 
sistema de produção agroecológica de alimentos, pautado no processamento e na comercialização direta destes produtos, com vistas a garantir uma melhoria considerável na dieta alimentar, bem como, na soberania alimentar desse segmento (Altieri \& Toledo, 2011; Altieri et al., 2012; Niedele et al., 2013).

Nesse contexto, a manutenção/melhoria da qualidade do solo merece atenção especial, pois trata-se do elo mais importante entre as práticas agrícolas e a sustentabilidade (Stefanoski, 2013). Portanto, o uso e o manejo agrícola adequado do solo é condição sine qua non para estabelecer sistemas sustentáveis de cultivo (Perusi \& Al Zaher, 2012; Rampi et al., 2012, Wendel et al., 2012). A produção orgânica, o plantio direto e os sistemas agroflorestais, tecnologias conservacionistas pautadas na ausência de preparo do solo e na cobertura permanente do terreno por meio de rotação de culturas, constituem manejos que se adaptados podem ser usadas na agricultura familiar como práticas racionais de manejo do solo (Figueiredo et al., 2008; Steiner et al., 2011; Carmo et al., 2012; Gazolla et al., 2015).

Contudo, ainda são escassos os estudos dos solos em Quilombos do Brasil, o que dificulta associar aos saberes e fazeres tradicionais quilombolas, os conhecimentos técnicocientíficos necessários para a melhoria de suas iniciativas de trabalho, geração de renda e alimentação saudável (Júnior \& Brito, 2013).

\subsection{Objetivo Geral}

Avaliar a aptidão agrícola das terras do Quilombo Mesquita - GO e estudar o impacto dos usos das terras na qualidade do solo e na dinâmica da matéria orgânica.

\subsection{Objetivos Específicos}

Analisar o uso e ocupação das terras do Quilombo Mesquita (GO), em relação à aptidão agrícola, bem como caracterizar e classificar os Latossolos da área; 
$\checkmark$ Verificar o impacto nos atributos do solo devido a diferentes usos de um Latossolo Vermelho da região do Cerrado de Goiás, realizados por agricultores familiares quilombolas.

Avaliar as frações lábeis e estáveis da matéria orgânica do solo (MOS) e os índices de labilidade (IL) e de manejo de carbono (IMC) em áreas de diferentes usos da terra no Quilombo Mesquita, em Goiás.

Estudar as formas de $\mathrm{C}$ orgânico e $\mathrm{N}$ nas frações granulométricas da matéria orgânica de um Latossolo Vermelho distrófico típico sob diferentes usos do solo.

\subsection{Hipóteses}

Hp1: as terras manejadas no Quilombo Mesquita estão utilizadas aquém de suas aptidões agrícolas, indicando a necessidade de um plano de manejo para a área.

$\checkmark \mathrm{Hp2}$ : os atributos físicos, químicos e biológicos dos solos são afetados pela mudança de uso da terra.

$\checkmark$ Hp3: mudanças de uso da terra comprometem a dinâmica da matéria orgânica do solo.

\section{REVISÃO BIBLIOGRÁFICA}

\subsection{O Cerrado Goiano}

O Cerrado é o segundo maior bioma brasileiro, ocupando 23,9\% do território nacional, com uma área aproximada de $2.036 .448 \mathrm{~km}^{2}$ (Aguiar et al. 2004). Este bioma situase em sua maioria na região central do Brasil, ocupando grande parte dos estados de Minas Gerais, Tocantins, Goiás, Distrito Federal, Maranhão, Piauí, Mato Grosso, Mato Grosso do Sul e Bahia. Além disso, abrange áreas disjuntas no extremo norte do Pará, uma pequena porção do Amapá, Roraima e Rondônia, uma faixa central do estado de São Paulo e uma porção do Paraná (IBGE, 2016). 
O clima predominante é o Tropical Sazonal, de inverno seco, com temperatura média anual de $22,5^{\circ} \mathrm{C}$ e médias mensais muito variáveis. A precipitação média varia de 1200 a $1800 \mathrm{~mm}$ (IBGE, 2016), com chuvas concentradas de setembro a abril, chovendo mais próximo da Amazônia e menos próximo à Caatinga. No restante do ano, passa por períodos secos, onde praticamente não chove (Lima, 2011), com a umidade relativa variando entre 10\% a 30\% (Brasil, 2009). O bioma também é responsável por abrigar nascentes de oito das doze grandes bacias hidrográficas brasileiras (Durigan, 2010; Lima, 2011).

Para Ribeiro \& Walter (2008), esse Bioma abrange um mosaico diversificado de vegetação, incluindo desde fisionomias campestres, savânicas e até florestais, como as matas secas e as matas de galeria. Assim, o Bioma do Cerrado ora se manifesta como campo sujo, ora como cerradão, ora como campo cerrado, ora como cerrado sensu stricto ou campo limpo. Desta forma, quando se percorre esse Bioma, em poucos quilômetros podem-se encontrar estas diferentes fisionomias.

Para Sano et al. (2008) essa diversificação da vegetação é determinado pelo mosaico de manchas de solo com gradiente de fertilidade, pela irregularidade dos regimes hídricos e características das queimadas de cada local (frequência, época, intensidade) e pela ação antrópica.

Os solos dominantes no Cerrado são, em sua maioria, classificados como Latossolos (45,7\%), além de Neossolos Quartzarênicos (15,2\%), Podzólicos (15,1\%) e Plintossolos $(9,0 \%)$, representando $85 \%$ do total da área do Bioma, sendo os demais classificados como Litossolos (Camargo et al., 1987; Gomes et al., 2004). Dentre esses, merece atenção especial os Latossolos por predominarem nesse Bioma, sendo caracterizados, principalmente, pela baixa fertilidade e alta acidez. Por outro lado, trata-se de solos antigos, profundos, com ótima drenagem, bem estruturados, alta estabilidade de agregados e 
permeabilidade, boa aeração, baixa resistência à penetração e que se assentam em relevos planos ou levemente ondulados (Kluthcouski et al., 2003; Evangelista, 2011).

As características desses solos aliadas ao avanço tecnológico (a partir da década de 70) foram capazes de ocasionar a expansão agrícola na região do Cerrado. Assim, é possível corrigir a acidez e a baixa fertilidade com o uso adequado de corretivos e de fertilizantes. Além disso, por serem bem drenados, resistentes à compactação e ocuparem relevos planos, são solos fisicamente favoráveis à mecanização quando bem manejados. Desta forma, com a calagem e a adubação, os cerrados tornaram-se a grande área de expansão agrícola do Brasil.

Mesmo com tamanha importância, o Cerrado já perdeu 48,46\% de sua vegetação nativa (IBGE, 2004) e, ainda, vem sofrendo com a alta taxa de desflorestamento (Rezende et al., 2006; Rufini et al., 2010 ).

Em Goiás, o bioma Cerrado ocupa 97\% da área total do estado, considerando as diferentes variações fisionômicas encontradas no estado (campo, campo rupestre, campo cerrado, cerrado Sensu Stricto, cerradão e vereda) (Ferreira et al., 2005).

Para Bonelli (2001), a expansão da agricultura e o uso de tecnologias modernas no Cerrado geraram benefícios socioeconômicos inegáveis, tais como o aumento da oferta dos produtos agrícolas, tanto para uso doméstico como para exportação, ganhos na produtividade da agricultura, diversificação das economias locais, aumento da renda de municípios e melhorias sociais em várias localidades.

Vale destacar que, a agricultura patronal, de larga escala com forte característica exportadora, foi ocupando espaços cada vez maiores, levando a se pensar que a agricultura familiar seria gradativamente eliminada do estado de Goiás. Porém, isso não ocorreu, pois, segundo dados do MMA (2016), muitas populações sobrevivem de seus recursos naturais, incluindo etnias indígenas, quilombolas, geraizeiros, ribeirinhos, babaçueiras, vazanteiros, 
dentre outros agricultores familiares, que juntos, fazem parte do patrimônio histórico e cultural brasileiro, e detêm um conhecimento tradicional da biodiversidade do Cerrado. No entanto, esses tipos de agricultores têm diminuído, tendo em vista o processo acelerado de expulsão do campo devido à sua modernização e à concentração fundiária.

Todavia, a sobrevivência dessas comunidades familiares é importante, pois pode viabilizar a transição para uma agricultura mais sustentável (Darolt, 2000; Silva, 2007), em função da diversificação de culturas, maiores possibilidades de adequação aos ecossistemas locais considerando os conhecimentos dos produtores, formas de produção e uso de tecnologias endógenas, com maior emprego de mão-de-obra. Ademais, para Monego et al. (2013), o modelo agrícola brasileiro tem nos estabelecimentos de agricultura familiar os responsáveis por $70 \%$ da produção de alimentos no País, razão pela qual são importantes aliados no desenvolvimento local sustentável, na geração de renda/emprego, na redução do êxodo rural e na promoção da segurança alimentar e nutricional.

Deve-se ter em vista que a agricultura tradicional e a agricultura convencional podem coexistir. Há muitas evidências de práticas sustentáveis e virtuosas (por exemplo, plantio direto, integração lavoura pecuária, etc.) no âmbito da agricultura convencional e do agronegócio e que não deveriam ser condenadas, já que respeitam os princípios e são consistentes com os objetivos mais amplos do desenvolvimento sustentável.

Klink \& Machado (2005) citam que um dos principais desafios para a conservação do Bioma Cerrado será demonstrar a importância que a biodiversidade desempenha no funcionamento dos ecossistemas. O conhecimento sobre a biodiversidade e as implicações das alterações no uso da terra sobre o funcionamento dos ecossistemas serão fundamentais para o debate "desenvolvimento versus conservação".

Assim, a sustentabilidade do Cerrado envolve aspectos gerenciais e tecnológicos, sendo que a primeira etapa desse processo se baseia no planejamento da ocupação da área, a 
começar pela determinação da aptidão agrícola das terras, visando orientar sua destinação e o nível tecnológico exigido, para que seu uso seja racional. Com isso, todas as ações devem ser previamente planejadas para permanecerem equilibradas e harmônicas, ou seja, devem ser economicamente viável, socialmente responsável e ambientalmente sustentável.

\subsection{Os Quilombos no Brasil}

A escravidão, também conhecida como escravismo ou escravatura, foi a forma de relação social de produção adotada no Brasil, desde o período colonial até pouco antes do final do Império (Seyferth, 2002; Marquese, 2006). A escravidão no País foi marcada principalmente pela exploração da mão de obra de negros trazidos da África e transformados em escravos no Brasil (Schmitt, 2002), para extração de recursos naturais (na sua maioria madeira, ouro e prata), bem como para sustentar o sistema de plantation, pautado na monocultura (principalmente de cana de açúcar) (Furtado, 2005; Santos, 2012). Durante mais de três séculos a construção da nação brasileira se deu com base no trabalho escravo (Melo, 2011).

As estimativas sobre o total de escravos trazidos para a América e, especialmente, para o Brasil variam muito. Para toda a América, entre os séculos XVI e XIX, os cálculos vão de 10 a 20 milhões de escravos (Thorne, 2004). Para Souza (2008), a escravidão contabilizou nas Américas cerca de 15 milhões de africanos, homens e mulheres. Segundo Florentino et al. (2004), as estimativas em torno dos escravos traficados para o Brasil giram em torno de três milhões e meio de africanos. De acordo com Reis \& Gomes (2000), cerca de $40 \%$ dos africanos escravizados vieram para o Brasil. Diante desses vultosos números, nenhuma região do Brasil tinha menos de $27 \%$ de escravos em sua população (Moura, 1993).

Os negros foram usados como mão de obra nos engenhos de cana-de-açúcar (Bahia e Pernambuco), nas fazendas de café (Sudeste), na mineração - na extração de ouro e diamante - (Minas Gerais, Goiás), na criação de gado (Sul do país), bem como eram 
obrigados a construir e reparar cercas, cavar fossos, consertar estradas e pontes, prover a casagrande de lenha, reparar os barcos e os carros de boi, pastorear o gado, cuidar do pomar e das criações dos senhores. E, também tinham que providenciar parte do seu próprio alimento caçando, pescando ou cuidando da própria roça (Albuquerque \& Filho, 2006).

Diante das condições precárias que viviam e dos trabalhos extenuantes a que eram submetidos os escravos, nas diferentes regiões do país, onde havia trabalho escravo, deu-se início a inúmeras revoltas (Marquese, 2006; Andrade, 2009). Para Souza (2008), Melo (2011), Santos (2012) e Haeter et al. (2013) esse processo em que africanas e africanos e seus descendentes eram forçados a perder a sua condição de sujeitos, que lhes atribuía valor de troca e que lhes tratava como mercadorias já nasceu acompanhado de expressivas formas de resistência. A formação de quilombos, sem dúvida, foi a mais radical das formas de resistência escrava, contribuindo decisivamente para a ruína do sistema escravista brasileiro.

Os quilombos se formaram em quase todo o Brasil, tendo em vista que onde houve escravidão existiu quilombo (Silva \& Nascimento, 2012). Além dos quilombos constituídos no período da escravidão, muitos foram formados após a abolição formal da escravatura, pois continuaram a ser, para muitos, a única possibilidade de viver em liberdade (Haeter et al., 2013). Constituir um quilombo tornou-se um imperativo de sobrevivência, posto que a Lei Áurea deixou os negros e negras abandonados à própria sorte.

De acordo com Melo (2011), cada quilombo possuía uma formação específica, ou seja, surgiam não somente pela fuga de escravos, mas também foram formados a partir da constituição de núcleos de famílias negras que viviam em terras abandonadas por senhores/fazendeiros, outros em terras doadas aos negros e também em terras doadas a santos que os negros cultuavam. Houve ainda casos de formação de quilombos em locais em que negros (escravos ou ex-escravos) conseguiram arrecadar capital para comprar terras. Para Nascimento (2011), nos quilombos ainda podiam viver negros e negras já libertos, índios, não 
negros que não tinham espaço na sociedade branca e patriarcal, ou seja, os quilombos eram espaços em que se encontravam pessoas que por vários motivos não tinham espaço na sociedade branca.

Assim, a formação dos quilombos surgiu e se perpetua até hoje na realidade brasileira, passando por várias transformações ao longo do tempo (O’dwyer, 2002; Haeter et al., 2013). Dados da Fundação Cultura Palmares (FCP, 2016) revelam que foram certificadas como descendentes de africanos escravizados duas mil oitocentos e quarenta e nove comunidades, das quais 6,0\% ( $\mathrm{n}=172)$ na Região Sul; 12,1\% ( $\mathrm{n}=345)$ na Região Norte; $14,1 \%(n=402)$ na Região Sudeste; 63,4\% (n= 1.804) na Região Nordeste e 4,4\% (n=126) na Região Centro-Oeste. Segundo dados da Coordenação Nacional de Articulação das Comunidades Negras Rurais Quilombolas (CONAQ, 2016), estima-se que existam 4 milhões de famílias quilombolas espalhadas pelo Brasil.

\subsubsection{A dificuldade do acesso a terra e demais direitos}

Antes mesmo da abolição da escravidão, o Estado brasileiro não proporcionou aos quilombolas o devido acesso a direitos essenciais, especialmente aquele ligado à segurança territorial (Leite, 2000; Maestri, 2005; Haerter et al., 2013). Pouco antes da abolição foi editada a Lei de Terras de 1850, com o objetivo de regular a forma pela qual as pessoas poderiam ter a propriedade das terras no Brasil, assim ficou condicionando a obtenção da propriedade da terra exclusivamente à compra e venda, impedindo que muitas pessoas com pouco ou nenhum recurso financeiro pudessem adquirir uma terra ou regularizar a posse que exercia (Mendes, 2009). Num cenário em que se percebia a possibilidade de abolição da escravidão essa foi uma forma de evitar que negros e negras, entre outros tantos grupos sociais marginalizados, tivessem acesso seguro à terra (Souza, 2008; Melo, 2011; Santos, 2012). 
Todavia, o grande marco das políticas quilombolas no Brasil foi construído a partir dos Atos das Disposições Constitucionais Transitórias (ADCT), sendo posteriormente incorporada à Constituição Federal de 1988. No artigo 68 é definido então o direito dos quilombolas às terras que viviam "Aos remanescentes das comunidades dos quilombos que estejam ocupando suas terras é reconhecida a propriedade definitiva, devendo o Estado emitir-lhes os títulos respectivos.". Para Leite (2000), a terra, evidentemente, é crucial para a continuidade do grupo, do destino dado ao modo coletivo de vida destas populações.

Esse marco legal é de grande importância, pois foi o único dispositivo nacional que depois da escravidão contemplou a população ex-escrava, após um século de esquecimento e de exclusão (Haeter et al., 2013; Marques \& Gomes, 2013). No âmbito internacional, há a Convenção $\mathrm{n}^{\circ} 169$, sobre povos indígenas e tribais, adotada na $76^{\mathrm{a}}$ Conferência Internacional do Trabalho. Promovida pela Organização Internacional do Trabalho (OIT) em 1989, ela constitui o primeiro instrumento internacional vinculante que trata especificamente dos direitos dos povos indígenas e tribais (Courtis, 2009).

Mesmo que a Constituição tenha trazido legalmente apontamentos para direitos sociais aos negros, isso não significou que tais direitos passaram imediatamente a ser colocados em prática, pois a primeira titulação de terra quilombola se deu em novembro de 1995, ou seja, sete anos após a promulgação da Constituição/88 (Trecanni, 2006; Silva \& Cezar, 2014).

Todavia, apenas com a promulgação da Constituição Federal de 1988, cem anos após a abolição formal e inconclusa da escravidão, as comunidades quilombolas brasileiras tiveram o direito ao território reconhecido em lei (Haeter et al., 2013; Carvalho \& Lima, 2013). Nessa ocasião, foi feita uma revisão da história da escravidão e da sua abolição levando a descoberta do que até então era ignorado pelo Estado: muitas comunidades de 
remanescentes de quilombos haviam se formado no território brasileiro . Assim, a definição normativa do conceito de quilombo passa a ser de acordo com o Decreto $\mathrm{n}^{\circ} 4.887 / 2003$ :

“Art. 2. Consideram-se remanescentes das comunidades dos quilombos, para os fins deste Decreto, os grupos étnico-raciais, segundo critérios de auto atribuição, com trajetória histórica própria, dotados de relações territoriais específicas, com presunção de ancestralidade negra relacionada com a resistência à opressão histórica sofrida”.

O mesmo Decreto acima é o que "Regulamenta o procedimento para identificação, reconhecimento, delimitação, demarcação e titulação das terras ocupadas por remanescentes das comunidades dos quilombos de que trata o art. 68 do Ato das Disposições Constitucionais Transitórias", ficando o Instituto Nacional de Colonização e Reforma Agrária (INCRA) como o órgão responsável pela política de regularização fundiária e titulação das terras quilombolas.

O procedimento de regularização fundiária realizado pelo INCRA possui inúmeras etapas, tornando longo e burocrático a titulação de terras, e, é por isso que dos anos de 2005 a maio de 2016, o Instituto titulou trinta comunidades quilombolas, tendo iniciado trabalho de regularização em mais de trezentos processos (INCRA, 2016).

Ademais, os quilombolas possuem sua base de sustentação econômica, em atividades agrícolas, extrativistas, mercantis, mineradores, pastoris e serviços. Apesar da multifuncionalidade presente nos Quilombos, de acordo com o relatório divulgado pelo Ministério do Desenvolvimento Social (MDS), realizado por Pinto et al. (2014), muitas comunidades tradicionais brasileiras localizadas em áreas de difícil acesso ainda vivem em situação de risco. O relatório revela que 55,6\% dos adultos residentes em comunidades quilombolas vivem com fome ou sob o risco de inanição. A mesma realidade, embora em 
números um pouco menores, se reproduz na população infantil, na qual 41,1\% das crianças e adolescentes quilombolas está sob esta condição. O cenário de fome não é o único problema. A pesquisa, realizada em 97 áreas, em 2011, revela grande vulnerabilidade social em outros índices como o acesso à água encanada, presente em menos da metade de domicílios, saúde e educação.

Percebe-se que os quilombolas estão carentes de tecnologia e infraestrutura necessárias para o desenvolvimento em termos de riqueza e bem-estar para as comunidades. Nesse sentido, o setor agrícola mostra-se essencial, pois, além de ser a base da produção de alimentos, é a atividade econômica principal do Brasil. Para Conway \& Toenniessen (2003), em estudo sobre a agricultura de "sobrevivência" na África, as tecnologias agrícolas (bases do processo de inovação e altamente dependentes da extensão e assistência técnica e de acesso a crédito) têm um papel fundamental na segurança alimentar e no desenvolvimento rural. Para esses autores, a soberania alimentar pode ser alcançada por meio de políticas públicas que invistam em assistência técnica e crédito, voltados para o manejo da fertilidade do solo, bem como o uso de variedades adaptadas.

\subsubsection{A Comunidade Quilombola de Mesquita}

Os registros históricos apontam que, no sertão goiano, na então capitania de Goyaz, os quilombos começaram a se formar em meados de 1727, como afirma Karasch (1996), servindo de mão de obra na atividade de mineração. O município de Luziânia, antiga cidade de Santa Luzia, faz parte dos depósitos auríferos de morfologia irregular em metassedimentos detríticos (Lacerda, 1990), representados por lavras antigas, na Mina do Morro do Ouro (Hagemann 1988, Hagemann et al. 1988, Zini et al 1988). Por isso, a região tem sua origem na mineração do ouro, que motivou a colonização das terras centrais do Brasil, com mão de obra pautada no trabalho escravo. 
De acordo com o Relatório Técnico de Identificação e Delimitação (RTID/INCRA, 2011), o município de Luziânia que se originou de um povoado chamando Santa Luzia, criado com a penetração no estado de Goiás, por volta do ano de 1746, de caravanas portuguesas em busca de ouro e de outros minérios. As abundantes minas, além de vales férteis às margens do Rio Vermelho atraiam grandes contingentes de pessoas vindas de diversas regiões do país. Para Anjos (2006) e Ribeiro (2014), em 1763, durante o período áureo da exploração das minas de ouro, a antiga Santa Luzia chegou a ter 16.529 habitantes, dos quais 12.900 eram escravos.

Porém, no final do século XVIII, inicia-se o declínio atividade minerária, momento no qual, em alqueires doados por um português a três escravas forma-se o Quilombo Mesquita, há mais de 200 anos (Bertan, 2000; Silva, 2003; Ribeiro, 2014). Daí surgiu a Comunidade, onde os quilombolas plantavam para sua subsistência e vendiam os excedentes na atual cidade de Luziânia. Assim, os quilombolas de Mesquita cultivaram suas tradições e costumes e tinham no marmelo e na marmelada produzida artesanalmente, há mais de um século, a tradicional fonte de boa parte dos recursos externos (RTID/INCRA, 2011).

A Comunidade Quilombola de Mesquita está localizada no Município de Cidade Ocidental, no estado de Goiás, na região Centro-Oeste do Brasil, entorno do Distrito Federal, região metropolitana de Brasília, distante cerca de 60 km da Capital Federal. A Comunidade foi auto reconhecida como remanescente de comunidade quilombola pela Fundação Cultural Palmares (FCP) em 2004. Em 2009, a comunidade reivindicou a regularização fundiária do seu território, tendo o INCRA publicado, em 2010, o relatório técnico de identificação e delimitação do território (RTID) quilombola. O RTID identificou a presença de 785 famílias, sendo que muitas famílias emigraram do território por falta de terras. O relatório em questão delimitou como Território Quilombola de Mesquita uma área de 4.292,8259 ha, sendo que desta área total apenas 761,257 ha está sob posse dos quilombolas. 
Segundo o RTID/INCRA (2011), 84,74\% das terras manejadas pelos quilombolas de Mesquita enquadram-se na classe III do sistema de classificação da capacidade de uso da terra, com solos limitados pela baixa fertilidade e seca edafológica (5-6 meses do ano). Todavia são terras próprias tanto para lavouras (culturas anuais e perenes) como para pastagens.

Assim, diante das características das terras do Quilombo Mesquita, é possível efetuar um manejo conservacionista da área além de suprir as necessidades ambientais. Segundo Almeida et al. (2008) e Franandes et al. (2008), dentro das diretrizes do manejo conservacionista, o cultivo agrícola se dá pela indispensável implantação de rotação de culturas, com o uso de plantas de cobertura, com o mínimo de revolvimento do solo, visando o maior acúmulo de matéria orgânica sobre o solo, mantendo ou melhorando a sua qualidade.

\subsection{Qualidade do solo}

Devido o solo ser um importante componente relacionado, dentre outras funções, à produção de biomassa, fornecendo suporte mecânico, água e nutrientes às culturas agrícolas, para Chaer e Tótola (2007), a conservação ou a melhoria da sua qualidade é vital para a sustentação da atividade agrícola no mundo. É por isso que nos últimos anos a preocupação com a qualidade do solo tem crescido, na medida em que seu uso e mobilização intensiva podem diminuir a sua capacidade de manter uma produção biológica sustentável (Carvalho et al., 2004). Assim, é recomendável o monitoramento dos solos sob diferentes sistemas de manejo para a preservação da sua qualidade para que o mesmo possa proporcionar uma produtividade sustentável (Fialho et al., 2008).

A qualidade do solo é o vínculo mais importante entre o sistema de produção e a sustentabilidade agrícola, sendo essa última conceituada como a capacidade de um sistema agrícola produzir alimentos e fibras sem comprometer as condições que viabilizam esse processo de produção (Gliessman, 2000). Assim, a sustentabilidade está fundamentada em 
cinco pilares: produtividade, segurança, proteção, viabilidade e aceitabilidade (Smyth \& Dumanski, 1995). A relação entre qualidade do solo e sustentabilidade agrícola consiste na produção de alimentos e fibras em um solo capaz de cumprir suas funções, num processo de produção ambientalmente seguro, economicamente viável e socialmente aceito (Vezzani \& Mielniczuk, 2009).

A avaliação da qualidade dos solos é um fator importante, visto que está ligado diretamente à qualidade ambiental. Segundo Doran \& Park (1994), a qualidade do solo é definida como, a capacidade de um tipo específico de solo funcionar dentro dos ecossistemas naturais ou manejados para sustentar a produtividade biológica, manter a qualidade ambiental e promover saúde de plantas e animais.

Uma das mais eficientes formas de mensurar a qualidade do solo e seus efeitos para o meio ambiente é por meio dos indicadores de qualidade do solo, que são atributos que podem ser monitorados em observações de campo, amostragem, sensoriamento remoto, por compilações de dados pré-existentes ou por combinações desses métodos (Arshad \& Martin, 2002).

No entanto, a quantificação da qualidade do solo é uma tarefa ainda árdua e passa pela adoção do método adequado, qualitativo ou quantitativo, que considere e possa transformar a natureza complexa e especifica de cada tipo de solo em atributos mensuráveis, para refletir o real estado de funcionar, possibilitando avaliações sistemáticas independentes de seus múltiplos usos (Karlen et al., 1997). A dificuldade em definir padrões de qualidade do solo decorre do fato da enorme variabilidade das características (física, química e biológica) intrínsecas dos solos, bem como de fatores externos, como as interações dos solos com o ecossistema, práticas de uso e manejo, e de prioridades socioeconômicas e políticas, dentre outras. (Doran \& Park, 1998; Sojka \& Upchurch, 1999). 
Nortcliff (2002) sugere uma proposta resumida baseada em definir explicitamente as funções que determinam a qualidade do solo, identificar os atributos de cada função e, então, selecionar um conjunto mínimo de indicadores físicos, químicos e biológicos, sensíveis ao manejo e de fácil determinação que, acompanhados ao longo do tempo, são capazes de detectar as alterações da qualidade do solo em função do uso e das práticas de manejo do solo.

\subsubsection{Indicadores de qualidade do solo}

Indicador pode ser entendido como um instrumento que permite a avaliação de um sistema e, que determina o nível que esse sistema deve ser mantido para que seja sustentável. São utilizados comumente com objetivo de definir ou estabelecer padrões de sustentabilidade e inferir sobre uma dada realidade com consequente auxílio na tomada de decisão (Beaudoux, 1993; Nortcliff, 2002). Um indicador pode ser uma variável mensurável, um processo, ou uma construção complexa de variáveis múltiplas, como um índice, que inclui inúmeras medidas do solo, tais como densidade, uniformidade de agregados, matéria orgânica e outros (Vezzanii \& Mielniczuk, 2009; Araújo et al., 2012).

Os indicadores da qualidade do solo podem ser classificados, de um modo geral, em quatro grupos; visuais, físicos, químicos e biológicos. Embora esta divisão em grupos seja usual, é importante salientar que estes atributos e processos, em sua maioria, são interrelacionados. Os melhores indicadores da qualidade do solo são aqueles que integram os efeitos combinados de diversos atributos ou processos do solo, os quais devem ser precisos, simples para o uso, ou seja, devem estar associados à função para a qual se pretende usar o solo (Tótola \& Chaer, 2002).

Nesse contexto, os indicadores visuais de qualidade do solo podem ser obtidos de observações ou de interpretação de fotografias. Assim, incluem a avaliação visual de características do solo pelos agricultores (p.ex. declividade, mudança de cor, presença de 
minhocas, presença de ervas daninhas, perdas do solo por erosão, capacidade de armazenamento de água, condições de plantio, crescimento de plantas, dentre outros) (Niero et al., 2010).

Os indicadores físicos são relacionados ao arranjo das partículas sólidas e dos poros, tais como densidade, textura, estrutura, etc. (Mota et al., 2011). De modo geral, com o aumento da intensidade de cultivo tem sido observada alteração no tamanho dos agregados, aumento da densidade, redução da porosidade total e aumento da resistência à penetração (Mota et al., 2010, Moreira et al., 2012; Stefanoski et al.; 2013).

Os indicadores químicos são medições de pH, matéria orgânica, salinidade, disponibilidade de nutrientes, capacidade de troca de cátions, fósforo, potássio, etc. (Carneiro et al., 2009). Dentre os principais indicadores químicos de qualidade do solo destaca-se a matéria orgânica do solo (MOS) em virtude de ser altamente suscetível a alteração frente às práticas de manejo (Reinert et al., 2006), além de estabelecer relação com as demais propriedades do solo, tais como a densidade, a porosidade, a superfície específica, a agregação e a retenção de água. Carneiro et al. (2009) e Laurente et al. (2011) verificaram que os atributos químicos mostraram pequena variação entre as áreas sob diferentes manejos e uso do solo, porém, diferiram na maioria das variáveis quando comparados com a área nativa (Cerrado).

Indicadores biológicos representam diferentes aspectos da qualidade do solo nos diferentes ecossistemas (Elliott, 1997) e podem ser utilizados para monitorar três funções ou parâmetros básicos: agregação das partículas do solo, estoque de nutrientes e atividade biológica (Gregorich et al., 1994). Os principais indicadores biológicos são a biomassa microbiana, a mineralização de nutrientes (N, S e P), respiração do solos e atividade enzimática (Araújo \& Monteiro, 2007). As propriedades microbiológicas têm sido amplamente discutidas na literatura como indicadores de qualidade (Paradelo et al., 2009; 
Stursová et al., 2011; Zhang et al., 2011; Lisboa et al., 2013) dado o relacionamento entre atividade e diversidade microbiana, vegetação e sustentabilidade dos ecossistemas (Doran et al., 1996).

Goedert (2005) propôs um conjunto mínimo da qualidade do solo (Tabela 1), no qual os níveis de sustentabilidade são quantificados a partir dos atributos mais frequentemente avaliados em pesquisas científicas envolvendo a qualidade dos solos brasileiros.

Tabela 1. Proposta de conjunto de indicadores ou atributos mínimos para avaliar a qualidade do solo sob uso agrícola e de seus valores mínimos ou níveis de sustentabilidade, determinados na camada superficial de Latossolos argilosos tropicais.

\begin{tabular}{|c|c|}
\hline Indicador ou Atributo & Valores ou nível de sustentabilidade \\
\hline Densidade do solo (Ds) & $<1 \mathrm{~g} \mathrm{~cm}^{-3}$ \\
\hline Porosidade total $(\mathrm{Pt})$ & $>0,6 \mathrm{~cm}^{3} \mathrm{~cm}^{-3}$ \\
\hline \multicolumn{2}{|l|}{ Resistencia mecânica à penetração (Rp) } \\
\hline Grau de floculação (Gf) & $\begin{array}{c}<1,0 \mathrm{Mpa} \\
>50 \%\end{array}$ \\
\hline Teor de Matéria Orgânica (MO) & $\begin{array}{l}\text { Textura argilosa: > } 40 \mathrm{~g} \mathrm{~kg}^{-1} \\
\text { Textura média: }>30 \mathrm{~g} \mathrm{~kg}^{-1} \\
\text { Textura arenosa: }>20 \mathrm{~g} \mathrm{~kg}^{-1}\end{array}$ \\
\hline Capacidade de troca catiônica (CTC) & $\begin{array}{l}\text { Textura argilosa: }>10 \mathrm{cmol}_{\mathrm{c}} \mathrm{dm}^{-3} \\
\text { Textura média: }>7 \mathrm{cmol}_{\mathrm{c}} \mathrm{dm}^{-3} \\
\text { Textura arenosa: }>4 \mathrm{cmol}_{\mathrm{c}} \mathrm{dm}^{-3}\end{array}$ \\
\hline Saturação por base (V) & $>40 \%$ \\
\hline Carbono da biomassa microbiana (CBM) & $>200 \mathrm{mg} \mathrm{C} \mathrm{kg}^{-1}$ \\
\hline Respiração basal (RB) & $>10 \mathrm{mg} \mathrm{C} \mathrm{kg}^{-1}$ \\
\hline Coeficiente metabólico $\left(\mathrm{q}\left(\mathrm{CO}_{2}\right)\right)$ & $>0,05$ \\
\hline
\end{tabular}

Fonte: Goedert (2005).

Segundo o Goedert (2005), os atributos de natureza física listados são adequados para avaliar o estado de agregação e compactação e, como consequência, estimar a capacidade 
de infiltração de água no solo. Os de natureza química se destinam a estimar o potencial de disponibilização de nutrientes e, os de natureza biológica refletem a dimensão da atividade microbiana no solo. Em 2013, Lopes et al. (2013) apresentaram os limites máximos e mínimos de vários indicadores microbiológicos para Latossolos Vermelhos argilosos, em condição de Cerrado (Tabela 2).

Tabela 2. Interpretação de classes de indicadores microbianos em um Latossolo Vermelho distrófico da região de Cerrado, na profundidade de $0-10 \mathrm{~cm}$.

\begin{tabular}{|c|c|c|c|}
\hline \multirow{2}{*}{ Indicador microbiológico } & \multicolumn{3}{|c|}{ Classes de interpretação } \\
\hline & Baixo & Moderado & Adequado \\
\hline $\mathrm{C}$ da biomassa microbiana $\left(\mathrm{mg} \mathrm{C} \mathrm{kg}^{-1}\right)$ & $\leq 215$ & $216-375$ & $>375$ \\
\hline Respiração basal (mg C kg $\left.{ }^{-1}\right)$ & $\leq 40$ & $41-90$ & $>90$ \\
\hline Celulase (mg glucose $\mathrm{kg}^{-1}$ soil d $\mathrm{d}^{-1}$ ) & $\leq 70$ & $71-105$ & $>105$ \\
\hline$\beta$ glucosidase (mg p-nitrophenol kg ${ }^{-1}$ soil $\mathrm{h}^{-1}$ ) & $\leq 65$ & $66-115$ & $>115$ \\
\hline Fosfatase ácida (mg p-nitrophenol kg ${ }^{-1}$ soil h$^{-1}$ ) & $\leq 680$ & $681-1160$ & $>1160$ \\
\hline Arilsulfatase (mg p-nitrophenol $\mathrm{kg}^{-1}$ soil $\mathrm{h}^{-1}$ ) & $\leq 40$ & $41-90$ & $>90$ \\
\hline
\end{tabular}

Fonte: Lopes et al. (2013).

\subsection{A matéria orgânica do solo}

A matéria orgânica do solo (MOS) é resultado da decomposição parcial, síntese e re-síntese de resíduos da biota, principalmente resíduos vegetais (Silva \& Resck, 1997), e abrange todos os compostos de carbono orgânico, incluindo microrganismos vivos ou mortos, em diversos estágios de decomposição. Segundo Stevenson \& Cole (1999), a MOS é constituída basicamente por $\mathrm{C}, \mathrm{H}, \mathrm{N}, \mathrm{S}$ e $\mathrm{P}$, sendo que o C compreende cerca de $58 \%$ da MOS.

Apesar de encontrar-se em torno de 1 a $5 \%$ na maioria dos solos agrícolas, a matéria orgânica (MOS) exerce importante função na manutenção da qualidade e fertilidade do solo, uma vez que influencia os principais processos físicos (aeração, maior retenção e armazenamento de água), químicos (fornecimento de nutrientes para as plantas e na maior 
capacidade de troca catiônica do solo), e, biológicos (ambiente adequado ao estabelecimento e à atividade da microbiota) do solo (Brady, 1989; Chan et al., 2002; Glatzela et al., 2003; Pillon et al., 2007).

As frações orgânicas do solo podem ser arbitrariamente estabelecidas com base em critérios de localização, composição química ou grau de estabilidade do material orgânico (Baldock \& Nelson, 2000). Vários modelos têm sido descritos com o objetivo de separar os diversos componentes da MOS (Duxbury et al., 1989; Woomer et al., 1994). Para Diekow (2003) as frações da MOS podem ser divididas em três grupos: a) com base sua localização (particulada, associada a minerais, dissolvida, inerte e biomassa microbiana; b) com base na sua composição química (substâncias húmicas); e c) com base no seu grau de estabilidade.

A matéria orgânica leve ou MOP, também chamada de fração lábil compreende cerca de 10-30\% do carbono orgânico total (COT) do solo e é constituída por resíduos de plantas recém-adicionados ao solo, em diferentes estágios de decomposição (Cambardella \& Elliot, 1992). Esta fração apresenta alta taxa de decomposição e curto período de permanência no solo (Wolf \& Snyder, 2003). Sua principal função do ponto de vista agronômico é fornecer nutrientes às plantas por meio do processo de mineralização, promovido pelos organismos do solo (Resende et al., 2007) ou, do ponto de vista ecológico, servir como base da cadeia alimentar dos organismos do solo.

O termo húmus é usado de forma generalizada para designar substâncias não húmicas e húmicas presentes no solo. As substâncias não húmicas são grupos de compostos orgânicos bem definidos (proteínas e aminoácidos, carboidratos simples e complexos, resinas, ligninas, lipídeos, ácidos orgânicos, ácidos nucleicos entre outros) e representam de 10 a 15\% da reserva total do carbono orgânico nos solos minerais (Camargoet al., 1999).

As substâncias húmicas constituem a maior parte do COT nos solos, de 85 a 90\%, apresentando alta reatividade e interação com as superfícies minerais e espécies químicas em 
solução (Moreira \& Siqueira, 2006). A alta reatividade é explicada pelo enriquecimento em grupos funcionais contendo oxigênio na forma de carboxilas, hidroxilas fenólicas e carbonilas (Sargentini Júnior et al., 2001; Portugal et al., 2008). Além disso, são relativamente mais estáveis e recalcitrantes no ambiente, comparativamente às substâncias não húmicas (Stevenson, 1994), podendo permanecer no solo por séculos ou até milênios (Khan, 1972).

Por causa da complexidade de seus componentes, a identificação dos compartimentos ou frações da MOS é de grande importância para o entendimento de sua dinâmica em determinado sistema. Essa identificação pode auxiliar na formulação de estratégias que preservem a MOS e viabilizem sistemas produtivos mais sustentáveis (Mendonça, 2007; Cereta et al., 2008, Figueiredo et al., 2010; Fontana et al., 2011; Carmo et al., 2012; Costa et al., 2013; Gazolla et al., 2015). De maneira geral, as técnicas de fracionamento são do tipo químico, empregado para avaliar os teores de $\mathrm{C}$ nas diferentes frações húmicas presentes no solo, e, do tipo físico, relacionado a matéria orgânica particulada, que se baseia na localização da MOS ao longo do perfil.

\subsubsection{Dinâmica da matéria orgânica em solos do Cerrado}

A matéria orgânica é um componente chave, determinante para as propriedades físicas, químicas e biológicas, particularmente, em solos intemperizados, com argilas de baixa atividade, como é o caso dos Latossolos, que abrangem 95 milhões de hectares do Cerrado, aproximadamente, 46\% a 48\% da área total (Rein \& Duxbury, 2008). Para Zinn et al. (2005), nos Latossolos, diversos trabalhos tem mostrado que a principal fonte de cargas negativas é a MOS, associadas às frações silte e argila.

A manutenção da MOS em quantidade e qualidade desejável está relacionada diretamente com a qualidade dos compostos de carbono aportados, das condições climáticas e das propriedades do solo (Loss et al., 2012; Rossi et al., 2012; Winck et al., 2014). Condições 
de clima quente e úmido, típicas de regiões tropicais, apresentam, de modo geral, maior susceptibilidade à perda de carbono, como é o caso do Estado de Goiás, cujo 97\% do território é ocupado por área de Cerrado.

Assim, as mudanças no sistema de uso da terra, como a substituição de sistemas naturais em áreas agrícolas com cultivo mais intensivo, o frequente uso de queimadas e o preparo intensivo do solo promove o rápido declínio dos teores de matéria orgânica do solo (MOS) (Silva \& Mendonça, 2007, Santos et al., 2011, Carmo et al., 2012; Winck et al., 2014) e contribui significativamente para o aumento da concentração de gases do efeito estufa (GEE) na atmosfera (Souza et al., 2012), principalmente o dióxido de carbono $\left(\mathrm{CO}_{2}\right)$, o óxido nitroso $\left(\mathrm{N}_{2} \mathrm{O}\right)$ e o metano $\left(\mathrm{CH}_{4}\right)($ Cerri et al., 2007).

A maioria dos estudos concentra-se no $\mathrm{C}$ orgânico total (COT) e $\mathrm{N}$ total (NT), todavia, pequenas alterações nos totais de $\mathrm{C}$ e $\mathrm{N}$ são dificilmente detectáveis em curto prazo, em parte porque a variabilidade natural do solo é elevada (Silva et al., 2011). Alguns estudos têm demonstrado que determinados compartimentos da MOS são capazes de detectar mais rapidamente, as mudanças nos conteúdos de C no solo associadas ao manejo (Loss et al., 2010; Xavier et al., 2006). Um dos principais indicadores das alterações no solo, provocadas pelos diferentes sistemas de manejo é o teor de C orgânico do solo total (COT) ou particulado (COP). Alguns autores têm demonstrado que o COP é mais sensível às mudanças promovidas pelos sistemas de manejo na dinâmica do C do solo (Conceição et al., 2005; Souza et al., 2008; Xavier et al., 2006). Souza et al. (2008), avaliando o C orgânico em um sistema de integração lavoura-pecuária submetido a diferentes intensidades de pastejo em plantio direto verificaram que o COP foi o atributo mais sensível em demonstrar variações no C orgânico do solo sob as condições de manejo da pastagem adotadas.

Sendo assim, estudos que visem caracterizar o comportamento e composição da MOS são fundamentais para o entendimento de sua natureza e elucidação dos fatores que 
governam sua estabilização, a fim de identificar e estabelecer práticas de manejo mais conservacionistas que contribuam com a sua preservação e promovam a sustentabilidade dos agroecossistemas.

\subsection{Avaliação do potencial agrícola das terras}

A sustentabilidade dos agroecossistemas dos Quilombos do Brasil vem sendo ameaçada pela expropriação das terras e pela ausência de políticas públicas de inclusão produtiva, que têm gerado grandes impactos nas paisagens através do intenso processo de substituição das áreas naturais por diversos tipos de uso do solo e da fragmentação das áreas com cobertura florestal.

A problemática da ocupação da terra é preocupante tanto em áreas quilombolas, como em assentamentos rurais, pois denotam as precárias condições da agricultura familiar nessas áreas, as quais têm sido tema de diversas pesquisas, como as de Silva (2006); Chaves et al. (2010); Silva et al. (2011) e Wadt et al. (2014) e que propõem novos métodos de planejamento, implantação e manutenção de áreas sob agricultura familiar.

No planejamento do uso do solo, os diversos atributos da terra são analisados e avaliados com vistas a um uso ótimo e sustentável. As principais informações requeridas sobre esses atributos são a sua distribuição espacial, os padrões (forma e arranjo das unidades de recursos) e o tipo de recurso. A análise dos padrões atuais de uso do solo e dos fatores econômicos e sociais que afetam o uso do solo também são importantes no processo de planejamento (Boher, 2000).

Em termos de avaliação do potencial das terras, apesar da existência de diversos sistemas, no Brasil os mais adotados são: o sistema de avaliação da aptidão agrícola das terras (Ramalho-Filho \& Beek, 1995) e o sistema de capacidade de uso (Marques, 1971; Lepsch et al., 1991). Na presente tese, optou-se pelo método de Avaliação da Aptidão Agrícola devido a 
algumas vantagens, como: a) maior utilização ao nível nacional; b) considera, na sua estrutura, diferentes níveis de manejo; c) permite modificações, ajustes ou incorporações de outros parâmetros e fatores de limitação, acompanhando assim os avanços do conhecimento ou exigência do nível de estudo; d) aceita adaptações e aplicações em diferentes escalas de mapeamento; e) considera a viabilidade de redução de limitações, pelo uso de capital e tecnologia, distinguindo o pequeno e o grande agricultor.

Ademais, trabalhos como os de Hamada et al. (2006), Reshmidevi et al. (2009). Silva et al. (2010), Wadt et al. (2014), dentre outros, empregam o sistema de Avaliação da Aptidão Agrícola das terras, elaborado por Ramalho Filho \& Beek (1995) para avaliação de terras no Brasil, nos mais variados níveis de detalhe e adaptações. Muitos desses estudos têm sido realizados utilizando-se sistemas de informações geográficas (SIG), entre os quais destacam-se, com resultados bastante promissores na avaliação da aptidão agrícola das terras, os trabalhos de Pedron et al. (2006); Chaves et al. (2010); Barros et al. (2004); Silva et al. (2010); e na avaliação de terras por meio de sistemas especialistas, segundo método da FAO os de Bacic (1998) e Chagas et al. (2006).

\subsubsection{Sistema de Avaliação da Aptidão Agrícola das Terras}

A avaliação da aptidão objetiva orientar o uso mais adequado das terras pela identificação de suas limitações e o modo que tais limitações restringem a aptidão/capacidade de uso, resultando no diagnóstico sobre a melhor forma de utilizá-la, inclusive com indicação de práticas agrícolas recomendadas para o seu melhoramento (Hashim et al., 2002; Resende et al., 2007).

Esta metodologia teve sua primeira versão proposta por Bennema et al. (1965) para a interpretação de levantamentos de solos, com o intuito de tornar acessível uma interpretação prática das características dos solos para avaliações do potencial de uso agrícola. 
Esse sistema foi atualizado posteriormente, tendo sua última versão publicada por Ramalho Filho e Beek (1995).

Segundo Resende et al. (2007), esse sistema considera um modelo de solo ideal, sem deficiência de fertilidade, água ou oxigênio além da ausência de suscetibilidade à erosão e impedimentos ao uso de mecanização. Nessa metodologia são considerados três diferentes níveis de manejo das terras de acordo com a disponibilidade de recursos para a produção agrícola, sendo estes:

a) Manejo primitivo (Nível A): o produtor não utiliza nenhum tipo de recurso que seja adquirido fora da propriedade, utilizando somente o esforço braçal ou tração animal para o cultivo, sem a utilização de adubação ou correção do solo;

b) Manejo intermediário (Nível B): há um investimento para a produção, utilizando-se adubações com macronutrientes, técnicas simples de conservação do solo, sementes melhoradas e preparo do solo com aração e gradagem;

c) Manejo avançado (Nível C): há um grande investimento na produção, com utilização de técnicas mais sofisticadas de conservação do solo, utilização de sementes de ótima qualidade, adubações com macro e micronutrientes e mecanização em diversas etapas do processo de produção.

Considera seis grupos de aptidão, que constituem os distintos sistemas de cultivo ou uso: a) Grupo 1, 2 e 3: lavouras anuais e perenes; b) Grupo 4: pastagem plantada; c) Grupo 5: silvicultura e, ou, pastagem natural; d) Grupo 6: áreas que devem ser destinadas à preservação da flora e fauna.

A avaliação da aptidão agrícola é feita a partir da análise de fatores limitantes, quais sejam: deficiência de fertilidade, deficiência de água, deficiência de oxigênio ou excesso de água, suscetibilidade à erosão e impedimentos à mecanização; sendo atribuídos a eles graus de limitação (nulo, ligeiro, moderado, forte ou muito forte, com graus 
intermediários), e ainda em função da possibilidade de melhoramento para todos os fatores limitantes.

Além disso, é a metodologia que propõe viabilidade de melhoramento na determinação dos graus de limitação, de acordo com o nível de manejo empregado. A partir da identificação dos graus de limitação é possível determinar o subgrupo ou classe de aptidão (boa, regular, restrita ou inapta) para cada nível de manejo (A, B ou C), e o grupo (de 1 a 6) é determinado pelo melhor nível de manejo e tipo de uso em que se enquadra o solo.

O sistema de aptidão é usualmente utilizado em trabalhos de zoneamento ecológico econômico seja para a avaliação do uso da terra tanto para culturas específicas, como realizado por Carvalho et al. (2008) que realizaram o zoneamento para cana-de açúcar e eucalipto no estado de Minas Gerais. Silva et al (2010) utilizou o SAAAT associado a um sistema de informação geográfica no estado de Santa Catarina gerando mapas que sobrepostos possibilitaram a identificação de áreas: com uso satisfatório à adequado, sobreutilizadas, subutilizadas e áreas de conflito ambiental. Os autores ressaltam que o uso do sistema de informação geográfica contribui na redução de tempo de trabalho e subjetividade nas avaliações. Esses trabalhos tem demonstrado a possibilidade de uso do sistema de aptidão agrícola.

\subsection{REFERÊNCIAS BIBLIOGRÁFICAS}

AGUIAR, L.M.S., MACHADO, B.M. \& MARINHO-FILHO, J. A Diversidade Biológica do Cerrado. In Cerrado: ecologia e caracterização (L.M.S. Aguiar \& A.J.A Camargo, eds.). Embrapa Cerrados, Planaltina, 2004, p. 17-40.

ALBUQUERQUE, W.; FILHO, W. F. Uma história do negro no Brasil. Centro de Estudos Afro-Orientais; Brasília: Fundação Cultural Palmares, 2006. 
ALTIERI, M. A.; TOLEDO, V. M. The agroecological revolution in Latin America: rescuing nature, ensuring food sovereignty and empowering peasants. The Journal of Peasant Studies, v. 38, n.3, 2011, p. 587-612.

AlTIERI, M.; FUNES-MONZOTTE, F.; PETERSEN, P. Agroecologically eficiente agricultural systems for smallholder farmers: contributions to food sovereignty. Agron. Sustain. Dev., v. 32, 2012, p. 1-13.

ANDRADE, M.P. Novos sujeitos de direitos e seus mediadores - uma reflexão sobre processos de mediação entre quilombolas e aparelhos de Estado. In. Antropolítica: Revista Contemporânea de Antropologia - n. 27, $2^{\circ}$ sem. 2009. 2009, Niterói: EdUFF.

ANJOS, R. S. A. dos. Quilombolas: tradições e cultura da resistência. São Paulo: Aori Comunicação, 2006.

ARAUJO, E.A.; KER, J.C.; NEVES, J.C.L.; LANI, J.L. Qualidade do solo: conceitos, indicadores e avaliação. Revista Brasileira de Tecnologia Aplicada nas Ciências Agrárias, Guarapuava-PR, v.5, n.1, p.187-206, 2012.

ARAÚJO. A.S.F; MONTEIRO, R.T.R. Indicadores biológicos de qualidade do solo. Bioscience Journal, v.23. n.3, p.66-75, 2007

ARSHAD, M. A.; MARTIN, S. Identifying critical limits for soil quality indicators in agroeecosystems. Agriculture, Ecosystems and Environment, Amsterdam, v. 88, p. 153-160, 2002.

BACIC, I. L. Z.; ROSSITER, D. G.; BREGT, A. K. The use of land evaluation information by land use planners and decision-makers: a case study in Santa Catarina, Brazil. Soil Use and Management, United Kingdom, v. 19, n. 2, April. 2003, p. 12-18.

BALDOCK, J.A. \& NELSON, P.N. Soil organic matter. In: SUMNER, M.E., ed. Handbook of soil science. Boca Raton, CRC Press, 2000. p.25-84.

BALDOCK, J.A. \& NELSON, P.N. Soil organic matter. In: SUMNER, M.E., ed. Handbook of soil science. Boca Raton, CRC Press, 2000. p.25-84. 
BARROS, Z. X.; TORNEIRO, M. T. STIPP, N. A. F.; CARDOSO, L. G.; POLlO, R. . Estudo da adequação do uso do solo, no município de Maringá -PR, utilizando-se de geoprocessamento. Engenharia Agrícola, Jaboticabal, v. 24, n. 2, maio/ago. 2004, p.436-444.

BENNEMA, J.; BEEK, K. J.; CAMARGO, M. N. Um sistema de classificação de capacidade de uso da terra para levantamentos de reconhecimento de solos. Rio de Janeiro: Ministério da Agricultura, Divisão de Pedologia e Fertilidade do Solo, 1965. 50p.

BONELLI, R. Impactos econômicos e sociais de longo prazo da expansão agropecuária no Brasil: revolução invisível e inclusão social. Instituto de Pesquisa Econômica Aplicada (IPEA). Textos para discussão 838. 2001, Rio de Janeiro.

BRADY, N.C. Natureza e propriedades dos solos. 7.ed. São Paulo: Freitas Bastos, 1989. $878 \mathrm{p}$.

CAMARGO, M. N.; KLANT, E.; KAUFFMAN, J. H. Sistema Brasileiro de classificação de solos. Boletim Informativo da Sociedade Brasileira de Ciência do Solo, Campinas, v.12, Jan/abr. 1987, p.11-33.

CAMBARDELLA, C.A. \& ELLIOT, E.T. Particulate soil organic matter changes across a grassland cultivation sequence. Soil Sci. Soc. Am. J., 56:777-783, 1992.

CARMO, F. F.; FIGUEIREDO, C. C.; RAMOS, M. L. G.; VIVALDI, L. J.; ARAÚJO, L. G. Frações granulométricas da matéria orgânica em latossolo sob plantio direto com gramineas. Bioscience Journal, Uberlândia, v. 28, n. 3, p. 420-431, 2012.

CARNEIRO, M. A. C.; SOUZA, E. D. DE; REIS, E. F. DOS; PEREIRA, H. S.; AZEVEDO, W. R. de. Atributos físicos, químicos e biológicos de solo de Cerrado sob diferentes sistemas de uso e manejo. Revista Brasileira de Ciência do Solo, v.33, p.147-157, 2009.

CARVAlHO, A.M. de; BUSTAMANTE, M.M. da C.; AlCÂNTARA, F.A. de; RESCK, I.S.; LEMOS, S.S. Characterization by solid-state CPMAS 13C NMR spectroscopy of decomposing plant residues in conventional and no-tillage systems in central Brazil. Soil and Tillage Research, v.102, 2009, p.144-150.

CARVAlHO, L. G. de; MELlO, C. R. de; AlVES, M. de C.; CURI, N.; MARQUES, A. F. S. e M.; CARVALHO, L. M. T. de; MARQUES, J. J. G. Zoneamento da cana-de açúcar e do 
eucalipto: aspectos geofísicos e bióticos. In: SCOLFORO, J. R. S.; OLIVEIRA, A. D. de; TAVARES, L. M. (Org). Zoneamento ecológico-econômico do Estado de Minas Gerais: zoneamentos e cenários exloratórios. Lavras: UFLA, 2008. p. 53-60.

CARVALHO, R. et al. Atributos físicos da qualidade de um solo sob sistema agroflorestal. Pesquisa Agropecuária Brasileira, v. 39, n. 11, 2004, p. 1153-1155.

CARVALHO, R.M.A.; LIMA, G.F.C. Comunidades quilombolas, territorialidade e a legislação no brasil: uma análise histórica. Revista de Ciências Sociais, n. 39, Outubro de 2013, pp. 329-346.

CARVALHO, T.M. \& BAYER, M. Utilização dos produtos da "Shuttle Radar Topography Mission" (SRTM) no mapeamento geomorfológico do Estado de Goiás. Revista Brasileira de Geomorfologia, v. 9, 2008, p. 35-41.

CERRI, C.E.P.; SPAROVEK, G.; BERNOUX, M.; EASTERLING, W.E.; MELILLO, J.M. \& CERRI, C.C. Tropical agriculture and global warming: Impacts and mitigation options. Sci. Agric., 64:83-99, 2007.

CHAER, G. M.; TÓTOLA, M. R. Impacto do manejo de resíduos orgânicos durante a reforma de plantios de eucalipto sobre indicadores de qualidade do solo. Revista Brasileira de Ciência do Solo, v. 31, n. 06, 2007, p. 1381-1396.

CHAGAS, C. S.; CARVALHO JÚNIOR, W.; PEREIRA, N. R.; FERNANDES FILHO, E. I. Aplicação de um sistema automatizado (ALES - Automated Land Evaluation System) na avaliação das terras das microrregiões de Chapecó e Xanxerê, oeste catarinense, para o cultivo de grãos. Revista Brasileira de Ciência do Solo, Viçosa, MG, v. 30, n. 2, mar/abril. 2006,p. 509-522.

CHAVES, A. A.; LACERDA, M. P. C.; KATO, E.; GOEDERT, W. J.; RAMOS, M. L. G. Uso das terras da parte norte da bacia do rio descoberto, Distrito Federal, Brasil. Bragantia, Campinas, v. 69, n. 3, jul/set. 2010, p. 711-718.

CONAQ. Coordenação Nacional das Comunidades Quilombolas. Disponível em http://quilombosconaq.blogspot.com.br/. Acesso em 01 de junho de 2016. 
CONCEIÇÃO, P.C.; AMADO, T.J.C.; MIELNICZUK, J.; SPAGNOLLO, E. Qualidade do solo em sistemas de manejo avaliada pela dinâmica da matéria orgânica e atributos relacionados. Revista Brasileira de Ciência do Solo, v.29, p.777-788, 2005.

CONWAY, G.; TOENNIESSEN, G. Agriculture. Science for African food security. Science. 2003 Feb 21; 299(5610):1187-8.

COSTA, E.M.; SILVA, H.F.; RIBEIRO, R.A. Matéria orgânica do solo e o seu papel na manutenção e produtividade dos sistemas agrícolas. ENCICLOPÉDIA BIOSFERA, Centro Científico Conhecer - Goiânia, v.9, n.17; 2013, p. 1842-1860.

COURTIS, C. Anotações sobre a aplicação da Convenção 169 da OIT sobre povos indígenas por tribunais da América Latina. Sur, Rev. int. direitos human. vol.6 n.10 São Paulo Jun de 2009, p. 52-81.

CUNHA, G. M. et al. Biomassa e estoque de carbono e nutrientes em florestas Montana da Mata Atlântica na região norte do estado do Rio de Janeiro. Revista Brasileira de Ciência do Solo, Campinas, v. 33, 2009, p. 1157-1185.

CUNHA, N. R. S.; LIMA, J. E.; GOMES, M. F. M.; BRAGA, M. J. A intensidade da exploração agropecuária como indicador da degradação ambiental na região dos Cerrados, Brasil. Piracicaba/SP. RER, São Paulo, v. 46, n. 2, 2008, p. 291-323.

DAROLT, M. R. As dimensões da sustentabilidade: um estudo da agricultura orgânica na região metropolitana de Curitiba, Paraná. 2000. Tese (Doutorado em Meio Ambiente e Desenvolvimento).

DORAN, J.W. \& PARKIN, T.B. Defining and assessing soil quality. In: DORAN, J.W.; COLEMAN, D.C.; BEZDICEK, D.F. \& STEWART, B.A., eds. Defining soil quality for a sustainable environment. Madison, SSSA, 1994. p.1-20. (Special, 35).

DORAN, J.W.; SARRANTONIO, M. \& LIEBIG, M.A. Soil health and sustainability. Adv. Agron., 56:1-54, 1996.

DOS ANJOS, R. S. A. Territórios das comunidades remanescentes de antigos uilombos no Brasil - primeira configuração espacial. 3. ed. Brasília: Mapas Editora e Consultoria, 2005. 
DURIGAN, G. O futuro do cerrado mediante o código florestal. Ciencia e Cultura, São Paulo, v. 62, n. 4, out. 2010. Disponível em: Acesso em: 22 jun. 2012.

EVANGELISTA, B. A. Projeção de cenários atuais e futuros de produtividade de cana-deaçúcar em ambiente de Cerrado. 2011. 164f. Tese (Doutorado em Engenharia Agrícola) Universidade Estadual de Campinas, Faculdade de Engenharia Agrícola.

FCP. Fundação Cultural Palmares. Disponível em: http://www.palmares.gov.br/?page_id=37551. Acesso em: 01 de junho de 2016.

FERREIRA, M.E.; MIZIARA, F.; FERREIRA JR., L.G.; RIBEIRO, F.L.; FERREIRA, N.C. Ativos ambientais do bioma cerrado: uma análise da cobertura vegetal nativa e sua relação com o preço da terra no estado Goiás. Revista Brasileira de Cartografia, v. 61, 2009, p. 37-50.

FERREIRA, N.C.; BARCELOS, R.; FERREIRA, L.G. Transferência de informações ambientais geograficamente referenciadas no estado de Goiás: Subsídio à gestão territorial e ambiental integrada e democrática. In. Anais XII Simpósio Brasileiro de Sensoriamento Remoto, Goiânia, Brasil, 16-21 abril, INPE. 2005, p.2137-2144.

FIALHO, J. S.; GOMES, V.F.F.; OLIVEIRA, T.S.; SILVA JUNIOR,J.M.T.S. Indicadores da qualidade do solo, em sistema de rotação, na Chapada do Apodi, Ceará. Revista Ciência Agronômica, v. 39, n. 03, p. 353-361, 2008.

FIDELIS, L. Quilombos, agricultura tradicional e a agroecologia: o agroecossistema do quilombo João Surá sob a ótica da sustentabilidade. CADERNOS CERU, série 2, v. 22, n. 1, junho de 2011, p. 57-72.

FIDELIS, L.M; BERGAMASCO, S.M.P.P. Quilombos e a agroecologia: a agricultura tradicional como estratégia de resistência da comunidade quilombola João Surá. Revista Eletrônica da Associação dos Geógrafos Brasileiros. Seção Três Lagoas/MS, n ${ }^{\circ}$, Ano 10, 2013, p. 112-141.

FIGUEIREDO, C. C.; RESCK, D. V. S.; CARNEIRO, M. A. C. Frações lábeis e estáveis da matéria orgânica do solo sob sistemas de manejo e cerrado nativo. Revista Brasileira de Ciência do Solo, Viçosa, v. 34, n. 3, p. 907-916, 2010. 
FLORENTINO, M.; RIBEIRO, A.V.; SILVA, D.D. Aspectos comparativos do tráfico de africanos para o Brasil (séculos XVIII e XIX) Afro-Ásia, 31 (2004), 83-126.

FONTANA, A.; SILVA, C.F.; PEREIRA, M.G.; LOSS, A.; BRITO, R.J.B.; BENITES, V.M. Avaliação dos compartimentos da matéria orgânica em área de Mata Atlântica. Acta Scientiarum. Agronomy Maringá, v. 33, n. 3, p. 545-550, 2011. DOI: 10.4025/actasciagron.v.33i3.5169, 2011.

FURTADO, C. Formação econômica do Brasil. Companhia Editora Nacional, $32^{\circ}$ ed. 2005.

GAZOLLA, P.R.; GUARESCHI, R.F.; PERIN, A.; PEREIRA, M.G.; ROSSI, C.Q. Frações da matéria orgânica do solo sob pastagem, sistema plantio direto e integração lavourapecuária. Semina: Ciências Agrárias, Londrina, v. 36, n. 2, p. 693-704, mar./abr. 2015.

GLIESSMAN, S. R. Agroecologia: processos ecológicos em agricultura sustentável. Trad. Maria José Guazzelli. Porto Alegre, UFRGS, 2000. 653p.

GOEDERT, W. J. Qualidade do solo em sistemas de produção agrícola. In: CONGRESSO BRASILEIRO DE CIÊNCIA DO SOLO, 30., Recife, 2005. Anais... Recife: SBCS, 2005. 1 CD-ROM.

GOMES, B. V.; CURI, N,; MOTTA,P. E. F.; KER, J. C.; MARQUES, J. J. G. S. M.; SCHULZE, D. G. Análise de componentes principais de atributos físicos, químicos e mineralógicos de solos do bioma cerrado. Revista Brasileira de Ciência do Solo, Viçosa, v.28, n.1, 2004, p. 137-153.

GREGORICH, E.G.; CARTER, M.R.; ANGERS, D.A.; MONREAL, C.M. \& ELLERT, B.H. Towards a minimum data set to assess soil organic matter quality in agricultural soils. Can. J. Soil Sci., 74:367-385, 1994.

HAETER, L.; NUNES, G.H.L.; CUNHA, D.T.R. Refletindo acerca da contribuição da cultura quilombola aos currículos da educação básica brasileira, através da presença da história da África e Afrobrasileira. Identidade!| São Leopoldo, v.18 n. 3, ed. esp., 2013, p. 267-278.

HAMADA, E. ASSAD, M. L. L.; PEREIRA, D. A. Aptidão agrícola na área de recarda do Aquífero Guarani: caso da microbacia hidrográfica do Córrego do Espraiado, Ribeirão Preto, SP. Engenharia Ambiental, Espírito Santo do Pinhal, v. 3, n. 1, jan/jun. 2006, p.62-71. 
HASHIM, I. H.; JAYA, N. S.; GUNAWAN, I. Evaluation of land suitability for selected land utilization types using geographic information system technology. Jurnal Manajemen Hutan Tropika, Bogor, v. 8, n. 2, p. 12-26, Aug. 2002.

IBGE. Instituto Brasileiro de Geografia e Estatística. Disponível em: http://www.ibge.gov.br/home/. Acesso em 01 Jun de 2016.

INCRA. Instituto Nacional de Colonização e Reforma Agrária. Disponível em http://www.incra.gov.br/quilombola. Acesso em 01 de junho de 2016.

INSTITUTO BRASILEIRO DE GEOGRÁFIA E ESTATÍSTICA. Mapa de biomas e de vegetação. 2004. Disponível em: Acesso em: 1 maio 2016.

ITABORAHY, N. Z. Conflitos e Resistências Territoriais na Comunidade Quilombola de São Pedro de Cima: Primeiras Impressões. In: Anais eletrônicos do XXI Encontro Nacional de Geografia Agrária. 15 a 19 de outubro de 2012. Uberlândia-MG.

JÚNIOR, V.C.; BRITO, I.P.F.S. Fortalecimento da agricultura familiar como instrumento para o desenvolvimento rural do território de vitória da conquista - Bahia. Revista Extensão \& Cidadania Vitória da Conquista v. 1, n. 1, jan./jun. 2013, p. 121- 141.

KARASCH, M. Quilombos do ouro na Capitania de Goiás. In: REIS, J. J.; GOMES, F. S. (Orgs.). Liberdade por um fio: história dos quilombos no Brasil. São Paulo: Companhia das Letras, 1996.

KLINK, C. A.; MACHADO, R. B. (2005) A conservação do Cerrado brasileiro. Belo Horizonte, Megadiversidade, v. 1, n. 1, jul. 2005, p. 148-155.

KLUTHCOUSKI, J.; STONE, L. F.; ADAIR, H. Integração lavoura - pecuária. Santo Antônio de Goiás: Embrapa Arroz e Feijão, 2003. 570 p.

LAGO, W.N.M.; LACERDA, M.P.C.; NEUMAMM, M.R.B.; BORGES, T.D. Ocupação e adequação do uso das terras na microbacia do Ribeirão Extrema, Distrito Federal - Parte I. Revista Brasileira de Engenharia Agrícola e Ambiental v.16, n.3, 2012, p.289-296.

LEITE, Ilka Boaventura. "Os quilombos no Brasil: questões conceituais e normativas". Etnográfica, v. IV, n. 2, p. 333-354, 2000. 
LEPSCH, I. F. Manual para levantamento utilitário do meio físico e classificação de terras no sistema de capacidade de uso. Campinas: SBCS, 1991. 175p.

LIMA, J. E. F. W. Situação e perspectivas sobre as águas do cerrado. Ciência e Cultura, São Paulo, jul. 2011 v. 63, n. 3.

LISBOA, F .J. G;, CHAER, G. M.; JESUS, E. C.; FARIA, S. M.; GONÇALVES, F. S.; SANTOS, F. M.; CASTILHO, A. F.; BERBARA, R. L. L. The influence of litter quality on the relationship between vegetation and below-ground compartments: a Procrustean approach. Plant and Soil, v. 367, p. 551-562, 2013.

LOPES, A. A. de C. et al. Interpretation of microbial soil indicators as a function of crop yield and organic carbon. Soil Science Society of America Journal, New York, v. 77, n. 2, p. 461 472, 2013.

LOSS, A., PEREIRA, M. G., PERIN, A., COUTINHO, F. S., CUNHA, L. H. C. Particulate organic matter in soil under different management systems in the Brazilian Cerrado. Soil Research, v.50, 2012, p.685-693.

LOSS, A.; MORAES, A.G.L.; PEREIRA, M.G.; SILVA, E.M.R.; ANJOS, L.H.C. Carbono, matéria orgânica leve e frações oxidáveis do carbono orgânico sob diferentes sistemas de produção orgânica. Comunicata Scientiae, v.1, 2010, p.57-64.

LUCENA, C.S.S.; LIMA, F.E.S.; PEREIRA, C.S. A agricultura familiar na comunidade quilombola do Pêga, em Portalegre - RN. GEOTemas, Pau dos Ferros, Rio Grande do Norte, Brasil, v.6, n.1, 2016, p.51-66.

MAESTRI, M. "Terra e liberdade: as comunidades autônomas de trabalhadores escravizados no Brasil." In: AMARO, Luiz Carlos [Org.]. Afro-brasileiros: história e realidade. Porto Alegre: EST, 2005.

MARQUES, C.E.; GOMES, L. A Constituição de 1988 e a ressignificação dos quilombos contemporâneos Limites e potencialidades. RBCS Vol. 28 nº 81 fevereiro/2013, p. 137-255.

MARQUESE, R. de. B. A DINÂMICA DA ESCRAVIDÃO NO BRASIL: Resistência, tráfico negreiro e alforrias, séculos XVII a XIX. NOVOS ESTUDOS 74, Março de 2006. 
MELO, P. B. de. Quilombos: transição da condição de escravizado à de camponês livre. Revista da ABPN. v. 1, n. 3 - nov. 2010 - fev. 2011, p. 53-76.

MENDES, J.S.R. Desígnios da lei de terras: imigração, escravismo e propriedade fundiária no Brasil Império. CADERNO CRH, Salvador, v. 22, n. 55, 2009, p. 173-184.

MONEGO, E. T.; ALEXANDRE, V. P.; SOUSA, L. M.; MARTINS, K. A.; ROSA, J. Q. S.; SOUZA, P. L. C. de; ASSIS, J. N. de. Produção e potencial agrícolas de alimentos destinados à alimentação escolar em Goiás e no Distrito Federal, na Região Centro-Oeste do Brasil. Rev. Nutr., Campinas, mar./abr., 2013, 26(2):233-241.

MOREIRA, F.M. de S.; SIQUEIRA, J.O. Microbiologia e Bioquímica do Solo. 2.ed. atual. e ampl. Lavras: Ufla, 2006. 729p.

MOREIRA, W. H.; BETIOLI JÚNIOR, E.; PETEAN, L. P.; TORMENA, A. C.; ALVES, S. J.; COSTA, M. A. T.; FRANCO, H. H. S. Atributos físicos de um Latossolo Vermelho distroférrico em sistema de integração lavoura-pecuária. Revista Brasileira de Ciência do Solo, v.36, p.389-400, 2012.

MOTA, M.S.; CREMON, C.; MAPELI, N.C.; SILVA, W.M.; MAGALHÃES, W.A.; CREMON, T. Qualidade e atributos físicos de um Latossolo Vermelho Distroférrico típico em diferentes sistemas de manejo. Dourados, v.4, n.12, p.105-112, 2011.

MOURA, C. Quilombos. Resistência ao escravismo. São Paulo: Ed. Ática, 1993 (3ªed.).

NAHUM, J.S. De Ribeirinha a Quilombola: dinâmica territorial de comunidades rurais na Amazônia paraense. CAMPO TERRITÓRIO: revista de geografia agrária, v. 6, n. 12, ago., 2011 p. $79-103$.

NASCIMENTO, P. C. F. do. Reconstrução de um povo chamado quilombola: análise da dinâmica cultural do Quilombo do Campinho, Paraty/RJ. Monografia apresentada ao curso de Graduação em Produção Cultural da Universidade Federal Fluminense, 2011.

NIEDERLE, MURIEL, CARMIT SEGAL, AND LISE VESTERLUND, "How Costly is Diversity? Affirmative Action in Light of Gender Differences in Competitiveness" Management Science, 2013, Vol 59, No. 1, 1-16. 
NIERO, L.A.C.; DECHEN, S.C.F.; COELHO, R.M.; MARIA, J.C. Avaliações visuais como índi ce de qualidade do solo e sua validação por análises físicas e químicas em um Latossolo Vermelho distroférrico com usos e manejos distintos. Revista Brasileira de Ciência do Solo, Viçosa, v. 34, n. 4, p. 1271-1282, 2010.

NORTCLIFF, S. Standardisation of soil quality attributes. Agric. Ecosyst. Environ., 88:161$168,2002$.

O’DWYER, Eliane Cantarino (org.). Quilombos: identidade étnica e territorialidade. Rio de Janeiro: Editora FGV, 2002. p. 43-82.

PARADELO, R.; MOLDES, A. B.; BARRAL, M. T. Properties of slate mining wastes incubated with grape marc compost under laboratory conditions. Waste Management, v. 29, p. 579-584, 2009.

PEDRON, F. de A. POElKing, E. L.; DALMOLIN, R. S. D.; AZEVEDO, A. C. de; KLANT, E. A aptidão de uso da terra como base para o planejamento da utilização dos recursos naturais no município de São João do Polêsine - RS. Ciência Rural, Santa Maria, v. 36, n.1, jan/fev. 2006p. 105-112.

PERUSI, M.C.; AL ZAHER, C. Preparo conservacionista do solo no contexto da agricultura familiar, estudo de caso na microbacia do córrego fundo, município de Ourinhos/SP. São Paulo, UNESP, Geociências, v. 31, n. 4, 2012, p. 638-649.

PILLON, C.N.; SCIVITTARO, W.B.; POTES, M.L.P.; MORAES, C.S.; MICHELS, G.H.; PEREIRA, J.S. Acúmulo de carbono orgânico por sistemas de cultura sob plantio direto em terras baixas. Cadernos de Agroecologia, v.2, n.1, 2007, p.1040-1043.

PINTO, A.R; BORGES, J.C.; NOVO, M.P.; PIRES, P.S. Quilombos do Brasil: segurança alimentar e nutricional em territórios titulados. Cadernos de Estudos - Desenvolvimento Social em Debate. $\mathrm{n}^{\circ}$ 20, 2014. ISSN 1808-0758.

PINTO, E. P. P.; AMOROSO. M. C. M.; FURLAN. A. Conhecimento popular sobre plantas medicinais em comunidades rurais de mata atlântica - Itacaré, BA, Brasil. Acta Botanica Brasilica, Rio de Janeiro, v. 20, n. 4, 2006, p. 751-762. 
PORTUGAL, A.F.; JUCKSH, I.; SCHAEFER, C.E.G.R.; WENDLING, B. Determinação de estoques totais de carbono e nitrogênio e suas frações em sis- temas agrícolas implantados em Argissolo Vermelho -Amarelo. Revista Brasileira de Ciência do Solo, Viçosa, MG, v. 32, n. 5, 2008, p. 2091-2100.

RAMALHO FILHO, A.; BEEK, K. J. Sistema de avaliação da aptidão agrícola das terras. 3.ed. Rio de Janeiro: EMBRAPA, 1995. 65p.

RAMALHO FILHO, A.; BEEK, K.J. Sistema de avaliação da aptidão agrícola das terras. 3.ed. Rio de Janeiro, Empresa Brasileira de Pesquisa Agropecuária, 1995. 65p.

RAMPI, L.; TAVARES FILHO, J.; BEHLAU,F.; ROMANO, P. Determinação da capacidade de uso do solo visando o manejo sustentável para uma média propriedade em Londrina - PR. Biosci. J., Uberlândia, v. 28, n. 2, Mar./Apr. 2012, p. 251-264.

REATTO, A.; MARTINS, E.S. Classes de solos em relação aos controles da paisagem do bioma Cerrado. In: SCARIOT, A.; SOUZA-SILVA, J.C.; FELFINI, J.M. Cerrado: ecologia, biodiversidade e conservação. 1.ed. Brasília-DF: Ministério do Meio Ambiente, 2005, p.4759.

REIN, T.A. \& DUXBURY, J.D. Modeling the soil organic carbon, texture and mineralogy relations in the profile of Oxisols from the Brazilian Cerrado. In: SIMPÓSIO NACIONAL SOBRE O CERRADO, 9., Brasília, 2008. Anais... Brasília, Embrapa, 2008. CD-ROM.

REINERT, D. J.; REICHERT, D. J.; VEIGA, M.; SUZUKI, L. E. A. S. Qualidade física dos solos. In: Reunião Brasileira de Manejo e Conservação do Solo e da Água, 16, 2006. Aracaju, Resumos... Aracaju: SBCS, 2006. CD-Rom

REIS, J. J.; GOMES, F.S. Introdução - uma história da liberdade. In: REIS, J.J. e GOMES, F. S.(orgs.). Liberdade por um fio: História dos Quilombos no Brasil. São Paulo: Companhia das Letras, 2000, p. 9-25.

RESENDE, M.; CURI, N.; REZENDE, S. B. de; CORRÊA, G. G. Pedologia: base para distinção de ambientes, 5.ed. Lavras:UFLA, 2007. 322 p. 
RESHMIDEVI, T. V.; ELDHO, T. I ; JANA, R. A. GIS-integrated fuzzy rule-based inference system for land suitability evaluation in agricultural watersheds. Agricultural Systems, Netherlands, v. 101, n. 1/2, Jun. 2009, p.101-109.

REZENDE, A. V. et al. Comparison of mathematical models to volume, biomass and carbon stock estimation of the woody vegetation of a Cerrado Sensu Stricto in Brasília, DF. Scientia Forestalis, Piracicaba, v. 71, 2006, p. 65-76.

RIBEIRO, A.S.S. Saberes tradicionais e educação ambiental: encontros e desencontros no Quilombo de Mesquita- Goiás. 2014. 284p. Tese de doutorado.

RIBEIRO, J.F. \& WALTER, B.M.T. As principais fitofisionomias do Bioma Cerrado. In Cerrado: ecologia e flora (S.M. Sano, S.P. Almeida \& J.F. Ribeiro, eds.). Embrapa Cerrados, Planaltina. 2008, p.151 -212.

ROSSI, C. Q.; PEREIRA, M. G.; GIÁCOMO, S. G.; BETTA, M.; POLIDORO, J. C. Frações lábeis da matéria orgânica em sistema de cultivo com palha de braquiária e sorgo. Revista Ciência Agronômica, Fortaleza, v.43, n.1, 2012, p.38-46.

RTID/INCRA - Relatório Técnico de Identificação e Delimitação do Quilombo Mesquita. INCRA: Instituto Nacional de Colonização de Reforma Agrária. Publicado no Diário Oficial da União (DOU) de 29 e 30/08/2011.

RUFINI, A. L. et al. Equações volumétricas para o cerrado Sensu Stricto, em Minas Gerais. Cerne, Lavras v. 16, n. 1, jan./mar. 2010, p. 1-11.

SANO. S. M.; ALMEIDA, S. P.; RIBEIRO, J. F. Cerrado: ecologia e flora. Embrapa Cerrados. Brasília: Embrapa Informação Tecnológica, 2008. 2v. 1279 p.

SANTOS, A. V. Os efeitos de sentidos nos dizeres de professores soteropolitanos sobre a Lei 10.639/03. Dissertação de mestrado, 2012.

SANTOS, A. V. Os efeitos de sentidos nos dizeres de professores soteropolitanos sobre a Lei 10.639/03. Dissertação de mestrado, 2012.

SANTOS, N.Z.; DIECKOW, J.; BAYER, C.;MOLIN, R.; FAVARETTO, N.; PAULETTI, V. \& PIVA, J.T. Forages, cover crops and related shoot and root additions in no-till rotations to C sequestration in a subtropical Ferralsol. Soil Till. Res., 2011, 111:208-218. 
SARGENTINI JUNIOR., E.; ROCHA, J. C.; ROSA, A. H.; ZARA, L.F.; SANTOS, A. Substâncias húmicas aquáticas: fracionamento molecular e caracterização de rearranjos internos após complexação com íons metálicos. Química Nova, v.24, 2001, p.339-344.

SCHMITT, A.; TURATTI, M.C.M.; CARVALHO, M.C.P. A atualização do conceito de quilombo: identidade e território nas definições teóricas. Ambiente \& Sociedade - Ano V - N. 10, 2002, p. 1-6.

SEYFERTH, G. Colonização, imigração e a questão racial no Brasil. REVISTA USP, São Paulo, n.53, março/maio 2002, p. 117-149.

SILVA, A.S.; SILVA, I.F.; SILVA NETO, L.F. \& SOUZA, C. Semeadura direta na produção do milho em agricultura de sequeiro na região nordeste do Brasil. Ci. Rural, 2011. 41:15561562.

SILVA, E. B. da; NOGUEIRA, R. M.; UBERTI, A. A. A. Avaliação da aptidão agrícola das terras como subsídio ao assentamento de famílias rurais, utilizando sistemas de informação geográfica. Revista Brasileira de Ciência do Solo, Viçosa, MG, v. 34, n. 6, nov/dez. 2010, p. 1977-1990.

SILVA, F. M.; SOUZA, Z. M. de; FIGUEIREDO, C. A. P. de; MARQUES JÚNIOR, J.; MACHADO, R. V. Variabilidade espacial de atributos químicos e de produtividade na cultura do café. Ciência Rural [online], v.37(2), 2007, p. 401-407.

SILVA, I.R.; MENDONÇA, E.S. Matéria orgânica do solo. In: NOVAIS, R.F.; ALVAREZ V., V.H.; BARROS, N.F.; FONTES, R.L.F.; CANTARUTTI, R.B.; NEVES, J.C.L. (eds.) Fertilidade do solo. Viçosa: Sociedade Brasileira de Ciência do Solo, 2007. p.275-374.

SILVA, J. E.; RESCK, D. V. S. Matéria orgânica do solo. In: VARGAS, M. A. T.; HUNGRIA, M. (Ed.) Biologia dos solos dos cerrados. Planaltina: Embrapa-CPAC, 1997. p. 467-524.

SILVA, P.N.; CEZAR, L.S. Análise da política pública de reconhecimento quilombola: o caso da comunidade de conceição do Imbé, RJ. VII Congresso Brasileiro de Geógrafos. 2014.

SILVA, S.R.; NASCIMENTO, L.K.N. Negros e territórios quilombolas no Brasil. Cadernos Cedem, v.3. n.1, 2012, p. 33-37. 
SMYTH, A.J. \& DUMANSKI, J. A framework for evaluating sustainable land management. Can. J. Soil Sci., 75:401-406, 1995.

SOJKA, R.E. \& UPCHURCH, D.R. Reservations regarding the soil quality concept. Soil Sci. Soc. Am. J., 63:1039-1054, 1999.

SOUZA, B. O. Aquilombar-se. Panorama Histórico, Identitário e Político do movimento Quilombola Brasileiro. 204 f. 2008. Dissertação (Mestrado em Antropologia Social) Departamento de Antropologia, Universidade de Brasília, Brasília, 2008.

SOUZA, E.D.; COSTA, S.E.V.G. A.; LIMA, C. V. S.; ANGHINONI, I.; MEURER, E. J.; CARVALHO, P.C.F. Carbono orgânico e fósforo microbiano em sistema de integração agricultura-pecuária submetido a diferentes intensidades de pastejo em plantio direto. Revista Brasileira de Ciência do Solo, v.32, p.1273-1282, 2008.

STEFANOSKI, D.C.; SANTOS, G.G.; MARCHÃO, R.L.; PETTER, F.A.; PACHECO, L.P. Uso e manejo do solo e seus impactos sobre a qualidade física. Revista Brasileira de Engenharia Agrícola e Ambiental, v.17, n.12, 2013, p.1301-1309.

STEVENSON, F.J. \& COLE, M.A. Cycles of soil: Carbon, nitrogen, phosphorus, sulfur, micronutrients. 2.ed. New York, John Wiley \& Sons, 1999. 427p.

STEVENSON, F.J. 1994. Humus chemistry: genesis, composition, reactions. 2. ed. John Willey, New York, USA. 496 pp.

ŠTURSOVÁ, M.; BALDRIAN, P. Effects of soil properties and management on the activity of soil organic matter transforming enzymes and the quantification of soil-bound and free activity. Plant and Soil, v. 338, p. 99-110, 2011.

THORNE, E. "Ethnic and race-based political organization and mobilization". In Mayra Buvinic, Jacqueline Mazza e Ruthanne Deutsch, Social inclusion and economic development in America Latina, Inter-American Development Bank, Latin America: Lessons for Public Policy, 2004, p. 307-331.

TÓTOLA, M. R.; CHAER, G. M. Microrganismos e processos microbiológicos como indicadores da qualidade dos solos. In: CURI, N.; MARQUES, J. J.; GUILHERME, L. R. G.; 
LIMA, J. M.; LOPES, A. S. S.; ALVAREZ V., V. H., (Eds.) Tópicos em Ciência do Solo. Viçosa, MG, Sociedade Brasileira de Ciência do Solo, 2002. V. 02, p. 195-276

TRECCANI, G.D.. Terras de Quilombo: caminhos e entraves do processo de titulação. Belém: Programa Raízes, 2006.

VENDRAME, P.R.S.; BRITO, O.R.; GUIMARÃES, M.F.; MARTINS, E.S.; BECQUER, T. Fertility and acidity status of latossolos (oxisols) under pasture in the Brazilian Cerrado. An Acad Bras Cienc., 2010, p. 1085-1094.

VEZZANI, F. M.; MIELNICZUK, J. UMA VISÃO SOBRE QUALIDADE DO SOLO. R. Bras. Ci. Solo, 33:743-755, 2009.

WADT, P.G.S.; SOUZA, C.B.C.; ANJOS, L.H.C.; PEREIRA, M.G.; SILVA, L.M. Aptidão agrícola das terras aplicadas em pequenos estabelecimentos rurais do sudoeste amazônico. Biota Amazônia, Macapá, v. 4, n. 3, 2014, p. 25-30.

WINK, B.R.; VEZZANI, F.M.; DIECKOW, J.; FAVARETTO, N.; MOLIN, R. Carbono e nitrogênio nas frações granulométricas da matéria orgânica do solo, em sistemas de culturas sob plantio direto. R. Bras. Ci. Solo, 2014, 38:980-989.

WOLF, B.; SNYDER, G.H. Sustainable soils. The place of organic matter in sustaining soils and this productivity. New York: Food Product, 2003. 352p.

WOOMER P.L.; MARTIM, A.; ALBRECHT, A.; RESCK, D.V.S. \& SCHARPENSEEL, H.W. The importance and management of soil organic matter in the tropics. In: WOOMER, P.L. \& SWIFT, M.J., eds. The biological management of tropical soil fertility. Chichester, John Wiley \& Sons, 1994. p.47-80.

XAVIER, F.A.S.; MAIA, S.M.F.; OLIVEIRA, T.S.; MENDONÇA, E.S. Biomassa microbiana e matéria orgânica leve em solos sob sistemas agrícolas orgânico e convencional na Chapada da Ibiapaba - CE. Revista Brasileira de Ciência do Solo, v.30, 2006, p.247-258.

ZHANG, C.; LIU, G.; XUE, S.; SONG, Z. Rhizosphere soil microbial activity under diferente vegetation types on the Loess Plateau, China. Geoderma, v. 161, p. 115-125, 2011.

ZINN, Y.L.; LAL, R. \& RESCK, D.V.S. Texture and organic carbon relations described by a profile pedotransfer function for Brazilian Cerrado soils. Geoderma, 127:168-173, 2005. 


\section{CAPÍTULO 1}

\section{Aptidão agrícola das terras e caracterização de Latossolos do Quilombo Mesquita, GO}

\section{RESUMO}

Os Quilombos do Brasil apresentam particularidades nos seus solos que precisam ser estudadas. O objetivo desse trabalho foi analisar uso e ocupação das terras do Quilombo Mesquita (GO), em relação à aptidão agrícola, utilizando técnicas de geoprocessamento, bem como caracterizar e classificar os Latossolos da área. Quanto à caracterização dos Latossolos, foi selecionado um transecto representativo da distribuição dos solos no Quilombo, onde foram abertas trincheiras no topo (P1) e no terço médio (P2 e P3). Os perfis foram descritos morfologicamente e analisados os seus atributos físicos e químicos dos horizontes A e Bw. A maior parte do Quilombo Mesquita possui aptidão agrícola para lavouras, sendo as terras distribuídas em seis classes de aptidão agrícola nos níveis de manejo A, B e C, representadas pelas classes 2(b)c, 3(a)b, 3(b)c, 4p, 5(n) e 6. Verificou-se que em mais da metade da área do Quilombo é praticada alguma atividade agrícola, seja com culturas anuais ou perenes, e, ou pastagens, havendo muitas áreas com solos expostos, cujo sistema de manejo necessita ser adequado. Boa parte das áreas de uso restrito para pastagem natural (classe 5n) e sem aptidão agrícola (classe 6) estão sendo utilizadas para atividade agrícola. Os Latossolos constituem os solos de maior ocorrência no Quilombo Mesquita, sendo os solos estudados classificados como Latossolo Vemelho distrófico típico - LVd, desenvolvido a partir de material de natureza psamo-pelítica.

Palavras-chave: Rocha pelítica, taxonomia de solos, planejamento agrícola, sistema de informações geográficas. 


\title{
Agricultural potential of the land and characterization of Latosols at Quilombo Mesquita, GO
}

\begin{abstract}
The Quilombos at Brazil shows peculiarities in their soils that need to be studied. The aim of this study was to analyze the agricultural suitability and the use and occupation of the lands of the Quilombo Mesquita, using geoprocessing techniques, and to characterize and classify the Latosols area. As for the characterization of Latosols it was selected a representative transect the distribution of soils in the Quilombo where trenches were opened at the top (P1) and in the middle third (P2 and P3). The profiles were morphologically described and analyzed their physical and chemical properties of horizons A and Bw. Most Quilombo Mesquita has agricultural suitability for crops, and the lands divided into six classes of agricultural suitability in the management areas A, B and C , represented by class 2(b)c, 3(a)b , 3(b)c , 4p, 5(n) and 6. It was found that in more than half of the Quilombo Mesquita area some agricultural activity is practiced, either with annual and perennial crops, and or pastures, with many areas with exposed soil, whose management system it needs to be adequate. Many of the areas restricted to natural grassland (class 5n) and without agricultural potential (class 6) are being used for agriculture. Oxisols are the higher occurrence of soils in Quilombo Mesquita, and the soils classified as Red Latosol typical - LVd developed from psamo-pelitic material nature.
\end{abstract}

Key words: pelitic rock, soil taxonomy, agricultural planning, geographic information system. 


\subsection{INTRODUÇÃO}

O estado de Goiás (GO) apresenta enorme diversidade de solos e relevos, com intensa atividade agrícola, com níveis tecnológicos variáveis, somando-se ainda a sua elevada importância ambiental, por estar quase que totalmente inserido no Bioma Cerrado (Brasil, 2002), sendo dividido em categorias relacionadas aos tipos de vegetação, como: cerradão, cerrado, campo cerrado, campo sujo, campo limpo e mata galeria (Ribeiro \& Walter, 2008). As fitofisionomias apresentam-se, principalmente, relacionadas aos diferentes ambientes pedomorfogeológicos, que resultam da relação de interdependência entre os fatores que condicionam a distribuição dos solos no estado.

Nas áreas de Cerrado podem existir formações geológicas provenientes de rochas sedimentares, metamórficas e ígneas, sendo que as rochas sedimentares ocupam uma área considerável nesse bioma (CPRM/SIC-SGM, 2008). Vale constar que, as formas tabulares de relevo relacionam-se às rochas sedimentares pelíticas e psamíticas de estratificação plana ou ligeiramente inclinadas, caracterizadas sendo conhecidas como rochas pré-intemperizadas na sua gênese sedimentar (Vilella \& Nogueira, 2011), dando origem a solos diversos tais como, Latossolos, Cambissolos, Neossolos, Plintossolos, Argissolos, Nitossolos, dentre outros (Goedert, 1987; Resende et al., 1999; Spera et al., 1999; Lepsch \& Oliveira, 2003).

Todavia, para Oliveira et al. (2003), a capacidade produtiva do setor agrícola de um país, estado ou região depende, fundamentalmente, da disponibilidade e da qualidade do recurso natural solo, constituindo o conhecimento de suas diversas aptidões, fator de grande importância para sua utilização racional na agricultura.

O trabalho elaborado por Hirano et al. (1989) classifica as terras de Goiás segundo o "Sistema de Avaliação da Aptidão Agrícola das Terras", tendo sido identificado que 20,5 milhões de hectares com vocação para lavouras; 3,6 milhões de hectares, para pastagem plantada; 1,5 milhões de hectares para silvicultura e 6,3 milhões de hectares para pastagem 
natural. As terras sem aptidão para uso agrícola, 3,5 milhões de hectares, correspondem a $10,3 \%$ da superfície do estado. Todavia, as terras indicadas para lavouras perfazem $60,4 \%$ do Estado, com aptidão boa ou regular para lavouras, compreendendo Latossolos, Argissolos e Nitossolos.

Os Latossolos apresentam mineralogia da fração argila composta por caulinita, gibbsita, goethita e hematita, variando apenas nas suas proporções, em função do grau elevado de intemperização dos minerais primários. Esses solos são muito evoluídos, sendo encontrados predominantemente na região de planaltos e, em encostas, sustentando uma grande parte da pecuária e da produção agrícola em Goiás e, no Brasil, uma vez que suas propriedades físicas são altamente adequadas para mecanização e produção em larga escala (EMBRAPA, 2013).

Todavia, os Latossolos do estado de Goiás são bastante utilizados por agricultores familiares (Caume, 1997; Tedesco, 2001), que persistem nessas áreas apesar da ausência de infraestrutura e de politicas públicas que fortaleçam esse segmento agrícola no estado. Dentre os produtores de agricultura familiar, há os agricultores familiares descendentes de africanos escravizados, conhecidos como quilombolas, que no estado, fazem parte de trinta e três comunidades quilombolas (FCP, 2016), que habitam a região desde o século XVIII.

Para Matos et al. (2014), os quilombolas construíram um saber regional sobre os solos que possibilitou a sobrevivência desse grupo e de seus descendentes. Pautados no conhecimento prático ao longo de décadas de desenvolvimento de atividade agrícola, com predomínio da mão-de-obra familiar, tipificam os solos em função da facilidade de preparo, da fertilidade natural (vegetação nativa presente), da ocorrência de encrostamento superficial, das taxas de infiltração de água e do grau de permeabilidade. Segundo Mazoyer \& Roudart (2010), isso demonstra o quão importante o solo é para a sobrevivência dos seres vivos no planeta. 
No entanto, pouco se sabe acerca do recurso solo do estado de Goiás, que é o principal substrato de sustentação das atividades agrícolas e para sobrevivência dos agricultores familiares. Poucos são os levantamentos pedológicos realizados no estado, levando ao reduzido conhecimento acerca dos solos da região, seu enquadramento taxonômico e distribuição cartográfica. Ao se tratar de territórios quilombolas, esses levantamentos em escalas adequadas, são inexistentes, por isso, faz-se necessário estudar os solos dos Quilombos do Brasil, já que para Brady \& Weil (2010) e Lepsch (2011), o principal objetivo e utilização de levantamentos de solos tem sido a sua interpretação para uso agrícola, que fornece importantes subsídios que permitem a melhor decisão sobre a utilização do solo de maneira racional e eficiente, tendo em vista que o uso inapropriado da terra conduz à exploração ineficiente e à degradação dos recursos naturais, à pobreza e outros problemas sociais.

Para Ramalho \& Filho (1995), Silva et al. (2010) e Lago et al. (2012), o estabelecimento da aptidão agrícola das terras é um grande instrumento de planejamento para o setor agropecuário, pois quando bem elaborado, permite ao produtor rural tomar a melhor decisão, maximizando seus recursos, aumentando sua rentabilidade, diminuindo desperdícios, além de minimizar a pressão antrópica em ecossistemas que deveriam ser conservados, além de eliminar os riscos de poluição ambiental como excessos de agrotóxicos e corretivos.

O objetivo desse trabalho foi analisar uso e ocupação das terras do Quilombo Mesquita (GO), em relação à aptidão agrícola, bem como caracterizar e classificar os Latossolos da área, a partir de informações da literatura e da caracterização morfológica, física e química dos principais solos aptos para desenvolvimento de atividades agropecuárias. 


\subsection{MATERIAL E MÉTODOS}

\subsubsection{Localização e clima da área de estudo}

O Quilombo de Mesquita localiza-se na região Centro-Oeste do Brasil, no município da Cidade Ocidental (16 $04^{\prime} 40.79^{\prime \prime} \mathrm{S}$ e $\left.47^{\circ} 52^{\prime} 05.51^{\prime \prime} \mathrm{W}\right)$, na região leste do estado de Goiás, entorno do Distrito Federal, região metropolitana de Brasília, distante cerca de $60 \mathrm{~km}$ da Capital Federal, inserida no Cerrado goiano (Figura 1). A área total do Quilombo é de 4.292,8259 ha, sendo que 761,257 ha está sob posse dos quilombolas.

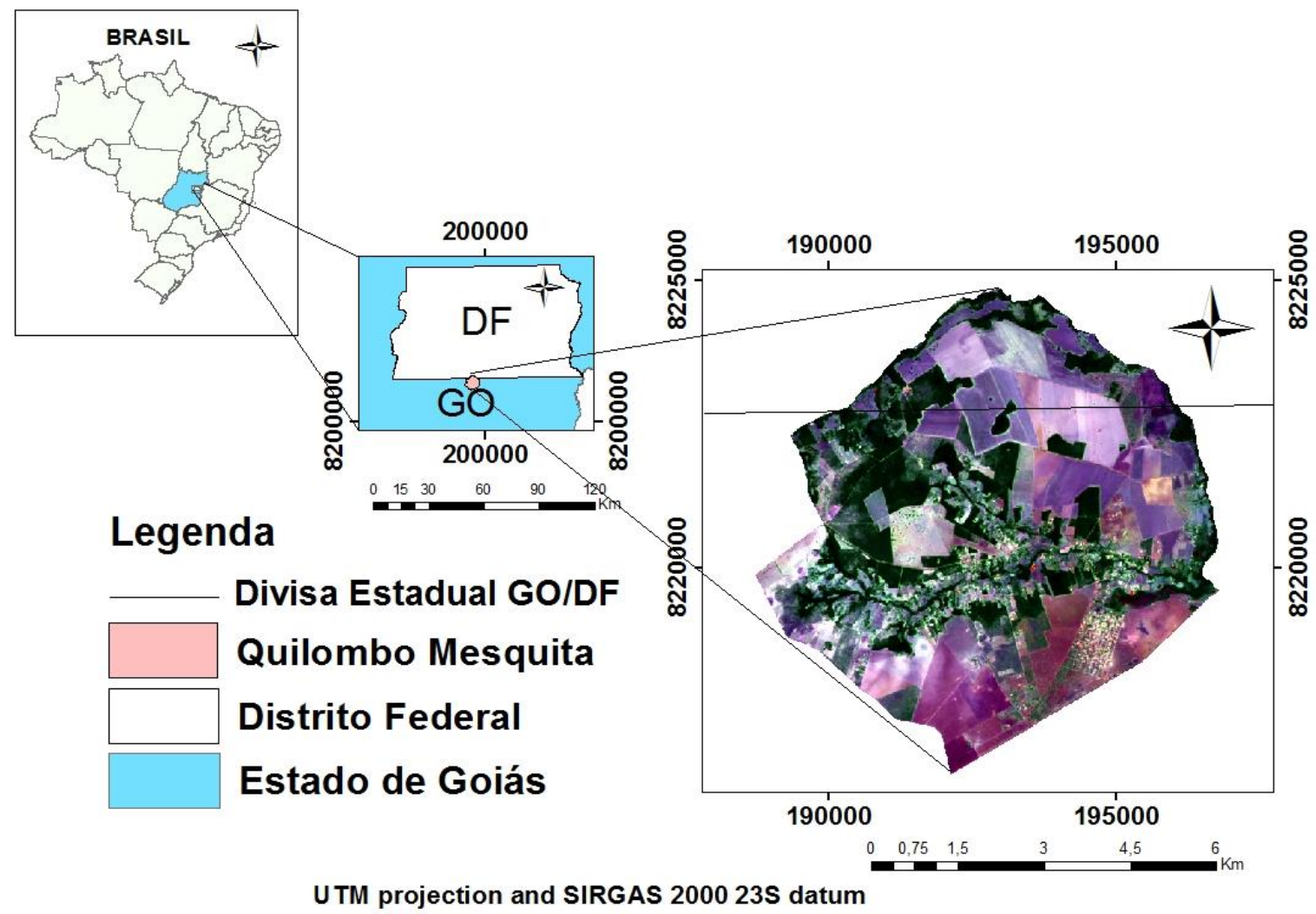

Figura 1. Localização do Quilombo Mesquita, GO, no centro-oeste do Brasil.

De acordo com a classificação de Köppen, o clima da área de estudo é do tipo Cwa, tropical de altitude, com temperatura e precipitação média anual de $20^{\circ} \mathrm{C}$ e $1.500 \mathrm{~mm}$ respectivamente. A figura 2 apresenta o diagrama de temperatura e da precipitação no período de janeiro a dezembro de 2014 do município da Cidade Ocidental, de acordo com EMBRAPA 
(2016). Verifica-se que a concentração de chuvas, com estação chuvosa iniciando em outubro e terminando em abril e estação seca, de maio a setembro.

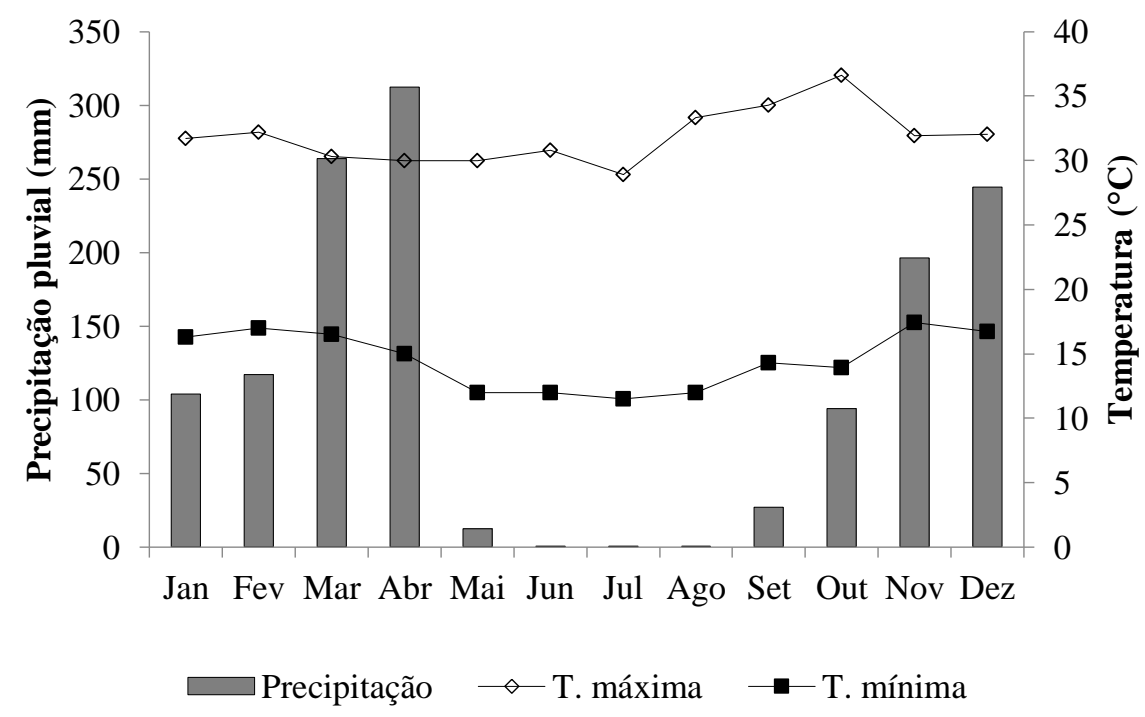

Figura 2. Temperatura e precipitação em 2014 no município de Cidade Ocidental - GO (EMBRAPA, 2016).

\subsubsection{Elaboração dos mapas de caracterização física, de aptidão agrícola e de uso e ocupação das terras do Quilombo Mesquita}

No estado de Goiás (GO), a principal fonte de informações pedológicas é o levantamento de reconhecimento de solos realizado pelo Projeto Radambrasil de 1978 (Brasil, 1981), com elaboração de mapa pedológico em escala 1:1.000.000. Os dados disponíveis gerados por essa escala não possibilitam uma caracterização detalhada dos solos e o entendimento preciso das relações entre os seus materiais de origem e superfícies geomorfológicas, responsáveis pela distribuição destes na paisagem do GO.

Todavia, com o intuito de caracterizar a área de estudo e subsidiar a elaboração dos mapas aptidão agrícola e de uso e ocupação foram levantadas informações sobre altimetria, declividade, geologia, geomorfologia, solos e vegetação do Quilombo Mesquita GO, sendo alguns mapas adquiridos e, outros elaborados, conforme detalhamento a seguir. 
Para a modelagem da altimetria e declividade foi realizado o modelo digital de terreno (MDT), contudo a carta altimétrica disponibilizada pelo Sistema Estadual de Geoinformação de Goiás (SIEG, 2016), com curvas de nível de 90 em 90 metros, não foram capazes de demonstrar a variação do terreno, que possibilitasse a geração de um mapa preditivo de classe de solo adequado à região de estudo. Portanto, foi adquirida uma cena Shuttle Radar Topography Mission (SRTM) de 30m, junto ao Science for a Changing World (USGS, 2016), na escala de 1:250.000. Dentro do Programa ArcGis 10.3, usando o Spatial Analyst Tools Straction; Extract by Mask, recortou-se uma porção da cena do SRTM 30, equivalente a área do Quilombo Mesquita. Com esse recorte foi possível criar uma carta altimétrica, com curvas de 10 em $10 \mathrm{~m}$, referente a escala de 1:25.000, com a ferramenta Arctoolbox Spatial Analyst Tools Surface Contour. Com a ferramenta Spatial Analyst Tools, Interpolation Topo to Raster gerou-se o mapa de altimetria. Com o mapa de altimetria, foi gerado o mapa de declividade, utilizando a ferramenta Spatial Analyst Tools Surface Slope, que foi reclassificada em quatro classes de declividade. E por fim, com o uso da ferramenta Spatial Analyst Tools Surface Curvature gerou-se o mapa de curvatura, sendo reclassificada em cinco classes.

Os mapas de geologia e geomorfologia foram adquiridos junto ao Sistema Estadual de Geoinformação de Goiás (SIEG, 2016), que foram recortados pela delimitação do Quilombo, GO, cujo mapeamento e delimitação da área de estudo, na escala 1:5.000, foi cedida pelo Instituto Nacional de Colonização e Reforma Agrária - INCRA (RTID/INCRA, 2011). Com o uso do Programa ArcGis 10.3, com as ferramentas Analysis Tools Extract Clip, recortou-se os mapas de geologia e geomorfologia.

O mapa de vegetação foi gerado por meio sensoriamento remoto em imagem de satélite Landsat 8-OLI, adquirido junto ao Science for a Changing World (USGS, 2016). A imagem foi processada no programa ENVI 5.2, sendo preliminarmente empilhada e corrigida 
radiometricamente, com o Radiometric Corretion Apply Gain and Offset, e, em seguida, corrigida atmosfericamente, usando o FLAASH Atmospheric Corretion. Após esse procedimento foi feito um recorte da imagem, utilizando um buffer da área de estudo. Com o intuito de gerar o mapa vegetação da área usou-se a ferramenta Classification Supervised Maximium Likelihood, por meio de coleta de amostras, representativas de fitofisionomias da vegetação nativa remanescente no recorte da imagem, utilizando a ferramenta Basic Tools Region of Interest ROI Tool. As amostras foram retiradas das fisionomias Cerradão, Cerrado, Mata de galeria, palhada e solo exposto. Como a fitofiosionomia Cerradão tem uma resposta espectral muito próxima à resposta espectral da Mata de galeria, foi feito um recorte da Mata, isso possibilitou uma classificação condizente com a realidade de campo.

Para a obtenção de uma legenda preliminar de mapeamento de solos mais próximo da realidade encontrado no campo, procedeu-se um levantamento de campo expedito, observando os cortes de estrada, e benfeitorias (buracos para retirada de terras, abertura de fossa séptica, barrancos provenientes de cortes de terreno para aplainamento, valas para dreno, etc.), bem como checagens no campo por meio de descrição morfológica completa de três perfis, com a finalidade de se caracterizar os tipos de solos, relacionando-os com o relevo, sua posição na paisagem e vegetação. Esse levantamento possibilitou a criação de banco de dados para se gerar uma legenda preliminar do mapeamento das classes de solos.

O banco de dados de solos foi associado aos mapas temáticos de geologia, declividade e curvatura. Usando a ferramenta Overlay, dentro do Spatial Analyst, com a função Fuzzy Overlay, foi gerado, a legenda preliminar de mapeamento dos solos, sendo usado os rasters de geologia, declividade e curvatura. Salienta-se que a ferramenta Fuzzy Overlay, só processa raster, tendo necessidade de transformar o mapa de geologia, que se encontrava no formato shapefile, em raster, usando o Conversion Tools To Raster Polygon to Raster. Para o processamento dentro da ferramenta Spatial Analyst Tools Overlay Fuzzy 
Overlay necessita-se reclassificar cada mapa envolvido no processo, pois o algoritmo trabalha com números inteiros. Assim, foram dados novos pesos a cada categoria constante nos mapas que foram gerados (Tabela 3). Com esses dados, foi gerado o mapeamento do solo, usando a ferramenta Overlay, dentro do Spatial Analyst, com a função Fuzzy Overlay, no algoritmo GAMMA, com Gamma optional 0,9.

Tabela 3. Pesos para cada classe a serem utilizadas na lógica Fuzzy para a elaboração da legenda preliminar de mapeamento de solos

\begin{tabular}{cc}
\hline Geologia (Classes) & Valor \\
\hline Q2a - Depósitos aluvionares & 2 \\
N1dl - Cobertura detrítico laterítica & 3 \\
MPpa3 - Grupo Paranoá, Unidade Rítmica Quartizítica & 4 \\
MPpa4 - Grupo Paranoá, Unidade Rítmica Pelito Carbonatada & 5 \\
\hline Declividade (Classes - \%) & Valor \\
\hline $0-3$ & 1 \\
$3-8$ & 2 \\
$8-20$ & 3 \\
$20-23,85$ & 4 \\
\hline Curvatura (Classes) & Valor \\
\hline$-0,27$ a $-0,11$ & 1 \\
$-0,11$ a $-0,04$ & 2 \\
$-0,04$ a $-0,01$ & 4 \\
$-0,01$ a 0,02 & 6 \\
0,02 a 0,06 & 8 \\
0,06 a 0,32 & 10 \\
\hline
\end{tabular}

Quanto ao mapa de aptidão agrícola, o mesmo foi gerado pela ferramenta Map Algebra Raster Calculator. Para tanto, utilizou-se a legenda preliminar do mapeamento de solos, que foi reclassificada, segundo a tabela 4. Primeiramente, somou-se a curvatura reclassificada com a declividade reclassificada. O resultado dessa operação foi somada a legenda preliminar de solos, resultando no mapa de aptidão agrícola das terras do Quilombo Mesquita - GO.

A avaliação da aptidão agrícola das terras da área de estudo foi efetuada com base no Sistema de Avaliação da Aptidão Agrícola das Terras (SAAT) proposto por Ramalho 
Filho \& Beek (1995), que consiste, de maneira geral, na interpretação das qualidades do ecossistema por meio da estimativa das limitações das terras para uso agrícola e das possibilidades de correção ou redução dessas limitações, de acordo com diferentes níveis de manejo.

Tabela 4. Pesos para cada classe a serem utilizadas no Raster Calculator para a elaboração do mapa de aptidão agrícola

\begin{tabular}{cc}
\hline Declividade (Classes - \%) & Valor \\
\hline $15-23$ & 3 \\
$8-15$ & 2 \\
$0-8$ & 1 \\
\hline Solos (Classes) & Valor \\
\hline $2-15$ & $2-15$ \\
$15-24$ & $15-24$ \\
$24-54$ & $24-54$ \\
$54-100$ & $54-100$ \\
$100-200$ & $100-200$ \\
\hline Curvatura (Classes) & Valor \\
\hline$-0,27$ a $-0,07$ & $-0,27$ a $-0,07$ \\
$-0,07$ a $-0,01$ & $-0,07$ a $-0,01$ \\
$-0,01$ a 0,03 & $-0,01$ a 0,03 \\
0,03 a 0,32 & 0,03 a 0,32 \\
\hline
\end{tabular}

O SAAT reconhece a importância dos problemas de solos de acordo com as condições socioeconômicas do agricultor e da região. Portanto, o SAAT considera três níveis de manejo, visando diagnosticar o comportamento das terras em diferentes níveis tecnológicos (Tabela 5). Assim, os níveis tecnológicos revelam o conjunto de tecnologias empregadas pelo agricultor e evoluem do nível A para o C (A-baixo, B-médio e C-alto). Quanto mais elevado o nível tecnológico (nível C), maior a inversão de capital e tecnologias, aumentando as possibilidades de superar as condições limitantes de uma determinada gleba de terra e viabilizar produções economicamente sustentadas.

No SAAT, para facilitar a montagem do mapa único de aptidão agrícola das terras foi organizada uma estrutura que reconhece grupos, subgrupos e classes de aptidão agrícola. 
O grupo de aptidão agrícola identifica o tipo de utilização mais intensivo das terras, ou seja, sua melhor aptidão. São reconhecidos seis grupos, representados pelos algarismos de 1 a 6 , em escala decrescente, segundo as possibilidades de utilização das terras. As limitações, que afetam os diversos tipos de utilização, aumentam do grupo 1 para o grupo 6, diminuindo, consequentemente, as alternativas de uso e a intensidade com que as terras podem ser utilizadas:

- Os grupos de aptidão 1, 2 e 3 identificam terras cujo uso mais intensivo é a lavoura;

- O grupo 4 representa terras cujo tipo de uso mais intensivo é a pastagem plantada;

- O grupo 5 compreende o uso mais intensivo das terras limita-se à silvicultura e pastagem natural.

O grupo 6 abrange áreas de terras consideradas inaptas para qualquer uma das atividades agrícolas citadas, estando sua ocupação condicionada à preservação da fauna e da flora.

Tabela 5. Níveis de manejo adotados no Sistema de Avaliação e Aptidão das Terras

\begin{tabular}{cl}
\hline Nível de Manejo & \multicolumn{1}{c}{ Características } \\
\hline & Baseado em práticas agrícolas que refletem um baixo nível tecnológico. \\
& Praticamente não há aplicação de capital para manejo, melhoramento e \\
A & $\begin{array}{l}\text { conservação das condições das terras e das lavouras; as práticas agrícolas } \\
\text { dependem do trabalho braçal, podendo ser utilizada alguma tração } \\
\text { animal com implementos agrícolas simples. }\end{array}$ \\
& Baseado em práticas agrícolas que refletem um nível tecnológico médio; \\
& caracteriza-se pela modesta aplicação de capital e de resultados de \\
& pesquisas para manejo, melhoramento e conservação das condições das \\
& terras e das lavouras; as práticas agrícolas estão condicionadas \\
& principalmente à tração animal. \\
\hline & Baseado em práticas agrícolas que refletem um alto nível tecnológico; \\
& caracteriza-se pela aplicação intensiva de capital e de resultados de \\
& pesquisas para manejo, melhoramento e conservação das condições das \\
& terras e das lavouras; a motomecanização está presente nas diversas fases \\
& da operação agrícola.
\end{tabular}


Para atender às variações que se verificam dentro do grupo, adotou-se a categoria subgrupo de aptidão agrícola. É o resultado conjunto da avaliação da classe de aptidão relacionada com o nível de manejo, indicando o tipo de utilização das terras. Por exemplo, na classificação da aptidão 1(a)bC, o algarismo 1, indicativo do grupo para lavouras, representa a melhor classe de aptidão dos componentes do grupo, uma vez que as terras pertencem à classe de aptidão boa, no nível de manejo C (grupo 1), classe de aptidão regular, no nível de manejo B (grupo 2) e classe de aptidão restrita, no nível de manejo A (grupo 3).

Para a avaliação das classes de aptidão agrícola das terras e, por conseguinte, dos grupos e subgrupos é feita através do estudo comparativo entre os graus de limitação atribuídos às terras, sendo consideradas as seguintes limitações:

- Deficiência de fertilidade: envolve a disponibilidade de nutrientes, toxicidade por alumínio, e fixação de fósforo;

- Deficiência de água;

- Excesso de água ou de deficiência de oxigênio: relacionado a partir das classes de drenagem;

- Suscetibilidade à erosão: relaciona-se à facilidade com que o solo é removido, por ação do vento e/ou da água; e

- Impedimentos à mecanização: considera a combinação “pedregosidade/rochosidade $\mathrm{x}$ declividade".

Assim, as classes de aptidão (boa, regular, restrita e inapta) são definidas para um determinado tipo de uso da terra em função dos graus de limitação (N: nulo, L: ligeiro, M: moderado, F: forte e MF: muito forte) das condições agrícolas das terras para os níveis de manejo A, B e C.

No estudo referente ao uso e à ocupação das terras do Quilombo Mesquita, foi utilizada uma imagem de satélite LANDSAT 8 (USGS, 2016), composição colorida em RGB 
das bandas 4, 5 e 7, do mês abril de 2016. Os programas usados para o tratamento da imagem e para geração dos mapas foram, respectivamente, o ENVI 5.2 e o ArcGis 10.3. Efetuou-se a correção geométrica da imagem LANDSAT, por meio do programa ENVI 5.2, na função registro, utilizando-se o modelo polinomial de primeiro grau e o método de reamostragem do vizinho mais próximo. A planta geral do Quilombo Mesquita foi delimitada, conforme descrito anteriormente. A partir da área do Quilombo delimitada, gerou-se um arquivo vetorial utilizado no recorte da imagem de satélite LANDSAT, no programa ENVI 5.2, por intermédio de geração e aplicação de máscara. A escala utilizada no mapeamento foi de 1:100.000 e a legenda preliminar do mapeamento revelou diferentes classes estabelecidas de uso e ocupação das terras, conforme critérios estabelecidos por Ribeiro \& Walter (1998).

\subsubsection{Caracterização e classificação dos Latossolos do Quilombo}

Considerando o levantamento de solos expedito no campo, verificou-se inicialmente uma maior proporção de Latossolos utilizados para a produção agrícola no Quilombo Mesquita, sendo os mesmos encontrados nas fitofisionomias Cerradão e Cerrado sensu stricto. Por isso, esses solos foram os escolhidos como base para desenvolver a pesquisa dessa tese. Assim, foram selecionadas três propriedades agrícolas, que continham os diferentes usos da terra a serem estudados, nas quais, em cada uma, foi aberto um perfil nas áreas nativas adjacentes aos usos da terra para confirmar se os mesmos possuíam a mesma classificação.

Portanto, foram realizadas checagens em campo por meio da descrição morfológica completa em três perfis de solos, os quais foram caracterizados e classificados devidamente. Assim, foram estudados três perfis ao longo de um transecto que cortou transversalmente os diversos aspectos da paisagem, com aberturas de trincheiras nas áreas de Cerradão e Cerrado sensu stricto, nas posições de topo (P1) e de terço médio das encostas (P2 e P3), com distâncias (em linha reta) aproximadas de $1.200 \mathrm{~m}$ e $2.200 \mathrm{~m}$, de P1 a P2 e de P2 a 
P3, respectivamente. Os perfis foram descritos segundo Santos et al. (2005), com coleta de amostras deformadas e indeformadas.

\subsubsection{Análises laboratoriais}

Além da morfologia, realizaram-se as análises físicas e químicas na terra fina seca ao ar (TFSA). Quanto às análises físicas, determinou-se a granulometria, a relação silte/argila e a densidade do solo, seguindo métodos da EMBRAPA (2011).

Quanto às analises químicas, foram realizadas: o $\mathrm{pH}$, utilizando-se relação 1: 2,5 de solo em água. Cálcio, magnésio e alumínio trocáveis foram extraídos por $\mathrm{KCl}$, o potássio e fósforo disponível, foram extraídos por Mehlich-1, a acidez potencial (H+Al) foi extraída com solução tamponada a pH 7,0 de acetato de cálcio. O carbono total foi determinado pelo método de Walkley-Black e a matéria orgânica, por sua vez, foi estimada com base no carbono orgânico. Todas as análises foram feitas utilizando-se metodologia proposta pela EMBRAPA (2011). Com base nos resultados das análises químicas, foram calculadas as somas de bases, a capacidade de troca catiônica (CTC), a saturação de bases (V\%) e de alumínio (m).

A partir dos atributos morfológicos, físicos, químicos e mineralógicos, os solos foram classificados de acordo com o Sistema Brasileiro de Classificação de Solos - SiBCS (EMBRAPA, 2013).

\subsection{RESULTADOS E DISCUSSÃO}

\subsubsection{Caracterização do meio físico do Quilombo}

$\mathrm{Na}$ área do Quilombo Mesquita, observa-se que o relevo apresenta áreas planas e residuais ao processo erosivo, com encostas suaves a declividades moderadas (Figura 3), e altitudes oscilando entre 885 e 1.066 m (Figura 4). 


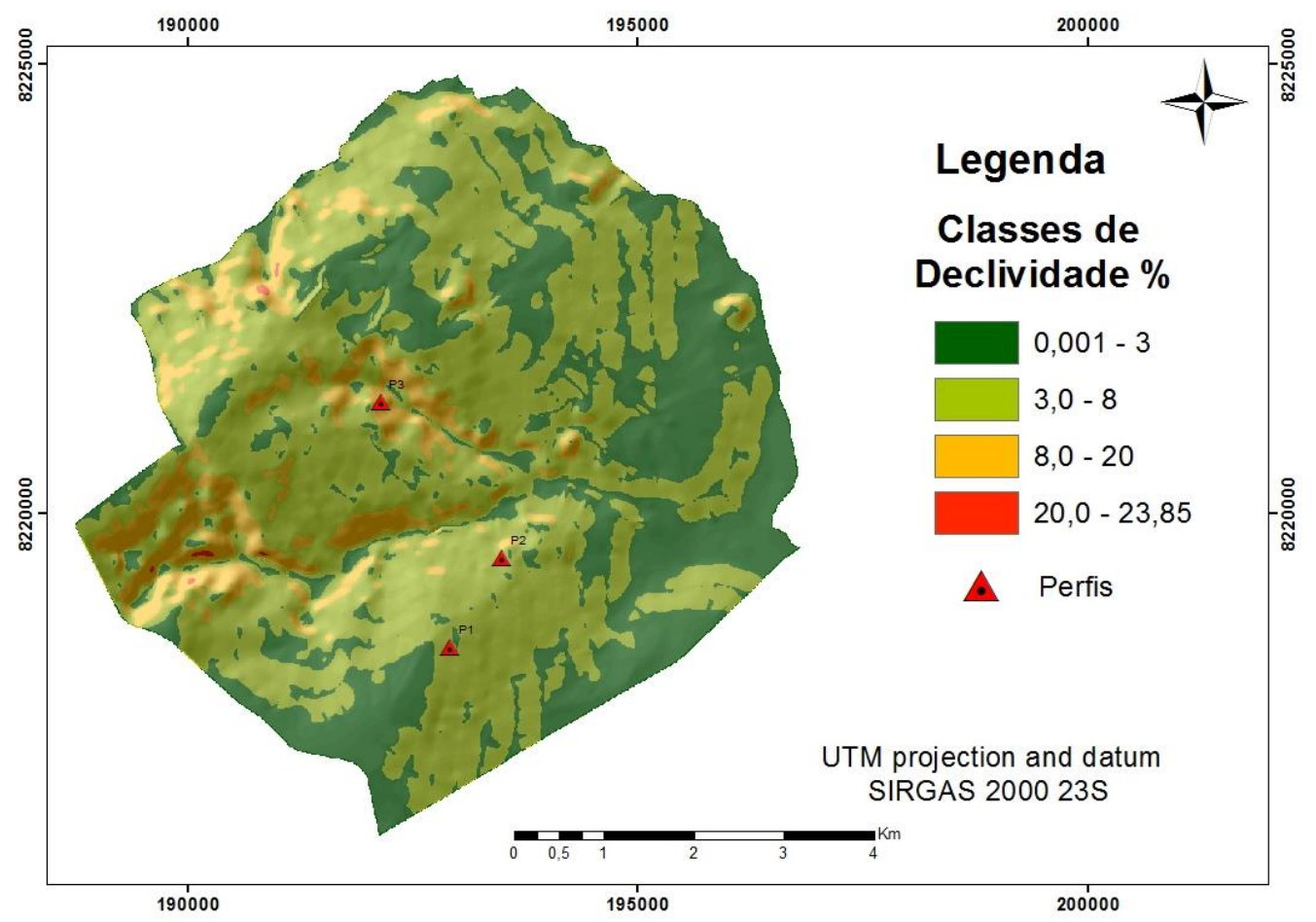

Figura 3. Mapa de classe de declividade do Quilombo Mesquita - GO, com localização dos pontos dos perfis de solos avaliados (Fonte: USGS, 2016).

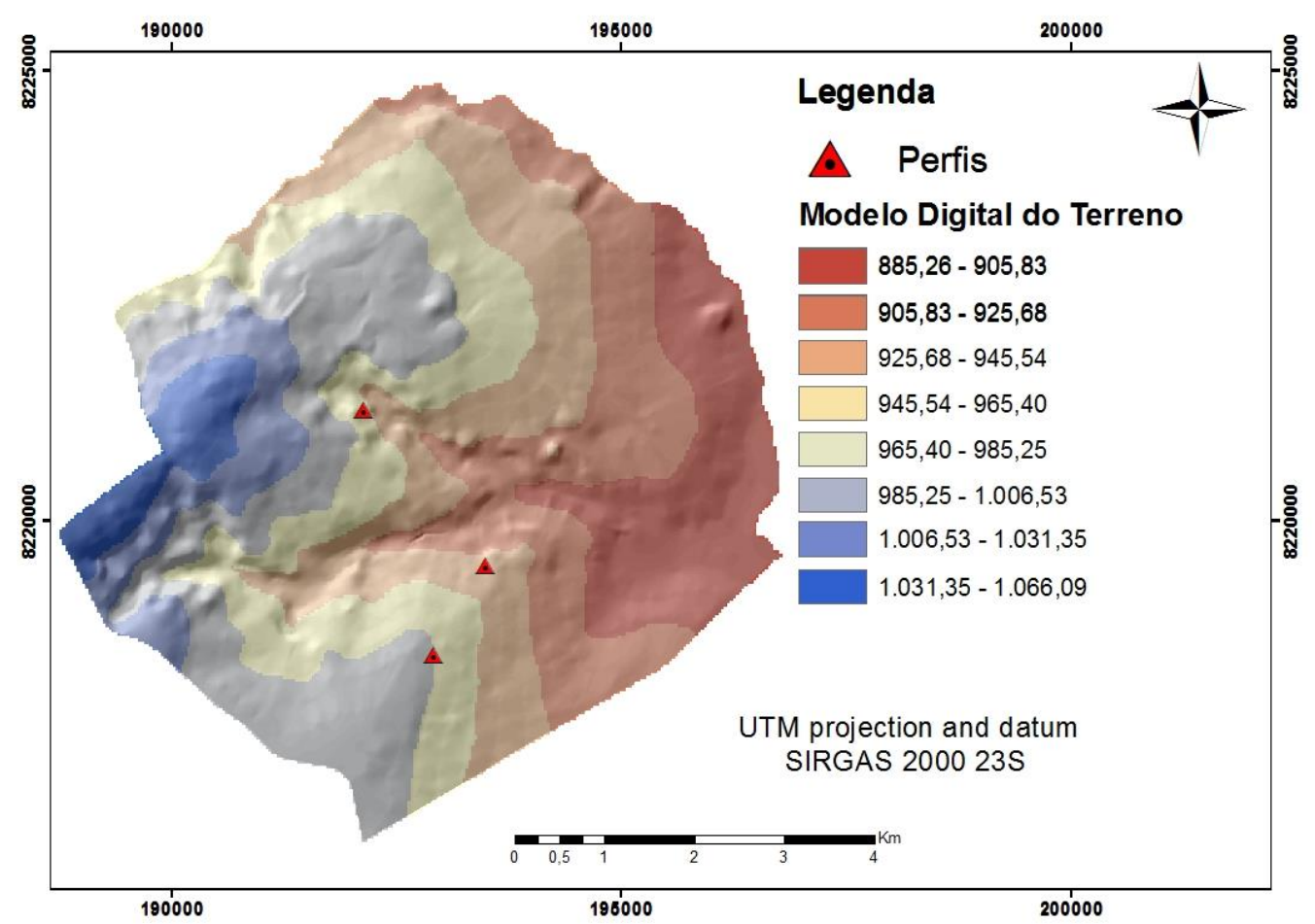

Figura 4. Mapa de hipsometria do Quilombo Mesquita - GO, com localização dos pontos dos perfis de solos avaliados (Fonte: USGS, 2016). 
Verifica-se que a maior parte da área possui relevo variando de plano para suave ondulado, conforme EMBRAPA (2011), atingindo cerca de $24 \%$ de declividade. Os perfis dos solos estudados estão inseridos na área de relevo suave ondulado (Figura 3) e, em altitudes que variam de 950 a 988 m (Figura 4).

Quanto à geologia (Figura 5), verificou-se que na área ocorrem litologias metasedimentares do Grupo Paranoá, de idade meso-proterozóica (Moreira, et al., 2008; Braun et al., 1993; Teixeira et al., 1993, Martins-Neto, 2009). Os dados sobre litoestratigrafia, sistemas deposicionais e geotectônica do Grupo Paranoá encontram-se descritos em Faria \& Dardenne (1995) que o caracterizam como uma sequência depositada originalmente em ambiente marinho, subdividida em doze litofácies e agrupadas em cinco megaciclos sedimentares.

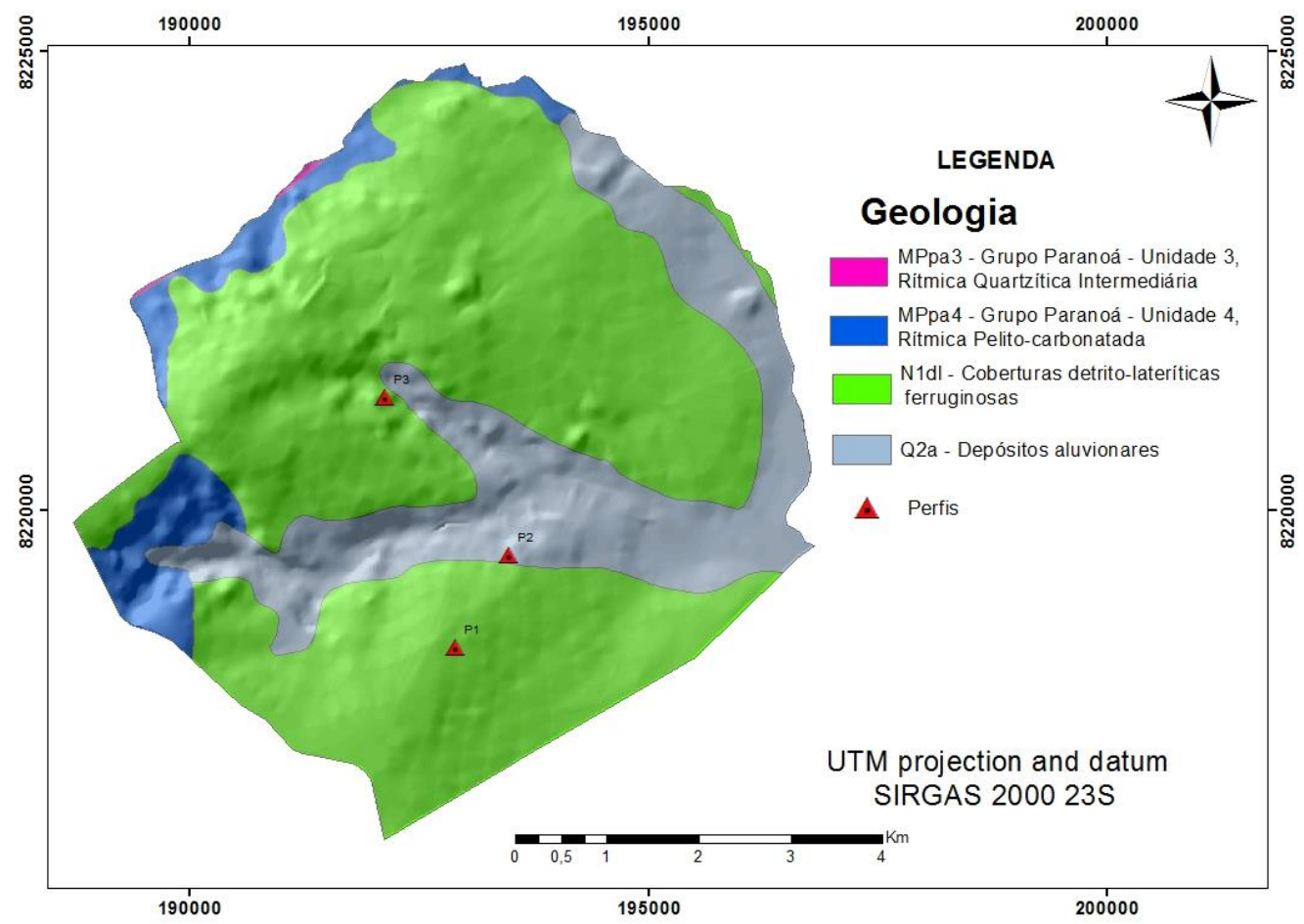

Figura 5. Mapa de geologia do Quilombo Mesquita - GO, com localização dos pontos dos perfis de solos avaliados (Fonte: SIEG, 2016).

Esses megaciclos foram denominados, da base para o topo: Unidade Conglomerática Quartzítica Rítmica Inferior; Unidade Siltito-Ardosiana; Unidade Rítmica Quartzítica Intermediária; e Unidade Rítmica Pelito-Carbonatada. No Quilombo Mesquita, 
foram encontradas as unidades: Rítmica Quartzítica Intermediária (MPpa3), Rítmica PelitoCarbonatada (MPpa4), Coberturas detrito-lateríticas ferruginosas (Ntdi) e Depósitos aluvionares (Q2a). O material de origem dos perfis estudados é constituído por rochas sedimentares de natureza psamo-pelítica, com granulação mais fina, constituindo o material de origem, de natureza sedimentar, já pré-intemperizado e de maneira geral bem drenado (Campos et al., 2013). De acordo com o mapa geológico (Figura 6) os perfis de solos avaliados 1 e 3 estão localizados na Unidade Ntdi e o perfil 2 na Q2a. Observa-se que as coberturas detrito-lateríticas ferruginosas se referem à Latossolos. Portanto, houve concordância já que se mapeia o material que aflora na superfície do solo. Quanto ao perfil 2, foi constatado em campo que a Unidade Depósito aluvionar não é tão extensa.

$\mathrm{Na}$ geomorfologia, a área estudada está inserida na superfície regional de aplainamento II - SRA II (Figura 6), segundo dados do SIEG (2016). Para Latrubesse \& Carvalho (2006), a unidade geomorfológica SRA-IIA é formada por amplas superfícies com cotas relativamente altas, padrões de relevo suavemente dissecado com baixa densidade de drenagem e presença de Latossolos, desenvolvida sobre rochas pré-cambrianas.

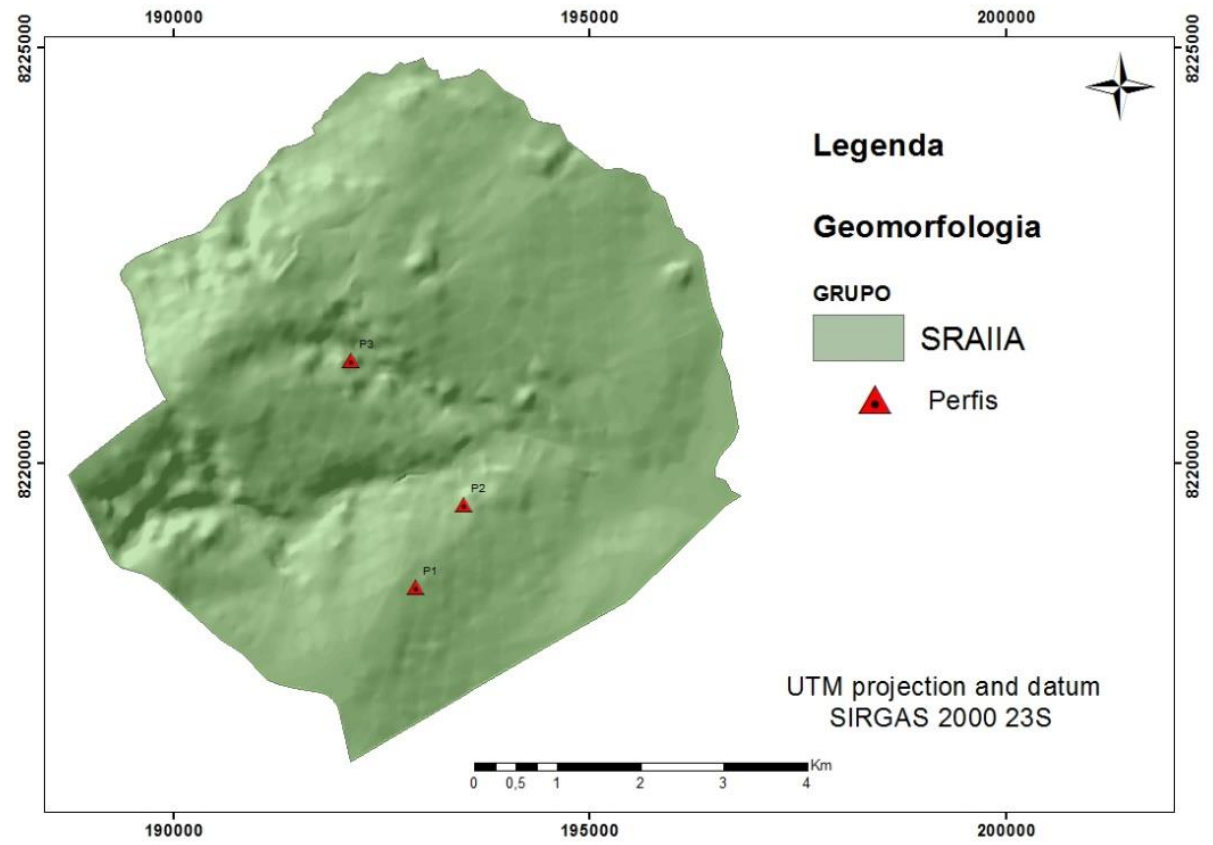

Figura 6. Mapa de geomorfologia do Quilombo Mesquita - GO, com localização dos pontos dos perfis de solos avaliados (Fonte: SIEG, 2016). 
A legenda preliminar do mapeamento das classes de solos de ocorrência dentro dos limites da área de estudo encontra-se na figura 7. Foram identificadas no Quilombo Mesquita, as seguintes classes de solos:

I. Latossolos;

II. Solos hidromórficos;

III. Neossolos;

IV. Plintossolos;

V. Solos com horizonte B textural; e

VI. Cambisssolos.

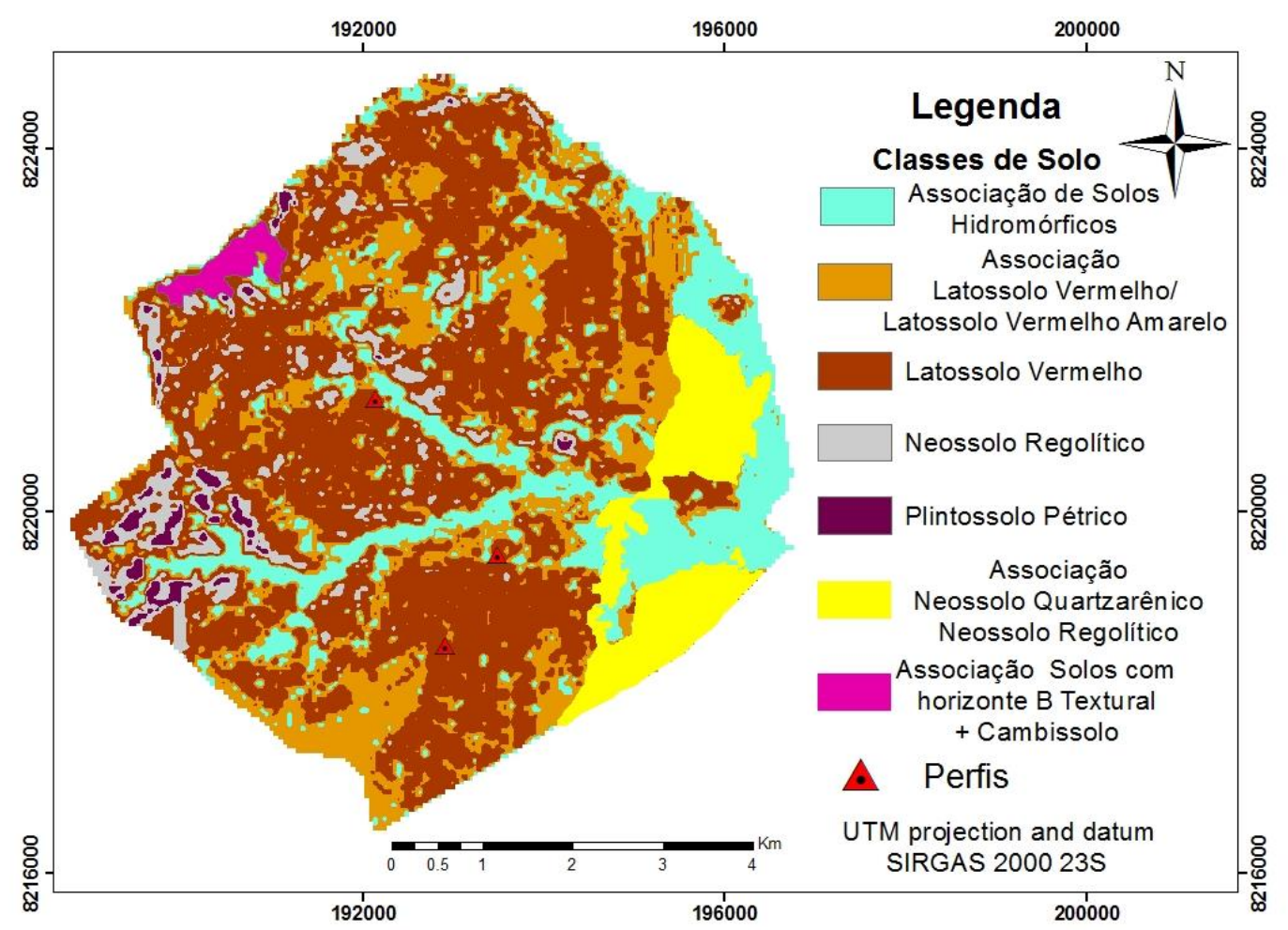

Figura 7. Legenda preliminar do mapeamento de solos do Quilombo Mesquita - GO, com localização dos pontos dos perfis de solos avaliados.

Os Latossolos representam os solos predominantes do Quilombo Mesquita, presentes nas áreas de relevo mais plano e com altitudes menores, representados por Latossolos Vermelhos distróficos típicos e Latossolos Vermelho-Amarelos distróficos 
petroplínticos, que compreendem as áreas majoritariamente agricultáveis por não quilombolas. Os Latossolos Vermelhos são solos muito intemperizados, com boas condições físicas, mas com pequena reserva de nutrientes para as plantas, representados normalmente por sua baixa a média capacidade de troca de cátions. Mais de 95\% dos Latossolos são distróficos e ácidos, com pH entre 4,0 e 5,5 e teores de fósforo disponível extremamente baixos, quase sempre inferiores a $1 \mathrm{~g} / \mathrm{cm}^{3}$ (EMBRAPA, 2013). A legenda preliminar revela que os três perfis selecionados, para serem caracterizados e classificados, estão incluídos nessa classe de solo.

Em relação à proporção de ocorrência, os Solos Hidromórficos representam a segunda colocação, desenvolvendo na planície de inundação dos cursos d'água do Quilombo, encontram-se permanente ou periodicamente saturados por água, salvo se artificialmente drenados. Caracterizam-se, assim, pela forte gleização, em decorrência da condição redutora, livre de oxigênio dissolvido, em razão da saturação por água durante todo o ano, ou pelo menos por um longo período, associado à demanda de oxigênio pela atividade biológica. $\mathrm{O}$ processo de gleização implica na manifestação de cores acinzentadas, azuladas ou esverdeadas, devido à redução e solubilização do ferro (EMBRAPA, 2013).

Foram também encontrados na área, Neossolos Regolíticos e Neossolos Quartzarênicos. Segundo EMBRAPA (2013), os Neossolos apresentam insuficiência de manifestação dos atributos diagnósticos, que caracterizam os diversos processos de formação dos solos, seja em razão de maior resistência do material de origem ou dos demais fatores de formação (clima, relevo ou tempo) que podem impedir ou limitar a evolução dos solos. Variam de solos rasos até profundos e de baixa a alta permeabilidade. Os Neossolos são solos de baixa fertilidade natural (distróficos), em geral, mais ácidos são mais e dependentes do uso de adubação e de calagem para correção da acidez. 
Os Plintossolos ocorrem em menor proporção no Quilombo Mesquita, constituídos por material mineral, apresentando horizonte plíntico, litoplíntico ou concrecionário (EMBRAPA, 2013), todos provenientes da segregação localizada de ferro, que atua como agente de cimentação. São fortemente ácidos, podem apresentar saturação de bases baixa (distróficos) ou alta (eutróficos), predominando os distróficos.

Solos com horizontes B textural (Nitossolos ou Argissolos) são solos com horizonte mineral com translocação de argila do horizonte A para o horizonte B. Ocorrem associados às áreas de relevo mais ondulado e de altitudes maiores. Podem apresentar alta (eutróficos) ou baixa (distróficos) fertilidade natural, acidez e teores de alumínio variáveis (EMBRAPA, 2013). Esses solos, principalmente os de maior fertilidade natural e de maior profundidade, apresentam potencial para o uso agrícola. Todavia necessitam de práticas conservacionistas, devido à maior suscetibilidade aos processos erosivos. Os Cambissolos são solos rasos, com elevado teor de minerais primários, presença significativa de fragmentos das rochas de origem, demonstrando processo pedogenético incipiente (EMBRAPA, 2013).

Quanto à vegetação, verifica-se que o mapa de vegetação gerado a partir da imagem Landsat 8 na área do Quilombo Mesquita constitui-se basicamente de Cerradão, Cerrado "sensu strictu" e Matas de galeria, ao longo das margens dos cursos de rios e córregos (Figura 8).

$\mathrm{Na}$ atualidade, restam poucos fragmentos desses conjuntos florísticos, devido à remoção das áreas nativas para a implantação de lavoura e constituição de pastos, dentre outros usos. Na área em que os quilombolas ocupam atualmente, há a maior preservação das áreas nativas, tendo sido conservada 47\% (RTID/INCRA, 2011). De acordo com a figura 8, verifica-se a ocupação dos quilombolas concentra-se ao redor das áreas de cerradão e de mata de galeria, terras consideradas de maior aptidão agrícola, conforme Goodland (1971) e Sano et al. (2010). 


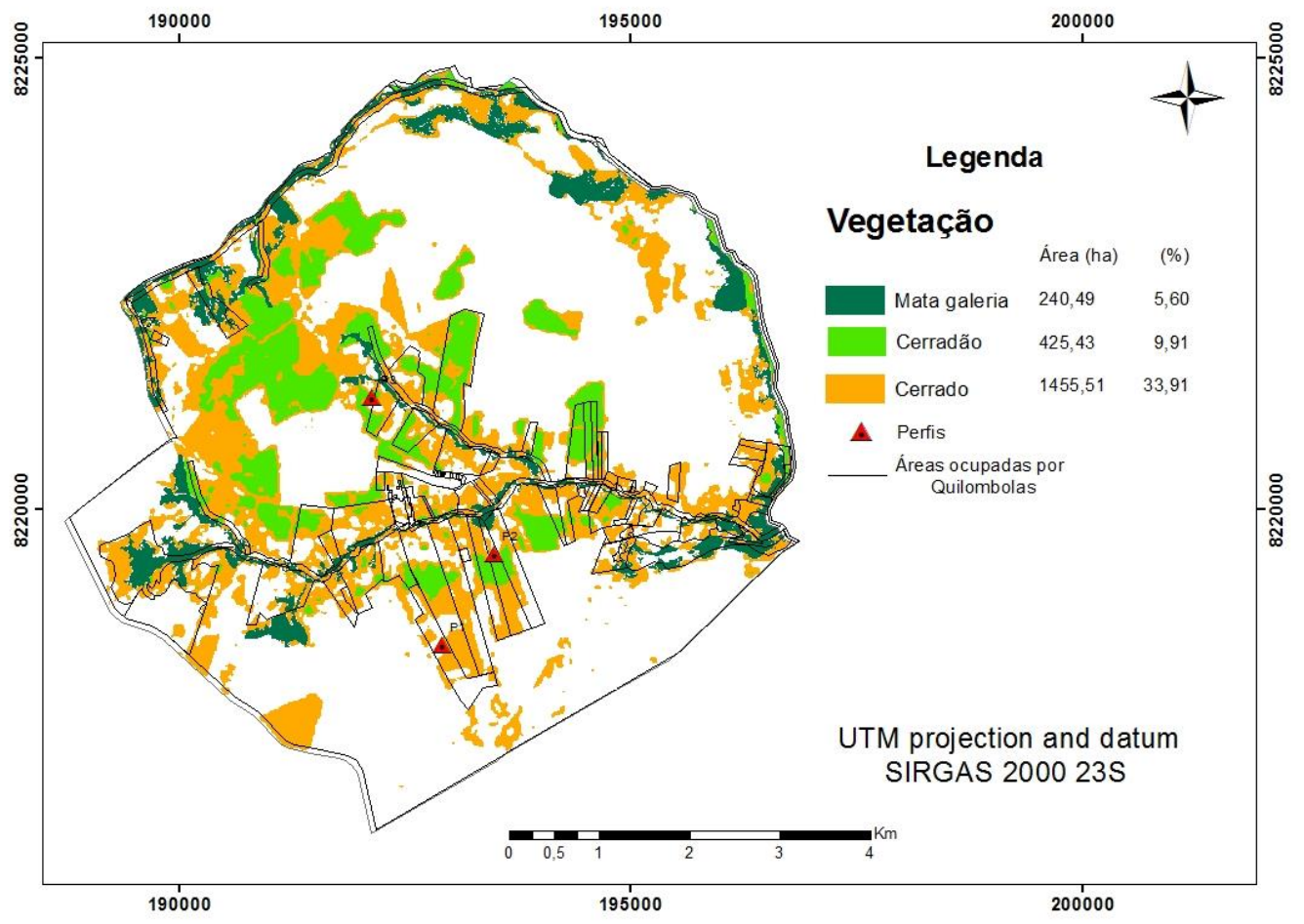

Figura 8. Mapa de vegetação do Quilombo Mesquita - GO, com localização dos pontos dos perfis de solos avaliados (Fonte: USGS, 2016).

\subsubsection{Uso e ocupação das terras em comparação à aptidão agrícola do Quilombo Mesquita}

As terras do Quilombo Mesquita em estudo são classificadas em seis classes de aptidão agrícola, de acordo com Ramalho Filho \& Beek (1995), tendo sido evidenciado as seguintes classes (Figura 9):

I. 2(b)c: terras pertencentes à classe de aptidão regular para lavouras nos níveis de manejo $\mathrm{C}$, restrita no $\mathrm{B}$ e inapta no nível A. Correspondem aos Latossolos Vermelhos.

II. 3(a)b: terras pertencentes à classe de aptidão regular para lavouras nos níveis de manejo B, restrita no A e inapta no nível C. Correspondem a Associação dos solos com B textural e Cambissolos. 
III. 3(b)c: terras pertencentes à classe de aptidão regular para lavouras nos níveis de manejo $\mathrm{C}$, restrita no $\mathrm{B}$ e inapta no nível A. Correspondem aos Latossolos Vermelhos-Amarelos.

IV. $4 \mathrm{p}$ : terras pertencentes à classe de aptidão regular para pastagens plantadas. Correspondem a Associação dos solos com B textural e Cambissolos e Latossolos Vermelhos-Amarelos.

V. $\quad 5(\mathrm{n})$ : terras pertencentes à classe de aptidão restrita para pastagem natural e inapta para silvicultura. Correspondem aos Neossolos Regolíticos e Plintossolos Pétricos.

VI. 6: terras sem aptidão para uso agrícola. Correspondem as Associações Solos Hidromórficos e Neossolos Regolíticos e Neossolos Quartzarênicos.

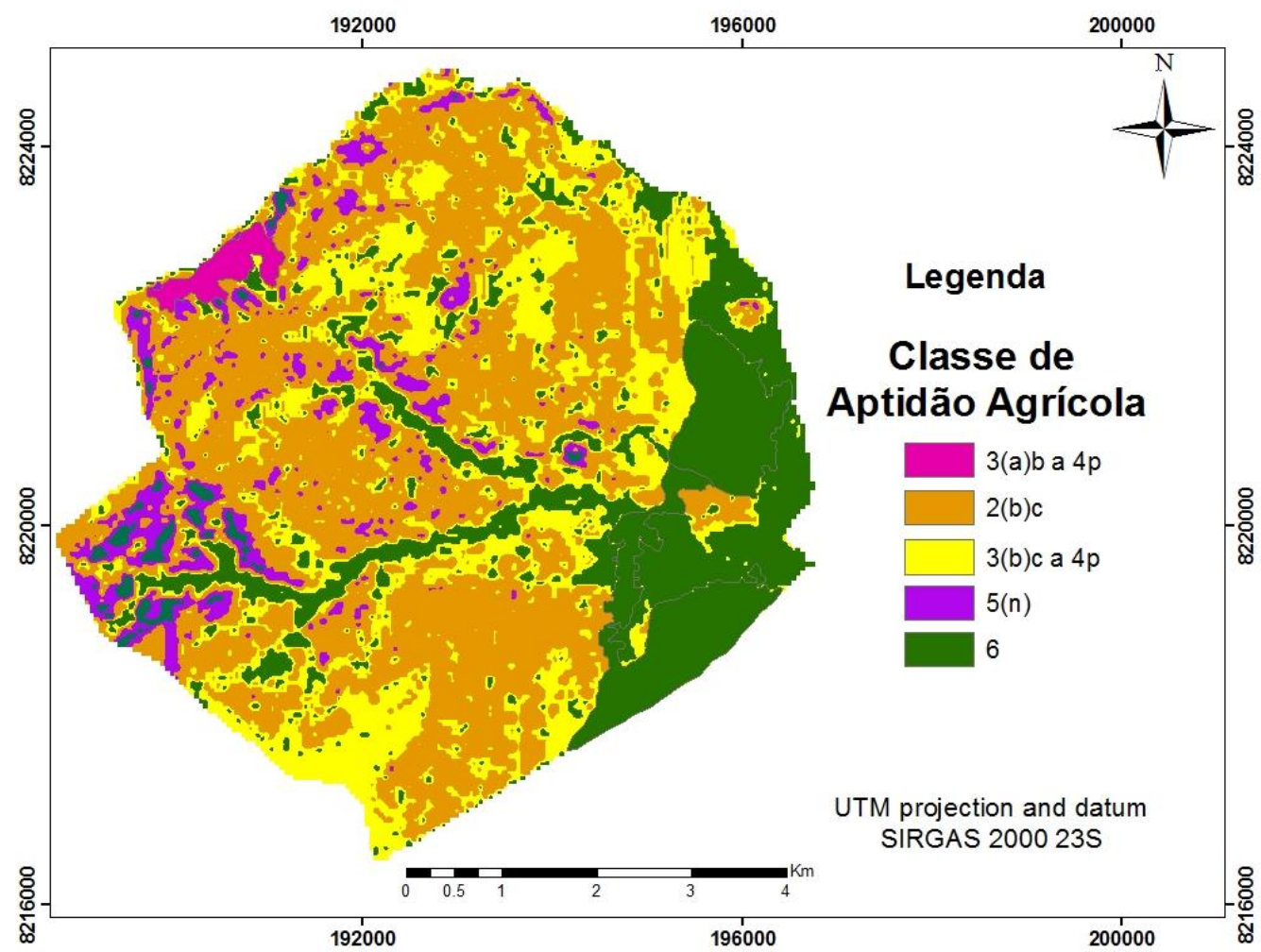

Figura 9. Mapa de aptidão agrícola das terras do Quilombo Mesquita - GO (conforme metodologia de Ramalho Filho \& Beek, 1995). 
Considerando a metodologia proposta por Ramalho Filho \& Beek (1995) e tendo em vista a tecnologia utilizada pelos quilombolas, pode-se enquadrá-los como nível de manejo A, modelo produtivo primitivo, baseado em práticas agrícolas que refletem um baixo nível tecnológico; praticamente sem aplicação de capital para o manejo, melhoramento e conservação das condições das terras e das lavouras, sendo as práticas agrícolas dependentes do trabalho braçal, podendo ser utilizada alguma tração animal com implementos agrícolas simples. Esse baixo nível tecnológico dos agricultores familiares quilombolas corrobora com o relatado por Mendes (2005), o qual afirma que no estado de Goiás, a agricultura familiar não tem o devido acesso às inovações tecnológicas, sistemas de crédito, e demais políticas agrícolas.

Assim, faz-se necessário a disponibilização de políticas públicas de inclusão produtiva que vise melhorar o nível tecnológico dos quilombolas para que os mesmos possam ser enquadrados no nível de manejo B (médio nível tecnológico), já que o Quilombo Mesquita possui grande proporção de terras com aptidão para lavouras, em classes pertencentes ao grupo 2 (2(b)c) e, ao grupo 3 (3(a)b e 3(b)c).

O mapa de uso e ocupação das terras do Quilombo Mesquita, gerado por meio da classificação supervisionada da imagem LANDSAT, ano 2016, encontra-se disposto na figura 10, verificando-se usos e ocupações diversificados. As classes estabelecidas de uso e ocupação das terras foram obtidas considerando que a vegetação foi subdivida de acordo com as características do estrato arbóreo da cobertura vegetal: formações florestais, formações savânicas e formações campestres, conforme a classificação de Ribeiro \& Walter (1998). No entanto, tal classificação para vegetação natural foi estendida às áreas com vegetação alterada, como vegetação agrícola e solo exposto. Assim, obtiveram-se as seguintes classes de uso e ocupação dos solos:

I. Jardim Edith: loteamento urbano; 
II. Mata de galeria: formação vegetal localizada nas margens dos corpos d'água, como córregos, lagos, represas e nascentes. Constituem florestas perenifólias, com formação arbórea alta e sempre verde; é considerada, pela Lei Federal nº.12.651/2012, área de preservação permanente - APP;

III. Cerradão: é uma vegetação florestal que ocorre tanto em solos distróficos quanto mesotróficos, sendo sua composição florística variável conforme a fertilidade do solo;

IV. Cerrado sensu stricto: é uma vegetação savânica composta por um estrato arbóreoarbustivo e outro herbáceo-graminoso;

V. Solo em pousio com palhada: áreas agricultáveis em período de pousio, recémsubmetidas a procedimentos de colheita ou com palhada para configurar assinatura espectral típica na imagem de satélite utilizada;

VI. Solo exposto: ausência de cobertura vegetal fotossinteticamente ativa.

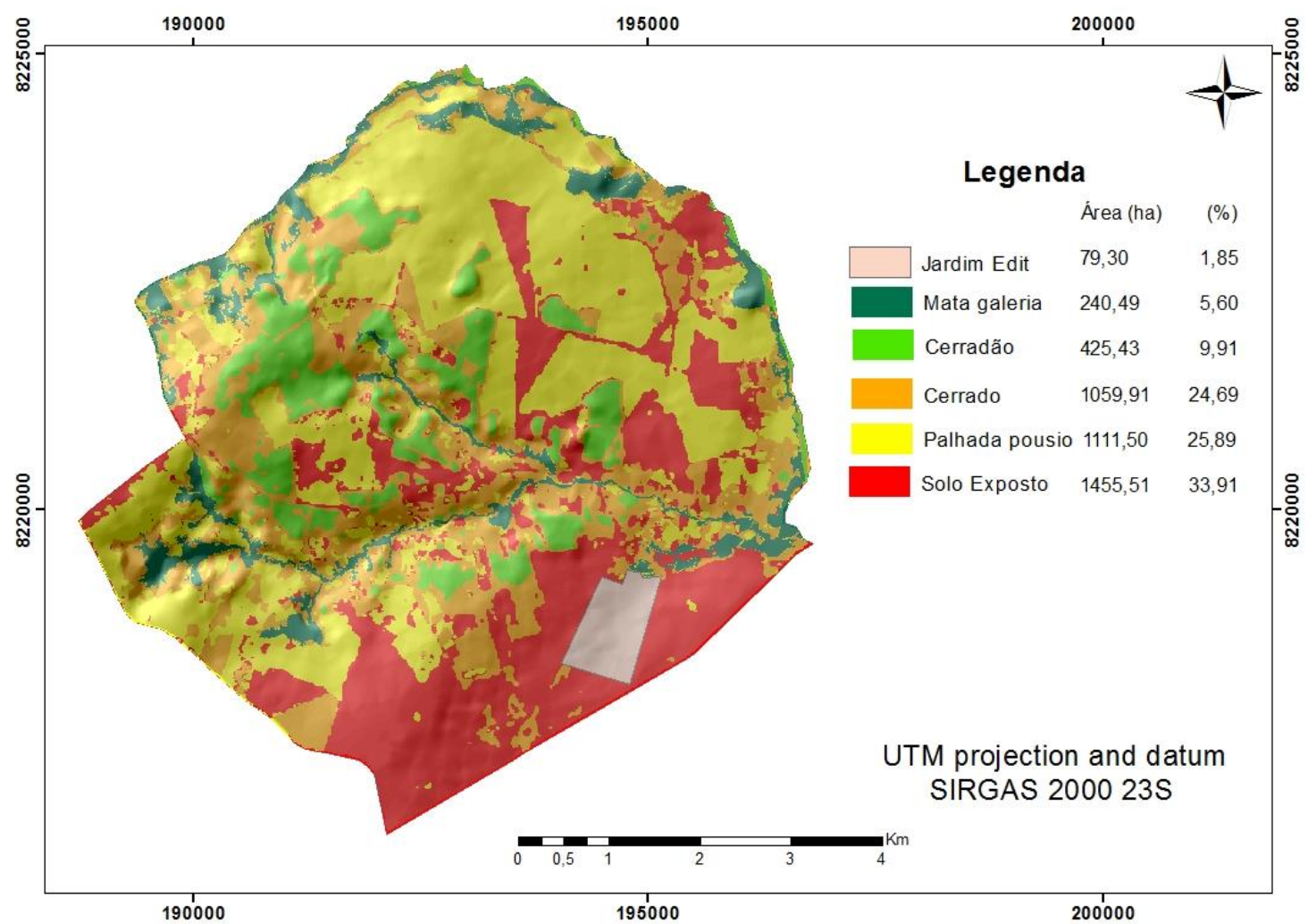

Figura 10. Mapa de uso e ocupação das terras do Quilombo Mesquita - GO (Abril/ 2016. Fonte: USGS, 2016). 
A área estudada possui 4.292,8259, com forte apelo na exploração agrícola sugerindo indícios de considerável perturbação antrópica nos recursos edáficos, o que pode comprometer a sustentabilidade do agroecossistema, particularmente ao se verificar uma maior proporção de solo em palhada pousio e exposto (Figura 10). Essas áreas compreendem, no geral, os Latossolos Vemelhos, que estão sendo utilizados de acordo com a aptidão agrícola das terras do Quilombo (Figura 9). Todavia o manejo que prevalece nessas áreas é o convencional, no qual o solo permanece sem cobertura e, na maioria das vezes, fica completamente exposto, sem vegetação, durante o período da entressafra, o que favorece a ocorrência da erosão e acelera o processo de degradação.

Assim, de acordo com a legenda da figura 10, observa-se o predomínio de áreas com solo exposto $(33,91 \%)$, incluindo-se nessa área o loteamento urbano Jardim Edit. Esse tipo de uso é bastante presente nas áreas ocupadas pelos não quilombolas (áreas a serem regularizadas pelo INCRA), resultante de agricultura extensiva e atividade pecuária, com exploração de pastagem, com nível de aplicação de tecnologia baixo, o que reflete na presença de pastagens degradadas, sendo visualizadas com ausência de cobertura vegetal, ficando o solo exposto aos agentes climáticos, demonstrando o predomínio do uso do preparo convencional do solo.

Observa-se ainda que o somatório das áreas destinadas à exploração agrícola solo exposto $(33,91 \%)$ e palhada pousio $(25,89 \%)$ representam $59,80 \%$ das áreas investigadas no Quilombo. Já em áreas sob pousio com palhada, provavelmente cultivadas com milho ou sistema de pousio com cobertura de milheto ou sorgo, como proteção do solo, tal como observado nas áreas estudadas.

Para Assis \& Lanças (2010) e Portugal et al. (2012), com a remoção da cobertura vegetal para a exploração agrícola, o solo é exposto à ação direta do clima, e, quando submetido à intensa atividade de cultivo, há o impacto negativo sobre os atributos físicos 
(rompe agregados, aumenta a densidade do solo, entre outros), químicos (diminui a MOS e, consequentemente, a CTC do solo) e biológicos (diminuição do carbono e nitrogênio microbiano), modificando sua qualidade, sendo evidenciado a vulnerabilidade dessas áreas à erosão hídrica e comprometimento da sustentabilidade ambiental.

Verifica-se ainda que nas áreas do Quilombo Mesquita de aptidão mais restrita (5(n) e 6), que compreendem os Solos Hidromórficos, Neossolos e Plintossolos, estão sendo erroneamente utilizadas, especialmente por não quilombolas, por palhada pousio e solo exposto, as quais precisarão ser recuperadas.

Para Netto et al. (2011), as atividades econômicas acabam por gerar a retirada da vegetação natural, expondo o solo a possíveis processos erosivos intensificados pela ação do escoamento superficial, carreando para os cursos de drenagem, sedimentos, detritos orgânicos e inorgânicos que interferem na qualidade da água e ainda podem assorear os cursos d'água. Desta forma, repassar o uso da terra no Quilombo Mesquita torna-se relevante e de grande importância para a preservação e manejo dos recursos naturais principalmente tratando-se das áreas de preservação permanente da vegetação no entorno dos cursos d'água.

Vale destacar que Rabelo et al. (2009), ao estudarem duas bacias hidrográficas de médio porte, representativas do estado de Goiás, verificaram que a bacia com um estágio avançado de conversão antrópica, apresentando cerca de $88 \%$ de sua área utilizada por agricultura e pastagem, apresentou qualidade de água inferior à da segunda bacia, numa condição inversa, ou seja, com $25 \%$ da área convertida em agricultura. Isso demonstra que o uso incorreto dos solos pode afetar a qualidade não somente desse recurso, como também da água.

Nas áreas de Latossolos, que revela forte potencial agrícola, é imprescindível a manutenção da matéria orgânica do solo (MOS), tendo em vista que em solos tropicais, particularmente os Latossolos, a MOS é a responsável pela capacidade de troca catiônica 
(CTC), melhorando também a estrutura física do solo. Essas áreas apresentam solos que exigem elevadas doses de fertilizantes e corretivos, em função da baixa disponibilidade de nutrientes e dos baixos teores de matéria orgânica e alumínio trocável.

Assim, essas áreas poderão ser utilizadas eficientemente pelos quilombolas, caso sejam disponibilizadas, para esse segmento da agricultura familiar, políticas públicas de inclusão produtiva, como infraestruturas (especialmente maquinários adaptados), bem como programas de especiais de crédito, e assistência técnica, que busquem uma agricultura agroecológica, pautada no manejo sustentável do solo e das culturas, visando o equilíbrio do uso do solo e a manutenção dos seus atributos que propiciem produtividades adequadas com baixo custo. Ademais, tanto os agricultores, como a assistência técnica, devem estar predispostos a mudanças, conscientes de que o sistema produtivo deve manter a cobertura do solo, sendo isso relevante para alcançar êxito e rentabilidade na atividade agrícola.

A assistência técnica capacitada é fundamental, pois, as tecnologias, principalmente na fase inicial de adoção, requerem acompanhamento permanente e contínuo, bem como de programas de pesquisas (visando à implantação de tecnologias sociais adaptadas), por meio de alternativas econômicas de uso que associem técnicas de produção menos intensivas com práticas simples de conservação dos recursos naturais, como: plantio direto, adubações minerais ou orgânicas equilibradas e adoção de adubação verde, formação de cobertura morta, rotação e sucessão de culturas, cultivo em nível, renques de vegetação e terraços, entre outras.

As áreas ocupadas por Cerrado sensu stricto (24,69\%), Cerradão (9,91\%), e Mata de Galeria (5,60\%) totalizam 39,60\% das áreas do Quilombo em questão. Segundo o novo Código Florestal (Lei 12.651/2012), a Mata de Galeria é área de preservação permanente, não podendo ser alterada. Enquanto que as áreas remanescentes de vegetação do Cerrado somariam $34,6 \%$, a qual pode ser computada como reserva legal, já que segunda a Lei acima 
“todo imóvel rural deve manter área com cobertura de vegetação nativa, a título de Reserva Legal, em 20\% nas demais regiões do País, que não estejam localizadas na Amazônia Legal”.

Embora essa área proposta como reserva legal seja superior ao previsto em Lei, poder-se-ia questionar a possibilidade de abertura de novas áreas, contudo deve-se levar em conta que cerca de $60 \%$ do Quilombo possui áreas abertas para fins de atividades agropecuárias, e das vantagens da manutenção da diversidade de fauna e flora e da preservação dessas áreas. De acordo com o novo Código Florestal no "Art $15, \S 2^{\circ}-\mathrm{O}$ proprietário ou possuidor de imóvel com Reserva Legal conservada e inscrita no Cadastro Ambiental Rural - CAR de que trata o art. 29, cuja área ultrapasse o mínimo exigido por esta Lei, poderá utilizar a área excedente para fins de constituição de servidão ambiental, Cota de Reserva Ambiental e outros instrumentos congêneres previstos nesta Lei” (Lei 12.651/2012). Assim, a Lei possibilita a exploração econômica da Reserva Legal mediante manejo sustentável, ou seja, essas áreas tem o potencial de serem usadas como reserva de carbono, ou, manejadas agroecologicamente.

O seqüestro de carbono refere-se a processos de absorção e armazenamento de $\mathrm{CO}_{2}$ atmosférico, com intenção de minimizar seus impactos no ambiente, já que se trata de um gás de efeito estufa (GEE) (Renner, 2004). De acordo com Bustamante et al. (2006), os estoques de carbono em Latossolos da região do Cerrado sob diferentes coberturas vegetais variaram de 99 até $209 \mathrm{Mg} \mathrm{ha}^{-1}$, para $100 \mathrm{~cm}$ de profundidade do solo, sendo esse valor maior em áreas nativas.

Assim, para Fernandes et al. (2008), por meio da manutenção e regeneração da vegetação do Cerrado, aumenta-se consideravelmente a biomassa e consequentemente o estoque de carbono fixado, possibilitando o desenvolvimento de projetos de conservação, preservação ou mesmo com a recuperação de áreas degradadas, servindo como alternativa para o mecanismo de desenvolvimento limpo (MDL) e consequente Certificado de Emissão 
Reduzida. Segundo Ribeiro (2006), o MDL foi instituído com o objetivo principal de auxiliar os países em desenvolvimento na implantação de tecnologias de recuperação e preservação ambiental e de ajudar os países desenvolvidos a cumprir suas metas de redução de emissões.

O valor pago pela tonelada de carbono em projetos florestais de MDL varia entre US\$ 3,00 a US\$ 5,00 por tonelada fixada, segundo parâmetros do Programa das Nações Unidas para o Desenvolvimento Sustentável (Renner, 2004), podendo esse valor variar de acordo com a região e país. Dessa forma, a manutenção das áreas nativas é uma enorme possibilidade de renda para os quilombolas de Mesquita.

\subsubsection{Os Latossolos do Quilombo Mesquita}

Nos perfis de solos estudados ao longo do transecto selecionado do Quilombo Mesquita foi enfatizado o horizonte diagnóstico $\mathrm{Bw}$. Na área estudada, foi confirmada a ocorrência de Latossolos Vermelhos nas posições de topo e de terço médio das encostas (Figura 11), em relevo plano e suave ondulado, com altitudes variando de 950 a $988 \mathrm{~m}$, constituindo solos altamente intemperizados, evidenciando processo acentuado de latolização, com mesmo material de origem, mas em áreas de vegetação diferentes (Tabela 6).

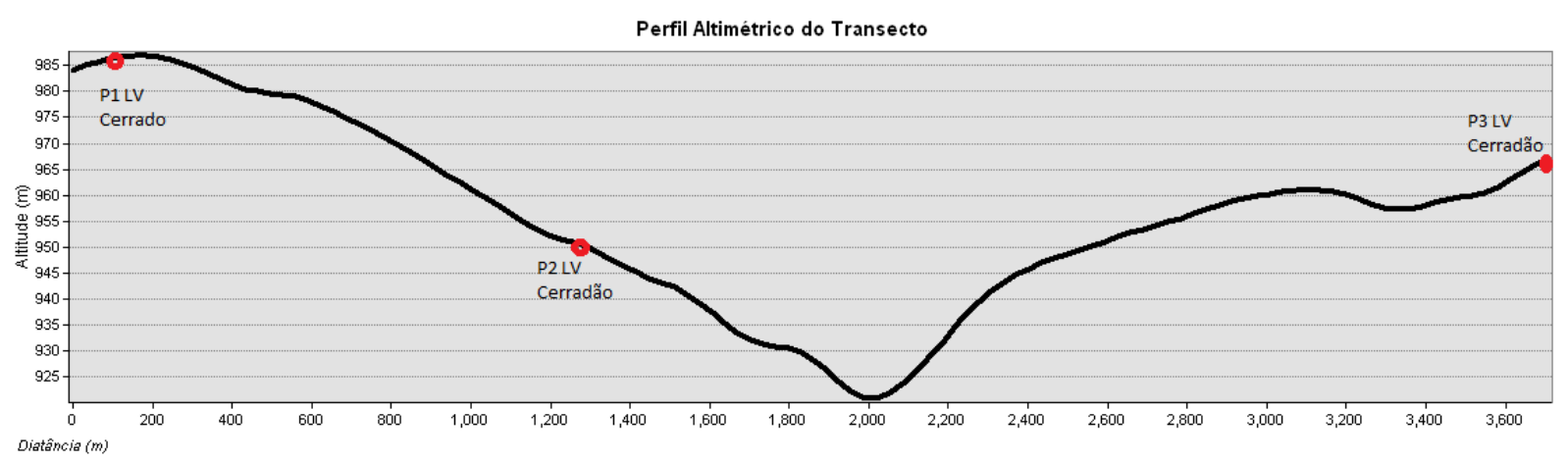

Figura 11. Perfil altimétrico do transecto estudado. 
Tabela 6. Informações gerais dos solos do transecto estudado

\begin{tabular}{|c|c|c|c|c|c|c|c|c|}
\hline Perfil & $\begin{array}{l}\text { Coord. } \\
\text { (UTM)* }\end{array}$ & $\begin{array}{r}\text { Situação } \\
\text { paisagem }\end{array}$ & $\begin{array}{c}\text { Relevo } \\
\text { local }\end{array}$ & $\begin{array}{c}\text { Material de } \\
\text { origem }\end{array}$ & $\begin{array}{l}\text { Vegetação } \\
\text { atual }\end{array}$ & $\begin{array}{l}\text { Alt. } \\
\text { (m)* }\end{array}$ & Drenagem & $\begin{array}{c}\text { Pedre. e } \\
\text { roch.* }\end{array}$ \\
\hline $\mathrm{P} 1$ & $\begin{array}{l}0192953 / \\
8218484\end{array}$ & $\begin{array}{l}\text { Topo de } \\
\text { elevação }\end{array}$ & Plano & $\begin{array}{c}\text { Grupo } \\
\text { Paranoá, } \\
\text { composto }\end{array}$ & $\begin{array}{c}\text { Cerrado } \\
\text { sensu } \\
\text { stricto }\end{array}$ & 988 & $\begin{array}{c}\text { Bem } \\
\text { drenado }\end{array}$ & Ausente \\
\hline $\mathrm{P} 2$ & $\begin{array}{l}0193355 / \\
8219548\end{array}$ & $\begin{array}{l}\text { Terço } \\
\text { médio }\end{array}$ & $\begin{array}{c}\text { Suave } \\
\text { ondulado }\end{array}$ & $\begin{array}{c}\text { por uma } \\
\text { sucessão } \\
\text { psamo- }\end{array}$ & Cerradão & 950 & $\begin{array}{c}\text { Bem } \\
\text { drenado }\end{array}$ & Ausente \\
\hline P3 & $\begin{array}{l}0192187 / \\
8221258\end{array}$ & $\begin{array}{l}\text { Terço } \\
\text { médio }\end{array}$ & $\begin{array}{c}\text { Suave } \\
\text { ondulado }\end{array}$ & $\begin{array}{c}\text { pelito- } \\
\text { carbonatada } \\
\text { depositada } \\
\text { em } \\
\text { condições } \\
\text { plataformais }\end{array}$ & Cerradão & 970 & $\begin{array}{c}\text { Bem } \\
\text { drenado }\end{array}$ & Ausente \\
\hline
\end{tabular}

Ao longo do transecto selecionado verifica-se ainda a presença de fitofisionomias florestais (Cerradão) e savânicas (Cerrado sensu stricto). Para Medeiros (2004); Marimon Junior \& Haridisan (2005); Spera et al., (2005), Barros (2012), Rodrigues \& Araújo (2013);a diferença pode ser devida a variações locais da hidrografia, profundidade do lençol freático e profundidade dos solos, fenologia e forma de dispersão das espécies, herbivoria, além de ações antrópicas, incluindo as frequentes queimadas.

Silva et al. (2015) estudando a relação entre solo e vegetação em uma área do Bioma Cerrado sobre influência do Grupo Urucuia verificaram que o teor de matéria orgânica, que está relacionada com o nível de drenagem do solo, é um dos principais fatores de diferenciação entre os ambientes estudados, que, juntamente com a textura, influenciaram diretamente nas características dos solos e determinaram a distribuição das diferentes fitofisionomias na área de estudo.

\subsubsection{Atributos morfológicos}

Quanto à classificação dos solos segundo o SiBCS, os três solos apresentaram a seguinte sequência: P1 e P3 (A, AB, BA e Bw) e P2 (A, AB, Bw) (Figura 12). 

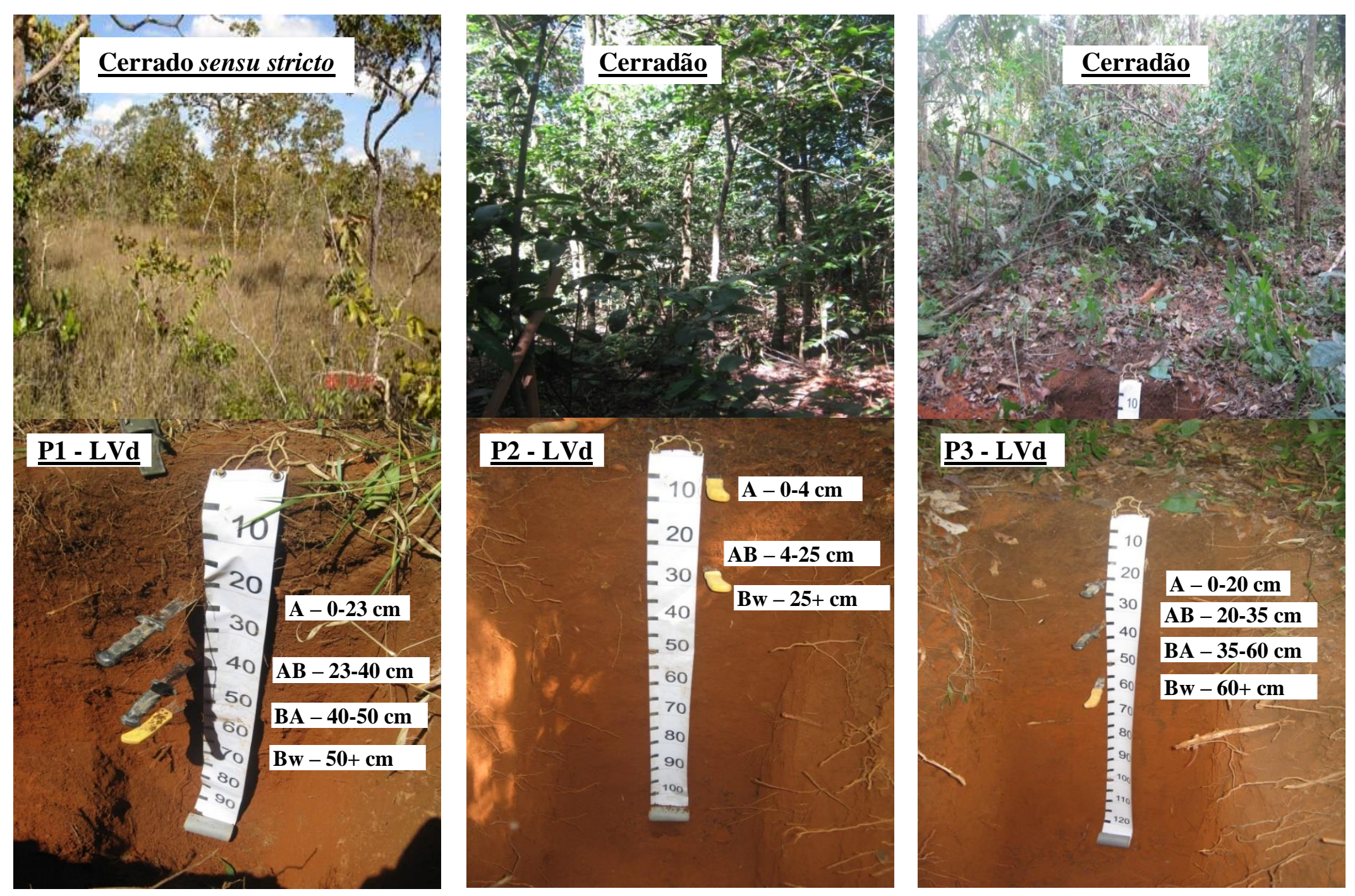

Figura 12. Fotos dos perfis de solos estudados e da vegetação ao longo do transecto selecionado, sendo P1: LVd Cerrado sensu stricto e P2 e P3: LVd Cerradão. 
Diante disso, todos os perfis foram enquadrados na ordem, subordem, grande grupo e subgrupo como Latossolo Vermelho distrófico típico. Ademais, a descrição do solo no campo compreende o registro das suas características, através do estudo e do exame do seu perfil em seu meio natural, permitindo, por exemplo, observar a estrutura do solo, a transição entre horizontes e a profundidade explorada pelo sistema radicular. Nesse contexto, a distribuição dos solos no transecto é bastante homogênea, com solos profundos, apresentando horizonte Bw com mais de $120 \mathrm{~cm}$, e bem drenados (Tabela 7 e Figura 12).

Em todos os perfis, os horizontes superficiais e subsuperficiais apresentaram cores vermelhas escuras (10 R e 2,5 YR) (Tabela 7), sendo esse padrão decorrente da presença de óxidos de Fe, podendo essa cor ser mascarada pelo efeito da matéria orgânica (Cornell \& Schwertmann, 1996) no horizonte superficial. Verificou-se que, em P2 e P3 a cor vermelha do horizonte A tem enorme influência da matéria orgânica do solo, enquanto que em P1 a cor deve estar relacionada à presença de óxidos de $\mathrm{Fe}$, que é condicionada pela predominância de hematita nos perfis em questão (Gomes et al., 2004).

Quanto à estrutura, o formato granular evidenciou-se nos horizontes superficiais e subsuperficiais, com tamanho variável de muito pequena a grande e grau de desenvolvimento forte. Os solos formados a partir de material de natureza pelítica, segundo Resende et al. (2005) e Schaefer et al. (2008), apresentam além da caulinita, apontada por vários autores como o mineral mais expressivo na fração argila da maioria dos Latossolos brasileiros, goethita, hematita e gibbsita, em proporções no solo que dependem de variações do material de origem, da intensidade de intemperismo e das condições de drenagem. Ademais, os sesquióxidos de Fe e Al são responsáveis pelo alto grau de grau dos solos, desenvolvendo estrutura mais próxima do tipo granular (Silva et al., 1995, 1997, 1998; Chagas et al., 1999). 
Tabela 7. Caracterização morfológica dos perfis de Latossolos Vermelhos do Quilombo Mesquita - GO

\begin{tabular}{|c|c|c|c|c|}
\hline \multirow{2}{*}{ Horizonte } & \multirow{2}{*}{$\begin{array}{l}\text { Profundidade } \\
(\mathbf{c m})\end{array}$} & Cor Úmida & \multirow{2}{*}{ Estrutura } & \multirow{2}{*}{ Consistência } \\
\hline & & Matriz Munsell & & \\
\hline \multicolumn{5}{|c|}{ Perfil 1 - Latossolo Vermelho distrófico típico } \\
\hline A & $0-23$ & 10R 4/3 & $\begin{array}{l}\text { Granular grumosa, estrutura forte, pequena } \\
\text { a muito pequena }\end{array}$ & $\begin{array}{l}\text { Friável (úmida); lig. plástico e lig. } \\
\text { pegajoso (molhada) }\end{array}$ \\
\hline $\mathrm{AB}$ & $23-40$ & 10R 3/6 & $\begin{array}{c}\text { Granular grumosa, estrutura forte, pequena } \\
\text { a muito pequena }\end{array}$ & $\begin{array}{c}\text { Friável (úmida), lig. plástico e lig. } \\
\text { pegajoso (molhada) }\end{array}$ \\
\hline BA & $40-50$ & 10R 4/6 & $\begin{array}{c}\text { Granular grumosa, estrutura forte, pequena } \\
\text { a muito pequena }\end{array}$ & $\begin{array}{c}\text { Friável (úmida), lig. plástico e lig. } \\
\text { pegajoso (molhada) }\end{array}$ \\
\hline & $40-50$ & $10 \pi / 0$ & Granular grumosa, estrutura forte, pequena & Friável (úmida), lig. plástico e lig. \\
\hline $\mathrm{Bw}$ & $50+$ & 10R 6/8 & a muito pequena & pegajoso (molhada) \\
\hline \multicolumn{5}{|c|}{ Perfil 2 - Latossolo Vermelho distrófico típico } \\
\hline A & $0-4$ & 10R $2,5 / 2$ & a muito pequena & pegajoso (molhada) \\
\hline $\mathrm{AB}$ & $4-25$ & 10R 4/6 & $\begin{array}{c}\text { Granular grumosa, estrutura forte, pequena } \\
\text { a muito pequena }\end{array}$ & $\begin{array}{c}\text { Friável (úmida), lig. plástico e lig. } \\
\text { pegajoso (molhada) }\end{array}$ \\
\hline $\mathrm{Bw}$ & $25+$ & 10R 4/8 & $\begin{array}{c}\text { Granular grumosa, estrutura forte, pequena } \\
\text { a muito pequena }\end{array}$ & $\begin{array}{c}\text { Friável (úmida), lig. plástico e lig. } \\
\text { pegajoso (molhada) }\end{array}$ \\
\hline \multicolumn{5}{|c|}{ Perfil 3 - Latossolo Vermelho distrófico típico } \\
\hline A & $0-20$ & $2,5 \mathrm{YR} 3 / 4$ & $\begin{array}{c}\text { Granular grumosa, estrutura forte, pequena } \\
\text { a muito pequena }\end{array}$ & $\begin{array}{l}\text { Moderada (úmida), lig. plástico e } \\
\text { pegajoso (molhada) }\end{array}$ \\
\hline $\mathrm{AB}$ & $20-35$ & 2,5YR 3/6 & $\begin{array}{c}\text { Granular grumosa, estrutura forte, pequena } \\
\text { a muito pequena }\end{array}$ & $\begin{array}{l}\text { Moderada (úmida), lig. plástico e } \\
\text { pegajoso (molhada) }\end{array}$ \\
\hline BA & $35-60$ & $2,5 \mathrm{YR} 4 / 8$ & $\begin{array}{c}\text { Granular, estrutura forte, pequena a muito } \\
\text { pequena }\end{array}$ & $\begin{array}{l}\text { Moderada (úmida), lig. plástico e } \\
\text { pegajoso (molhada) }\end{array}$ \\
\hline $\mathrm{Bw}$ & $60+$ & $2,5 Y 5 / 8$ & $\begin{array}{c}\text { Granular, estrutura forte, pequena a muito } \\
\text { pequena }\end{array}$ & $\begin{array}{c}\text { Friável (úmida), lig. plástico e lig. } \\
\text { pegajoso (molhada) }\end{array}$ \\
\hline
\end{tabular}


Portanto, os solos estudados são macios quando secos e altamente friáveis quando úmidos (Tabela 7). Todavia, a estrutura destes solos, quando intensamente mecanizados, pode ser danificada, levando à redução da porosidade e, consequentemente, à formação de uma camada compactada (Araújo et al. 2007).

\subsubsection{Atributos físicos}

A análise granulométrica dos solos evidencia altos teores de argila variando entre 550 a $630 \mathrm{~g} \mathrm{~kg}^{-1}$ (Tabela 8). De maneira geral, os valores da argila tendem a aumentar nos horizontes $\mathrm{B}$, porém em todos os perfis, não foi constatada a presença de gradiente textural B/A. Verifica-se ainda o predomínio da fração argila em relação às frações silte e areia, em todos os perfis estudados. Os teores de silte foram, em média, de $320 \mathrm{~g} \mathrm{~kg}^{-1}$, enquanto que os de areia variaram de 20 a $120 \mathrm{~g} \mathrm{~kg}^{-1}$.

Mesmo com os teores relativamente elevados de silte, a relação silte/argila do horizonte Bw variou de 0,5 a 0,7, sendo a menor relação observada em P1 e a maior em P3, que possui teores de silte maiores. Segundo a Sociedade Brasileira de Ciência do Solo SiBCS (EMBRAPA, 2013) valores dessa relação silte/argila inferiores a 0,6, em horizontes que apresentam textura argilosa, indicam elevado grau de intemperismo, como os valores encontrados ficaram próximos ao estipulado, pode-se enquadrar os solos estudados na definição de Bw.

Os valores de Ds foram menores que $1 \mathrm{~g} \mathrm{~cm}^{-3}$, sendo os menores valores observados nos horizontes superficiais, em razão dos maiores teores de matéria orgânica. Klein \& Libardi (2000) determinaram a faixa de umidade do solo menos limitante ao crescimento das plantas, encontrando a densidade de $1,08 \mathrm{~g} \mathrm{~cm}^{-3}$, para um Latossolo Vermelho. Essa seria a densidade ótima para o máximo de água facilmente disponível, com o mínimo de restrições ao desenvolvimento das plantas. Para Goedert (2005), o nível de sustentabilidade Ds para Latossolos é menor que $1 \mathrm{~g} \mathrm{~cm}^{-3}$. 
Tabela 8. Atributos físicos dos solos da topossequência do Quilombo Mesquita, GO

\begin{tabular}{|c|c|c|c|c|c|c|c|}
\hline \multirow{2}{*}{ Perfil } & \multirow{2}{*}{$\begin{array}{c}\text { Horizonte } \\
\text { diagnóstico }\end{array}$} & \multirow{2}{*}{ Profundidade } & Silte & Areia & Argila & Ds* & \multirow{2}{*}{ silte/argila } \\
\hline & & & \multicolumn{3}{|c|}{ 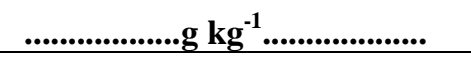 } & $\operatorname{Mg~m} \mathbf{-}^{3}$ & \\
\hline \multirow[t]{2}{*}{$\mathrm{P} 1$} & A & $0-23 \mathrm{~cm}$ & 270 & 100 & 630 & 0,84 & 0,42 \\
\hline & $\mathrm{Bw}$ & $50 \mathrm{~cm}+$ & 290 & 100 & 610 & 0,88 & 0,46 \\
\hline \multirow{2}{*}{$\mathrm{P} 2$} & A & $0-4 \mathrm{~cm}$ & 280 & 120 & 600 & 0,80 & 0,47 \\
\hline & $\mathrm{Bw}$ & $25 \mathrm{~cm}+$ & 320 & 100 & 570 & 0,84 & 056 \\
\hline \multirow{2}{*}{ P3 } & A & $0-20 \mathrm{~cm}$ & 410 & 40 & 550 & 0,79 & 0,74 \\
\hline & $\mathrm{Bw}$ & $60 \mathrm{~cm}+$ & 400 & 20 & 580 & 0,83 & 0,69 \\
\hline
\end{tabular}

*Onde: Ds $=$ densidade de partículas.

\subsubsection{Atributos químicos}

Para todos os perfis, observaram-se valores baixos de $\mathrm{pH}$, entre 4,9 e 5,3, decorrentes da influência do material de origem e grau de evolução pedogenética dos solos, não sendo verificada grande variação de $\mathrm{pH}$ entre horizontes (Tabela 9). Todos os solos foram classificados como ácidos (EMBRAPA, 2011). Ademais, esses solos apresentaram horizonte A com elevada acidez potencial $(\mathrm{H}+\mathrm{Al})$, onde $\mathrm{o} \mathrm{H}^{+}$foi o cátion predominante no complexo sortivo, com valores variando entre 1,7 a $7,8 \mathrm{cmol}_{\mathrm{c}} \mathrm{dm}^{-3}$, devido em grande parte a matéria orgânica do solo, já que o teor de Al foi muito baixo.

No perfil 3, o valor de Ca no horizonte A se destacou $\left(2,4 \mathrm{cmol}_{\mathrm{c}} \mathrm{kg}^{-1}\right)$, em relação aos demais solos (P1 e P2), que apresentaram valor de cálcio cerca de dez vezes menor que o encontrado em P3. O valor de Mg também foi maior em P3. Ademais, os maiores teores de $\mathrm{K}$ foram observados nas camadas superficiais em todos os perfis (Tabela 9), porém, especialmente nos perfis sob cerradão (P2 e P3), onde os valores de K estiveram acima do descrito por Raij et al. (2001), que é de $0,3 \mathrm{cmol}_{\mathrm{c}} \mathrm{dm}^{-3}$. Para Resende et al. (1997) teores elevados de $\mathrm{K}$ total em Latossolos podem estar sendo influenciados por rochas pelíticas, relativamente mais ricas neste mineral. 
Tabela 9. Atributos químicos dos solos do transecto estudado do Quilombo Mesquita - GO

\begin{tabular}{|c|c|c|c|c|c|c|c|c|c|c|c|c|c|c|}
\hline \multirow{3}{*}{ Perfil } & \multirow{3}{*}{ Hor. } & \multirow{3}{*}{$\begin{array}{c}\mathrm{pH} \\
\mathrm{H}_{2} \mathrm{O}\end{array}$} & \multicolumn{7}{|c|}{ Complexo Sortivo } & $\mathbf{V}^{*}$ & $\mathbf{m}^{*}$ & \multirow{3}{*}{$\begin{array}{c}\mathrm{P} \\
\mathrm{mg} \mathrm{kg}^{-1}\end{array}$} & \multirow{3}{*}{$\begin{array}{c}\text { CTC } \\
\mathrm{cmol}_{\mathrm{c}} \mathrm{kg}^{-1} \\
\end{array}$} & \multirow{3}{*}{$\begin{array}{l}\text { COT } \\
\mathrm{g} \mathrm{kg}^{-1} \\
\end{array}$} \\
\hline & & & $\mathrm{Ca}^{2+}$ & $\mathrm{Mg}^{2+}$ & $\mathbf{K}^{+}$ & $\mathrm{Al}^{3+}$ & $\mathbf{H}^{+}$ & SB* & $\mathbf{T}^{*}$ & & & & & \\
\hline & & & \multicolumn{7}{|c|}{ 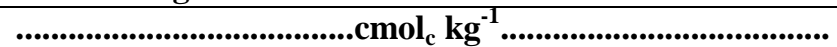 } & \multicolumn{2}{|c|}{...........\%.......... } & & & \\
\hline \multirow[t]{2}{*}{ P1 } & $\mathrm{A}$ & 5,0 & 0,2 & 0,2 & 0,3 & 0,4 & 6,4 & 0,7 & 7,5 & 9,0 & 36,0 & 2,5 & 1,1 & 34 \\
\hline & $\mathrm{Bw}$ & 5,1 & 0,1 & 0,1 & 0,0 & 0,0 & 1,8 & 0,2 & 2,0 & 14,0 & 0,0 & 1,5 & 0,2 & 11 \\
\hline \multirow[t]{2}{*}{$\mathrm{P} 2$} & A & 5,0 & 0,2 & 0,2 & 0,4 & 0,5 & 7,8 & 0,8 & 9,1 & 9,0 & 38,0 & 2,3 & 1,3 & 32 \\
\hline & $\mathrm{Bw}$ & 4,9 & 0,1 & 0,1 & 0,1 & 0,0 & 2,5 & 0,3 & 2,8 & 11,0 & 0,0 & 1,8 & 0,3 & 10 \\
\hline \multirow[t]{2}{*}{ P3 } & A & 5,3 & 2,4 & 0,6 & 0,5 & 0,1 & 7,0 & 3,5 & 10,6 & 33,0 & 3,0 & 2,6 & 3,6 & 34 \\
\hline & $\mathrm{Bw}$ & 5,3 & 0,7 & 0,2 & 0,1 & 0,0 & 1,7 & 1,0 & 2,7 & 37,0 & 0,0 & 1,9 & 1,0 & 11 \\
\hline
\end{tabular}

*Onde: Hor: horizontes diagnósticos; SB: soma de bases; T: CTC potencial; V: saturação por bases; m: saturação por alumínio; COT: carbono orgânico total e MO: matéria orgânica. 
Verifica-se ainda que, todos os íons constituintes do complexo sortivo decrescem com a profundidade. Os valores da soma de bases (SB) variaram entre 0,2 e $3,5 \mathrm{cmol}_{\mathrm{c}} \mathrm{kg}^{-1}$ (Tabela 9) e os de saturação por bases (V) ficaram entre 9 e 37\%, caracterizando os solos como distróficos, conforme EMBRAPA (2011), todavia, vislumbra-se uma ligeira melhoria na fertilidade do cerradão, localizado no ponto $\mathrm{P} 3$, apresentando $\mathrm{V}$ maior do que em P1 (cerrado sensu stricto).

Os valores da CTC variam de 3,6 a 0,2 cmolc $\mathrm{kg}^{-1}$, o que indica o predomínio óxidos de ferro. Para Corrêa et al. (2008), os óxidos de Fe, principalmente hematita e goethita, estão intimamente relacionados com os fenômenos de estruturação e agregação dos solos, podendo conferir-lhes características desejáveis, tais como maior permeabilidade à água e maior resistência

Os teores de $\mathrm{P}$ foram baixos em todos os solos. $\mathrm{O}$ valor baixo de fósforo remanescente, principalmente na camada mais profunda, define uma elevada capacidade de adsorção do nutriente, tornando-o indisponível para as plantas (Alvares et al, 1999). Para todos os perfis, verificou-se o decréscimo dos valores de carbono orgânico (COT) em profundidade, apresentando valores médios em todos os perfis de $33 \mathrm{~g} \mathrm{~kg}^{-1}$ de COT nos horizontes superficiais e de $15 \mathrm{~g} \mathrm{~kg}^{-1}$ nos subsuperficiais.

Os atributos químicos do solo do perfil 3, especialmente, $\mathrm{Ca}, \mathrm{Mg}, \mathrm{SB}, \mathrm{V}$ e CTC foram elevados, discordando a expectativa generalizada sobre a elevada acidez e a baixa fertilidade de solos sob clima tropical úmido, conforme verificado por Lopes (1984) e Furley, (1999). Vale constar que esse solo apresentou teor de COT semelhante aos demais solos dos perfis 1 e 2, isso indicaria a possibilidade da existência na área relativa ao perfil 3 de material de origem proveniente de estratos de litogias pelito-carbonatada da unidade geológica MPpa4, existente no Quilombo Mesquita, a qual conferiu uma fertilidade diferenciada a esse solo. 
A quantificação dos micronutrientes nos solos estudados pode ser verificada nos dados na tabela 10, que demonstram maiores valores desses nutrientes nos horizontes superficiais (Sousa \& Lobato, 2004). No geral, o nível de boro foi considerado baixo, enquanto o zinco foi considerado médio, o que pode ser explicado pelas características do material de origem. Os teores de manganês foram considerados altos, enquanto que o de cobre foi alto em P1 e P2 e médio para P3. Já o nível de ferro foi considerado alto para P1 e P2 e médio para P3. Para Alvares et al. (1999), elevados teores de Fe pode levar a riscos de fitotoxidade. No entanto, por se tratar de materiais bastante resistentes ao intemperismo, era de se esperar níveis elevados de compostos de ferro neste solo.

Tabela 10. Micronutrientes dos solos do transecto estudado do Quilombo Mesquita - GO

\begin{tabular}{|c|c|c|c|c|c|c|}
\hline \multirow{2}{*}{ Perfil } & Horizonte & B & $\mathbf{Z n}$ & $\mathbf{F e}$ & Mn & $\mathrm{Cu}$ \\
\hline & & \multicolumn{5}{|c|}{......................................mg kg kg $^{-1}$...................................... } \\
\hline \multirow[t]{2}{*}{ P1 } & A & 0,2 & 1,6 & 105,1 & 18,5 & 1,4 \\
\hline & $\mathrm{Bw}$ & 0,1 & 0,9 & 34,3 & 3,7 & 1,1 \\
\hline \multirow[t]{2}{*}{ P2 } & A & 0,2 & 1,4 & 129 & 68,7 & 1,9 \\
\hline & $\mathrm{Bw}$ & 0,1 & 1,0 & 46 & 33,6 & 1,4 \\
\hline \multirow[t]{2}{*}{ P3 } & A & 0,2 & 1,2 & 29,2 & 63 & 0,6 \\
\hline & $\mathrm{Bw}$ & 0,1 & 1,1 & 33,9 & 16,2 & 0,7 \\
\hline
\end{tabular}

Os solos estudados são de baixa fertilidade, o que torna a sua manutenção altamente dependente da ciclagem biogeoquímica de nutrientes. Nesse contexto, a dinâmica da matéria orgânica assume papel essencial na manutenção do equilíbrio dinâmico no sistema solo-planta (Selle, 2007). Portanto, apesar de tratar-se de um solo muito argiloso (acima de $60 \%$ de argila), a fração coloidal mineral contribui relativamente pouco para os sítios de troca, condição essa típica dos latossolos planos e altamente intemperizados, nos quais comumente predominam as argilas de baixa atividade (EMBRAPA, 2013). 


\subsection{CONCLUSÕES}

$\checkmark$ As terras do Quilombo Mesquita distribuem-se em seis classes de aptidão agrícola nos níveis de manejo A, B e C, representadas pelas classes 2(b)c, 3(a)b, 3(b)c, 4p, 5(n) e 6.

$\checkmark$ Verificou-se que em mais da metade da área do Quilombo Mesquita é praticada alguma atividade agrícola, seja com cultivos agrícolas, ou pastagens, havendo muitas áreas com solos expostos.

$\checkmark$ Boa parte das áreas de uso restrito para pastagem natural (classe 5n) e sem aptidão agrícola (classe 6) estão sendo utilizadas para atividade agrícola;

$\checkmark$ Os Latossolos constituem os solos de maior ocorrência no Quilombo Mesquita, sendo os solos estudados classificados como Latossolo Vemelho distrófico típico - LVd, desenvolvido a partir de material de natureza psamo-pelítica.

\subsection{REFERÊNCIAS BIBLIOGRÁFICAS}

ALVAREZ, V.H.; NOVAIS, R.F.; BARROS, N.F.; CANTARUTTI, R.B. \& LOPES, A.S. Interpretação dos resultados das análises de solos. In: RIBEIRO, A.C.; GUMARÃES, P.T.G. \& ALVAREZ V., V.H., eds. Recomendações para o uso de corretivos e fertilizantes em Minas Gerais. Viçosa, MG, CFSEMG, 1999, p.25-32.

ARAUJO, R. et al. Qualidade de um solo sob diferentes usos e sob cerrado nativo. Revista Brasileira de Ciência do Solo, Viçosa, v.31, 2007, p. 1099-1108.

ASSIS, R. L.; LANÇAS, K. P. Agregação de um NitossoloVermelho Distroférrico sob sistemas de plantio direto, preparoconvencional e mata nativa. Engenharia Agrícola, v. 30, n. 1, 2010, p. 58-66.

BARROS, J. S. Associação entre solos e vegetação nas áreas de transição cerrado-caatingafloresta na bacia do Parnaíba: sub-bacia do rio Longá-PI. Universidade de Brasília. 2012. Tese (Doutorado em Ecologia).

BRADY, N.C.; WEIL, R.R. Elements of the nature and properties of Soils. New Jersey: Pearson Education, 2010. 
BRASIL. Ministério das Minas e Energia. Projeto RADAMBRASIL. Folha SD.22 Goiás: geologia, geomorfologia, pedologia, vegetação, uso potencial da terra. (Levantamento de Recursos Naturais, 25). Rio de Janeiro, 1981. 640 p.

BRASIL. Ministério do Meio Ambiente. Biodiversidade brasileira: avaliação e identificação de áreas e ações prioritárias para conservação, utilização sustentável e repartição de benefícios da biodiversidade brasileira. Brasília: Ministério do Meio Ambiente/Secretaria de Biodiversidade e Florestas, 2002.

BRAUN O.P.G., MARTINS M. \& OLIVEIRA W.J. Continuidade das seqüências rifeanas sob a Bacia do São Francisco constatada por levantamentos geofísicos em Minas Gerais. In: Simpósio sobre o Cráton do São Francisco, 2., 1993. Salvador. Anais... Salvador, Sociedade Brasileira de Geologia, p. 164-166.

BUSTAMANTE, M.M.C., CORBEELS, M., SCOPEL, E., ROSCOE, R. Soil carbon storage and sequestration potential in the cerrado region of Brazil. In: Carbon Sequestration in Soils of Latin America. The Haworth Press, 2006, Inc. pp 285-304.

CAMPOS, J.E.G.; DARDENNE, M.A.; FREITAS-SILVA, F.H.; MARTINS-FERREIRA, M.A.C. Geologia do Grupo Paranoá na porção externa da Faixa BrasíliaBraz. J. Geol., São Paulo, 2013, 43(3): 461-476.

CAUME, D. J. A agricultura familiar no Estado de Goiás. Goiânia: Editora da UFG, 1997.

CHAGAS, C.S.; CURI, N.; DUARTE, M.N.; MOTTA, P.E.F. \& LIMA, J.M. Orientação das camadas de rochas metapelíticas pobres na gênese de Latossolos sob cerrado. Pesq. Agropec. Bras., 32:539-548, 1999.

CORNELL RM, SCHWERTMANN U. The iron oxides. Weinheim: VCH Verlag. 1996. $570 \mathrm{p}$.

CORREAA, M. M. et al. Caracterização física, química, mineralógica e micromorfológica de horizontes coesos e fragipãs de solos vermelhos e amarelos do ambiente Tabuleiros Costeiros. Revista Brasileira de Ciência do Solo, v. 32, n. 01, 2008, p. 297-313.

CPRM/SIC-SGM. Geologia do Estado de Goiás e do Distrito Federal. Texto explicativo do mapa geológico. Escala 1:500.000. Goiânia. 2008, 143p. 
EMBRAPA - Empresa Brasileira de Pesquisa Agropecuária, 2016. <http://www.agritempo.gov.br/agritempo/index.jsp. Acesso em 27 Mar 2016.

EMBRAPA. Manual de métodos de análises de solo. 2. ed. Rio de Janeiro: Centro Nacional de Pesquisa de Solos, 2011. 212 p.

EMBRAPA. Sistema Brasileiro de Classificação de Solos. Rio de Janeiro: Centro Nacional de Pesquisa de Solos, 2013. 306 p

FARIA A. \& DARDENNE M.A. Estratigrafia do Grupo Paranoá na região de Alto Paraíso de Goiás-São João D’Aliança - GO. In: SBG, Simp. Geol. Centro-Oeste, 5, Anais, 1995, p. 7577.

FCP. Fundação Cultural Palmares. Disponível em: www.palmares.gov.br/. Acesso em maio de 2016.

FERNANDES, A.H.B.M.; SALES, S.M.; FERNANDES, F.A.; CRISPIM, S.M.A. Estoques de carbono do estrato arbóreo de Cerrados no pantanal da Nhecolândia. Comunicado técnico 68. Dezembro, 2008: Corumbá, MS.

FURLEY, P. A. The nature and diversity of neotropical savanna vegetation with particular reference to the Brazilian cerrados. Global Ecology and Biogeography. 8, 1999, 223-241.

GOEDERT, W. J. (Ed.). Solos dos cerrados: tecnologias e estratégias de manejo. Planaltina: Embrapa-CPAC, 1987.

GOMES, J.B.V.; CURI, N.; MOTTA, P.E.F.; KER, J.C.; MARQUES, J.J.G.S.M.; SCHULZE, D.G. Análise de componentes principais de atributos físicos, químicos e mineralógicos de solos do Bioma Cerrado. Revista Brasileira de Ciências do Solo, v.28, 2004. p.137-153.

GOODLAND, R. Oligotrofismo e alumínio no cerrado. 1971. p. 44-60. In: Ferri, M. G. III Simpósio sobre o cerrado. EdUSP, São Paulo.

HIRANO, C.; CHAGAS, C.S.; AMARAL, F.C.S.; SOUSA NETO, N.C.; PEREIRA, N.R.; CUNHA, M.S.P. Aptidão •agrícola, das terras do Estado de Goiás, por Chyozo Hirano e outros. Rio de Janeiro, 1989. 40p. ilust. (EMBRAPA-SNLCS. Boletim de Pesquisa, 39). 
KLEIN, V.A.; LIBARDI, P.L. A faixa de umidade menos limitante ao crescimento vegetal e a sua relação com a densidade do solo ao longo de um perfil de um Latossolo roxo. Ciência Rural. v.30; p.959-964, 2000.

LAGO, W.N.M.; LACERDA, M.P.C; NEUMANN, M.R.B.; BORGES, T.D. Ocupação e adequação do uso das terras na microbacia do Ribeirão Extrema, Distrito Federal - Parte I. 1Revista Brasileira de Engenharia Agrícola e Ambiental v.16, n.3, 2012, p.289-296.

LATRUBESSE, E.M.; CARVALHO, T.M.C. Geomorfologia do Estado de Goiás e Distrito Federal. GOIÁS (Estado). Secretaria de Indústria de Comércio. Superintendência de Geologia e Mineração. 2006, 128 p.

LEI FEDERAL nº 12.651/2012. Novo código Florestal.

LEPSCH, I.F. 19 lições de pedologia. São Paulo: Oficina de textos, 2011.

LEPSCH, I.F.; OLIVEIRA, V A. 5 - Solos. In: Galinkin, M. (Ed.). GeoGoiás 2002. Goiânia: Agência Ambiental de Goiás: Fundação Cebrac: PNUMA: Semarh, 2003. p. 122-129. OLIVEIRA, V.A.; CALIL, P.M.; SILVA, M.T.G.; NOGUEIRA, S.A.J.; AZEVEDO, W.R.;ALMEIDA, L.L.C. Diagnóstico agroambiental do entorno do Parque Nacional das Emas. Goiânia: Agência Goiana de Desenvolvimento Rural e Fundiário, 2003. Resende, M. et al. Pedologia: base para distinção de ambientes. Viçosa: Neput, 1999. Ribeiro, J. F.; Walter, B. M. T. Fitofisionomias do bioma cerrado. In: Sano, S. M.; Almeida, S. P. (Eds.). Cerrado: ambiente e flora. Planaltina: Embrapa-CPAC, 1998. p. 87-166.

LOPES, A.S. Solos sob cerrado - Características, propriedades e manejo. 2.ed. Piracicaba, Potafós, 1984. 162p.

MARIMON JUNIOR, B.H.; HARIDASAN, M. Comparação da vegetação arbórea e características edáficas de um cerradão e um cerrado sensu stricto em áreas adjacentes sobre solo distrófico no leste de Mato Grosso, Brasil. Acta Botanica Brasilica, v. 19, 2005, p. 913 926.

MATOS, L.V.; KER, J.C.; CARDOSO, I.M.; LANI, J.L.; REYNAUD, C.E.G.; O conhecimento local e a etnopedologia no estudo dos agroecossistemas da Comunidade 33 Quilombola de Brejo dos Crioulos. Soc. \& Nat., Uberlândia, v. 26, 2014, p.497-510. 
MAZOYER, M. \& ROUDART, L. História das agriculturas no mundo: do neolítico à crise contemporânea. São Paulo, UNESP, 2010. 568 p.

MEDEIROS, D.A. Métodos de amostragens no levantamento da diversidade arbórea do cerradão da Estação Ecológica de Assis. Escola Superior de Agricultura Luiz de Queiroz, 2004. 85p. Dissertação.

NETTO, F.M.; DANELON, J. R.B.; RODRIGUES, S.C. Avaliação da qualidade da água e do uso da terra da Bacia hidrográfica do córrego Terra Branca - Uberlândia - MG. Revista Geográfica Acadêmica. V. 5, n.2. XII, 2011.

PORTUGAL, A.F.; FONTES, L.E.F.; LANI, J.L.; SCHAEFER, C.E.R.G. Alterações em propriedades físicas do solo em ecossistemas de floresta após a implantação de pastagem no extremo oeste do Acre. In: ARAÚJO, E. A.; LANI, J. L. Uso sustentável de ecossistemas de pastagens cultivadas na Amazônia Ocidental. Rio Branco: SEMA, 2012. 142 p.

RABELO, C.G.; FERREIRA, M.R.; ARAÚJO, J.V.G.; STONE, L.F; SILVA, S.C.; GOMES, M.P. Influência do uso do solo na qualidade da água no bioma cerrado: um estudo comparativo entre bacias hidrográficas no Estado de Goiás, Brasil. Revista Ambiente e Água - An Interdisciplinary Journal of Applied Science: v.4, n.2, 2009, p. 172-187.

RAIJ, B. van; ANDRADE, J.C.; CANTARELLA, H.; QUAGGIO, J.A. Análise química para avaliação da fertilidade de solos tropicais. Campinas Instituto Agronômico, 2001. 285p.

RAMALHO-FILHO, A.; BEEK, K. J. Sistema de avaliação da aptidão agrícola das terras. 3. ed. Rio de Janeiro: EMBRAPA-CNPS, 1995. 65 p.

RENNER, Rosana Maria. Sequestro de carbono e a viabilização de novos reflorestamentos no Brasil. 2004. Dissertação (Mestrado em Ciências Florestais).

RESENDE, M.; CURI, N.; KER, J.C. \& REZENDE, S.B. Mineralogia de solos brasileiros: Interpretação e aplicações. Lavras, Universidade Federal de Lavras, 2005. 192p.

RESENDE, R.F.; CURI, N.; REZENDE, S.B. de; CORRÊA, G.F. Pedologia: base para distinção de ambientes. 2.ed. Viçosa : Núcleo de Estudos e Planejamento de Uso da Terra, 1997. 367p. 
RIBEIRO, J. F.; WALTER, B. M. T. As principais fitofisionomias do bioma Cerrado in: SANO, S. M.; DE ALMEIDA, S. P., RIBEIRO, J. F. Cerrado Ecologia e Flora. Brasília: Embrapa Informação Tecnológica, 2008, 406 p.

RIBEIRO, M.S. O tratamento contábil dos créditos de carbono. Ribeirão Preto: USP, 2005. 17p. Tese (Livre docência apresentada à Faculdade de Economia), FEA, Universidade de São Paulo, 2006.

RODRIGUES, R.F.; ARAÚJO, G.M. Estrutura da vegetação e características edáficas de um Cerradão em solo distrófico e em solo mesotrófico no Triângulo mineiro. Biosci. J., Uberlândia, v. 29, n. 6 , 2013, p. 2013-2029.

RTID/INCRA - Relatório Técnico de Identificação e Delimitação do Quilombo Mesquita. INCRA: Instituto Nacional de Colonização de Reforma Agrária. Publicado no Diário Oficial da União (DOU) de 29 e 30/08/2011.

SANO, E. E. ; ROSA, R.; BRITO, J. L. S.; FERREIRA, L. G. Land cover mapping of the tropical savanna region in Brazil. Environmental Monitoring and Assessment (Print), v. 166, p. 113-124, 2010.

SANTOS, R. D.; LEMOS, R.C.; SANTOS, H.G.; KER, J.C.; ANJOS, L.H. Manual de descrição e coleta de solos no campo. 5e.ed Viçosa. Sociedade Brasileira de Ciência do solo, 2005.100p.

SCHAEFER, C.E.G.R.; FABRIS, J.D. \& KER, J.C. Minerals in the clay fraction of Brazilian Latosols (Oxisols): A review. Clay Miner., 43, 2008, p. 137-154.

SELLE, G. L. Ciclagem de nutrientes em ecossistemas florestais. Bioscience Journal, v. 23, n. 4, 2007, p. 29-39.

SIEG. Sistema Estadual de Informação do Goiás. Disponível em: http://www.sieg.go.gov.br/. Acesso em 01 Junho de 2016.

SILVA, E. B. da; NOGUEIRA, R. M.; UBERTI, A. A. A. Avaliação da aptidão agrícola das terras como subsídio ao assentamento de famílias rurais, utilizando sistemas de informação geográfica. Revista Brasileira de Ciência do Solo, Viçosa, MG, v. 34, n. 6, nov/dez. 2010, p. 1977-1990. 
SILVA, M.L.N.; BLANCANEAUX, P.; CURI, N.; LIMA, J.M.; MARQUES, J.J.G.S.M. \& CARVALHO, A.M. Estabilidade e resistência de agregados de Latossolo Vermelho-Escuro cultivado com sucessão milho-adubo verde. Pesq. Agropec. Bras., 33, 1998, 97-103 p.

SILVA, M.L.N.; CURI, N.; MARQUES, J.J.G.S.M.; LIMA, L.A.; FERREIRA, M.M. \& LIMA, J.M. Resistência ao salpico provocado por impacto de gotas de chuva simulada em Latossolos e sua relação com características químicas mineralógicas. Ci. Prát., 19, 1995, 176$182 p$.

SILVA, M.L.N.; FREITAS, P.L.; BLANCANEAUX, P.; CURI, N.\& LIMA, J.M. Relação entre parâmetros de chuva e perdas de solo e determinação da erodibilidade de um Latossolo Vermelho-Escuro em Goiânia (GO). R. Bras. Ci. Solo, 21, 1997, 131-137p.

SILVA, R.B.M.; FRANCELINO, M.R.F.; MOURA, P.A.; MOURA, T.A.; PEREIRA, M.G.; OLIVEIRA, C.P. Relação solo/vegetação em ambiente de cerrado sobre influência do grupo Urucuia. Ciência Florestal, Santa Maria, v. 25, n. 2, 2015, p. 363-373.

SOUSA, D.M.G.; LOBATO, E. Cerrado: correção do solo e adubação. 2 ed. Brasília: Embrapa Cerrados, 2004. 416 p.

SPERA, S.T.; REATTO, A.; MARTINS, E.S.; CORREIA, J.R.; CUNHA, T.J.F. Solos arenoquartzosos no cerrado: problemas, características e limitações ao uso. Planaltina: Embrapa Cerrados, 1999. (Documentos, 7).

SPERA, S.T.; REATTO, A.; MARTINS, E.S.; CORREIRA, J.R. Atributos físicos de solos e distribuição das fitofisionomias de Cerrado na bacia hidrográfica do Rio Jardim - DF. Boletim de Pesquisa e Desenvolvimento, 146, 2005, p. 1-18.

TEDESCO, J. C. e outros. Agricultura familiar: realidades e perspectivas. UPF. 3. ed. Passo Fundo, 2001.

USGS. Science for a changing world. Disponível em: https://www.usgs.gov/. Acesso em 01 de Junho de 2016.

VILLELA, F.N.J. NOGUEIRA, C. Geologia e geomorfologia da estação ecológica Serra Geral do Tocantins. Biota Neotrop., vol. 11, n. 1. 2011, p. 217-229. 


\section{CAPÍTULO 2}

\section{Atributos do solo sob diferentes usos da terra praticados por agricultores quilombolas em Goiás \\ RESUMO}

O objetivo do trabalho foi verificar o impacto nos atributos do solo devido a diferentes usos de um Latossolo Vermelho da região do Cerrado de Goiás, realizados por agricultores familiares quilombolas. As áreas estudadas sob Cerradão são: cerradão; pastagem de braquiárias; plantio convencional de grãos1; tangerina com consórcio; e sob Cerrado sensu stricto são: cerrado; pastagem de plantas nativas e braquiárias; plantio convencional de grãos2; tangerina sem consórcio. As amostras de solo foram coletadas nas profundidades de 0-10 e 10-20 cm e realizadas determinações de atributos físicos, químicos e biológicos. Os usos da terra com sistema de produção convencional (plantio convencional de grãos 1 e 2; tangerina sem consórcio e pastagem de braquiárias) promoveram alterações nos atributos estudados, sendo que o uso da terra com sistema de produção conservacionista (tangerina com consórcio) foi o que menos impactou os atributos físicos, químicos e biológicos. A aplicação da análise redundância canônica ressaltou na profundidade de 0-10 cm, maior semelhança entre a tangerina com consórcio e o plantio convencional de grão 1, enquanto que, os demais usos da terra, com exceção do cerradão, agruparam-se. Na profundidade de 10-20 cm, a tangerina sem consórcio e o cerradão não se agruparam com os demais usos da terra, diferenciando-se dos demais manejos. A análise de redundância também revelou que os atributos (Ds, Pt, K, Mg, P, pH, H+Al e CTC) relacionaram-se significativamente aos atributos biológicos que discriminaram os usos da terra adotados pelos quilombolas.

Palavras-chave: qualidade do solo, manejo conservacionista, análise multivariada, Latossolos, comunidades tradicionais. 


\title{
Properties of soil under different land uses practiced by farmers Quilombolas in Goiás
}

\begin{abstract}
The aim of the study was to assess the impact on soil properties due to different uses of an Latosols of Goiás Cerrado region, carried out by quilombolas farmers. The areas studied under Cerradão are: cerradão; Brachiaria pasture; Conventional planting grain 1; tangerine with the consortium; and under Cerrado sensu stricto are: cerrado sensu stricto, pasture native and Brachiaria plants; conventional planting grain 2; tangerine without consortium. Soil samples were collected at 0-10 and 10-20 cm and made determinations of physical, chemical and biological attributes. Land uses with conventional production systems (conventional planting cultivation 1 and 2, tangerine without consortium and Brachiaria pasture) promoted changes in attributes studied, and the use of land with conservation production system (tangerine with consortium) was the less impacted the physical, chemical and biological attributes. The application of canonical redundancy analysis underscored the depth of 0-10 $\mathrm{cm}$, greater similarity between the tangerine with consortium and conventional planting grain 1, and other uses, except cerradão, grouped themselves. In the depth of 10-20 cm, tangerine without consortium not grouped with other land uses, differentiating itself from other managements. Redundancy analysis also revealed that the attributes (Ds, $\mathrm{Pt}, \mathrm{K}, \mathrm{Mg}, \mathrm{P}, \mathrm{pH}, \mathrm{H}$ $+\mathrm{Al}$ and $\mathrm{CTC}$ ) related significantly to the biological features that discriminate land uses adopted by the quilombolas.
\end{abstract}

Keywords: soil quality, conservation management, multivariate analysis, Latosols, traditional communities. 


\subsection{INTRODUÇÃO}

O solo é à base da produção agrícola ou florestal e seus atributos são afetados pelo tipo de uso e manejo adotados, sendo a magnitude das alterações dependentes do tempo de uso dos solos e das condições edafoclimáticas da região (D’Andréa et al., 2002). A adoção de práticas conservacionistas do solo tende a contribuir para a manutenção ou melhoria da sua qualidade e do ambiente e para o aumento da produtividade das culturas em longo prazo (Piagnataro Netto et al., 2009; Nogara Neto et al., 2011; Wendling et al., 2012; Costa et al., 2013, Silva et al., 2014).

A relação entre sistemas de manejo e qualidade do solo pode ser avaliada por meio das alterações ocorridas em seus atributos físicos, químicos e biológicos e quantificada por meio de indicadores da qualidade do solo (Torres et al., 2015), que atendam à condição de sensibilidade ao manejo numa escala de tempo que permita a verificação de suas alterações (Vezzani \& Mielniczuk, 2009; Audeh et al., 2011). Para Carneiro et al. (2009), a avaliação é complexa e deve ser realizada por um conjunto de indicadores específicos (atributos) e suas inter-relações, já que se tem verificado que indicadores isolados não são suficientes para explicar a perda ou o ganho potencial dos cultivos de determinado solo.

Nos últimos anos, os estudos sobre a qualidade do solo evoluíram significativamente, justificados quase sempre pela necessidade de se avaliar o comportamento de diversos atributos do solo em áreas sob cultivo agrícolas e pastagens (Spera et al., 2009), pois o manejo inadequado do solo pode provocar aumento da densidade, diminuição da macroporosidade e porosidade total, redução de $\mathrm{Ca}^{2+}, \mathrm{Mg}^{2+}, \mathrm{K}^{+}, \mathrm{P}$ e teores de matéria orgânica, bem como da biomassa microbiana e enzimas, dentre outros danos (Pragana et al., 2012; Silva et al., 2014; Godoy et al., 2013; Rambo et al., 2014; Costa et al. 2015, Sales et al., 2016). 
No Brasil, em territórios quilombolas é comum a alteração do meio ambiente natural, seja nas áreas invadidas por terceiros, como naquelas ocupadas por quilombolas, que devido à ausência de politicas públicas de inclusão produtiva, tem tido dificuldades de promover e manter práticas conservacionistas de uso do solo. Diante desse cenário, ocorrem perdas não somente da qualidade do solo, como também de produtividade.

É por isso que Muniz et al. (2011), Cunha et al. (2012), Pragana et al. (2012), Costa et al. (2015), Giácomo et al. (2015), Guimarães et al. (2016) e Sales et al. (2016), avaliando as propriedades físicas, químicas e biológicas de Latossolos submetidos a diferentes manejos, verificaram que em sistemas convencionais de plantio, os solos apresentaram condições físicas, químicas e biológicas inferiores às áreas com manejos mais conservacionistas.

Portanto, a avaliação da qualidade do solo permite prever danos ao ambiente, subsidiar discussões sobre a continuidade de um manejo, descobrindo pontos fortes e fracos, que podem fortalecer as pesquisas sobre a importância da biodiversidade em sistemas de produção, além de contribuir para a readequação de práticas culturais que visem a homeostase do sistema de produção (Doran \& Parkin, 1994; Araújo et al., 2007; Dias et al., 2010).

O objetivo do trabalho foi verificar o impacto nos atributos do solo devido a diferentes usos de um Latossolo Vermelho da região do Cerrado de Goiás, realizados por agricultores familiares quilombolas.

\subsection{MATERIAL E MÉTODOS}

O trabalho foi desenvolvido no Quilombo de Mesquita, localizado na região Centro-Oeste do Brasil, no município da Cidade Ocidental (160 04' 40,79" S e 47 52' 05,51" W), na região leste do Estado de Goiás. De acordo com a classificação de Köppen, o clima da área de estudo é do tipo Cwa, tropical de altitude, com temperatura e precipitação média anual 
de $20^{\circ} \mathrm{C}$ e $1.500 \mathrm{~mm}$ respectivamente, com estação chuvosa iniciando em outubro e terminando em abril e estação seca, de maio a setembro (EMBRAPA, 2016).

O Quilombo Mesquita possui área total de 4.292,8259 ha, com duas fitofisionomias representativas do Bioma Cerrado (Cerradão e Cerrado strictu senso). Cerca de 761,257 ha estão sob posse dos quilombolas e abrangem a área objeto desse estudo. Nessas áreas predominam os Latossolos, os solos mais utilizados agricolamente no Quilombo, os quais são o objeto de estudo da presente tese.

Como os Latossolos utilizados pelos quilombolas estão nas áreas de fitofisionomias Cerradão e Cerrado sensu stricto, a priori seriam selecionadas duas propriedades em cada fitofisionomia, as quais teriam que possuir quatro tipos de usos do solo (pastagem, milho, tangerina e mandioca) semelhantes e mais praticados pelos quilombolas, de acordo com os dados do RTID/INCRA (2011). Porém, devido ao processo de expropriação das terras do Quilombo Mesquita, as famílias produzem em áreas muito pequenas, não sendo encontrados numa única propriedade no Cerradão os usos da terra selecionados. Por isso, foi escolhida uma propriedade no Cerrado sensu stricto e duas no Cerradão, sendo aberto em cada propriedade um perfil, visando à descrição morfológica do solo (conforme relatado no Capítulo 1), para confirmar se os solos possuíam as mesmas características (Latossolo Vermelho distrófico típico - LVd).

Portanto, foram selecionadas três propriedades agrícolas para as amostragens, com distintas condições de uso da terra no mesmo tipo de solo ( $\mathrm{LVd}$ ), porém com vegetação diferente. Assim, selecionaram-se oito tipos de usos do solo (Figuras 13, 14 e 15, 16 e 17), onde as áreas nativas (Cerradão e Cerrado sensu stricto) foram utilizadas como referência, por se tratar de sistemas em equilíbrio e sem histórico de intervenção humana.

Na primeira propriedade agrícola, referente ao Latossolo do Perfil 1, na área sob Cerrado sensu stricto, foram estudados os seguintes usos dos solos (Figuras 13 e 14): CSS 
(Cerrado sensu stricto - área de referencia); PNB (pastagem de plantas nativas e braquiárias); CG2 (plantio convencional de grãos); e TSC (plantio de tangerina sem consórcio), cujos históricos serão detalhados a seguir.

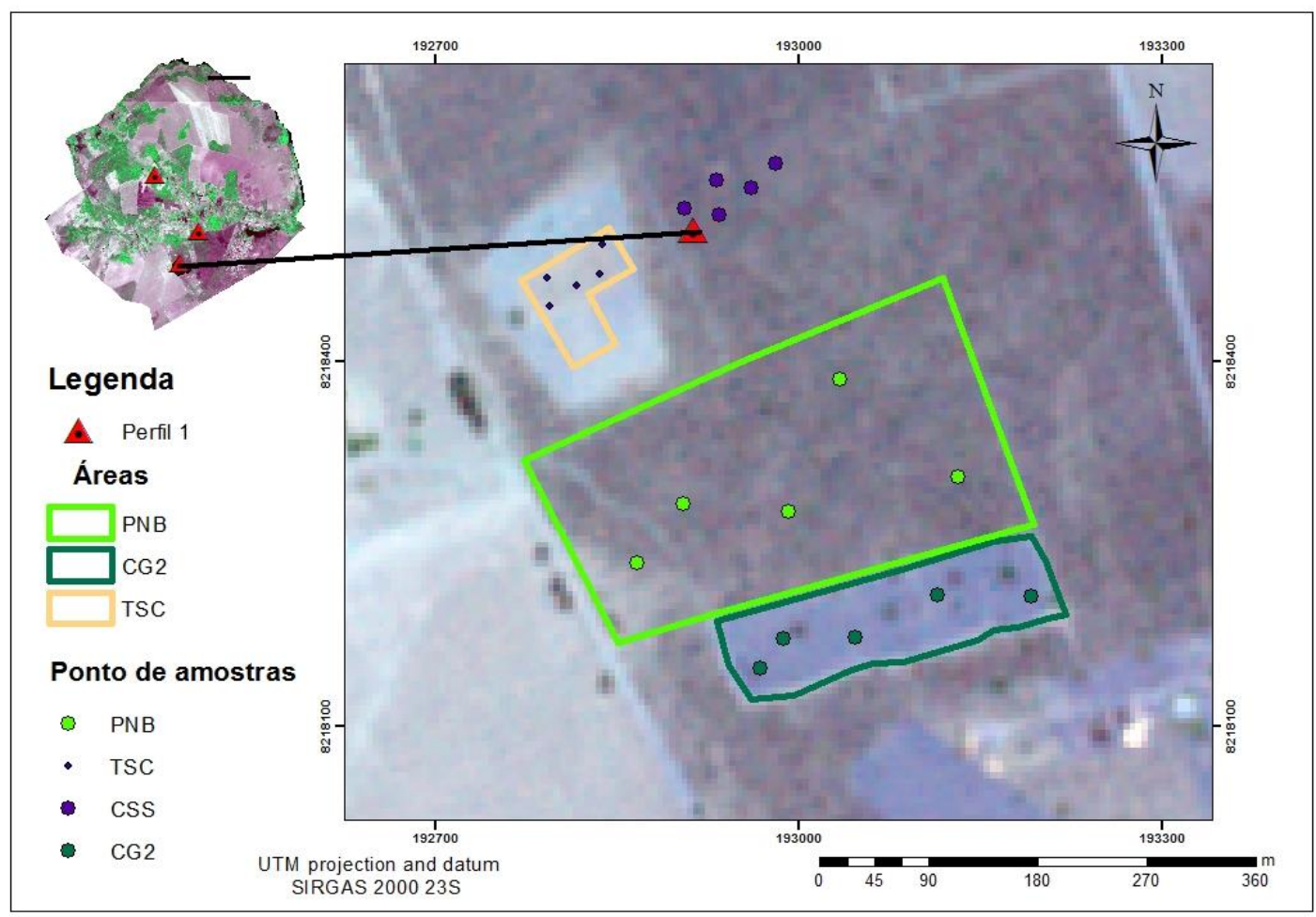

Figura 13. Localização das áreas de diferentes usos do solo e dos pontos de coleta de solos realizados na área de Cerrado sensu stricto, considerando a abertura do Perfil 1 (LVd). Os pontos de amostras foram realizados nos seguintes usos do solo: PNB (pastagem de plantas nativas e braquiárias); TSC (plantio de tangerina sem consórcio); CSS (Cerrado sensu stricto - área de referencia); e CG2 (plantio convencional de grãos).

Os históricos dos usos do solo na área de Cerrado sensu stricto foram:

1. Cerrado nativo (CSS): remanescente de cerrado sensu stricto, apresentando floras do tipo herbácea e lenhosa, típica de formação savana, utilizado como referência e sem qualquer tipo de manejo/exploração. No entanto, é uma área que sofreu queimada esporádica, típica do Bioma Cerrado. Por ser uma área grande, a mesma não foi medida, por isso não há delimitação da área na Figura 4.1. 
2. Pastagem com plantas nativas e braquiárias (PNB): Área de aproximadamente 7 ha. Representa transição entre Cerrado sensu stricto e Campo cerrado, coberta por diversos tipos de gramíneas nativas, bem como por Brachiaria brizantha e Brachiaria decumbens, que invadiram naturalmente a área. As gramíneas encontradas na área possuem potencial forrageiro. É uma área que sofreu queimada igualmente ao ocorrido no cerrado nativo (CSS). Não há pastejo contínuo de bovinos na área.

3. Plantio convencional de grãos (CG2): Área de aproximadamente 2 ha, manejada há 15 anos com plantio de grãos com práticas convencionais de preparo do solo. Inicialmente, foi realizada a correção da acidez da área (1 t/ha de calcário dolomítico), sendo cultivada durante 5 anos com arroz, o qual foi adubado anualmente com o formulado NPK 15-20-25 (750 kg/ha). Nos últimos 10 anos, a área foi cultivada anualmente apenas com milho, tendo sido realizadas gradagens anuais e adubações no plantio com NPK na formulação 4-30-16 (500 kg/ha) e de cobertura com NPK 10-1010 (250 kg/ha). A calagem foi realizada na área apenas uma vez. Há muita presença de plantas daninhas, porém não há palhada no solo.

4. Tangerina sem consórcio (TSC): Área de aproximadamente 0,5 ha, manejada há 5 anos com plantio de tangerina com preparo convencional mínimo do solo. A acidez da área foi corrigida apenas uma vez com 0,5 t/ha de calcário dolomítico. Não houve adubação inicial de plantio. No entanto, é realizada adubação de cobertura na área três vezes ao ano, com o formulado NPK 10-20-25 (250 g/cova) e pelo composto orgânico de lixo, fornecido pelo Serviço de Limpeza Urbana do Distrito Federal (2 litros/cova). A tangerina não é consorciada com outra cultura, estando o solo sempre descoberto, pois as plantas daninhas são eliminadas pelo uso de herbicidas. 

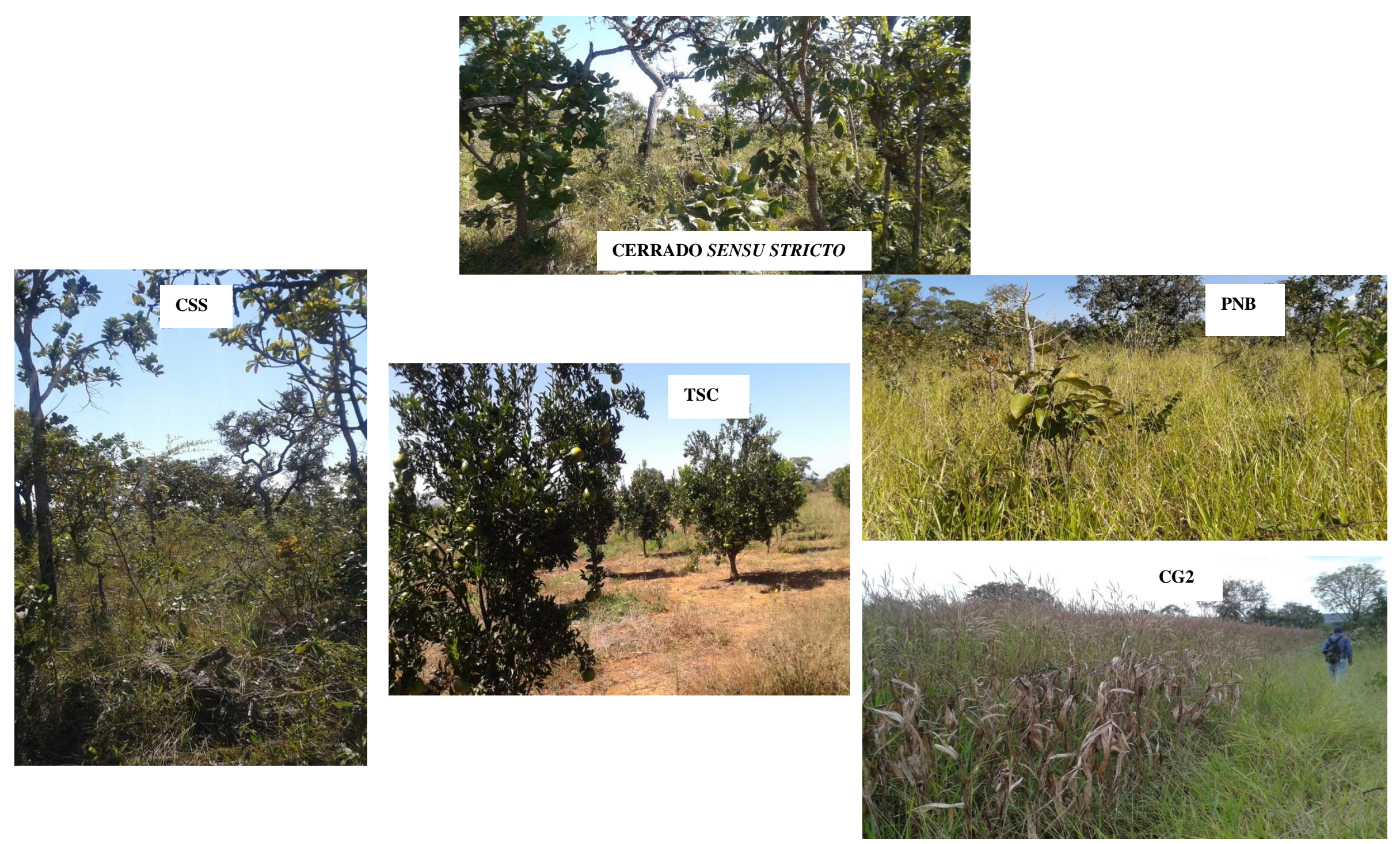

Figura 14. Usos da terra nas áreas sob Cerrado sensu stricto. Onde: CSS: Cerrado sensu stricto, TSC: Tangerina sem consório; PB: pastagem de braquiárias; CG2: Plantio convencional de grãos. 
Na segunda propriedade agrícola, referente ao Latossolo do Perfil 2, na área sob Cerradão, foi estudado o uso do solo (Figuras 15 e 17): PB (pastagem de braquiária).

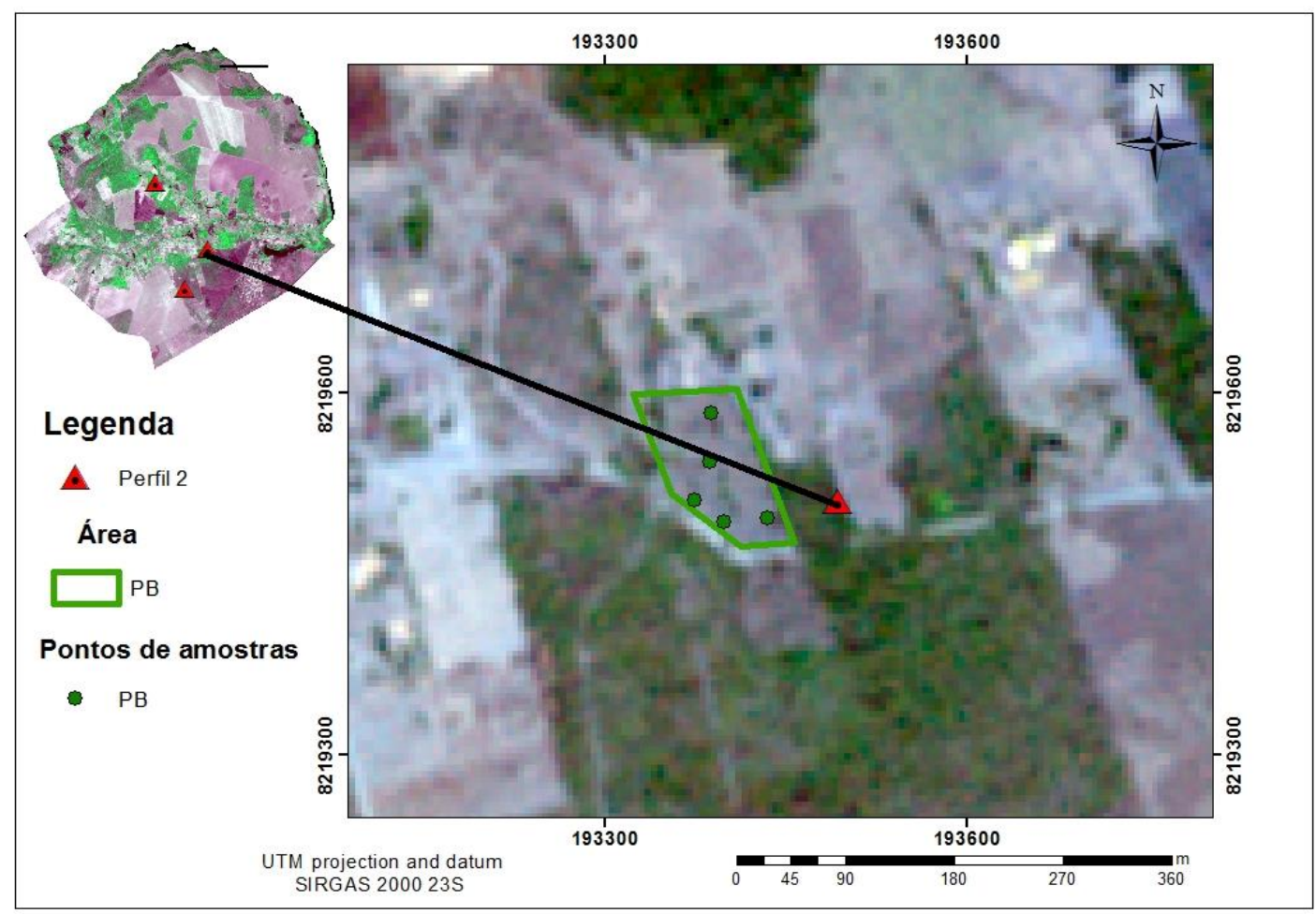

Figura 15. Localização das áreas de diferentes usos do solo e dos pontos de coleta de solos realizados na área de Cerradão, considerando a abertura do Perfil 2 (LVd). Os pontos de amostras foram realizados nos seguintes usos do solo: PB (pastagem de braquiárias).

O histórico do uso do solo na área de Cerradão, referente à segunda propriedade foi:

5. Pastagem de braquiária (PB): Área de aproximadamente 1 ha ocupada por pastagem sem preparo do solo e manejo de fertilidade. Por 20 anos, foi realizada rotação de cultura arroz/feijão/milho/cana-de-açúcar. Nos últimos 15 anos, a área não foi mais manejada, ficando em pousio, momento no qual a Brachiaria decumbens e Brachiaria brizantha invadiram naturalmente o local. Não há pastejo contínuo de bovinos na área.

Na terceira propriedade, referente ao Latossolo do Perfil 3, também na área sob Cerradão, foram estudados os demais usos do solo (Figuras 16 e 17): CER (Cerradão - área 
de referencia); CG1 (plantio convencional de grãos); e TCC (plantio de tangerina com consórcio), cujos históricos foram detalhados a seguir.

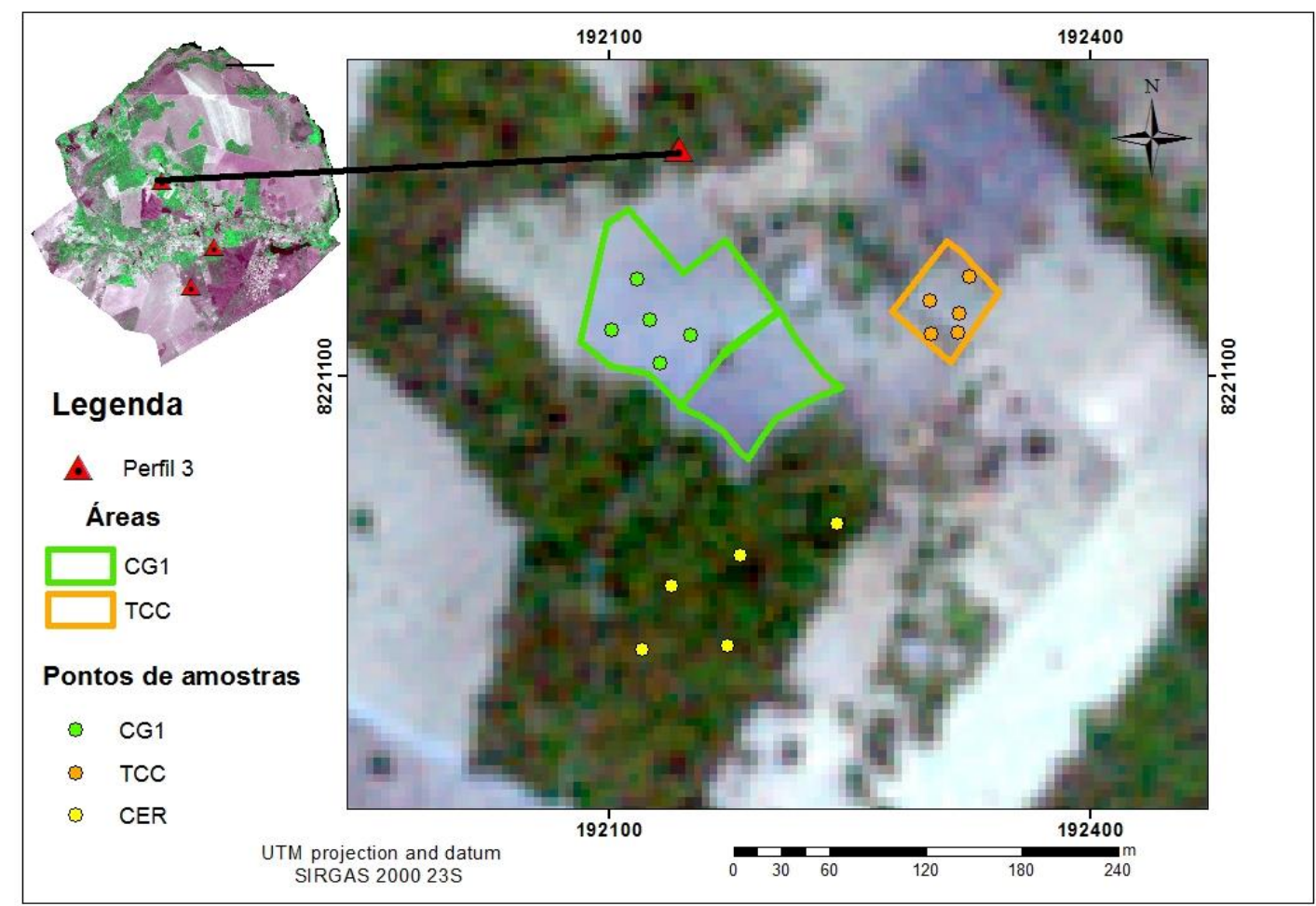

Figura 16. Localização das áreas de diferentes usos do solo e dos pontos de coleta de solos realizados na área de Cerradão, considerando a abertura do Perfil 3 (LVd). Os pontos de amostras foram realizados nos seguintes usos do solo: CG1 (plantio convencional de grãos); TCC (plantio de tangerina com consórcio); CER (Cerradão- área de referencia).

Os demais históricos do uso do solo na área de Cerradão, referente à terceira propriedade foram:

6. Cerrado nativo (CER): remanescente de Cerradão, com formação florestal, utilizado como referência e sem qualquer exploração ou interferência antrópica. Presença de espécies indicadoras de boa fertilidade (p.ex. angico, aroeira, jatobá, ipê-roxo, etc.). Com produção contínua de serapilheira diversificada (folhas, cascas, ramos, troncos, gravetos, flores, inflorescências, frutos, sementes e fragmentos vegetais não identificáveis). 
7. Plantio convencional de grãos (CG1): Área de aproximadamente 1 ha, manejada há 30 anos, com plantio de grãos com práticas convencionais de preparo mínimo do solo. Por cerca de 20 anos, foi utilizada a rotação arroz/feijão/milho, sem realizar adubação e calagem. Nos últimos 10 anos, a área passou a ser gradeada a cada 2 anos e cultivada apenas com milho. Há 5 anos foi realizada calagem na área, sendo utilizado 1 t/ha de calcário dolomítico. O plantio e a adubação do milho são realizados de forma manual. A adubação de plantio é feita próximo à cova com o formulado NPK 4-30-16 (20 g/cova) e na de cobertura é utilizado o nitrato de potássio (20 g/cova). Há muita presença de plantas daninhas, porém não há palhada no solo.

8. Tangerina com consórcio (TCC): area de aproximadamente 0,25 ha, manejada há 5 anos, com plantio de tangerina com preparo conservacionista do solo. Por 21 anos, a área foi cultivada com pastagem Brachiaria decumbens, tendo sido adubada com esterco de gado, sendo a pastagem conduzida com pastejo contínuo de bovinos. Há 4 anos, o pasto foi retirado manualmente e a área foi cultivada com tangerina Ponkan (4 m x $4 \mathrm{~m}$ ). Na área nunca foi realizada a correção de acidez do solo. No local, é realizado consórcio na entrelinha da tangerina, com as seguintes culturas milho/feijão/mandioca. Nos últimos dois anos, foi iniciado o consórcio da tangerina com mandioca. Foi realizada uma adubação inicial na cova com o formulado NPK 430-16 (400 g/cova) e a com esterco de gado (10 litros/cova). Há dois anos, a área recebeu adubação de cobertura com o formulado NPK 10-10-10 (400 g do adubo na circunferência da copa). As plantas daninhas presentes na área são ceifadas quatro vezes/ano, sendo o resíduo enleirado próximo à copa. Na área é preservada a cobertura morta, proveniente de restos de frutos, folhas e plantas daninhas, estando o solo permanentemente coberto. 


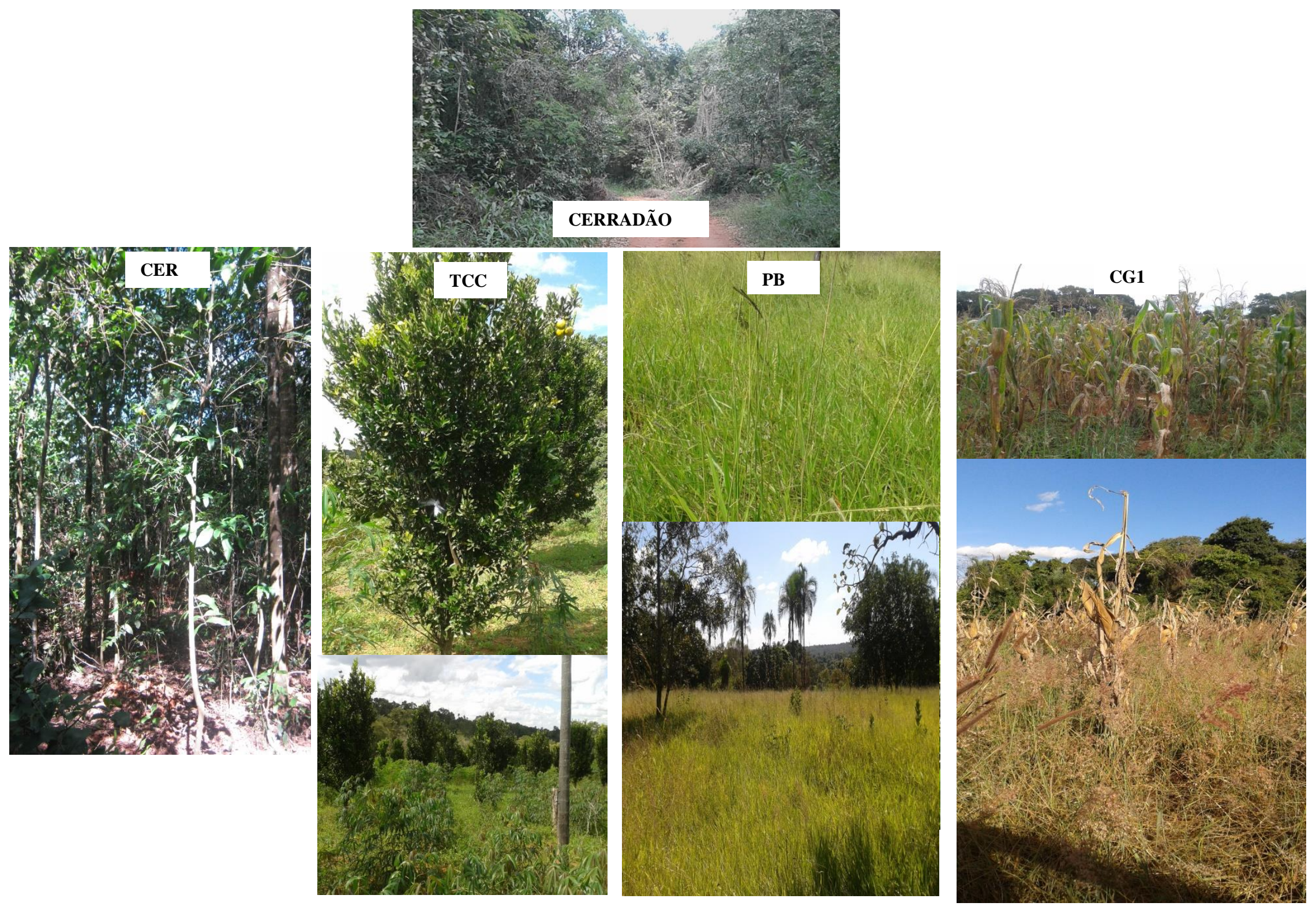

Figura 17. Usos da terra nas áreas sob Cerradão. Onde: CER: Cerradão, TCC: tangerina com consórcio; PB: pastagem debraquiárias; CG1: Plantio convencional de grãos. 
Os solos foram classificados como Latossolo Vermelho Distrófico típico (EMBRAPA, 2013), com textura argilosa, e caracterizados física e quimicamente de acordo com EMBRAPA (2011), cujos valores encontram-se na tabela 11.

Tabela 11. Caracterização física e qúmica de Latossolos Vermelhos distróficos típicos, na profundidade de 0-10 cm, do Quilombo Mesquita - GO, sob diferentes tipos de usos da terra

\begin{tabular}{|c|c|c|c|c|c|c|c|c|c|c|c|}
\hline \multirow[b]{2}{*}{$\begin{array}{r}\text { Usos da } \\
\text { terra }^{(1)}\end{array}$} & \multirow{2}{*}{$\begin{array}{c}\mathrm{pH} \\
\mathrm{em} \\
\mathrm{H}_{2} \mathrm{O}\end{array}$} & $\mathrm{Al}^{+3}$ & $\mathrm{Ca}^{2+}$ & $\mathrm{Mg}^{2+}$ & $\mathrm{H}+\mathrm{Al}$ & $\mathrm{P}$ & $\mathrm{K}$ & \multirow{2}{*}{$\begin{array}{c}\mathrm{m} \\
(\%)\end{array}$} & \multirow[t]{2}{*}{ Silte } & \multirow{2}{*}{$\begin{array}{l}\text { Areia } \\
\mathrm{g} \mathrm{kg}^{-1}\end{array}$} & \multirow[t]{2}{*}{ Argila } \\
\hline & & \multicolumn{4}{|c|}{$\ldots \ldots \ldots\left(\mathrm{cmol}_{\mathrm{c}} \mathrm{dm}^{-3}\right) \ldots \ldots \ldots \ldots \ldots$} & \multicolumn{2}{|c|}{$\left(\mathrm{mg} \mathrm{dm}^{-3}\right)$} & & & & \\
\hline \multicolumn{12}{|c|}{ Cerradão } \\
\hline CER & 5,1 & 0,55 & 4,06 & 1,34 & 9,0 & 1,3 & 148 & 8,7 & 410 & 40 & 550 \\
\hline TCC & 5,8 & 0,06 & 6,34 & 1,95 & 5,7 & 3,7 & 308 & 0,6 & 410 & 40 & 550 \\
\hline $\mathrm{PB}$ & 4,7 & 0,64 & 0,34 & 0,28 & 5,9 & 2,1 & 118 & 41,0 & 280 & 120 & 600 \\
\hline CG1 & 5,9 & 0,03 & 4,57 & 1,28 & 4,1 & 8,4 & 353 & 0,4 & 410 & 40 & 550 \\
\hline \multicolumn{12}{|c|}{ Cerrado sensu stricto } \\
\hline CSS & 4,7 & 0,72 & 0,07 & 0,19 & 6,2 & 0,8 & 54 & 11 & 270 & 100 & 630 \\
\hline TSC & 5,2 & 0,19 & 1,08 & 0,73 & 5,5 & 1,8 & 186 & 2,4 & 270 & 100 & 630 \\
\hline PNB & 4,7 & 0,63 & 0,33 & 0,36 & 7,0 & 0,9 & 76 & 8,0 & 270 & 100 & 630 \\
\hline $\mathrm{CG} 2$ & 5,2 & 0,10 & 1,79 & 1,07 & 5,4 & 7,8 & 79 & 1,2 & 270 & 100 & 630 \\
\hline
\end{tabular}

Os desenhos amostrais, realizados em cada uso do solo estudado, encontram-se nas figuras 13,15 e 16 . As amostras de solos foram coletadas no final do período chuvoso, em abril de 2014. Os pontos de coleta foram estabelecidos ao longo de uma linha imaginária diagonal em cada ambiente de estudo (Figura 18).

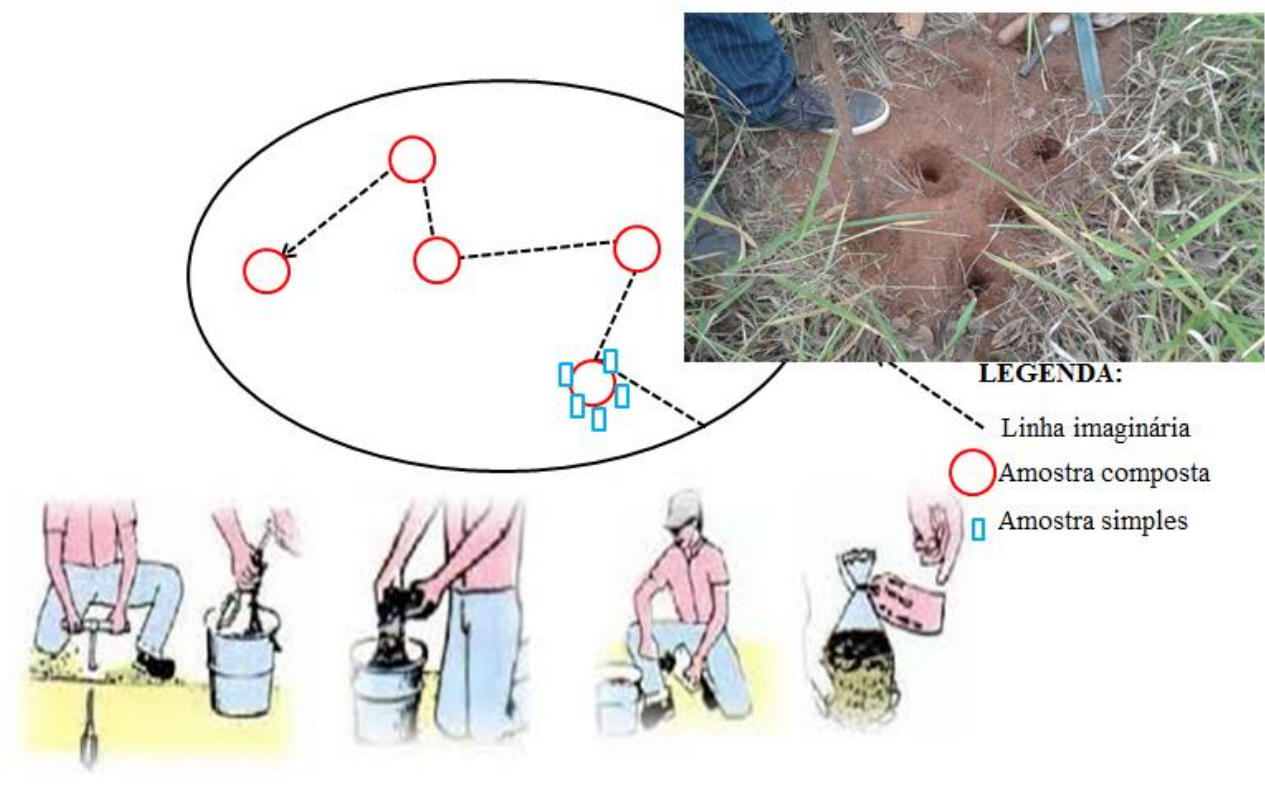

Figura 18. Demonstração da forma da coleta realizada nos solos sob diferentes usos da terra. 
Assim, de acordo com a figura 18, a cada 50 metros foi feita uma coleta de cinco amostras simples de solo, representando uma amostra composta nas profundidades de 0-10 e 10-20 cm. No caso da área sob produção de grãos, a coleta foi realizada na linha e entrelinha da cultura, enquanto que na tangerina, no sentido da projeção da copa das árvores.

Uma parte das amostras foi destorroada, seca ao ar e passada em peneiras de $2 \mathrm{~mm}$ para a realização das análises dos atributos físicos e químicos. Outra parte das amostras foi coletada e colocada em caixa de isopor com gelo e mantidas a $4^{0} \mathrm{C}$ até o momento das análises dos atributos biológicos do solo. Os atributos físicos avaliados foram densidade do solo e densidade de partículas, ambas determinadas pelo método do anel volumétrico, e a porosidade total, obtida pela relação entre a densidade do solo e a densidade de partículas, sendo as análises realizadas segundo EMBRAPA (2011).

Os atributos químicos avaliados foram o $\mathrm{pH}$ do solo e os teores de $\mathrm{P}, \mathrm{K}^{+}$,

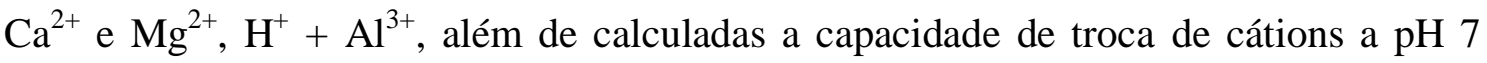
(CTC), a saturação por bases (V) e por alumínio (m). O pH foi determinado em água. O fósforo e o potássio foram extraídos com a solução de Mehlich $1\left(\mathrm{HCl}\right.$ a $0,5 \mathrm{~N}+\mathrm{H}_{2} \mathrm{SO}^{4}$ a $0,025 \mathrm{~N}$ ) e determinados em colorímetro e fotômetro de chama, respectivamente. $\mathrm{O}$ $\mathrm{Ca}^{2+}$ e o $\mathrm{Mg}^{2+}$ foram extraídos em $\mathrm{KCl}$ a $1 \mathrm{~N}$ e determinados por titulação de EDTA. O $\mathrm{H}^{+}+\mathrm{Al}^{3+}$ foi determinado por titulometria, usando-se solução de acetato de cálcio $1 \mathrm{~N} \mathrm{a}$ pH 7 para sua extração. As análises laboratoriais foram realizadas de acordo com EMBRAPA (2011). Foram calculadas ainda as relações Ca:Mg, $(\mathrm{Ca}+\mathrm{Mg}): \mathrm{K}$ e $\mathrm{Mg}: \mathrm{K}$, as quais não passaram por procedimento estatístico.

Foram quantificados o carbono orgânico total do solo (COT) e o $\mathrm{N}$ total do solo e as relações COT/NOT. O COT foi determinado pelo método de Walkley \& Black (EMBRAPA, 2011), e o NOT seguiu a marcha analítica descrita em Bremner (1996). 
Os atributos biológicos avaliados foram carbono e nitrogênio da biomassa microbiana (CBM e NBM, respectivamente), a respiração basal (RB), quocientes microbianos (Qmic C e Qmic N), glomalina facilmente extraível (Glo) e as relações Cmic/Nmic.

O CBM e o NBM foram analisados pelo método da fumigação-extração proposto por Vance et al. (1987). A respiração basal do solo (RB) foi determinada pela quantificação do $\mathrm{CO}_{2}$ liberado durante a incubação do solo em sistema fechado (Jenkinson \& Powlson, 1976). Os quocientes microbianos foram obtidos pela relação entre CBM e COT e NBM e NOT, respectivamente (Anderson \& Domsch, 1993).

Para determinação da proteína reativa facilmente extraível (ou glomalina facilmente extraível) foi utilizado o método de Bradford, seguindo a metodologia de Wright \& Upadhyaya (1996). Pesou-se $1 \mathrm{~g}$ de solo em tubos de falcon, com capacidade para $50 \mathrm{ml}$. Foram feitas replicatas de cada amostra de solo. Adicionou-se $8 \mathrm{ml} \mathrm{de}$ solução tampão de citrato de sódio $20 \mathrm{mM}, \mathrm{pH}$ 7,0, em cada tubo, os quais foram autoclavados por 30 minutos a $121^{\circ} \mathrm{C}$. Em seguida, os frascos foram centrifugados a 5000 rpm por 10 minutos. Para determinação da concentração de glomalina, pipetou-se 50 microlitros do extrato em tubo de ensaio, adicionando-se $1 \mathrm{ml}$ do reagente de Bradford aos tubos. Após esse procedimento, os tubos foram levados para agitação em vortex, aguardando 10 minutos para iniciar leitura de absorbância em espectrofotômetro a $595 \mathrm{~nm}$.

Apesar de se tratar de um estudo observacional, os dados foram analisados como se fosse um delineamento inteiramente casualizado, tendo em vista que os dados atenderam aos pressupostos estatísticos desse tipo delineamento.

Assim, a análise estatística univariada foi realizada utilizando-se o software estatístico SAS versão 9.1 (SAS, 2008) e constituiu de análise de variância (ANOVA) em relação aos dados obtidos em cada uso do solo sob Cerradão ou Cerrado sensu 
stricto, com repetições (5), profundidades $(0-10$ e $10-20 \quad \mathrm{~cm})$ e interação tratamento*profundidade, seguida de teste de média Tukey, ao nível de $5 \%$ de probabilidade, conforme a sensibilidade do método para as médias dos teores dos atributos físicos, químicos e biológicos. Quando a ANOVA não foi considerada significativa em relação à interação tratamento*profundidade, o teste de Tukey foi realizado a partir das médias dos atributos avaliados em cada uma das áreas amostrais.

Para testar a existência de relações significativas entre os atributos, em função dos diferentes manejos, foram utilizadas análises estatísticas multivariadas, utilizando o software CANOCO 4.5 (ter Braac, 1998), desenvolvido pela empresa Microcomputer Power (Ithaca, NY, USA). Para tanto, a fim de verificar o efeito dos atributos físicos e químicos (variáveis explicativas) sobre os atributos biológicos (variáveis respostas) foi utilizada a análise de redundância canônica (RDA), compreendida como um método de ordenação condicionado ou canônico, baseado na distribuição normal, no qual as variáveis explicativas ou ambientais condicionam a resposta das variáveis a serem analisadas.

Dessa forma, os eixos da ordenação condicionada correspondem às direções da maior variabilidade explicada pelas variáveis ambientais (Leps \& Smilauer, 2003). Nesta análise, as variáveis foram transformadas $[\log (x+1)]$ e foi empregado o método de seleção das variáveis ambientais (Forward Selection), o qual permite selecionar e introduzir no modelo somente as variáveis que foram significativas $(P<0,05)$ e que mais contribuíram para a variabilidade dos manejos adotados.

Complementarmente, é fornecida uma estatística, que corresponde a uma medida de qualidade do ajuste e do poder explicativo da RDA. São obtidos uma razão F e um valor P de significância, determinados por meio do teste de permutação de Monte Carlo e um teste F, por meio do aplicativo CANOCO para Windows 4.5 (Leps; Smilauer, 2003). 


\subsection{RESULTADOS E DISCUSSÃO}

\subsubsection{Atributos físicos}

Os valores de densidade do solo e porosidade total nas profundidades de 0 -

10 e $10-20$ cm estão apresentados na tabela 12 , havendo diferenças entre usos da terra e profundidades.

Tabela 12. Densidade do solo (Ds) e porosidade total $(\mathrm{Pt})$ nas áreas manejadas sob Cerradão e Cerrado sensu stricto.

\begin{tabular}{|c|c|c|c|c|c|c|}
\hline \multirow[t]{2}{*}{ Atributos físicos } & \multirow{2}{*}{$\begin{array}{l}\text { Profundidade } \\
\text { (cm) }\end{array}$} & \multicolumn{4}{|c|}{ Usos da terra* } & \multirow[b]{2}{*}{ Média } \\
\hline & & CER & TCC & CG1 & PB & \\
\hline \multirow{2}{*}{ Ds $\left(\mathrm{Mg} \mathrm{dm}^{-3}\right)$} & $0-10$ & $0,82 \mathrm{cB}$ & $0,94 \mathrm{bA}$ & $0,92 \mathrm{bcB}$ & $1,06 \mathrm{aA}$ & \\
\hline & $10-20$ & $0,97 \mathrm{bA}$ & $0,87 \mathrm{cA}$ & $1,09 \mathrm{aA}$ & $1,03 \mathrm{abA}$ & \\
\hline \multirow{2}{*}{$\mathrm{Pt}(\%)$} & $0-10$ & 69,89 & 66,36 & 70,07 & 62,80 & $67,28 \mathrm{~A}$ \\
\hline & $10-20$ & 70,05 & 66,94 & 69,70 & 62,50 & $67,30 \mathrm{~A}$ \\
\hline \multirow[t]{2}{*}{ Média } & & $69,97 \mathrm{a}$ & $66,62 \mathrm{~b}$ & $69,88 \mathrm{a}$ & $62,65 \mathrm{c}$ & \\
\hline & & CSS & TSC & CG2 & PNB & \\
\hline \multirow{2}{*}{ Ds $\left(\mathrm{Mg} \mathrm{dm}^{-3}\right)$} & $0-10$ & 0,95 & 0,95 & 1,04 & 0,96 & $0,97 \mathrm{~A}$ \\
\hline & $10-20$ & 0,92 & 1,01 & 1,07 & 0,94 & $0,98 \mathrm{~A}$ \\
\hline Média & & $0,93 \mathrm{c}$ & $0,98 \mathrm{~b}$ & $1,05 \mathrm{a}$ & $0,95 \mathrm{bc}$ & \\
\hline \multirow{2}{*}{$\mathrm{Pt}(\%)$} & $0-10$ & $66,53 \mathrm{aA}$ & $66,50 \mathrm{aA}$ & $62,36 \mathrm{bA}$ & $65,98 \mathrm{aA}$ & \\
\hline & $10-20$ & $66,75 \mathrm{abA}$ & $67,79 \mathrm{aA}$ & $62,60 \mathrm{cA}$ & $64,01 \mathrm{bcA}$ & \\
\hline
\end{tabular}

A densidade do solo (Ds) variou de 0,82 a $1,06 \mathrm{Mg} \mathrm{dm}^{-3}$ e de 0,87 a 1,09 $\mathrm{Mg} \mathrm{dm}^{-3}$ nas profundidades de 0-10 e 10-20 cm, respectivamente, nos solos manejados sob Cerradão, havendo diferença significativa entre a interação profundidade e manejo o que não foi observado na área de cerrado (Tabela 12). No Cerradão, a menor densidade foi encontrada no CER (área nativa), enquanto que o maior valor foi na pastagem (PB), enquanto que os demais usos apresentaram valores semelhantes e intermediários. Apenas nos usos CER e CG1, a Ds foi menor na profundidade de 0-10 cm, quando comparado com a de $10-20 \mathrm{~cm}$, nos demais usos, não houve diferença entre as profundidades.

Nas áreas sob Cerrado sensu stricto, verifica-se que a Ds variou de 0,93 a 1,05 $\mathrm{Mg} \mathrm{dm}^{-3}$, sendo o menor valor no CSS, o maior no CG2 (plantio convencional de 
grãos), com valor intermediário no TSC (tangerina sem consórcio), sendo o valor da Ds da PNB semelhante ao TSC e CSS.

Os valores observados encontram-se semelhantes às densidades relatadas por Camargo \& Alleoni (1997) e Lal (1999), que consideram que o solo de textura argilosa, com Ds inferior a $1,2 \mathrm{Mg} \mathrm{dm}^{-3}$, não apresenta limitação ao sistema radicular, e por Dexter (2004), que cita valores médios de densidade para solos argilosos de 1,0-1,2 $\mathrm{g} \mathrm{cm}^{-3}$. Os baixos valores de Ds encontrados nos usos das terras estudados resultam provavelmente do reduzido tráfego de maquinário nas operações agrícolas de implantação, tratos culturais e colheitas, já que os quilombolas, por ausência de tecnologias adequadas, realizam essas operações praticamente de forma manual.

No entanto, para Goedert (2005), a Ds encontra-se dentro do padrão de sustentabilidade para este atributo em Latossolos tropicais de textura argilosa, quando o seu valor é inferior a $1,0 \mathrm{Mg} \mathrm{dm}^{-3}$, em solos de uso agrícola.

Observa-se que nas áreas sob Cerradão, apenas o PB apresentou Ds maior que 1. Na profundidade de 10-20, o menor valor foi no TCC, enquanto que o CG1 e PB apresentaram valores maiores e significativamente semelhantes, com Ds acima de 1. Nas áreas sob Cerrado sensu stricto, o uso CG2 apresentou Ds maior que 1 nas duas profundidades, enquanto que no TSC a Ds foi maior que 1 apenas na profundidade de 10-20 cm. De maneira geral, os menores teores de Ds foram nas áreas nativas, Carneiro et al. (2009) e Wendling et al. (2012) também observaram menor Ds em áreas nativas em relação aos solos cultivados, indicando melhor qualidade física dessas áreas.

Utilizando-se as áreas nativas como referência, pode-se verificar que a Ds foi influenciada pela mudança de uso do solo, já que os manejos PB, TCC e CG1 aumentaram a Ds, em comparação com CER, com destaque para o PB que apresentou o maior valor de Ds (1,06 $\left.\mathrm{Mg} \mathrm{dm}^{-3}\right)$. Os manejos CG2 (plantio convencional de grãos) e TSC (tangerina sem consórcio), comparados com o CSS (Cerrado sensu stricto), 
também aumentaram o valor da Ds. Na profundidade de 10-20 cm, os menores valores de Ds foram encontrados na tangerina com consórcio (TCC) e nas áreas nativas (CER, CSS e PNB), enquanto que nos usos da terra, pautados em manejos convencionais, tiveram Ds acima do valor proposto por Goedert (2005). Os resultados corroboram os dados encontrados por Silva et al. (2014) e Costa et al. (2015) nos quais verificaram que em solos manejados sob sistema convencional a Ds foi superior aos valores do plantio direto.

Como a Ds possui estreita relação com outros atributos físicos do solo, o aumento da mesma está associado à diminuição da porosidade total, macroporosidade, condutividade hidráulica e absorção iônica, assim como ao consequente aumento da microporosidade e da resistência mecânica à penetração (Melo Filho et al. 2006, Mendes et al. 2006). Estas alterações na qualidade física do solo desencadeiam, no geral, a diminuição da produtividade agrícola (Foloni et al. 2003, Secco et al. 2005, Santos et al. 2006)

Quanto à porosidade total (Pt), a mesma variou de 62,80 a 70,07\% e de 62,50 a 70,05\% nas profundidades de 0-10 e 10-20 cm, respectivamente, nas áreas manejadas sob Cerradão. Nas áreas sob Cerrado sensu stricto, a Pt variou de 62,36 a $66,53 \%$ e de 62,60 a $67,79 \%$ nas profundidades de $0-10$ e $10-20 \mathrm{~cm}$, respectivamente (Tabela 12). Em ambas fitofisionomias, a Pt foi semelhante entre as profundidades, conforme observado por Pignataro Netto et al. (2009), Wendling et al. (2012) e Guimarães et al. (2016).

Observa-se que, com exceção do CG1 e TSC, os manejos convencionais tiveram Pt menor que as áreas nativas (PNB, CSS e CER) e conservacionistas (TCC), sendo o PB o manejo com o menor valor de Pt. Para os autores acima, os valores mais baixos de densidade em seus estudos referem-se à área de pastagem na região do Cerrado, possivelmente devido à decomposição das raízes dos vegetais, além desse 
manejo favorecer a exposição do solo a processos degradativos devido aos problemas de compactação.

\subsubsection{Atributos químicos}

$\mathrm{Na}$ área sob Cerradão, só houve interação significativa entre os usos da terra e profundidades para os atributos $\mathrm{Ca}, \mathrm{P}$ e V (Tabela 13). Os demais atributos $\mathrm{pH}, \mathrm{Al}$, H+Al, m, K, Mg, SB e CTC não apresentaram interação significativa (Figuras 19 e 21). Nas áreas sob Cerrado sensu stricto, não houve interação significativa na acidez potencial (Figura 20), porém os demais atributos apresentaram interação significativa (Tabelas 13, 14, 15, 16 e 17).

Tabela 13. Teores de cálcio $(\mathrm{Ca})$, fósforo $(\mathrm{P})$ e a saturação por bases $(\mathrm{V})$ nas áreas manejadas sob Cerradão

\begin{tabular}{cccccc}
\hline Atributos químicos & $\begin{array}{c}\text { Profundidade } \\
(\mathbf{c m})\end{array}$ & CER & TCC & CG1 & PB \\
\cline { 2 - 5 } & $0-10$ & $1,61 \mathrm{bA}$ & $6,45 \mathrm{aA}$ & $4,83 \mathrm{aA}$ & $0,34 \mathrm{bA}$ \\
$\mathrm{Ca}\left(\mathrm{cmolc} \mathrm{dm}^{-3}\right)$ & $10-20$ & $0,75 \mathrm{cA}$ & $6,68 \mathrm{aA}$ & $3,78 \mathrm{bB}$ & $0,21 \mathrm{cA}$ \\
& $0-10$ & $1,34 \mathrm{bA}$ & $2,36 \mathrm{aA}$ & $1,42 \mathrm{bA}$ & $1,31 \mathrm{bA}$ \\
& $10-20$ & $0,83 \mathrm{bB}$ & $1,62 \mathrm{bA}$ & $3,49 \mathrm{aB}$ & $1,02 \mathrm{bA}$ \\
$\mathrm{P}\left(\mathrm{mg} \mathrm{dm}^{-3}\right)$ & $0-10$ & $23,57 \mathrm{bA}$ & $60,82 \mathrm{aA}$ & $63,48 \mathrm{aA}$ & $13,40 \mathrm{bA}$ \\
& $10-20$ & $15,10 \mathrm{Ba}$ & $62,54 \mathrm{aA}$ & $58,82 \mathrm{aA}$ & $10,61 \mathrm{bA}$ \\
\hline & & &
\end{tabular}

De maneira geral, o Ca, P e V diminuíram em profundidade (Tabela 13). As áreas que receberam adubo e correção (TCC e CG1) foram as que apresentaram os maiores valores desses atributos estudados. Já o PB apresentou o menor valor, enquanto o CER apresentou valor intermediário. No Cerrado sensu stricto (Tabela 14), esses atributos químicos, em geral, também foram maiores nas áreas que receberam adubos e corretivos (TSC e CG2), e, menores nos demais manejos.

Assim, os valores de $\mathrm{Ca}$, nas áreas sob Cerradão, foram maiores nos usos TCC e CG1, havendo diferença desses valores em profundidade, apenas no CG1. O PB apresentou o menor valor, enquanto que o CER apresentou valor intermediário (Tabela 
13). Nas áreas sob Cerrado sensu stricto, o Ca também foi maior no TSC e CG2, ficando as áreas nativas (CSS e PNB), com valores menores. De acordo com Souza \& Lobato (2004), para solos do Cerrado, valores de Ca menores $1,5 \mathrm{cmol}_{\mathrm{c}} \mathrm{dm}^{-3}$ são considerados baixos, e entre 1,5 e 7,0 $\mathrm{cmol}_{\mathrm{c}} \mathrm{dm}^{-3}$ são considerados adequados. Verificase, assim, que apenas o PB apresentou valor de Ca baixo $\left(0,34 \mathrm{cmol}_{\mathrm{c}} \mathrm{dm}^{-3}\right)$. No Cerrado sensu stricto, os valores de Ca foram considerados adequados apenas no manejo CG2 $\left(1,79 \mathrm{cmol}_{\mathrm{c}} \mathrm{dm}^{-3}\right)$, na profundidade de $0-10 \mathrm{~cm}$, sendo esses valores baixos nos demais manejos (Tabela 14).

Tabela 14. Teores de cálcio $(\mathrm{Ca})$, fósforo $(\mathrm{P})$ e saturação por bases $(\mathrm{V})$ nas áreas manejadas sob Cerrado sensu stricto

\begin{tabular}{cccccc}
\hline Atributos químicos & $\begin{array}{c}\text { Profundidade } \\
(\mathbf{c m})\end{array}$ & CSS & TSC & CG2 & PNB \\
\cline { 3 - 6 } & $0-10$ & $0,07 \mathrm{cA}$ & $1,08 \mathrm{bB}$ & $1,79 \mathrm{aA}$ & $0,33 \mathrm{cA}$ \\
$\mathrm{Ca}\left(\mathrm{cmol}_{\mathrm{c}} \mathrm{dm}^{-3}\right)$ & $10-20$ & $0,11 \mathrm{cA}$ & $1,54 \mathrm{aA}$ & $1,09 \mathrm{bB}$ & $0,26 \mathrm{cA}$ \\
& & & & & \\
& $0-10$ & $0,76 \mathrm{bA}$ & $1,76 \mathrm{bA}$ & $7,78 \mathrm{aA}$ & $0,86 \mathrm{bA}$ \\
$\mathrm{P}\left(\mathrm{mg} \mathrm{dm}^{-3}\right)$ & $10-20$ & $0,68 \mathrm{bA}$ & $1,56 \mathrm{aA}$ & $0,65 \mathrm{bB}$ & $1,96 \mathrm{aB}$ \\
& & & & & \\
& $0-10$ & $5,99 \mathrm{cA}$ & $29,05 \mathrm{bA}$ & $36,33 \mathrm{aA}$ & $11,24 \mathrm{cA}$ \\
$\mathrm{V}(\%)$ & $10-20$ & $6,32 \mathrm{bA}$ & $36,91 \mathrm{aA}$ & $27,00 \mathrm{aA}$ & $9,86 \mathrm{bA}$ \\
& & & & &
\end{tabular}

*CSS: Cerrado sensu stricto; TSC: tangerina sem consórcio; PNB: pastagem de plantas nativas e braquiárias; CG2: plantio convencional de grãos. Médias seguidas de mesma letra minúscula comparam os usos em uma mesma profundidade e maiúscula comparam os usos dentro de cada profundidade (Tukey; $\mathrm{p}<0,05$ )

Com relação ao P, verifica-se que nas áreas sob Cerradão (Tabela 13), na profundidade de 0-10, o maior valor foi no TCC, e, os menores valores ocorreram nos demais manejos. Na profundidade de $10-20 \mathrm{~cm}$, o maior valor de P foi no uso CG1. No Cerrado sensu stricto, o maior valor de $\mathrm{P}$ foi no uso $\mathrm{CG} 2$, e, os demais valores apresentaram os menores valores (Tabela 14). Segundo Sousa et al. (2002), considerados os teores de argila dos solos estudados, os valores de $\mathrm{P}$ foram considerados muito baixos nos manejos CSS, PNB, TSC, CER, PB e TCC. Para os manejos CG1 e CG2, os valores de P foram considerados altos. 
Com relação à saturação de bases (V), nas áreas sob Cerradão, os maiores ocorreram em TCC e CG1 e, o menor, foi em PB (Tabela 13). Nas áreas sob Cerrado sensu stricto, os maiores valores foram em TSC e CG2, e o menor, foi em CSS (Tabela 14). De acordo Goedert (2005), apenas o CG1 e TCC estão com valores de saturação de bases dentro do nível de sustentabilidade, ou seja, maior que $40 \%$.

Os valores de $\mathrm{pH}$, alumínio, saturação por alumínio (m) e acidez potencial $(\mathrm{H}+\mathrm{Al})$ estão apresentados nas figuras 19 e 20 e tabela 15 . Com relação ao parâmetro $\mathrm{pH}$, nas áreas sob Cerradão, verifica-se que o maior valor de $\mathrm{pH}$ foram nas áreas corrigidas (TCC e CG1), que apresentaram os maiores valores de $\mathrm{pH}$ em torno de 6, evidenciando baixa acidez dos solos manejados. O PB apresentou o menor valor de $\mathrm{pH}$ $(4,7)$, demostrando alta acidez, e o CER apresentou acidez média, com pH em torno de 5,2. Ademais, não houve diferença de pH em relação a profundidade (Figura 19A).
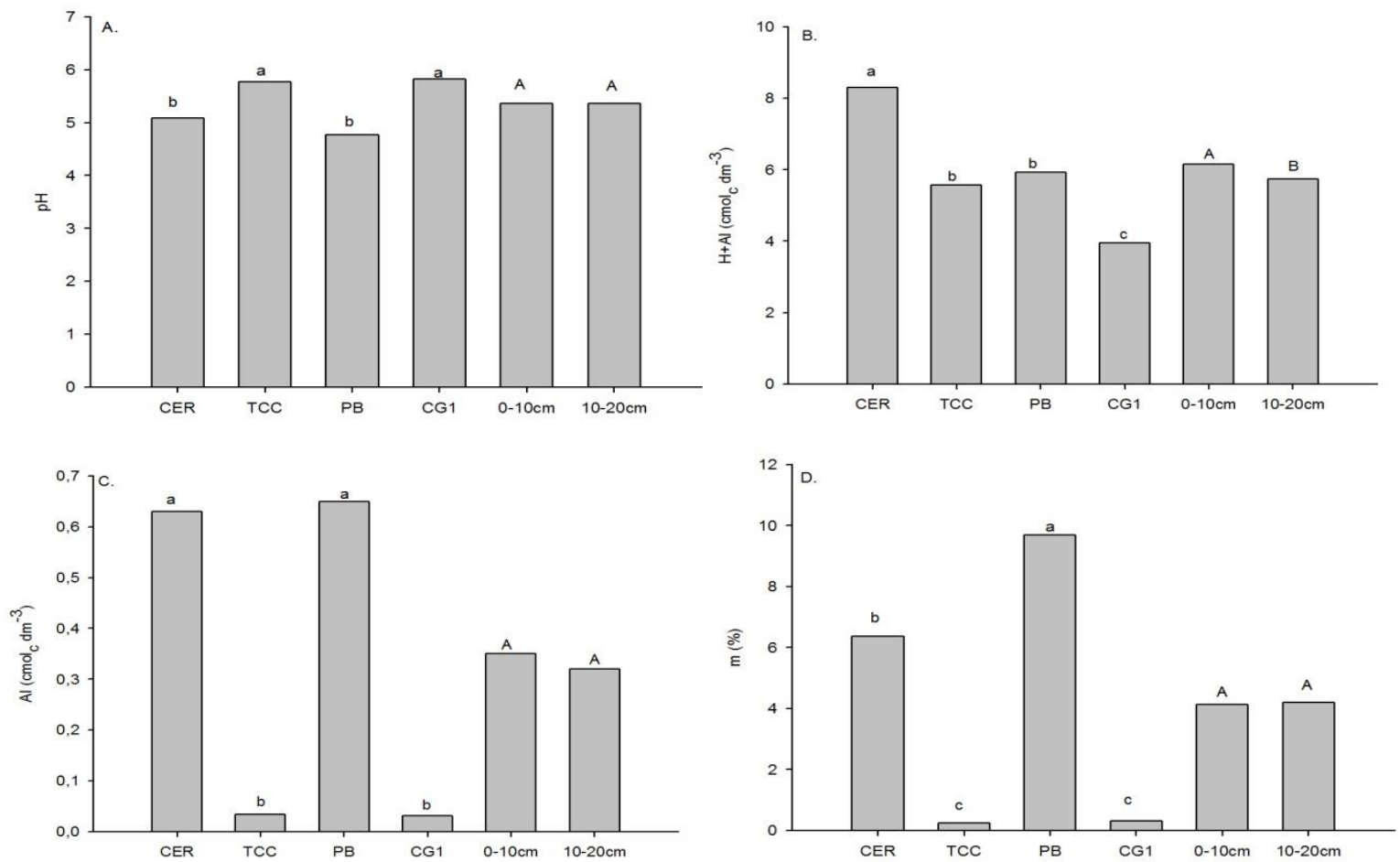

Figura 19. Teores de $\mathrm{pH}$, acidez potencial $(\mathrm{H}+\mathrm{Al})$, alumínio $(\mathrm{Al})$ e saturação por alumínio (m) nas profundidades de 0-10 e 10-20 cm. Nos manejos: CER: cerradão; TCC: tangerina com consórcio; PB: pastagem de braquiárias e CG1: plantio convencional de grãos. Médias seguidas de mesma letra minúscula comparam os usos em uma mesma profundidade e maiúscula comparam os usos dentro de cada profundidade (Tukey; $\mathrm{p}<0,05$ ). 
Com relação ao $\mathrm{pH}$, na área sob Cerrado sensu stricto, os valores de $\mathrm{pH}$, variaram de 4,69 a 5,16 (Tabela 15), onde apenas o TSC apresentou o maior valor de pH, com acidez considerada média. Os demais usos da terra apresentaram acidez baixa.

Tabela 15. Teores de $\mathrm{pH}$, alumínio (Al) e saturação por alumínio (m) nas áreas manejadas sob Cerrado sensu stricto.

\begin{tabular}{|c|c|c|c|c|c|}
\hline \multirow{2}{*}{$\begin{array}{l}\text { Atributos } \\
\text { químicos }\end{array}$} & \multirow{2}{*}{$\begin{array}{l}\text { Profundidade } \\
\text { (cm) }\end{array}$} & \multicolumn{4}{|c|}{ Usos da terra* } \\
\hline & & CSS & TSC & CG2 & PNB \\
\hline \multirow{2}{*}{$\mathrm{pH}$} & $0-10$ & $4,74 \mathrm{bcA}$ & $5,16 \mathrm{abA}$ & $4,70 \mathrm{aA}$ & $4,69 \mathrm{cAB}$ \\
\hline & $10-20$ & $4,77 \mathrm{bA}$ & $5,17 \mathrm{aA}$ & $5,00 \mathrm{abA}$ & $4,83 \mathrm{bB}$ \\
\hline \multirow{2}{*}{$\mathrm{Al}\left(\mathrm{cmol}_{\mathrm{c}} \mathrm{dm}^{-3}\right)$} & $0-10$ & $0,71 \mathrm{aA}$ & $0,19 \mathrm{bA}$ & $0,10 \mathrm{bA}$ & $0,62 \mathrm{aA}$ \\
\hline & $10-20$ & $0,62 \mathrm{aA}$ & $0,10 \mathrm{bA}$ & $0,16 \mathrm{bA}$ & $0,51 \mathrm{aA}$ \\
\hline \multirow[t]{2}{*}{$\mathrm{m}(\%)$} & $0-10$ & $10,95 \mathrm{aA}$ & $2,41 \mathrm{cA}$ & $1,21 \mathrm{cA}$ & 7,97 bA \\
\hline & $10-20$ & $9,54 \mathrm{aA}$ & $1,33 \mathrm{cA}$ & $2,32 \mathrm{cA}$ & $7,19 \mathrm{bA}$ \\
\hline
\end{tabular}

Quanto à acidez potencial $(\mathrm{H}+\mathrm{Al})$, não houve diferenças os usos da terra em ambas as fisionomias estudadas (Figuras 19B e 20). Nas áreas sob Cerradão, os maiores valores de acidez potencial foi no CER, e, os menores foram no TCC e PB, com o maior valor na profundidade de 0-10 cm (Figura 19). O maior valor de $\mathrm{H}+\mathrm{Al}$ foi maior na área nativa, devido à influência da matéria orgânica do solo, que gera mais $\mathrm{H}$ no complexo sortivo.

Nas áreas sob Cerrado sensu stricto, os maiores valores de acidez potencial foi no na pastagem nativa com braquiárias (PNB), que apresentou valor de $\mathrm{H}+\mathrm{Al}$ semelhante ao cerrado sensu stricto (CSS). Os usos da terra CG2 (plantio convencional de grãos) e o TSC (tangerina sem consórcio) apresentaram os menores valores de $\mathrm{H}+\mathrm{Al}$. Assim, como nas áreas manejadas sob Cerradão, os valores de $\mathrm{H}+\mathrm{Al}$ foram maiores na profundidade de 0-10 $\mathrm{cm}$ (Figura 20). 


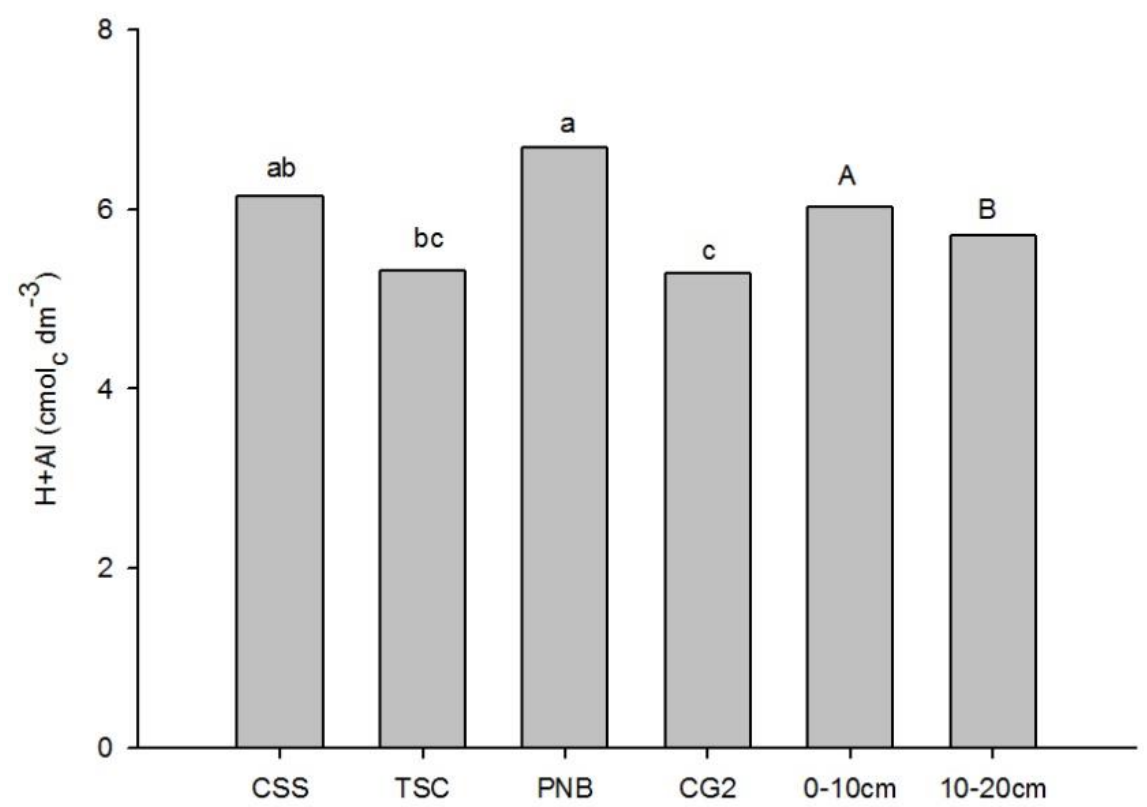

Figura 20. Teores de acidez potencial $(\mathrm{H}+\mathrm{Al})$ nas profundidades de $0-10$ e $10-20 \mathrm{~cm}$. Nos manejos: CSS: cerrado sensu stricto; TSC: tangerina sem consórcio; PNB: pastagem de plantas nativas e braquiárias e CG2: plantio convencional de grãos. Médias seguidas de mesma letra minúscula comparam os usos em uma mesma profundidade e maiúscula comparam os usos dentro de cada profundidade (Tukey; $\mathrm{p}<0,05$ ).

Nas áreas sob Cerradão, o alumínio (Al), como esperado, teve comportamento contrário ao $\mathrm{pH}$, ou seja, os menores valores foram encontradas nas áreas de $\mathrm{pH}$ mais altos (CG1 e $\mathrm{TCC}$ ) e os maiores teores de $\mathrm{Al}$ foram nos manejos com pH mais baixo (CER e PB) (Figura 19A e 19C). Nas áreas sob Cerrado sensu stricto, os menores valores foram encontradas nas áreas de $\mathrm{pH}$ mais altos (CG2 e TSC) e os maiores teores de $\mathrm{Al}$ foram nos manejos com $\mathrm{pH}$ mais baixo (CSS e PNB) (Tabela 15). Os valores de saturação por alumínio (m) apresentaram comportamente semelhantes ao Al (Figura 19D e Tabela 15)

Os valores de CTC variaram de 5,67 a $15,94 \mathrm{cmol}_{c} \mathrm{dm}^{-3}$ e de 5,29 a 16,95 $\mathrm{cmol}_{\mathrm{c}} \mathrm{dm}^{-3}$, para as profundidades de 0-10 e 10-20 cm, respectivamente nos usos da terra sob Cerradão (Figura 21D). Assim, o maior valor de CTC foi na tangerina com consórcio (TCC), enquanto que os usos CER e CG1 apresentaram valores 
intermediários, enquanto que o PB teve o menor valor de CTC (Figura 21D). Já nas áreas sob Cerrado sensu stricto, o menor valor de CTC foi no CSS e, os demais usos, apresentaram os maiores valores (Tabela 16).

Tabela 16. Teores de soma de bases (SB) e capacidade de troca catiônica (CTC) nas áreas manejadas sob Cerrado sensu stricto.

\begin{tabular}{|c|c|c|c|c|c|}
\hline \multirow[t]{2}{*}{ Atributos químicos } & \multirow{2}{*}{$\begin{array}{l}\text { Profundidade } \\
(\mathrm{cm})\end{array}$} & \multicolumn{4}{|c|}{ Manejos* } \\
\hline & & CSS & TSC & CG2 & PNB \\
\hline \multirow[t]{2}{*}{$\mathrm{SB}\left(\mathrm{cmol}_{\mathrm{c}} \mathrm{dm}^{-3}\right)$} & $0-10$ & $0,39 \mathrm{cA}$ & $2,28 \mathrm{bA}$ & $3,06 \mathrm{aA}$ & $0,89 \mathrm{cA}$ \\
\hline & $10-20$ & $0,42 \mathrm{cA}$ & $3,04 \mathrm{aA}$ & $1,90 \mathrm{bB}$ & $0,70 \mathrm{cA}$ \\
\hline \multirow[t]{2}{*}{$\mathrm{CTC}\left(\mathrm{cmol}_{\mathrm{c}} \mathrm{dm}^{-3}\right)$} & $0-10$ & $6,59 \mathrm{bA}$ & $7,82 \mathrm{aA}$ & $8,44 \mathrm{aA}$ & $7,84 \mathrm{aA}$ \\
\hline & $10-20$ & $6,51 \mathrm{bA}$ & $8,14 \mathrm{aA}$ & 7,09abB & 7,13abA \\
\hline
\end{tabular}

Para Goedert (2005) e Papa et al. (2011), conforme os padrões estabelecidos para a CTC em Latossolos tropicais de textura argilosa, valores desse atributo menores que $10,00 \mathrm{cmol}_{\mathrm{c}} \mathrm{dm}^{-3}$, não são considerados sustentáveis, do ponto de vista dos indicadores de qualidade. Observa-se na Figura 21D, na profundidade de 0-10 cm, que os usos CG1, CER e TCC apresentaram valores de CTC acima ao padrão estabelecido, enquanto que PB apresentou CTC com valor menor do que a estabelecida. Na profundidade de 10-20 cm, apenas o manejo TCC teve CTC maior que o limite estabelecido como crítico. Nas áreas sob vegetação nativa (cerradão - CER) e com consórcio (TCC) o valor da CTC está relacionada com o maior teor da MOS, enquanto que no manejo convencional (CG1), a maior CTC pode estar relacionada ao efeito da calagem. Nas áreas sob Cerrado sensu stricto, a menor CTC foi no CSS nas duas profundidades, já, os demais usos tiveram comportamento semelhantes, apresentando os maiores valores (Tabela 16). Todavia, em todos os usos, os valores de CTC estão abaixo do nível de sustentabilidade, estipulado por Goedert (2005).

De manaeira geral, os menores valores de CTC revelam que os solos tropicais, intensamente intemperizados apresentam, como uma das suas principais 
características químicas, a baixa CTC, sendo a matéria orgânica do solo responsável por 75 a $85 \%$ da CTC desses solos (Siqueira Neto et al., 2009), haja vista tratar-se de Latossolos muito evoluídos, nos quais a mineralogia predominante é constituída por sesquióxidos de Fe e Al e caulinita (Barbosa \& Lacerda, 2009, Campos et al., 2010), que exercem pouca influência sobre a CTC.

Quanto à soma de bases (SB), nas áreas sob Cerrado sensu stricto, os maiores valores foram em TSC e CG2, e, as áreas nativas apresentaram os menores valores (Tabela 16). Nas áreas sob Cerradão, na figura 21C, a SB teve o mesmo comportamento que as áreas sob Cerrado.
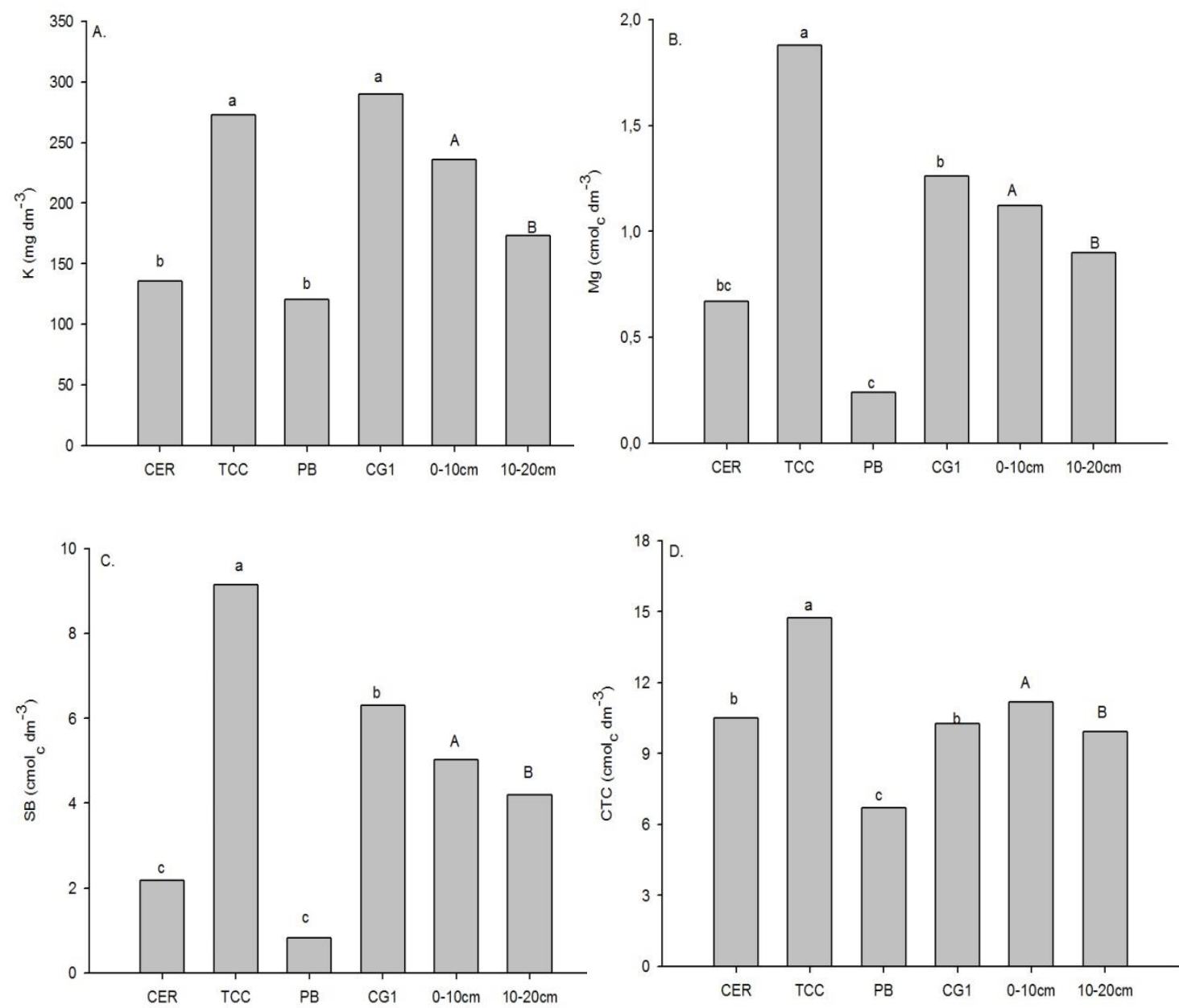

Figura 21. Teores de $\mathrm{K}$ (potássio), Mg (magnésio), SB (soma de bases) e CTC (capacidade de troca catiônica) nas profundidades de 0-10 e 10-20 cm. Nos manejos: CER: cerradão; TCC: tangerina com consórcio; PB: pastagem de braquiárias e CG1: plantio convencional de grãos. Médias seguidas de mesma letra minúscula comparam os usos em uma mesma profundidade e maiúscula comparam os usos dentro de cada profundidade (Tukey; $\mathrm{p}<0,05$ ). 
Os valores de $\mathrm{K}$ e $\mathrm{Mg}$ estão na figura $21 \mathrm{~A}$ e $21 \mathrm{~B}$ e tabela 17 , sendo essas variáveis maiores nas áreas adubadas, em ambas as fisionomias. Nas áreas sob Cerradão, verifica-se que os valores de $\mathrm{K}$ variaram de 130 a $300 \mathrm{mg} \mathrm{dm}{ }^{-3}$, sendo esse valor maior na profunidade de $0-10$. Os maiores valores foram em TCC e CG1 e, os menores em CER e PB (Figura 21A). Nas áreas sob Cerrado sensu stricto, os valores de $\mathrm{K}$ variaram de 53,40 a 205, $67 \mathrm{mg} \mathrm{dm}^{-3}$, sendo o maior valor no uso TSC (Tabela 17), com valor maior de $100 \mathrm{mg} \mathrm{dm}^{-3}$. Esses valores elevados podem ser devido ao material de origem (rochas pelíticas) que são ricas em $\mathrm{K}$, bem como pelo uso excessivo de fontes de potássio (NPK e nitrato de potássio).

Com relação ao $\mathrm{Mg}$, verifica-se nas áreas sob Cerradão, que os maiores valores foram nos usos TCC e CG1, o uso PB apresentou o menor valor, enquanto o CER apresntou vaor intermediário (Figura 21B). Na área sob Cerrado sensu stricto, o Mg se comportou da mesma forma que no Cerradão, sendo maior nas áreas que foram adubadas (Tabela 17). Segundo, Souza \& Lobato (2004), valores adequados de Mg variam entre 0,5 a 2,0 $\mathrm{cmol}_{\mathrm{c}} \mathrm{dm}^{-3}$, assim, os usos da terra que apresentaram valores de Mg baixo foram o PB e, as áreas nativas (CSS e PNB) sob Cerrado sensu stricto.

Tabela 17. Teores de Mg (magnésio) e potássio (K) nas áreas manejadas sob Cerrado sensu stricto.

\begin{tabular}{cccccc}
\hline Atributos químicos & $\begin{array}{c}\text { Profundidade } \\
(\mathbf{c m})\end{array}$ & $\mathbf{C S S}$ & TSC & CG2 & PNB \\
\cline { 3 - 5 } & $0-10$ & $0,19 \mathrm{cA}$ & $0,73 \mathrm{bA}$ & $1,07 \mathrm{aA}$ & $0,36 \mathrm{cA}$ \\
$\mathrm{Mg}\left(\mathrm{cmol}_{\mathrm{c}} \mathrm{dm}^{-3}\right)$ & $10-20$ & $0,17 \mathrm{bA}$ & $0,98 \mathrm{aA}$ & $0,67 \mathrm{abB}$ & $0,29 \mathrm{bA}$ \\
& & & & & \\
& $0-10$ & $54,75 \mathrm{bA}$ & $185,5 \mathrm{aA}$ & $76,25 \mathrm{bA}$ & $79,25 \mathrm{bA}$ \\
$\mathrm{K}\left(\mathrm{mg} \mathrm{dm}^{-3}\right)$ & $10-20$ & $53,40 \mathrm{bA}$ & $205,67 \mathrm{aA}$ & $55,50 \mathrm{bB}$ & $59,00 \mathrm{bB}$
\end{tabular}

*CSS: Cerrado sensu stricto; TSC: tangerina sem consórcio; PNB: pastagem de plantas nativas e braquiárias; CG2: plantio convencional de grãos. Médias seguidas de mesma letra minúscula comparam os usos em uma mesma profundidade e maiúscula comparam os usos dentro de cada profundidade (Tukey; $\mathrm{p}<0,05$ ).

Merece destaque os valores muitos altos nas camadas superficiais (acima de $100 \mathrm{mg} \mathrm{dm}^{-3}$ ), que também foi verificado por Santi et al. (2012). Para Shiratsuchi et al. (2007), Nogara Neto et al. ( 2011) e Escosteguy (2012), solos com altos teores de K 
(acima de $100 \mathrm{mg} \mathrm{dm}^{-3}$ ), concentrados nas camadas superficiais $(0-0,05$ ou $0-0,10 \mathrm{~m})$, e a questão do desbalanço entre as relações $\mathrm{Ca}: \mathrm{Mg}, \mathrm{Mg}: \mathrm{K}, \mathrm{Ca}+\mathrm{Mg} / \mathrm{K}$ e devem ser melhor estudados e compreendidos, pois um desequilíbrio nessas relações pode afetar a produtividade das culturas.

Na tabela 18 são apresentadas as relações de $\mathrm{Ca}: \mathrm{Mg}, \mathrm{Mg}: \mathrm{K}$ e $(\mathrm{Ca}+\mathrm{Mg}): \mathrm{K}$. Quanto ao Ca:Mg, verifica-se, verifica-se que apenas os usos TCC e CG1 (nas áreas sob Cerradão), apresentaram essa relação adequada, ou seja, variando entre 3-5, de acordo com Souza \& Lobato (2004). Os demais usos apresentaram baixa relação Ca:Mg. Todavia, devido ao elevado teor de K, encontrado em valor elevado em parte das áreas estudadas, desbalanceou a relação $(\mathrm{Ca}+\mathrm{Mg}): \mathrm{K}$, sendo o valor dessa relação considerado médio apenas nos manejos TCC e CG2, ficando essa relação baixa nos demais usos da terra. Com relação ao $\mathrm{Mg}: \mathrm{K}$ esse desbalanço também ocorreu, sendo essa relação considerada média (entre 2 e 4) nos usos CER, TCC e CG1.

Tabela 18. Relações de $\mathrm{Ca}: \mathrm{Mg}, \mathrm{Mg}: \mathrm{K}$ e $\mathrm{Ca}+\mathrm{Mg}: \mathrm{K}$ nas áreas manejadas sob Cerradão e Cerrado sensu stricto.

\begin{tabular}{|c|c|c|c|c|c|}
\hline \multirow[t]{2}{*}{ Relações } & \multirow{2}{*}{$\begin{array}{l}\text { Profundidade } \\
\text { (cm) }\end{array}$} & \multicolumn{4}{|c|}{ Usos da terra* } \\
\hline & & CER & TCC & CG1 & PB \\
\hline \multirow{2}{*}{$\mathrm{Ca}: \mathrm{Mg}$} & $0-10$ & 1,74 & 3,31 & 3,54 & 1,66 \\
\hline & $10-20$ & 1,59 & 3,75 & 3,34 & 1,13 \\
\hline \multirow{2}{*}{$\mathrm{Mg}: \mathrm{K}$} & $0-10$ & 2,06 & 2,52 & 1,58 & 0,83 \\
\hline & $10-20$ & 1,89 & 1,58 & 2,99 & 0,72 \\
\hline \multirow[t]{2}{*}{$\mathrm{Ca}+\mathrm{Mg}: \mathrm{K}$} & $0-10$ & 5,67 & 10,91 & 7,15 & 1,83 \\
\hline & $10-20$ & 4,12 & 14,07 & 8,00 & 1,47 \\
\hline Relações & & CSS & TSC & CG2 & PNB \\
\hline \multirow{2}{*}{$\mathrm{Ca}: \mathrm{Mg}$} & $0-10$ & 0,37 & 1,48 & 1,67 & 0,92 \\
\hline & $10-20$ & 0,65 & 1,57 & 1,63 & 0,90 \\
\hline \multirow{2}{*}{$\mathrm{Mg}: \mathrm{K}$} & $0-10$ & 1,36 & 1,56 & 5,35 & 1,80 \\
\hline & $10-20$ & 1,21 & 1,85 & 4,78 & 1,93 \\
\hline \multirow[t]{2}{*}{$\mathrm{Ca}+\mathrm{Mg}: \mathrm{K}$} & $0-10$ & 1,86 & 3,85 & 14,30 & 3,45 \\
\hline & $10-20$ & 2,00 & 4,75 & 12,57 & 3,67 \\
\hline
\end{tabular}


Nogara Neto et al. (2011), ao avaliar a importância de atributos de solo na variação espacial de produtividade de grãos de milho, reportaram que o equilíbrio de bases foi importante para a nutrição dessa cultura com reflexos na produtividade. Estes autores relataram a importância da relação $\mathrm{Mg}: \mathrm{K}$, com valor crítico de 2,30, uma vez que a produtividade de milho decresceu quando os valores eram menores que este. Nas áreas cultivadas com milho, observou-se que essa relação foi de 5,29 e de 1,58 em CG2 e CG1, respectivamente. Esse baixo valor da relação em CG1 é provável pela adubação potássica excessiva, tendo o agricultor utilizado como fontes o NPK 4-30-16 no plantio e nitrato de potássio na cobertura, ambos com $16 \%$ e $44 \%$ de $\mathrm{K}_{2} \mathrm{O}$, respectivamente. Já nas culturas perenes, verifica-se que essa relação foi de 1,53 e 2,47 nos manejos TSC e TCC, respectivamente. Esse valor baixo no TSC, também é devido à adubação excessiva de potássio. No PB foi obtida a menor relação $(0,84)$, enquanto que nas áreas nativas essa relação foi de 2,13, 1,86 e 1,36 em CSS, PB e CER, respectivamente.

Ademais, com relação ao $\mathrm{Mg}$, apenas o $\mathrm{PB}$ possui valor baixo, enquanto os demais manejos apresentaram valores adequados de $\mathrm{Mg}$. Em termos de resposta das culturas agrícolas às relações entre cátions básicos no solo, verificou-se que relações equilibradas dos elementos $\mathrm{Ca}, \mathrm{Mg}$ e $\mathrm{K}$ no complexo de troca de um Latossolo Distroférrico de Cambé, PR aumentou a produtividade da cultura da soja (Watanabe et al., 2005). Já para a cultura do milho em solos do Cerrado, os melhores rendimentos foram obtidos com uma relação $\mathrm{Ca}: \mathrm{Mg}$ de 3:1, segundo estudos realizados por (Silva, 1980). A relação Ca:Mg ideal para maioria da culturas é entre 3-5, porém apenas nos manejos TCC $(3,3$, na profundidade de $0-10 \mathrm{~cm})$ e CG1 $(3,5$, na profundidade de $0-10$ $\mathrm{cm})$, apresentaram valor dessa relação na faixa recomendada. 


\subsubsection{Atributos biológicos}

Na tabela 19 são apresentados os valores do carbono orgânico total (COT), carbono da biomassa microbiana $(\mathrm{CBM})$ e quociente microbiano (QmicC) nas áreas manejadas sob Cerradão e no Cerrado sensu stricto.

Tabela 19. Carbono orgânico total (COT), carbono da biomassa microbiana (CBM) e quociente microbiano (QmicC) nas áreas manejadas sob Cerradão e Cerrado sensu stricto.

\begin{tabular}{|c|c|c|c|c|c|}
\hline \multirow{2}{*}{$\begin{array}{l}\text { Atributos } \\
\text { biológicos }\end{array}$} & \multirow{2}{*}{$\begin{array}{c}\text { Profundidade } \\
(\mathrm{cm})\end{array}$} & \multicolumn{4}{|c|}{ Usos da terra* } \\
\hline & & CER & TCC & CG1 & PB \\
\hline \multirow{2}{*}{ COT $\left(\mathrm{g} \mathrm{kg}^{-1}\right)$} & $0-10$ & 61,19 Aa & $38,14 \mathrm{bA}$ & $24,76 \mathrm{cA}$ & $27,89 \mathrm{cA}$ \\
\hline & $10-20$ & $47,30 \mathrm{aB}$ & $38,71 \mathrm{bA}$ & $25,45 \mathrm{cA}$ & $29,31 \mathrm{cA}$ \\
\hline \multirow{2}{*}{$\mathrm{CBM}\left(\mathrm{mg} \mathrm{dm}^{-3}\right)$} & $0-10$ & $532,70 \mathrm{aA}$ & $416,24 \mathrm{bA}$ & $167,57 \mathrm{cA}$ & $439,51 \mathrm{abA}$ \\
\hline & $10-20$ & $202,95 \mathrm{bcB}$ & $446,57 \mathrm{aA}$ & $123,26 \mathrm{cB}$ & $272,22 \mathrm{bB}$ \\
\hline \multirow{2}{*}{ QmicC } & $0-10$ & $0,80 \mathrm{bcA}$ & $1,09 \mathrm{bA}$ & $0,68 \mathrm{cA}$ & $1,59 \mathrm{aA}$ \\
\hline & $10-20$ & $0,41 \mathrm{bB}$ & $1,24 \mathrm{aA}$ & $0,56 \mathrm{bA}$ & $1,38 \mathrm{aA}$ \\
\hline & & CSS & TSC & CG2 & PNB \\
\hline \multirow{2}{*}{$\operatorname{COT}\left(\mathrm{g} \mathrm{kg}^{-1}\right)$} & $0-10$ & $32,97 \mathrm{aB}$ & $30,10 \mathrm{bA}$ & $31,94 \mathrm{abA}$ & $31,01 \mathrm{abB}$ \\
\hline & $10-20$ & $38,39 \mathrm{aA}$ & $29,29 \mathrm{bA}$ & $30,97 \mathrm{bA}$ & $36,65 \mathrm{aA}$ \\
\hline \multirow{2}{*}{$\mathrm{CBM}\left(\mathrm{mg} \mathrm{dm}^{-3}\right)$} & $0-10$ & $309,44 \mathrm{aA}$ & $150,32 \mathrm{bA}$ & $157,07 \mathrm{bA}$ & $358,91 \mathrm{aA}$ \\
\hline & $10-20$ & $258,79 \mathrm{aA}$ & $49,27 \mathrm{~dB}$ & $188,80 \mathrm{bA}$ & $159,62 \mathrm{cB}$ \\
\hline \multirow{2}{*}{ QmicC } & $0-10$ & $0,94 \mathrm{aA}$ & $0,50 \mathrm{bA}$ & $0,49 \mathrm{bB}$ & $1,16 \mathrm{aA}$ \\
\hline & $10-20$ & $0,83 \mathrm{aA}$ & $0,17 \mathrm{cB}$ & $0,62 \mathrm{bA}$ & $0,68 \mathrm{bB}$ \\
\hline
\end{tabular}

Na profundidade de 0-10 cm, o CER apresentou o maior teor de COT (61,2 $\mathrm{g} \mathrm{kg}^{-1}$ ), sendo esse valor $37 \%$ maior do que o obtido no CSS (Cerrado sensu stricto), cujo teor médio foi de $38,4 \mathrm{~g} \mathrm{~kg}^{-1}$ (Tabela 19). Esses resultados demonstram que as diferentes fitofisionomias do Bioma Cerrado, devido à diferença na composição florística que ocasiona maior ou menor aporte de resíduos orgânicos no solo, possuem capacidade distinta de acumular carbono no solo, conforme já documentado por Bustamante et al. (2006).

Nas áreas manejadas sob Cerradão, observa-se que, em ambas as profundidades, o CER apresentou os maiores valores de COT (Tabela 19). Assim, 
verifica-se que ao comparar o COT do CER com os demais tratamentos, houve redução de COT que variou de $37 \%$ a $58 \%$, sendo a menor redução no tratamento TCC, no qual prevaleceu o uso de práticas conservacionistas do solo, o qual apresentou valor de COT significativamente maior do que os usos da terra pautados em manejos convencionais (PB e CG1), em ambas as profundidades (Tabela 19).

Com relação à profundidade, apenas a tangerina com consórcio (TCC) não apresentou diferença de COT entre as profundidades, pois há adição de material orgânico de mais fácil decomposição. É provável que no Cerradão (CER), o padrão observado deve-se a maior deposição de matéria orgânica em superfície, do que em profundidade, pois em superfície há um aporte intensificado de resíduos vegetais mais lignificados em comparação as plantas cultivadas e, também, devido à ausência de influência antrópica na área de Cerradão. No caso dos usos PB e CG1, pautados no manejo convencional do solo, é provável a presença de uma possível camada mais compactada que pode ter favorecido a diminuição das perdas de matéria orgânica por lixiviação nesses sistemas, corroborando os resultados obtidos por Passos et al. (2007).

Nas áreas manejadas no Cerrado sensu stricto, ao comparar o COT do CSS com os demais tratamentos, tendo o COT reduzido significativamente de $19 \%$ e $24 \%$ nos manejos CG2 e TSC, respectivamente (Tabela 19). Ademais, o teor de COT no CN2 foi significativamente semelhante ao do PN na camada de 0-10 cm, tal como ocorreu no TSC e CG2 nas duas profundidades, cujos valores de COT não diferiram significativamente. Todavia, nas áreas nativas (CSS e PNB), os valores de COT foram significativamente maiores na profundidade de $0-10 \mathrm{~cm}$, por possuíram, assim como no CER, um aporte intensificado de resíduos vegetais mais lignificados em comparação as plantas cultivadas.

Vale destacar que os teores médios de COT encontrados nos sistemas CER, CSS, PNB e TCC estão acima dos teores encontrados em Latossolos do Cerrado 
(Figueiredo et al., 2010; Schiavo et al., 2011), com destaque para os elevados teores obtidos no CER (61,2 $\left.\mathrm{g} \mathrm{kg}^{-1}\right)$.

De maneira geral, nos tratamentos (CG1, CG2, TSC e PB), baseados em práticas convencionais de preparo do solo, observaram-se as maiores perdas de COT (Tabela 19). Para Silva et al. (2011), a conversão de áreas de vegetação nativa em cultivo agrícola resultou na diminuição dos teores de COT, sendo essas alterações menores, quando se adota alguma prática conservacionista de preparo do solo, como foi o caso do tratamento TCC.

Com relação ao CBM, o mesmo foi influenciado significativamente pelos diferentes usos da terra e profundidade. Verifica-se que na área sob Cerradão, o menor valor foi no CG1 em ambas às profundidades. Na profundidade de 0-10 $\mathrm{cm}$, o CER apresentou o maior valor de $\mathrm{CBM}$, o qual significativamente semelhante ao $\mathrm{PB}$, que foi semelhante ao TCC. Todavia, na profundidade de 10-20 cm, o CBM foi maior no TCC, enquanto que o cerradão (CER) e a pastagem com braquiária $(\mathrm{PB})$ tiveram valores semelhantes, porém menores que o TCC. Ademais, na profundidade de 10-20 cm, com exceção do TCC, os demais manejos apresentaram CBM maior na camada superficial.

Nas áreas sob Cerrado sensu stricto, o CBM, na profundidade de 0-10 cm, apresentou maior valor no CSS, que significativamente semelhante ao PNB, ficando os manejos convencionais (TSC e CG2) com os menores valores de CBM. Todavia, na profundidade de 10-20 cm, o CSS teve o maior valor de CBM, seguido CG2, PNB, e o TSC, sendo esse último com o menor valor significativo. Com relação à profundidade, com exceção do manejo $\mathrm{CG}$, todos os demais manejos apresentaram CBM significativamente maior na camada superficial do solo.

De maneira geral, verifica-se menor teor de CBM nos sistemas convencionais e maior nas áreas nativas (CER, CSS e PNB), concordando com Ferreira et al. (2011), Pragana et al. (2012) e Godoy et al. (2013). De acordo com Lopes et al. 
(2013), o CBM está adequado nos manejos CER, PB e TCC, moderado em CSS e PNB, e baixo nos demais manejos. Portanto, no solo sob vegetação nativa, a deposição de resíduos orgânicos, a grande quantidade de raízes e a maior quantidade de água retida no solo, nas condições de vegetação nativa, estimulam a manutenção da microbiota do solo, enquanto solos submetidos à atividade agrícola costumam apresentar condições adversas que, normalmente, fazem a população microbiana decrescer (Perez et al., 2004).

A pastagem de braquiária $(\mathrm{PB})$ teve valor médio $\left(439,51 \mathrm{mg} \mathrm{dm}^{-3}\right)$ de CBM próximo ao CER na profundidade de $0-10 \mathrm{~cm}$, isso pode estar relacionado à intensa produção de exsudatos radiculares pelas braquiárias que alimentam a população microbiana, o que corroboram os resultados obtidos por Rambo et al. (2014). Ademais, a PB está em pousio, ficando o solo permanentemente coberto por essa gramínea (Tabela 19).

O QmicC (CBM/COT) reflete o quanto do COT está imobilizado na biomassa microbiana e mostra o potencial de reserva desse elemento no solo (Anderson \& Domsch, 1993). De acordo com a tabela 19, nas áreas manejadas sob Cerradão, verifica-se que o quociente variou de 0,68 a $1,59 \%$ e de 0,41 a $1,38 \%$ nas profundidades de 0-10 e 10-20 cm, respectivamente. Nas áreas sob Cerrado sensu stricto, o quociente variou de 0,49 a $1,16 \%$ e de 0,17 a $0,83 \%$ nas profundidades de 0 10 e 10-20 cm, respectivamente. Observa-se que, de maneira geral, o QmicC foi menor na profundidade de $10-20 \mathrm{~cm}$, tendo em vista que os teores de COT foram menores nessa profundidade.

Nas áreas sob Cerradão e sob Cerrado sensu stricto, verifica-se ainda que o valor dessa relação aumentou na seguinte ordem $\mathrm{CG} 1 \leq \mathrm{CER} \leq \mathrm{TCC}<\mathrm{PB} \quad \mathrm{e}$ $\mathrm{CG} 2=\mathrm{TSC}<\mathrm{CSS} \leq \mathrm{PNB}$, na profundidade de $0-10 \mathrm{~cm}$, sendo os maiores valores encontrados nas áreas de pastagem de braquiária $(\mathrm{PB})$ e nativa (PNB), indicando a 
maior conversão de COT em CBM nas áreas de pasto, o que pode estar sendo influenciado pelo maior número de raízes e produção de exsudatos.

Já os menores valores do quociente QmicC, encontrados nos manejos convencionais (CG2, TSC e CG1), indicam que a biomassa do solo está sob algum fator de estresse, com a capacidade de utilização de COT diminuída, reduzindo assim essa relação (Anderson \& Domsch, 1993). Todavia, segundo Gama-Rodrigues \& GamaRodrigues (2008) em solos com matéria orgânica de difícil decomposição, a biomassa microbiana encontra-se sob estresse e é incapaz de utilizar totalmente o COT, nesse caso o QmicC tende a diminuir. Esse comportamento talvez explique o ocorrido nas áreas nativas (CER e CSS).

Os teores de NT na profundidade de 0-10 e de 10-20 $\mathrm{cm}$ variaram de 1,43 a $3,57 \mathrm{~g} \mathrm{~kg}^{-1}$ e de 1,32 a $3,53 \mathrm{~g} \mathrm{~kg}^{-1}$, respectivamente, não havendo diferenciação entre as profundidades somente no PCs (Tabela 20). Os maiores valores de NT foram encontrados nas áreas manejadas no Cerradão $(\mathrm{CER}>\mathrm{TCC}>\mathrm{CG} 1>\mathrm{PB})$, enquanto que nos manejos sob Cerrado sensu stricto, o NT foi semelhante aos usos da terra e as profundidades, com exceção do CG2 que apresentou maiores valores na profundidade de $0-10 \mathrm{~cm}$.

Nas áreas sob Cerradão, a redução dos teores de NT, em relação ao CER, foi de $14 \%, 33 \%$ e $47 \%$ no TCC, CG1 e PB, respectivamente, na profundidade de $0-10 \mathrm{~cm}$. Enquanto que nos demais sistemas essa redução foi em média de 52\%. Resultados semelhantes foram encontrados por Pragana et al. (2012).

Os valores do nitrogênio da biomassa (NBM) encontram-se na tabela 20, com diferença significativa entre os usos, mas sem diferença entre as profundidades. Nas áreas manejadas sob Cerradão, os maiores valores de NBM foram obtidos no CER $\left(109,85 \mathrm{mg} \mathrm{kg}^{-1}\right)$. A redução dos teores de NBM em comparação ao CER foi de $47 \%$ no $\mathrm{PB}$, cerca de $50 \%$ no $\mathrm{TCC}$, e de $75 \%$ no $\mathrm{CG} 1$, o qual apresentou menor valor 
significativo de NBM. Nas áreas sob Cerrado sensu stricto, verifica-se que o TSC apresentou o menor valor significativo de NBM, enquanto que os demais manejos tiveram comportamento semelhante, apresentando o maior valor de NBM, em ambas as profundidades.

Tabela 20. Nitrogênio total (NT), nitrogênio da biomassa microbiana (NBM) e quociente microbiano (QmicN) nas áreas manejadas sob Cerradão e Cerrado sensu stricto.

\begin{tabular}{|c|c|c|c|c|c|c|}
\hline \multirow{2}{*}{$\begin{array}{l}\text { Atributos } \\
\text { biológicos }\end{array}$} & \multirow{2}{*}{$\begin{array}{l}\text { Profundidade } \\
\text { (cm) }\end{array}$} & \multicolumn{4}{|c|}{ Manejos* } & \multirow[b]{2}{*}{ Média } \\
\hline & & CER & TCC & CG1 & PB & \\
\hline \multirow{2}{*}{$\mathrm{NT}\left(\mathrm{g} \mathrm{kg}^{-1}\right)$} & $0-10$ & $3,43 \mathrm{aA}$ & $2,95 \mathrm{bA}$ & $2,27 \mathrm{cA}$ & $1,79 \mathrm{dA}$ & \\
\hline & $10-20$ & $2,68 \mathrm{bB}$ & $3,27 \mathrm{aA}$ & $1,82 \mathrm{cB}$ & $1,58 \mathrm{cB}$ & \\
\hline \multirow{2}{*}{$\mathrm{NBM}\left(\mathrm{mg} \mathrm{dm}^{-3}\right)$} & $0-10$ & 115,87 & 57,40 & 32,31 & 61,97 & $66,99 \mathrm{~A}$ \\
\hline & $10-20$ & 103,83 & 47,39 & 33,84 & 54,85 & $59,86 \mathrm{~B}$ \\
\hline Média & & $109,85 \mathrm{a}$ & $52,40 \mathrm{~b}$ & $32,85 \mathrm{c}$ & $58,41 \mathrm{~b}$ & \\
\hline \multirow{3}{*}{ QmicN } & $0-10$ & $3,39 \mathrm{aA}$ & $1,96 \mathrm{bA}$ & $1,42 \mathrm{bB}$ & $3,42 \mathrm{aA}$ & \\
\hline & $10-20$ & $3,88 \mathrm{aA}$ & $1,44 \mathrm{bB}$ & $1,85 \mathrm{bA}$ & $3,46 \mathrm{aA}$ & \\
\hline & & CSS & TSC & CG2 & PNB & \\
\hline \multirow{2}{*}{$\mathrm{NT}\left(\mathrm{g} \mathrm{kg}^{-1}\right)$} & $0-10$ & $1,59 \mathrm{aA}$ & $1,73 \mathrm{aA}$ & $1,55 \mathrm{aA}$ & $1,68 \mathrm{aA}$ & \\
\hline & $10-20$ & $1,58 \mathrm{aA}$ & $1,55 \mathrm{aA}$ & $1,37 \mathrm{aB}$ & $1,55 \mathrm{aA}$ & \\
\hline \multirow{2}{*}{$\mathrm{NBM}\left(\mathrm{mg} \mathrm{dm}^{-3}\right)$} & $0-10$ & $55,28 \mathrm{aA}$ & $29,09 \mathrm{bA}$ & $53,09 \mathrm{aA}$ & $55,62 \mathrm{aA}$ & \\
\hline & $10-20$ & $40,88 \mathrm{aA}$ & $20,75 \mathrm{bB}$ & $49,36 \mathrm{aA}$ & $46,19 \mathrm{aB}$ & \\
\hline \multirow{2}{*}{ QmicN } & $0-10$ & 3,50 & 1,70 & 3,43 & 3,32 & $2,99 \mathrm{~A}$ \\
\hline & $10-20$ & 2,57 & 1,35 & 3,58 & 2,98 & $2,62 \mathrm{~B}$ \\
\hline Média & & $3,04 \mathrm{a}$ & $1,52 \mathrm{~b}$ & $3,51 \mathrm{a}$ & $3,15 \mathrm{a}$ & \\
\hline
\end{tabular}

Observa-se que a pastagem de braquiárias (PB) teve valores altos de $\mathrm{CBM}$ e NBM devido à maior quantidade das raízes que proporciona maior exsudação de compostos orgânicos, que servem como fonte de $\mathrm{C}$ e energia à biomassa microbiana do solo.

Para o quociente QmicN (NBM/NT) verifica-se que houve diferença entre os manejos e profundidades (Tabela 20). Nas áreas manejadas sob cerradão, o maior valor foi no CER e PB em ambas as profundidades, enquanto que os demais manejos foram significativamente semelhantes e apresentaram o menor valor do quociente. Nas 
áreas sob cerrado sensu stricto, o menor valor foi no TSC, sendo os demais manejos semelhantes, apresentando o maior valor do quociente.

Segundo Sparling (1992), quanto maior for o QmicN, melhor será a qualidade da matéria orgânica do solo (MOS). Isso justifica o fato das áreas nativas terem apresentado maiores valores desse quociente, porém, no caso do manejo CG2, o aporte de nitrogênio por adubação foi insuficiente, enquanto que na pastagem de braquiárias (PB) não houve adubação, o que conferiu maior valor dessa relação, o que não significa melhor qualidade da MOS. Já nos manejos TSC, CG1 e TCC observa um maior aporte de $\mathrm{N}$ via adubação que culminou na diminuição dessa relação. Segundo Coser et al. (2007), a razão NBM:NOT pode ser alterada pela fertilização nitrogenada, bem como pela queima e manejo do solo e queima dos restos culturais (Barbosa, 2010).

Dados da relação Cmic/Nmic estão na Tabela 21, havendo diferenças entre manejos e profundidades. Nas áreas sob Cerradão verifica que a relação variou de 4,61 a 7,39 e de 1,95 a 10,13 nas profundidades de 0-10 e 10-20 cm, respectivamente. Nas áreas sob Cerrado sensu stricto verifica que a relação variou de 2,99 a 6,49 e de 2,47 a 6,58 nas profundidades de 0-10 e 10-20 cm. Essa relação tendeu a diminuir em profundidade, com exceção de CSS, CG2 e TCC. Os maiores valores dessa relação foram encontrados no PB e PNB. Para Teixeira et al. (2011) a alteração dessa relação evidencia que a composição da comunidade microbiana do solo e, consequentemente o nível de imobilização e mineralização dos nutrientes do solo são afetados pela espécie de planta cultivada e pelo revolvimento do solo.

A facilidade ou não de decomposição da MOS está diretamente ligada à relação $\mathrm{C} / \mathrm{N}$ do solo, cujos valores encontram-se na Tabela 21. A relação $\mathrm{C} / \mathrm{N}$ variou entre manejos e profundidades, sendo as menores encontradas nas áreas manejadas sob cerradão (CER, CG1, PB e TCC), que variaram de 10,9 a 15,5 e as maiores foram sob 
cerrado sensu stricto, que variaram de 17,6 a 20,9, na profundidade de $0-10 \mathrm{~cm}$. Na profundidade de 10-20 cm a relação aumentou com exceção do manejo PCs.

Tabela 21. Relações $\mathrm{Cmic/Nmic} \mathrm{e} \mathrm{C} / \mathrm{N}$ nas áreas manejadas sob Cerradão e Cerrado sensu stricto.

\begin{tabular}{|c|c|c|c|c|c|}
\hline \multirow{2}{*}{$\begin{array}{l}\text { Atributos } \\
\text { biológicos }\end{array}$} & \multirow{2}{*}{$\begin{array}{l}\text { Profundidade } \\
\text { (cm) }\end{array}$} & \multicolumn{4}{|c|}{ Manejos* } \\
\hline & & CER & TCC & CG1 & PB \\
\hline \multirow{2}{*}{ Cmic/Nmic } & $0-10$ & $4,61 \mathrm{bA}$ & $7,33 \mathrm{aA}$ & $5,29 \mathrm{abA}$ & 7,39 aA \\
\hline & $10-20$ & $1,95 \mathrm{bB}$ & $10,13 \mathrm{aA}$ & $3,74 \mathrm{bB}$ & $5,07 \mathrm{bB}$ \\
\hline \multirow{3}{*}{$\mathrm{C} / \mathrm{N}$} & $0-10$ & $13,81 \mathrm{abB}$ & $13,10 \mathrm{bA}$ & $10,90 \mathrm{cB}$ & $15,52 \mathrm{aA}$ \\
\hline & $10-20$ & $22,88 \mathrm{aA}$ & $11,84 \mathrm{cA}$ & $14,03 \mathrm{cA}$ & $18,62 \mathrm{bA}$ \\
\hline & & CSS & TSC & CG2 & PNB \\
\hline \multirow{2}{*}{ Cmic/Nmic } & $0-10$ & $5,61 \mathrm{aA}$ & $5,25 \mathrm{aA}$ & $2,99 \mathrm{bA}$ & $6,49 \mathrm{aA}$ \\
\hline & $10-20$ & $6,58 \mathrm{aA}$ & $2,47 \mathrm{bB}$ & $3,99 \mathrm{bA}$ & $3,53 \mathrm{bB}$ \\
\hline \multirow{2}{*}{$\mathrm{C} / \mathrm{N}$} & $0-10$ & $20,88 \mathrm{aB}$ & $17,59 \mathrm{bA}$ & $20,69 \mathrm{abA}$ & $18,55 \mathrm{abB}$ \\
\hline & $10-20$ & $24,47 \mathrm{Aa}$ & $19,04 \mathrm{bA}$ & $22,59 \mathrm{abA}$ & $23,75 \mathrm{aA}$ \\
\hline
\end{tabular}

A relação $\mathrm{C} / \mathrm{N}$ tem sido o atributo mais usado em modelos para prever a disponibilidade de $\mathrm{N}$ no solo durante a decomposição de materiais orgânicos (Nicolardot et al., 2001). Segundo Moreira e Siqueira (2002), valores de relação C/N acima de 20 indica predomínio do processo de imobilização, que ocorreu nos manejos CSS e CG2. Para Giacomini et al. (2003) o valor ideal para o equilíbrio desse processo seria entre 25 e 30. Nos demais manejos, pode-se inferir que, a mineralização deverá superar a imobilização, resultando em aumento da disponibilidade de $\mathrm{N}$ no solo durante a decomposição dos resíduos culturais, o que explicaria os maiores valores de NT encontrados nesses manejos.

$\mathrm{Na}$ área sob Cerradão, a respiração basal (RB) variou de 2,95 a 11,60 mg C$\mathrm{CO}_{2} \mathrm{~kg}^{-1} \mathrm{~h}^{-1}$ e de 2,12 a 8,30 mg C-CO $\mathrm{kg}^{-1} \mathrm{~h}^{-1}$, nas profundidades de 0-10 a 10-20 cm, respectivamente (Tabela 22). Em ambas as profundidades, verifica-se que a respiração aumentou na seguinte ordem $\mathrm{CG} 1 \leq \mathrm{TCC}<\mathrm{PB} \leq \mathrm{CER}$. Ademais, a RB foi igual nas duas profundidades no manejo CG1, porém diminui com a profundidade nos manejos CER e PB e aumentou no manejo TSC. Enquanto que no cerrado sensu stricto, a RB variou de 
2,77 a 7,07 mg C-CO $\mathrm{kg}^{-1} \mathrm{~h}^{-1}$ e de 3,68 a 10,31 $\mathrm{mg} \mathrm{C}-\mathrm{CO}_{2} \mathrm{~kg}^{-1} \mathrm{~h}^{-1}$, nas profundidades de 0-10 a 10-20 cm, respectivamente (Tabela 22), com diferenças significativas entre os usos da terra e profundidades. Na profundidade de $0-10 \mathrm{~cm}$, verifica-se que a respiração aumentou na seguinte ordem $\mathrm{CG} 2 \leq \mathrm{TSC}<\mathrm{CSS} \leq \mathrm{PNB}$. Na profundidade de $10-20 \mathrm{~cm}$ esse aumento foi na seguinte ordem $\mathrm{CG} 2 \leq \mathrm{TSC} \leq \mathrm{PNB}<\mathrm{CSS}$, havendo aumento significativo da RB, em todos os manejos, com o aumento da profundidade. Araújo et al. (2007), Carneiro et al. (2008) e Chaves et al. (2012), que, também, evidenciaram tendência de superioridade da atividade microbiana, em solos sob pastagem, quando comparados a solos sob cultivos convencionais e áreas com vegetação nativa. Ademais, para Lopes et al. (2013), os valores de RB foram considerados baixos em todos os manejos estudados.

Tabela 22. Respiração basal (RB) nas áreas manejadas sob Cerradão e Cerrado sensu stricto.

\begin{tabular}{lccccc}
\hline \multirow{2}{*}{ Atributos biológicos } & $\begin{array}{c}\text { Profundidade } \\
(\mathbf{c m})\end{array}$ & $\mathbf{C E R}$ & TCC & CG1 & PB \\
\cline { 3 - 6 } & $0-10$ & $11,60 \mathrm{aA}$ & $3,01 \mathrm{bB}$ & $2,95 \mathrm{bA}$ & $11,28 \mathrm{aA}$ \\
\multirow{2}{*}{$\mathrm{RB}\left(\mathrm{mg} \mathrm{C}-\mathrm{CO}_{2} \mathrm{~kg}^{-1} \mathrm{~h}^{-1}\right)$} & $10-20$ & $8,30 \mathrm{aB}$ & $5,50 \mathrm{bA}$ & $2,12 \mathrm{cA}$ & $7,34 \mathrm{abB}$ \\
\hline & $0-10$ & $\mathbf{C S S}$ & TSC & CG2 & PNB \\
\hline \multirow{2}{*}{$\mathrm{RB} \mathrm{mg}\left(\mathrm{C}-\mathrm{CO}_{2} \mathrm{~kg}^{-1} \mathrm{~h}^{-1}\right)$} & $10-20$ & $7,02 \mathrm{aB}$ & $3,62 \mathrm{bA}$ & $2,77 \mathrm{bA}$ & $7,07 \mathrm{aA}$ \\
& $10,31 \mathrm{aA}$ & $4,82 \mathrm{bcA}$ & $3,68 \mathrm{cA}$ & $6,44 \mathrm{bA}$ \\
\hline *CER: cerradão; TCC: tangerina com consórcio; PB: pastagem com braquiárias; CG1: plantio convencional de grãos; CSS: \\
Cerrado sensu stricto; TSC: tangerina sem consórcio; PNB: pastagem de plantas nativas e braquiárias; CG2: plantio \\
convencional de grãos. Médias seguidas de mesma letra minúscula comparam os usos em uma mesma profundidade e \\
maiúscula comparam os usos dentro de cada profundidade (Tukey; p<0,05).
\end{tabular}

Segundo Follet \& Schimell (1989) a maior liberação de $\mathrm{CO}_{2}$ geralmente é devido à maior atividade biológica que, por sua vez, está relacionada diretamente com a quantidade de carbono lábil existente no solo. Entretanto, para Parkin et al. (1996) elevados valores de RB nem sempre indicam condições desejáveis, pois uma alta taxa de RB pode significar, em curto prazo, liberação de nutrientes para as plantas e, em longo prazo, perda de carbono orgânico do solo para atmosfera.

Os teores de glomalina facilmente extraível (Glo) encontram-se na Tabela 23, havendo diferenças entre manejos e profundidades apenas nas áreas sob Cerradão. No Cerradão, o CER apresentou maiores teores de glomalina na profundidade de $0-10$ 
$\mathrm{cm}\left(2,49 \mathrm{~g} \mathrm{~kg}^{-1}\right)$ e os menores valores foram no PB. Na profundidade de $10-20 \mathrm{~cm}$, os teores de Glo foram maiores no TCC e menores nas outras áreas.

No Cerrado sensu stricto, os teores de glomalina facilmente extraível foram maiores na PNB, e menores nos demais usos da terra, sendo os valores de Glo maiores na profundidade de $10-20 \mathrm{~cm}$.

Tabela 23. Glomalina facilmente extraível (Glo) nas áreas manejadas sob Cerradão e Cerrado sensu stricto.

\begin{tabular}{ccccccc}
\hline \multirow{2}{*}{$\begin{array}{c}\text { Atributos } \\
\text { biológicos }\end{array}$} & $\begin{array}{c}\text { Profundidade } \\
(\mathbf{c m})\end{array}$ & CER & TCC & CG1 & PB & \\
\cline { 3 - 7 } & $0-10$ & $2,49 \mathrm{aA}$ & $2,02 \mathrm{bA}$ & $1,73 \mathrm{bcA}$ & $1,39 \mathrm{cA}$ & \\
\multirow{2}{*}{ Glo $\left(\mathrm{mg} \mathrm{kg}^{-1}\right)$} & $10-20$ & $1,18 \mathrm{bB}$ & $1,86 \mathrm{aA}$ & $1,38 \mathrm{bB}$ & $1,29 \mathrm{bA}$ & \\
& & CSS & TSC & CG2 & PNB & Média \\
\hline \multirow{2}{*}{ Glo $\left(\mathrm{mg} \mathrm{kg}^{-1}\right)$} & $0-10$ & 2,58 & 2,77 & 2,85 & 3,31 & $2,28 \mathrm{~A}$ \\
& $10-20$ & 3,21 & 2,92 & 3,20 & 3,87 & $3,30 \mathrm{~B}$ \\
\hline Média & & $2.80 \mathrm{~b}$ & $2,85 \mathrm{~b}$ & $3,03 \mathrm{~b}$ & $3,59 \mathrm{a}$ & \\
\hline
\end{tabular}

*CER: cerradão; TCC: tangerina com consórcio; PB: pastagem com braquiárias; CG1: plantio convencional de grãos; CSS: Cerrado sensu stricto; TSC: tangerina sem consórcio; PNB: pastagem de plantas nativas e braquiárias; CG2: plantio convencional de grãos. Médias seguidas de mesma letra minúscula comparam os usos em uma mesma profundidade e maiúscula comparam os usos dentro de cada profundidade (Tukey; $\mathrm{p}<0,05$ ).

Os mecanismos que regulam a produção de glomalina pelos fungos micorrízicos arbusculares (FMA) ainda não estão bem compreendidos, contudo fatores que afetam a simbiose micorrízica possivelmente devem também influenciar na produção desta proteína pelos FMA. Alguns autores (Rillig et al., 2003; Haddad \& Sarkar, 2003) observaram correlação negativa entre concentrações de glomalina e pH do solo, já que fungos tendem a predominar em solos ácidos.

Vale constar que as áreas manejadas sob Cerradão, com elevado teor de K, também apresentaram maiores valores de NT. Para Lovelock et al. (2004), em condições de maior disponibilidade de nutrientes, principalmente $\mathrm{N}$ e $\mathrm{P}$, sinais moleculares emitidos pela planta hospedeira são afetados, reduzindo os sítios de infecção e o estabelecimento da associação micorrízica, o que consequentemente afeta a produção de glomalina pelos FMA. 


\subsubsection{Análise multivariada}

Os diferentes manejos estudados foram afetados pelos atributos físicos, químicos e biológicos do solo, conforme constatado na análise univariada. A relação entre esses atributos e os usos da terra foi testada, utilizando-se a RDA. Essa análise foi empregada para avaliar as possíveis relações existentes entre os atributos químicos e físicos, considerados como variáveis explicativas, com os atributos biológicos, considerados como variáveis respostas, em áreas sob diferentes usos da terra.

Para tanto, aplicou-se a seleção de variáveis explicativas com o teste de permutação de Monte Carlo, que fornece um teste de significância para as variáveis estudadas. Na seleção de variáveis, os atributos $\mathrm{Al}, \mathrm{Ca}, \mathrm{Mg}, \mathrm{V}, \mathrm{m}, \mathrm{pH}, \mathrm{Ds}, \mathrm{Dp}, \mathrm{CTC}$; e $\mathrm{Al}, \mathrm{Ca}, \mathrm{H}+\mathrm{Al}, \mathrm{V}, \mathrm{m}, \mathrm{CTC}$ e SB, nas profundidades de 0-10 e 10-20 cm, respectivamente, foram eliminados por apresentarem efeito de colinearidade, ou seja, estas variáveis apresentaram alta correlação com outras variáveis explicativas e, portanto, não contribuíram para o resultado da análise.

De acordo com a Figura 22, verifica-se que na profundidade de 0-10 cm, a RDA representou 55,2\% da variabilidade dos dados (F-ratio $=10,774 ; \mathrm{P}$ value $=0.002)$. Desta variabilidade, sem considerar a influência das variáveis explicativas, 45,9\% estão representados nos dois primeiros eixos, sendo $25,7 \%$ representado pelo eixo 1 e 20,2\% pelo eixo 2 (Figura 22). Com a participação das variáveis explicativas a representação da variabilidade pelos eixos canônicos 1 e 2 aumenta para 46,6\% e 46,7\%, respectivamente, totalizando $83,3 \%$ da variabilidade dos dados.

A RDA presente na Figura 22 revela que na profundidade de $0-10 \mathrm{~cm}$ os atributos $\mathrm{Pt}, \mathrm{K}, \mathrm{P}$ e $\mathrm{H}+\mathrm{Al}$ apresentaram correlação significativa $(P<0,01 \%)$ com os atributos biológicos, influenciados pelos usos da terra. O CER apresentou os maiores valores dos atributos biológicos, especialmente COT, CBM, NBM, RB, Qmic C e CmicNmic, os quais se relacionaram positivamente com a acidez potencial do solo. $\mathrm{O}$ 
CSS e o PNB ficaram agrupadas, estando relacionadas aos maiores valores de Glo, relação CN e Qmic N, os quais se correlacionaram negativamente ao K, P e Pt.

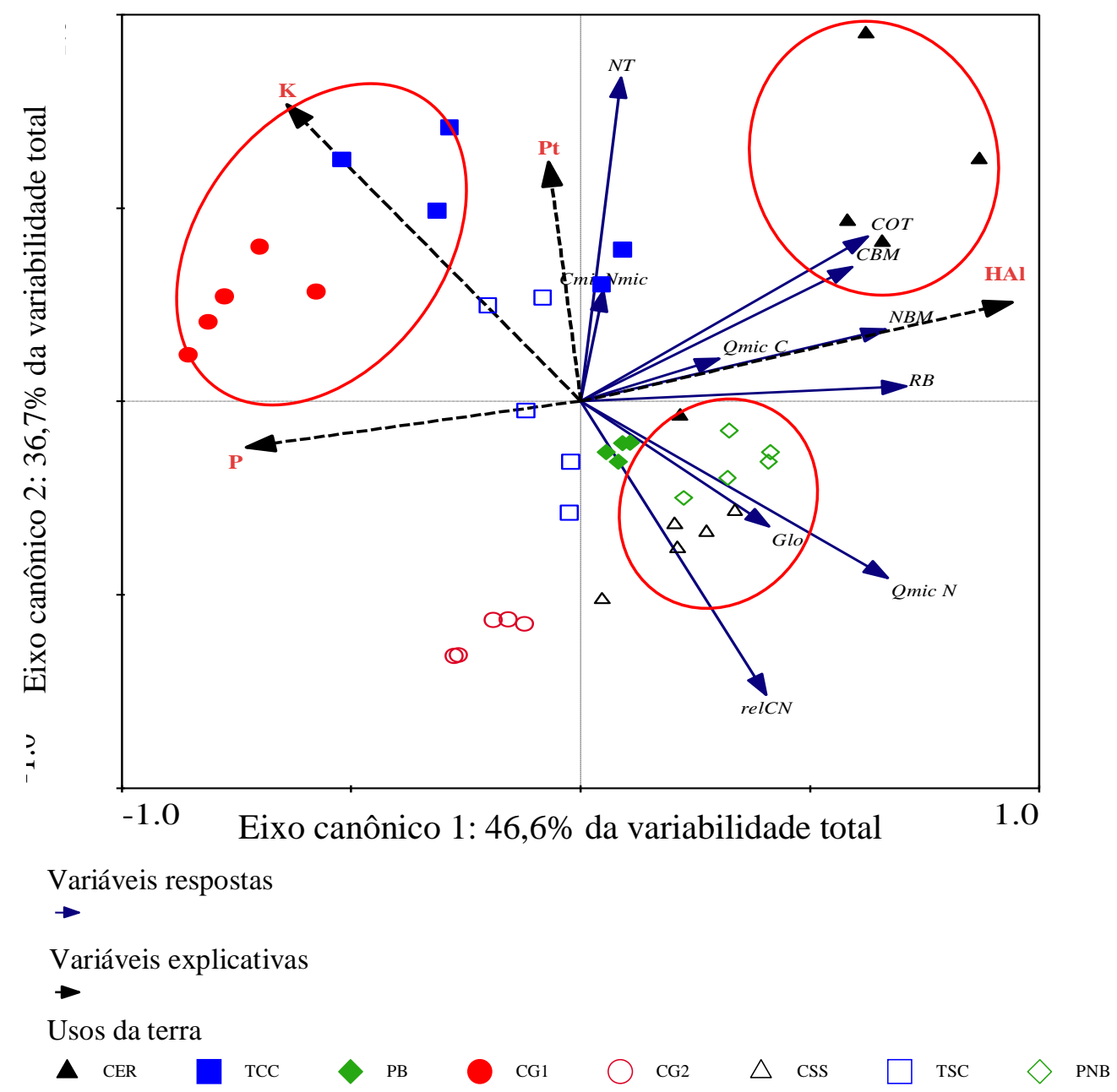

Figura 22. Análise de redundância dos atributos biológicos do solo (COT: carbono orgânico total, NT: nitrogênio total; CBM: carbono da biomassa microbiana, NBM: nitrogênio da biomassa microbiana; RB: respiração basal; Glo: glomalina facilmente extraível; QmicC: quociente microbiano de $\mathrm{C}$ e QmicN: quociente microbiano de $\mathrm{N}$; e relações $\mathrm{CN}$ e $\mathrm{CmicNmic}$ ) ligados aos atributos físicos e químicos do solo ( $\mathrm{HAl}$ : acidez potencial, $\mathrm{P}$ : fósforo; K: potássio e Pt: porosidade total) em diferentes usos da terra (CG1: plantio convencional de grãos; CER: cerradão; TCC: tangerina com consórcio; PB: pastagem com braquiárias; CG2: plantio convencional de grãos, CSS: cerrado sensu stricto; TSC: tangerina sem consórcio; PNB: pastagem de plantas nativas e braquiárias), na profundidade de $0-10 \mathrm{~cm}$. 
A RDA da profundidade de $0-10 \mathrm{~cm}$ revela que o manejo conservacionista (TCC) foi associado aos maiores valores de NT, cujos atributos foram correlacionados positivamente as variáveis $\mathrm{Pt}$ e $\mathrm{K}(\mathrm{K}, \mathrm{pH}, \mathrm{Mg}, \mathrm{SB}$ e $\mathrm{CTC})$ e negativamente pelos atributos biológicos (relação C/N, Glo e Qmic N). O manejos CG1, CG2 e TSC associarem-se aos atributos $\mathrm{K}$, Pt e P, pois são as áreas manejadas quimicamente.

Com relação à profundidade de $10-20 \mathrm{~cm}$, a figura 23 revela que a RDA representou 49,2\% da variabilidade dos dados (F-ratio=5,32; P value=0.002). Desta variabilidade, sem considerar a influência das variáveis explicativas, 39,3\% estão representados nos dois primeiros eixos, sendo $22 \%$ representado pelo eixo 1 e 17,3\% pelo eixo 2 (Figura 22). Com a participação das variáveis explicativas a representação da variabilidade pelos eixos canônicos 1 e 2 aumenta para 44,8\% e 35,1\%, respectivamente, totalizando $79,9 \%$ da variabilidade dos dados.

A RDA presente na figura 23 revela que na profundidade de $10-20 \mathrm{~cm}$ os atributos pH, P, K, Mg, CTC e Ds apresentaram correlação significativa $(P<0,01 \%)$ com os atributos biológicos, influenciando os manejos estudados. O CER continuou apresentando os maiores valores dos atributos biológicos, especialmente COT, CBM, NBM, RB e Qmic C, os quais foram inversamente relacionados com o aumento das variáveis Ds e P. O CSS e o PNB se agruparam ao manejo CG2, estando associados à Glo e relação $\mathrm{CN}$, sendo relacionados com os menores teores e valores das variáveis $\mathrm{K}$, $\mathrm{Mg}, \mathrm{pH}$ e CTC. O TCC obtiveram os maiores valores de NT e CmicNmic correlacionados positivamente a CTC, $\mathrm{pH}, \mathrm{Mg}$ e $\mathrm{K}$. Os manejos CG1 e TSC ficaram agrupadas, estando associadas aos atributos P e Ds, tendo obtido os maiores valores para essas variáveis. O PB foi o manejo que apresentou os menores valores dos atributos estudados, mais próximas da média geral dos dados. 


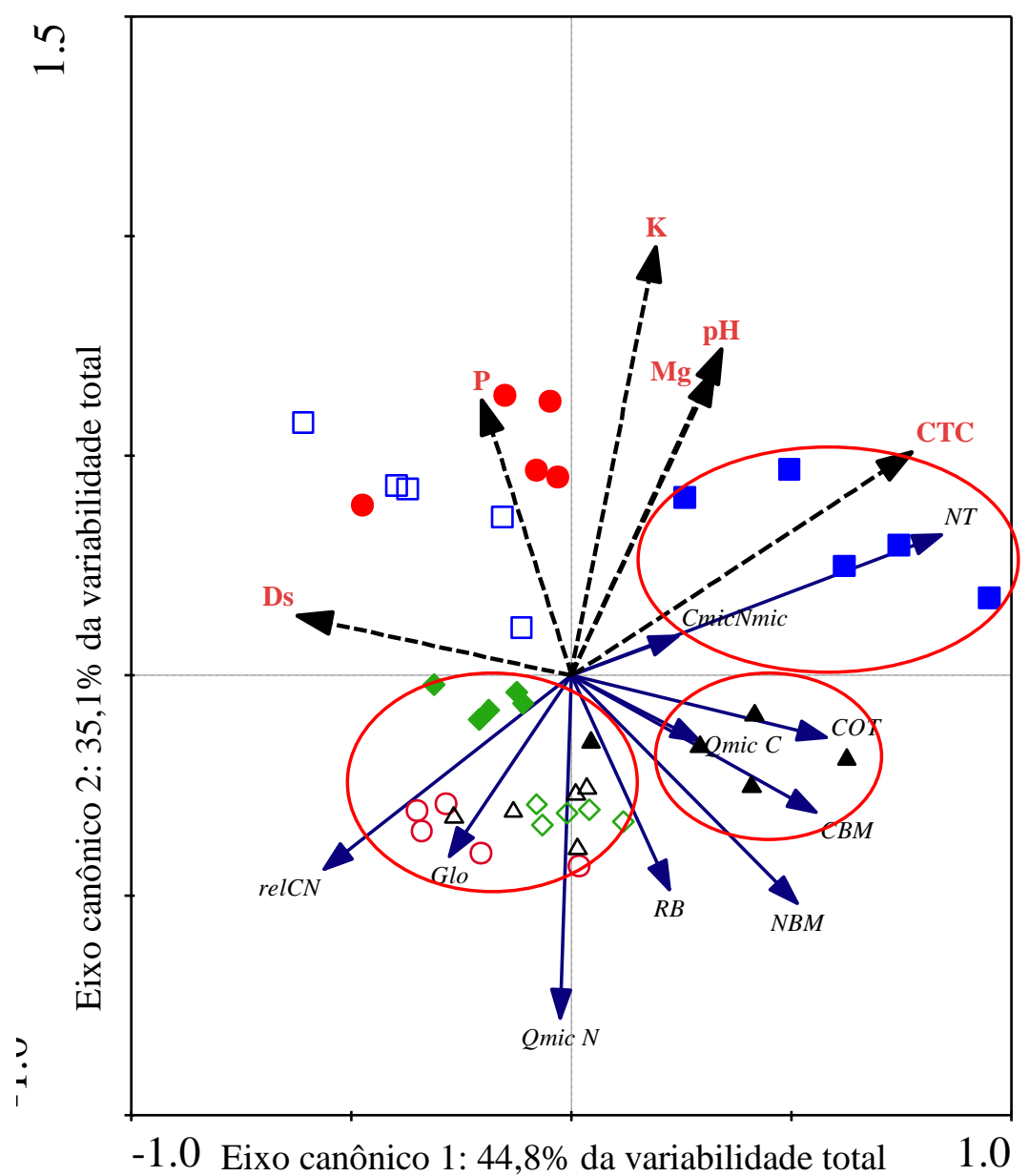

Variáveis respostas

Variáveis explicativas

$\overrightarrow{\text { Usos da terra }}$

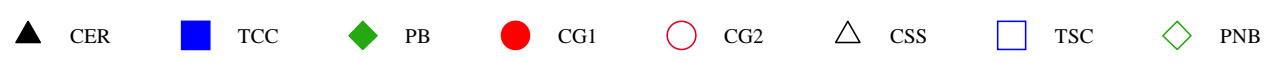

Figura 23. Análise de redundância dos atributos biológicos do solo (COT: carbono orgânico total, NT: nitrogênio total; CBM: carbono da biomassa microbiana, NBM: nitrogênio da biomassa microbiana; RB: respiração basal; Glo: glomalina facilmente extraível; QmicC: quociente microbiano de $\mathrm{C}$ e QmicN: quociente microbiano de $\mathrm{N}$; e relações $\mathrm{CN}$ e $\mathrm{CmicNmic}$ ) ligados aos atributos físicos e químicos do solo (HAl: acidez potencial, P: fósforo; K: potássio e Pt: porosidade total) em diferentes usos da terra (CG1: plantio convencional de grãos; CER: cerradão; TCC: tangerina com consórcio; PB: pastagem com braquiárias; CG2: plantio convencional de grãos, CSS: cerrado sensu stricto; TSC: tangerina sem consórcio; PNB: pastagem de plantas nativas e braquiárias), na profundidade de $10-20 \mathrm{~cm}$. 


\subsection{CONCLUSÕES}

1. Os usos da terra com sistema de produção convencional (plantio convencional de grãos 1 e 2; tangerina sem consórcio e pastagem de braquiárias) promoveram alterações nos atributos estudados, sendo que o uso da terra com sistema de produção conservacionista (tangerina com consórcio) foi o que menos impactou os atributos físicos, químicos e biológicos.

2. A aplicação da análise redundância canônica ressaltou na profundidade de $0-10$ $\mathrm{cm}$, maior semelhança entre a tangerina com consórcio e o plantio convencional de grão 1, e, os demais usos, com exceção do cerradão, agruparam-se. Na profundidade de 10-20 cm, a tangerina sem consórcio não se agrupou com os demais usos da terra, diferenciando-se dos demais manejos.

3. A análise de redundância também revelou que os atributos ( $\mathrm{Ds}, \mathrm{Pt}, \mathrm{K}, \mathrm{Mg}, \mathrm{P}$, $\mathrm{pH}, \mathrm{H}+\mathrm{Al}$ e CTC) relacionaram-se significativamente aos atributos biológicos que discriminaram os usos da terra adotados pelos quilombolas.

\subsection{REFERÊNCIAS BIBLIOGRÁFICAS}

ANDERSON, J. P. E.; DOMSCH, K. H. The metabolic quotient of CO2 (q CO2) as a specific activity paramenter to assess the effects of environmental condition, such as $\mathrm{pH}$, on the microbial of forest soil. Soil Biology and Biochemistry, v. 25, n. 3, 1993, p. 393-395.

ARAÚJO, R.; GOEDERT, W.J. \& LACERDA, M.P.C. Qualidade de um solo sob diferentes usos e sob cerrado nativo. R. Bras. Ci. Solo, v. 31, 2007, p. 1099-1108.

AUDEH, S., LIMA, A. C. R., CARDOSO, I. M., CASALINHO, H. D., JUCKSCH, J. Qualidade do solo: uma visão etnopedológica em propriedades agrícolas familiares produtoras de fumo orgânico Revista Brasileira de Agroecologia. v. 6, n.3, 2011, p. 3448. 
BARBOSA, I. O.; LACERDA, M. P. C. Relações pedomorfogeológicas nas Chapadas Elevadas do Distrito Federal. Revista Brasileira de Ciência do Solo, v.33, 2009, p.273 283.

BARBOSA, L. de A. Impacto de sistemas de cultivo orgânica e convencional da canade-açúcar, nos atributos do solo. 2010. Dissertação (Mestrado em Agronomia) Faculdade de Agronomia e Medicina Veterinária. Universidade de Brasília, Distrito Federal.

CAMARGO, O.A. de; ALLEONI, L.R.F. Compactação do solo e o desenvolvimento das plantas. Piracicaba, ESALQ/USP, 1997. 132p.

CAMPOS, P. M.; LACERDA, M. P. C.; SILVA, C. L.; SÁ, M. A. C DE; SOUSA, D. M. G. de. A drenagem interna como fator de diferenciação dos Latossolos do Distrito Federal. Pesquisa Agropecuária Brasileira, v.45, 2010, p.306-314.

CARNEIRO, M.A.C.; MELO, L.B.C.; ASSIS, P.C.R.; PEREIRA, H.S.; PAULINO, H.B.; SILVEIRA NETO, A.N. Atributos bioquímicos em dois solos de Cerrado sob diferentes sistemas de manejo e uso. Pesquisa Agropecuária Tropical, Goiânia, v. 38. n. 4, 2008, p. 276-283.

CARNEIRO, M.A.C.; SOUZA, E.D.; REIS, E.F.; PEREIRA, H.S.; AZEVEDO, W. Atributos físicos, químicos e biológicos de solo de Cerrado sob diferentes sistemas de uso e manejo. Revista Brasileira de Ciência do Solo, Viçosa, v. 33, n. 1, 2009, p. 147 157.

CHAVES, A. A. A.; LACERDA, M.P.C.; GOEDERT, W.J.; RAMOS, M.L.G.R.; KATO, E. Indicadores de qualidade de Latossolo Vermelho sob diferentes usos. Pesquisa Agropecuária Tropical, Goiânia, v. 42, n. 4, 2012, p. 446-454.

COSER, T. R.; RAMOS, M. L. G.; AMABILE, R. F.; RIBEIRO JÚNIOR, W. Q. Nitrogênio da biomassa microbiana em solo de Cerrado com aplicação de fertilizante nitrogenado. Pesquisa Agropecuária Brasileira, v.42, 2007, p.399-406.

COSTA, E.M.; SILVA, H.F.; RIBEIRO, P.R. de A. Matéria orgânica do solo e o seu papel na manutenção e produtividade dos sistemas agrícolas. ENCICLOPÉDIA BIOSFERA, Centro Científico Conhecer - Goiânia, v.9, n.17; 2013, p. 1842-1860. 
COSTA, N.R.; ANDREOTTI, M.; LOPES, K.S.M.; YOKOBATAKE, L.; FERREIRA, J.P.; PARIZ, C.M.; BONINI, C.S.B.; LONGHINI, V.Z. Atributos do Solo e Acúmulo de Carbono na Integração Lavoura-Pecuária em Sistema Plantio Direto. Revista Brasileira de Ciência do Solo. v. 39, 2015, p.852-863.

CUNHA, E. Q.; STONE, L. F.; FERREIRA, E. P. B.; DIDONET, E. D.; MOREIRA, J. A. A. Atributos físicos, químicos e biológicos de solo sob produção orgânica impactados por sistema de cultivo. Revista Brasileira de Engenharia Agrícola e Ambiental, v.16, 2012, p.56-63.

D`ANDRÉA, A. F., SILVA, M.LN.; CURI, N.; SIQUEIRA, J.O.; CARNEIRO, M.A.C. Atributos biológicos indicadores da qualidade do solo em sistema de manejo na região do Cerrado no sul do Estado de Goiás. Revista Brasileira de Ciências do Solo, Viçosa, v. 26, n. 4,2002 , p. 913-923.

DEXTER, A. R. Soil physical quality. Part 1. Theory, effects of soil texture, density, and organic matter, and effects on root growth. Geoderma, v.120, 2004, p.201-214.

DIAS JUNIOR, M.S. \& PIERCE, F.J. Revisão de literatura: O processo de compactação do solo e sua modelagem. R. Bras. Ci. Solo, 20, 1996, p. 175-182.

DIAS, J.E.; ABOUD, A.C.S.; GUERRA, J.G.M.; SALLES, R.R.; Monitoring land use and plant cover on na Integrated Agroecological Production System through GIS.RevistaBrasileiradeAgroecologia,v.5,n.2, 2010, p.275-287.

DORAN, J.W. \& PARKIN, T.B. Defining and assessing soil quality. In: DORAN, J.W.; COLEMAN, D.C.; BEZDICEK, D.F. \& STEWART, B.A., eds. Defining soil quality for a sustainable environment. Madison, SSSA, 1994. p.1-20.

EMBRAPA. Manual de métodos de análises de solo. 2. ed. Rio de Janeiro: Centro Nacional de Pesquisa de Solos, 2011. 212 p.

ESCOSTEGUY, P.A.V. Deficiência de potássio em lavouras de soja do Planalto do Rio Grande do Sul. Revista Plantio Direto, n.127, 2012, p.1-16.

FERREIRA, E. P. B.; WENDLAND, A.; DIDONET, A. D. Microbial biomass and enzyme activity of a Cerrado Oxisol under agroecological production system. Bragantia, v.70, 2011, p.899-907. 
FOLLET, R.F.; SCHIMEL, D.S. Effect of tillage practices on microbial biomass dynamics. Soil Science Society of America Journal, v.53, 1989, p.1091-1096.

FOLONI, J. S. S.; CALONEGO, J. C.; LIMA, S. L. Efeito da compactação do solo no desenvolvimento aéreo e radicular de cultivares de milho. Pesquisa Agropecuária Brasileira, Brasília, DF, v. 38, n. 8, 2003, p. 947-953.

GAMA-RODRIGUES, E.F. \& GAMA-RODRIGUES, A.C. Biomassa microbiana e ciclagem de nutrientes. In: SANTOS, G.A.; SILVA, L.S.; CANELLAS, L.P. \& CAMARGO, F.A.O., eds. Fundamentos da matéria orgânica do solo ecossistemas tropicais e subtropicais. 2.ed. Porto Alegre, Metrópole, 2008. p.159-170.

GIACOMINI, S.J.; AITA, C.; VENDRUSCOLO, E.R.O.; CUBILLA, M.; NICOLOSO, R.S. \& FRIES, M.R. Matéria seca, relação $\mathrm{C} / \mathrm{N}$ e acúmulo de nitrogênio, fósforo e potássio em mistura de plantas de cobertura de solo. R. Bras. Ci. Solo, 27, 2003, p. 325334.

GODOY, S.G.; STONE, L.F.; FERREIRA, E.P.B.; COBUCCI, T.; LACERDA, M.C. Atributos físicos, químicos e biológicos do solo impactado por cultivos sucessivos de arroz. Revista Brasileira Engenharia Agrícola e Ambiental, v.17, n.12, 2013, p.12781285 .

GOEDERT, W. J. Qualidade do solo em sistemas de produção agrícola. In: CONGRESSO BRASILEIRO DE CIÊNCIA DO SOLO, 30., Recife, 2005. Anais... Recife: SBCS, 2005. 1 CD-ROM.

GUIMARÃES, W.D.; GRIPP JUNIOR, J.; MARQUES, E.A.G.; SANTOS, N.T.; FERNANDES, R.B.A. Variabilidade espacial de atributos físicos de solos ocupados por pastagens. Rev. Ciênc. Agron., v. 47, n. 2, 2016, p. 247-255.

HADDAD, M.J. \& SARKAR, D. Glomalin, a newly discovered component of soil organic matter: Part II - Relationship with soil properties. Environ. Geosci., 10, 2003, p. 99-106.

JENKINSON, D.S. \& POWLSON, D.S. The effects of biocidal treatments on metabolism in soil-I. Fumigation with chloroform. Soil Biol. Biochem., 8, 1976, p. 167177. 
LAL, R. Métodos para avaliação do uso sustentável dos recursos solo e água nos trópicos. Jaguariúna: EmbrapaMeio Ambiente, 1999. 97 p.(Documentos 3).

LAURINDO, M. C. O.; NÓBREGA, L. H. P.; PEREIRA, J. O.; MELO, D.; LAURINDO, E. L. Atributos físicos do solo e teor de carbono orgânico em sistemas de plantio direto e cultivo mínimo. Engenharia na Agricultura, Viçosa, v.17 n.5, 2009, p. 367-374.

LEPS, J. \& SMILAUER, P. Multivariate analysis of ecological data. Èeské Budijovice, Faculty of Biological Sciences, University of South Bohemia, 2003. 110p.

LOPES, A.A.C.; SOUSA, D.M.G.; CHAER, G.M.; JUNIOR, F.R.R.; GOEDERT, W.J.; MENDES, I.C. Interpretation of Microbial Indicators As a Function of Crop Yield and Organic Carbon In Cerrado Soils. Soil Science Society American Journal, 2012, p 1-12.

LOVELOCK, C.E.; WRIGHT, S.F. \& NICHOLS, K.A. Using glomalin as an indicator for arbuscular mycorrhizal hyphal growth: an example from a tropical rain forest soil. Soil Biol. Biochem., 36, 2004, p. 1009-1012.

MELO FILHO, J. F. et al. Análise estatística exploratória e variabilidade da densidade do solo em um perfil de Latossolo Amarelo coeso dos tabuleiros costeiros da Bahia. Ciência \& Agrotecnologia, Lavras, v. 30, n. 2, 2006, p. 199-205.

MENDES, F. G.; MELLONI, E. G. P.; MELLONI, R. Aplicação de atributos físicos do solo no estudo da qualidade de áreas impactadas, em Itajubá - MG. Cerne, Lavras, v. 12, n. 3. 2006, p. 211-220.

MERGULHÃO, A.C.E.S.; BURITY, H.A.; SILVA, F.S.B.; PEREIRA, S.V. \& MAIA, L.C. Glomalin production and microbial activity in soils impacted by gypsum mining in a Brazilian semiarid area. Am. J. Agric. Biol. Sci., 5, 2010, p. 422-429.

MOREIRA, F.M.S. \& SIQUEIRA, J.O. Microbiologia e bioquímica do solo. Lavras, Universidade Federal de Lavras, 2002. 625p.

MUNIZ, L. C.; MADARI, B. E.; TROVO, J. B. F.; CANTANHÊDE, I. S. L.; MACHADO, P. L. O. A.; COBUCCI, T.; FRANÇA, A. F. S. Soil biological attributes in pastures of different ages in a crop livestock integrated system. Pesquisa Agropecuária da Paraíba, v.46, 2011, p.1262-1268. 
NICOLARDOT, B.; RECOUS, S.; MARY, B. Simulation of C and N mineralization during crop residue decomposition: A simple dynamic model based on the $\mathrm{C} / \mathrm{N}$ ratio of the residues. Plant and Soil, v. 228, n. 1, 2001, p. 83-103.

NOGARA NETO, F.; ROLOFF , G.; DIECKOW, J.; MOTTA , A.C.V. Atributos de solo e cultura espacialmente distribuídos relacionados ao rendimento do milho. Revista Brasileira de Ciência do Solo, Viçosa, v. 35, 2011, p. 1025-1036.

PAPA, R.A.; LACERDA, M.P.C.; CAMPOS, P.M.; GOEDERT, W.J.; RAMOS, M.L.G.; KATO, E. Qualidade de Latossolos Vermelhos e Vermelho-Amarelos sob vegetação nativa de Cerrado. Pesquisa Agropecuária Tropical, Goiânia, v. 41, n. 4, 2011, p. 564-571.

PARKIN, T.B.; DORAN, J.W.; FRANCOP-VIZCAÍNO, E. Field and laboratory tests of soil respiration. In: DORAN, J.W.; JONES, A. (Ed.). Methods for assessing soil quality. Madison: Soil Science Society of America, 1996. p.231-245.

PEREZ, K.S.; RAMOS, M.L.G.; McMANUS, C. Carbono da biomassa microbiana em solo cultivado com soja sob diferentes sistemas de manejo nos Cerrados. Pesquisa Agropecuária Brasileira, v.39, 2004, p.567-573.

PIGNATARO NETTO, I. T.; KATO, E; GOEDERT,W. J. Atributos físicos e químicos de um latossolo Vermelho-amarelo sob pastagens com diferentes históricos de uso. Revista Brasileira de Ciência do Solo, Viçosa, v. 3, 2009, p. 1441-1448.

PRAGANA, R.B.; NÓBREGA, R.S.A.; RIBEIRO, M.R.; LUSTOSA FILHO, J.F. Atributos Biológicos e Dinâmica da Matéria Orgânica em Latossolos Amarelos na Região do Cerrado Piauiense Sob Sistema Plantio Direto. Revista Brasileira de Ciência do Solo, Viçosa, v.36, 2012, p.851-858.

RAMBO, J.R.; GOUVEIA, R.G.L.; SANTI, A.; BAYER, C. Atributos químicos do solo sob distintos sistemas de manejo de Fertilidade. Enciclopédia Biosfera, Centro Científico Conhecer, Goiânia, v. 10, n. 18, 2014, p. 454.

RILLIG, M.C.; RAMSEY, P.; MORRIS, S. \& PAUL, E. Glomalin, an arbuscularmycorrhizal fungal soil protein, responds to soil-use change. Plant Soil, 253, 2003, p. 293-299. 
SALES, R.P; PORTUGAL, A.F.; MOREIRA, J.A.A.; KONDO, M.K.; PEGORARO, R.F. Qualidade física de um Latossolo sob plantio direto e preparo convencional no semiárido. Revista Ciência Agronômica, v. 47, n. 3, 2016, p. 429-438.

SANTI, A. L., AMADO, T. J. C., CHERUBIN, M. R., MARTIN, T. N., PIRES, J. L., DELLA FLORA, L. P., BASSO, J. Análise de componentes principais de atributos químicos e físicos do solo limitante à produtividade de grãos. Pesquisa Agropecuária Brasileira, v. 47, n. 9, 2012, p. 1346-1357.

SANTOS, M.L.; CARVALHO, M.P.; PAPASSI, R.M.A; MURAISHI, C.T.; MALLER, A.; MATOS, F.A. Correlação linear e espacial entre produtividade de milho (Zea mays L.) e atributos físicos de um Latossolo Vermelho distroférrico sob plantio direto do Cerrado brasileiro. Acta Scientiarum Agronomy, Maringá, v. 28, n. 3, 2006, p. 313-321.

SECCO, D.; Da ROS, C.O.; SECCO, J.K.; FIORIN, J.E. Atributos físicos e produtividade de culturas em um latossolo vermelho argiloso sob diferentes sistemas de manejo. R. Bras. Ci. Solo, 29,2005, p. 407-414.

SHIRATSUCHI, L.S.; MARCHÃO, R.L.; JERKE, C.; RESENDE, A.V.; FONTES, J.R.A.; OLIVEIRA, C.M. de; VILELA, M. de F.; SÁ, M.A.C. de; SANTOS JÚNIOR, J. de D.G. dos; HURTADO, S.M.C. Geração de mapas multitemáticos em agricultura de precisão. Planaltina: Embrapa Cerrados, 2007. 22p. (Embrapa Cerrados. Boletim de pesquisa e desenvolvimento, 181).

SILVA, B.M.; SILVA, E.A.; OLIVEIRA, G.C.; FERREIRA, M.M.; SERAFIM, M.E. Plant-available soil water capacity: estimations methods and implications. Revista Brasileira de Ciência do Solo, Viçosa, v. 38, 2014, p. 464-475.

SILVA, C.F.; SIMÕES-ARAÚJO, J.L.; SILVA, E.M.R.; PEREIRA, M.G.; FREITAS, M.S.M.; SAGGIN JÚNIOR, O.J. \& MARTINS, M.A. Fungos micorrízicos arbusculares e proteína do solo relacionada à glomalina em área degradada por extração de argila e revegetada com eucalipto e acácia. Ci. Flor., 22, 2012, p. 749-761.

SILVA, J.E. Balanço de cálcio e magnésio e desenvolvimento de milho em solos sob cerrado. Pesquisa Agropecuária Brasileira, Brasília, 5(3), 1980, p. 329- 333. 
SILVA. A. S. SILVA, I. F. BANDEIRA, L. B. DIAS, B. O. NETO, L. F. S. Argila e matéria orgânica e seus efeitos na agregação em diferentes usos do solo. Ciência Rural, v. 44 , n. 10, 2014, p. 1783-1789.

SIQUEIRA NETO, M.; PICCOLO, M.C.; SCOPEL, E.; COSTA JUNIOR, C.; CERRI, C.C. \& BERNOUX, M. Carbono total e atributos químicos com diferentes usos do solo no Cerrado. Acta Sci. Agron., 31,2009, p. 709-717, 2009.

SOUSA, D. M. G.; LOBATO, E. Correção da acidez do solo. In: SOUSA, D. M. G.; LOBATO, E. (Eds.). Cerrado: correção do solo e adubação. Brasília, DF: Embrapa, 2004. p. 81-95.

SOUSA, D.M.G.; LOBATO, E. \& REIN, T.A. Adubação com fósforo. In: SOUSA, D.M.G. \& LOBATO, E., eds. Cerrado: correção do solo e adubação. Planaltina, Embrapa Cerrados, 2002. p.147-168.

SPARLING, G.P. Ratio of microbial biomass carbon to soil organic carbon as a sensitive indicator of changes in soil organic matter. Australian Journal of Soil Research, v.30, 1992, p.195-207.

SPERA, S.T.; SANTOS, H.P.; FONTANELI, R.S.; TOMM, G.O. Integração lavourapecuária e os atributos físicos do solo manejado sob sistema plantio direto. Revista Brasileira de Ciência do Solo, Viçosa, v.33, n.1, 2009, p.129-136.

TEIXEIRA, D. D. B.; BICALHO, E. S.; PANOSSO, A. R.; PERILLO, L.I .; IAMAGUTI, J. L.; PEREIRA, G. T.; LA SCALA JR., N. Krigagem ordinária e simulação sequencial Gaussiana na interpolação da emissão de $\mathrm{CO}_{2}$ do solo. Energia na Agricultura, v.26, 2011, p.26-42.

ter BRAAK, C.J.F., SMILAUER, P. CANOCO reference manual and user's guide to Canoco for Windows: software for canonical community ordination, version 4. 1988, New York.

TORRES, J.L.R.; PEREIRA, M.G.; ASSIS, R.L.; SOUZA, Z.M. Atributos físicos de um latossolo vermelho cultivado com plantas de cobertura, em semeadura direta. Revista Brasileira de Ciência do Solo, Viçosa, v. 39, 2015, p. 428-437.

VANCE, E.D.; BROOKES, P.C. \& JENKINSON, D.S. Na extraction method for measuring soil microbial biomass. Soil Biol. Biochem., 19, 1987, p.703-707. 
VEZZANI, F.M. \& MIELNICZUK, J. Uma visão sobre qualidade do solo. Revista Brasileira de Ciência do Solo, Viçosa , v. 33, 2009, p. 743-755.

WATANABE, R.T.; FIORETTO, R.A.; FONSECA, I.B. da; SEIFERT, A.L.; SANTIAGO, D.C.; CRESTE, J.E.; HARADA, A.; CUCOLOTTO, M. Produtividade da cultura de soja em função da densidade populacional e da porcentagem de cátions (Ca, Mg e K) no complexo sortivo do solo. Semina: Ciências Agrárias, v.26, 2005, p.477-484.

WENDLING, B. ; VINHAL-FREITAS, I.C.; OLIVEIRA, R.C.; BABATA, M.M.; BORGES, E.N. Densidade, agregação e porosidade do solo em áreas de conversão do cerrado em floresta de pinus, pastagem e Plantio direto Biosci. J., Uberlândia, v. 28, Supplement 1, 2012, p. 256-265.

WRIGHT, S.F., UPADHYAYA, A. Extraction of an abundant and unusual protein from soil and comparison with hyphal protein of arbuscular mycorrhizal fungi. Soil Science 161, 1996, p. 575-586. 


\section{CAPÍTULO 3}

\section{Compartimentos da matéria orgânica do solo sob diferentes usos da terra}

\section{RESUMO}

Considerando que inexistem estudos de avaliação do comportamento da MOS em Quilombos do Brasil, o objetivo do presente trabalho foi avaliar as frações lábeis e estáveis da matéria orgânica do solo (MOS) e os índices de labilidade (IL) e de manejo de carbono (IMC) em áreas de diferentes usos da terra no Quilombo Mesquita, em Goiás, nas profundidades de 0-10 e 10-20 cm. As áreas estudadas foram no Cerradão: Cerradão; Pastagem de braquiárias; Plantio convencional de grãos1; Tangerina com consórcio; e no Cerrado sensu stricto: Cerrado sensu stricto; Pastagem de plantas nativas e braquiárias; Plantio convencional de grãos2; Tangerina sem consórcio. Foram determinados o carbono orgânico total, as frações das substâncias húmicas e o carbono lábil, o índice de labilidade e o índice de manejo do carbono. O uso da terra (tangerina com consórcio), pautado em sistema conservacionista, foi o que apresentou os maiores acúmulos de carbono nas diferentes frações da matéria orgânica e os maiores índices de labilidade e de manejo de carbono. A fitofisionomia cerradão apresentou os maiores valores de carbono orgânico do solo e das frações das substâncias húmicas da matéria orgânica do solo. De maneira geral, as áreas nativas (Cerradão e Cerrado sensu stricto) apresentaram baixos teores de carbono lábil.

Palavras-chave: carbono lábil, substâncias húmicas, índice de manejo de carbono 


\title{
Soil organic matter pools under different land uses
}

\begin{abstract}
Whereas there are no studies evaluating MOS behavior in quilombos in Brazil, the objective of this study was to evaluate the labile and stable fractions of soil organic matter (SOM) and the lability index (IL) and carbon management (IMC) in areas of different land uses in the Quilombo Mesquita in Goiás, in the depths of 0-10 and 10-20 cm. The areas studied were in Cerradão: Cerradão; Brachiaria pasture; Conventional planting grãos1; Tangerine with the consortium; and the Cerrado sensu stricto: Cerrado sensu stricto: Pasture of native plants and Brachiaria; Conventional planting grain2; Tangerine without consortium. It was determined the total organic carbon fractions of humic substances and labile carbon, lability index and carbon management index. The land use (tangerine with consortium), based on conservation system, showed the highest carbon accumulations in the different fractions of organic matter and the highest rates of lability and carbon management. The physiognomy had the highest organic carbon values of soil and fractions of humic substances of soil organic matter. In general, the native areas (Cerradão and sensu Cerrado) had low labile carbon content.
\end{abstract}

Keywords: latosols, humic substances, lability and management index 


\subsection{INTRODUÇÃO}

As comunidades quilombolas são grupos étnicos formados por agricultores de base familiar, pluriativos, multifuncionais, tendo o local onde vivem como unidade de produção, consumo e reprodução social (Ribeiro, 2014). Essas comunidades não possuem terra suficiente e tampouco assistência técnica adequada. $\mathrm{O}$ grande desafio da atualidade é garantir a segurança alimentar dos Quilombos do Brasil, com alimentos saudáveis sem comprometer o meio ambiente e as gerações futuras. Diante dessa realidade, é necessário difundir aos agricultores que um dos fatores-chave para se atingir a sustentabilidade de um sistema de produção é a manutenção da qualidade do solo (Loss et al., 2009).

Gerenciar adequadamente um ambiente agrícola e mantê-lo produtivo é um desafio que depende da compreensão da dinâmica da matéria orgânica do solo (MOS), que influencia os atributos físicos, químicos e biológicos, com reflexo direto na estabilidade e produtividade dos agroecossistemas (Costa et al., 2013).

Uma das formas de avaliação da qualidade da MOS tem sido a quantificação do teor de carbono em suas frações estáveis e lábeis. Nesse sentindo, diversos autores (Figueiredo et al., 2010; Fontana et al., 2011; Carmo et al., 2012; Costa et al., 2013; Gazolla et al., 2015) têm demonstrado os benefícios de sistemas conservacionistas como o plantio direto, a integração lavoura-pecuária e a agricultura orgânica na redução das perdas das frações da MOS e na melhoria da qualidade do solo.

Considerando que inexistem estudos de avaliação do comportamento da MOS em Quilombos do Brasil, o objetivo do presente trabalho foi avaliar as frações lábeis e estáveis da matéria orgânica do solo (MOS) e os índices de labilidade (IL) e de manejo de carbono (IMC) em áreas de diferentes usos da terra no Quilombo Mesquita, em Goiás. 


\subsection{MATERIAL E MÉTODOS}

Dados gerais do Quilombo Mesquita, especialmente suas informações de localização, clima, seleção das áreas, histórico dos usos da terra, caracterização física e química dos Latossolos estudados, bem como o desenho amostral e a forma de coleta encontram-se no Capítulo 2.

Vale salientar que as amostras de solo, estudadas nesse Capítulo, foram as mesmas coletadas no Capitulo 2, ou seja, aquelas pertencentes as profundidades de 0-10 e $10-20 \mathrm{~cm}$.

O COT foi obtido por oxidação da matéria orgânica com dicromato de potássio, na presença de ácido sulfúrico e titulado com sulfato ferroso amoniacal, sem fonte externa de calor (Walkley \& Black, 1934), conforme relatado no Capítulo 2. No entanto, neste Capítulo, os dados de COT serão usados apenas como referência para comparação com as demais frações das substâncias húmicas, bem como serão utilizados para o cálculo do carbono não lábil (CNL), dos índices de labilidade (IL) e de manejo de carbono (IMC). Ademais, tendo em vista que os dados de COT já foram devidamente discutidos no Capítulo anterior, os valores de COT não serão discutidos no presente Capítulo.

O fracionamento das substâncias húmicas (ácido fúlvico, ácido húmico e humina) foi realizado de acordo com a metodologia descrita por Mendonça \& Matos (2005), utilizando-se como extrator uma solução de $0,1 \mathrm{~mol} \mathrm{~L}^{-1} \mathrm{NaOH}$ (relação 1:20). O ácido fúlvico (CAF) foi obtido pela porção solúvel da extração alcalina; o ácido húmico $(\mathrm{CAH})$ foi obtido após precipitação do extrato em meio ácido, e a humina (Hum) foi considerada a fração insolúvel em meio ácido ou alcalino. Após a extração, o carbono das substâncias húmicas foi quantificado por oxidação com dicromato de potássio (Nelson \& Sommers, 1982). Foram calculadas as relações entre os teores de C das frações ácido húmico e ácido fúlvico (CAH/CAF) e a relação entre as frações solúveis 
de $\mathrm{C}$ do extrato alcalino e o teor de $\mathrm{C}$ na fração humina (EA/Hum), sendo que EA (C do extrato alcalino) é obtido da seguinte forma $\mathrm{EA}=\mathrm{CAF}+\mathrm{CAH}$.

O teor de CL foi determinado pela oxidação simples com $0,033 \mathrm{~mol} \mathrm{~L}^{-1}$ de permanganato de potássio e a leitura do extrato foi feita em espectrofotômetro a $565 \mathrm{~nm}$ (Mendonça \& Matos, 2005). O carbono não lábil (CNL) foi determinado pela diferença entre o COT e o CL.

Com base nas mudanças no COT, entre um sistema de referência (vegetações nativas, CN1 e CN2) e um sistema cultivado, foi calculado o índice de compartimento de carbono (ICC), da seguinte forma: ICC = COT cultivado/COT referência. Com base nas mudanças na proporção de CL (labilidade = CL/CNL) no solo, calculou-se o índice de labilidade (IL) por IL = L cultivado/L referência. Estes dois índices foram usados para calcular o índice de manejo de carbono (IMC), obtido pela expressão IMC $=$ ICC $\times$ IL $\times 100$ (Blair et al., 1995).

A análise estatística univariada foi realizada utilizando-se o software estatístico SAS versão 9.1 (SAS, 2008) e constituiu de análise de variância (ANOVA) em relação aos dados obtidos em cada manejo sob cerradão ou cerrado sensu stricto, repetições (5), profundidades $(0-10$ e 10-20 cm) e interação tratamento*profundidade, seguida de teste de média Tukey, ao nível de 5\% de probabilidade, conforme a sensibilidade do método para carbono orgânico total (COT) e em substancias húmicas (CAF, CAH e Hum), carbono lábil (CL) e não lábil (CNL), e as relações CAH/CAF e EA/Hum. Quando a ANOVA não foi considerada significativa em relação a interação tratamento*profundidade, o teste de Tukey foi realizado a partir das médias dos atributos avaliados em cada uma das áreas amostrais. Ademais, os dados de todas as variáveis foram submetidos conjuntamente à análise de componentes principais, utilizando-se o software estatístico XLSTAT 2011. 


\subsection{RESULTADOS E DISCUSSÃO}

\subsubsection{Carbono orgânico total e em substâncias húmicas}

Para a maioria dos usos da terra estudados em ambas as fitofisionoamias, os valores de COT, Hum, CAF e CAH foram maiores na profundidade de $0-10 \mathrm{~cm}$, havendo diferenças estatísticas significantes nos valores de interação entre tratamento e profundidade (Figuras 24 e 25).
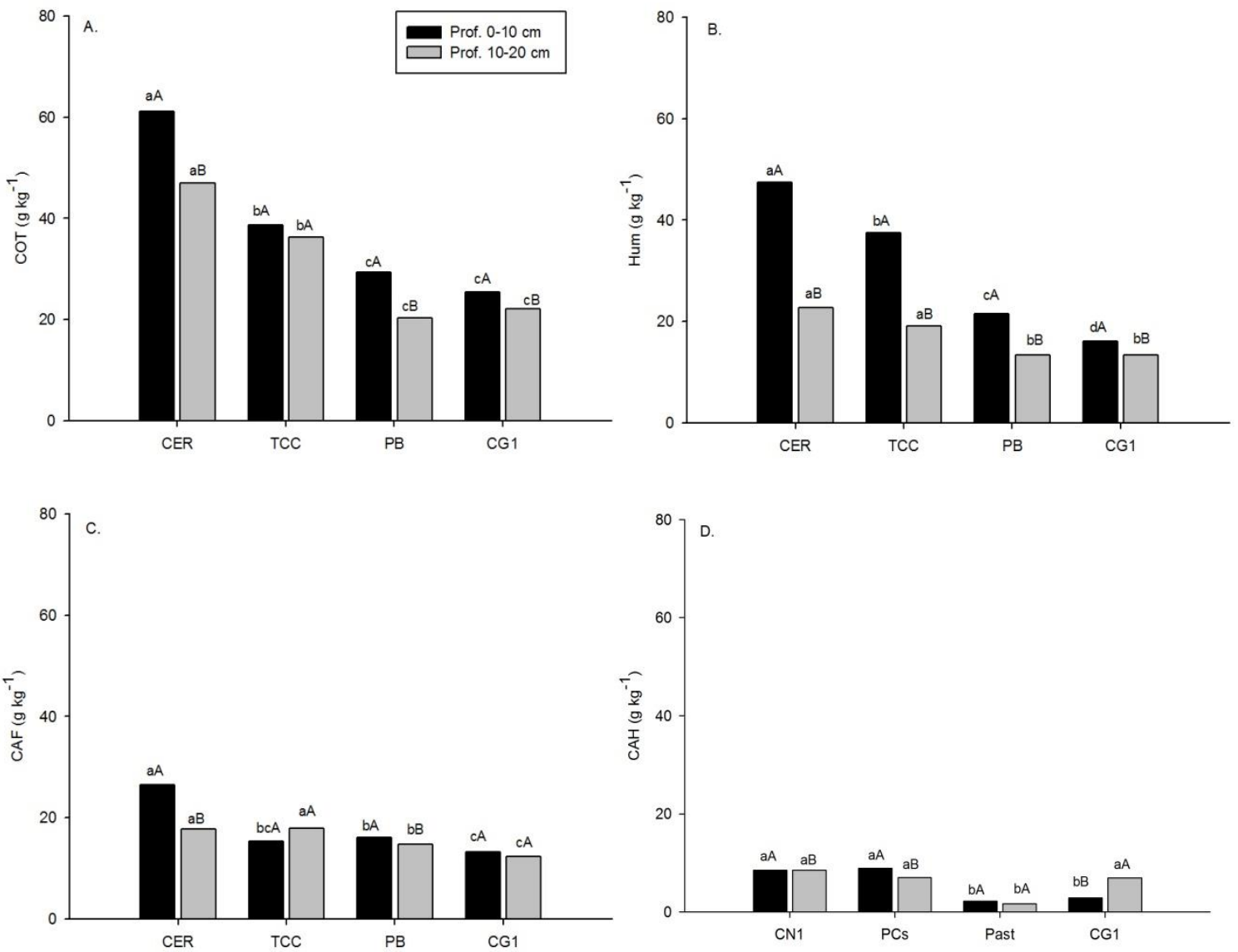

Figura 24. Teores de carbono orgânico total (COT) e de carbono nas frações humina (Hum), ácido fúlvico (CAF) e húmico $(\mathrm{CAH})$ nas profundidades de 0-10 e 10-20 cm. Nos manejos: CER: cerradão; TCC: tangerina com consórcio; PB: pastagem de braquiárias e CG1: plantio convencional de grãos. Médias seguidas de mesma letra minúscula comparam os usos em cada profundidade entre si, e maiúscula, comparam as profundidades para cada uso (Tukey; $p<0,05$ ). 

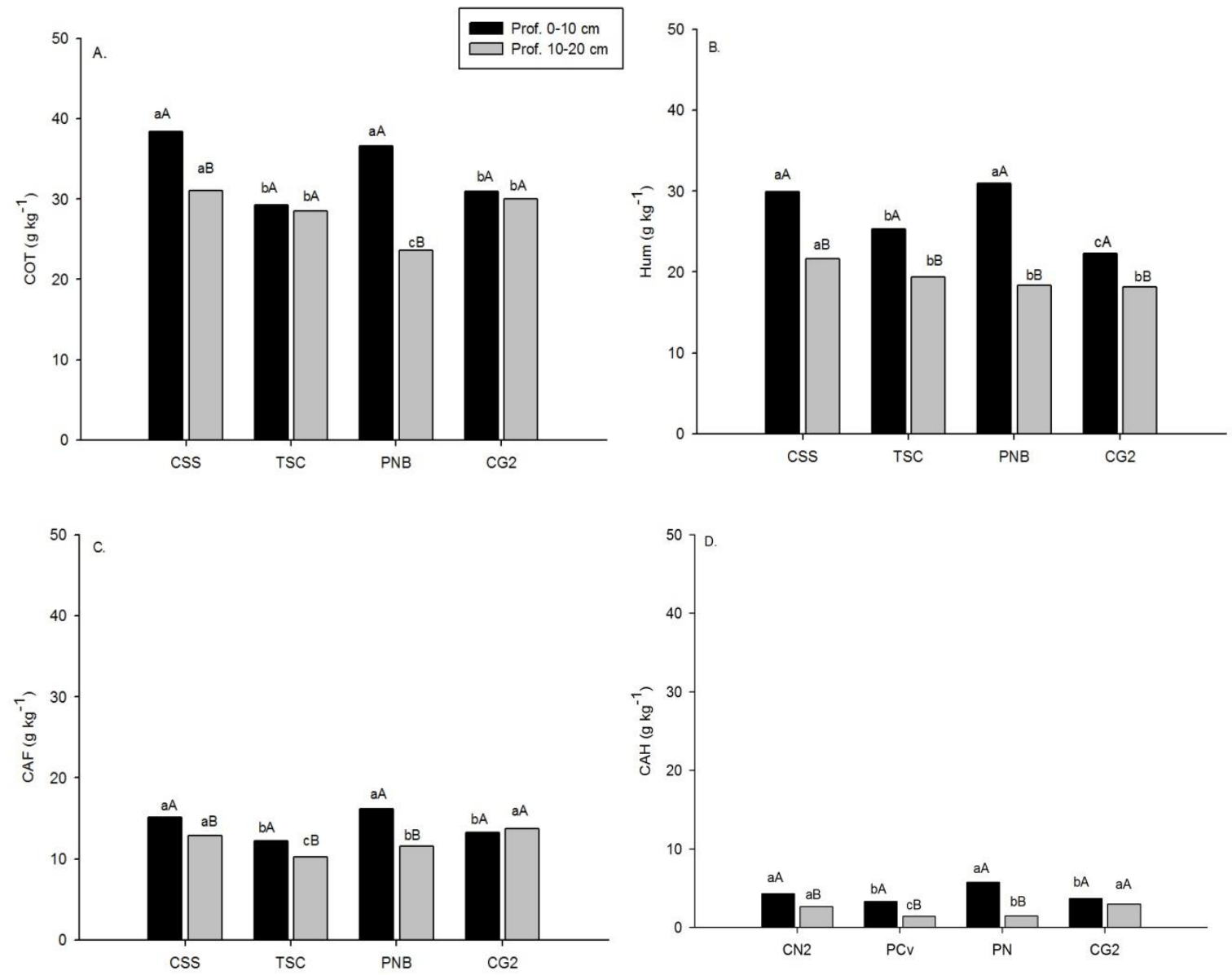

Figura 25. Teores de carbono orgânico total (COT) e de carbono nas frações humina (Hum), ácido fúlvico (CAF) e húmico (CAH) nas profundidades de 0-10 e 10-20 cm. Nos manejos: CSS: cerrado sensu stricto; TSC: tangerina sem consórcio; PNB: pastagem de plantas nativas e braquiárias e CG2: plantio convencional de grãos. Médias seguidas de mesma letra minúscula comparam os usos em cada profundidade entre si, e maiúscula, comparam as profundidades para cada uso (Tukey; $\mathrm{p}<0,05$ ).

De acordo com as Figuras 24B a 25D e 24B a 25D, observa-se que houve predominância da humina (Hum), em comparação às frações ácidos húmicos $(\mathrm{AH}) \mathrm{e}$ fúlvicos (AF), independentemente dos sistemas de manejo e profundidades analisadas. Para Dick et al. (2005), os maiores teores de C na Hum em comparação com as demais frações da MOS são observados em solos tropicais. Esse resultado é atribuído tanto à hidrofobicidade como à forte interação organo-mineral dessa fração. Ainda em termos 
de seqüestro de carbono, a humina deve ser considerada a fração mais significativa como reserva de carbono orgânico no solo (Ferreira et al., 2004).

Nas áreas manejadas sob Cerradão, na profundidade de 0-10 cm, o CER $\left(47,4 \mathrm{~g} \mathrm{~kg}^{-1}\right)$ apresentou valor de humina (Hum) significativamente maior que os demais usos da terra. Nessa profundidade, os usos da terra se comportaram da seguinte forma: $\mathrm{CER}>\mathrm{TCC}>\mathrm{PB}>\mathrm{CG} 1$, ou seja, os manejos convencionais continuaram a apresentar os menores valores de C (Figura 24B). Com relação à profundidade de 10-20 cm, verificase que os manejos CER e TCC apresentaram semelhantes e maiores que os manejos PB e CG1, que foram significativamente semelhantes.

$\mathrm{Na}$ área sob Cerrado sensu stricto, verifica-se na profundidade de 0-10 cm, que os manejos CSS e PNB apresentaram valores semelhantes de Hum, em torno de $30,46 \mathrm{~g} \mathrm{~kg}^{-1}$. Os menores valores foram em TSC e CG2, sendo o menor valor encontrado no manejo CG2. Ademais, em todos os manejos o valor de Hum foi maior na profundidade de 0-10 cm. Na profundidade de 10-20 cm, verifica-se que o CSS foi significativamente maior que os demais manejos.

Os maiores valores de Hum encontrados no CER deve-se ao menor grau de perturbação da área, comparado com os demais usos da terra, o que promove uma maior polimerização de compostos húmicos. Essa diferenciação dos valores de Hum com o tipo de uso da terra implementado também foi verificada nos estudos feitos por Rossi et al. (2012), Guareshi et al. (2013) e Sousa et al. (2015). De maneira semelhante, os maiores valores de Hum das áreas nativas sob Cerrado sensu stricto (CSS e PNB) também ocorreu devido a menor perturbação nessas áreas.

De acordo com as Figuras 24C, 24D, 25C e 25D, percebe-se que os teores de $\mathrm{CAF}$ foram maiores que o de $\mathrm{CAH}$. No manejo sob Cerradão, na Figura $24 \mathrm{C}$, na profundidade $0-10 \mathrm{~cm}$, houve diferenças entre os manejos, tendo o CER apresentado os maiores valores de $\mathrm{CAF}$, enquanto que os demais usos da terra apresentaram valores 
semelhantes. Na profundidade de 10-20 cm, o CAF se comportou da seguinte forma $\mathrm{CER}=\mathrm{TCC}>\mathrm{PB}>\mathrm{CG} 1$ Observa-se que, o CAF foi maior na profundidade de $0-10 \mathrm{~cm}$ no manejo CER, enquanto que no manejo CG1 o valor do CAF foi significativamente igual nas duas profundidades. Na Figura 25D, verifica-se na profundidade de 0-10 cm que os manejos CER e TCC foram significativamente semelhantes, com maiores valores, enquanto que a PB e CG1 foram também semelhantes e apresentaram valores menores. Nos manejos CER e TCC o teor de CAH foi maior na profundidade de 0-10 $\mathrm{cm}$, e no Past o CAH foi semelhante entre as profundidades. No sistema CG1 o CAH foi maior na profundidade de $10-20 \mathrm{~cm}$.

No manejo sob Cerrado sensu stricto, na Figura 25D, na profundidade 0-10 cm, os manejos CSS e PNB apresentaram valores semelhantes de CAH, com maiores valores, enquanto que TSC e CG2 apresentaram valores menores e significativamente semelhantes. Na comparação entre os manejos, o CSS e o PNB apresentaram os maiores valores de $\mathrm{CAF}$, enquanto que os demais manejos apresentaram valores semelhantes. Com exceção do manejo CG2, os demais manejos apresentaram valores de CAH maiores na profundidade de $10-20 \mathrm{~cm}$.

Ebeling et al. (2011), estudando a distribuição de C nas frações húmicas da MOS de um Latossolo, verificaram que o CAF foi maior que o $\mathrm{CAH}$, indicando a existência de uma evolução limitada da matéria orgânica adicionada, devido ao manejo ou por processos pedogenéticos ou ainda por aporte recente de matéria orgânica, favorecendo a formação de CAF em relação a CAH.

No presente estudo a relação $\mathrm{CAH} / \mathrm{CAF}$ foi menor que 1 , em todos os sistemas de manejo, sendo os maiores valores encontrados na camada de 0-10 cm (Tabela 24). A redução da relação $\mathrm{CAH} / \mathrm{CAF}$ da camada de $0-10 \mathrm{~cm}$ para $10-20 \mathrm{~cm}$ reflete a característica de maior solubilidade e mobilidade da CAF através do solo, distribuindo-se pelo perfil do solo, sendo considerado o principal fluxo de carbono no 
sistema. Igualmente, na profundidade de $0-10 \mathrm{~cm}$, a relação $\mathrm{CAH} / \mathrm{CAF}$ na vegetação nativa (CER) foi de 0,32, aumentando com o manejo conservacionista do solo (PCs) para 0,58 e diminuindo nas áreas com manejo convencional do solo (p.ex. Past, com relação de 0,13). Com relação às áreas manejadas no Cerrado sensu stricto, o maior valor foi no manejo PN, na camada superficial, os demais valores apresentaram o menor valor, sendo ainda semelhantes significativamente. Na profundidade de $10-20 \mathrm{~cm}$, os manejos apresentaram valores de $\mathrm{CAH} / \mathrm{CAF}$ semelhantes.

Tabela 24. Relações entre os teores de $\mathrm{C}$ das frações ácido húmico e ácido fúlvico (CAH/CAF) e entre $\mathrm{C}$ das frações solúveis do extrato alcalino e o teor de C na fração humina (EA/Hum), nas profundidades de 0-10 e 10-20 cm, em diferentes tipos de uso do solo.

\begin{tabular}{|c|c|c|c|c|c|}
\hline \multirow[t]{2}{*}{ Relação } & \multirow{2}{*}{$\begin{array}{l}\text { Profundidade } \\
\text { (cm) }\end{array}$} & \multicolumn{4}{|c|}{ Usos da terra* } \\
\hline & & CER & TCC & PB & CG1 \\
\hline \multirow{2}{*}{$\mathrm{CAH} / \mathrm{CAF}$} & $0-10$ & $0,32 \mathrm{bA}$ & $0,58 \mathrm{aA}$ & $0,13 \mathrm{cA}$ & $0,22 \mathrm{cB}$ \\
\hline & $10-20$ & $0,37 \mathrm{bA}$ & $0,39 \mathrm{bB}$ & $0,12 \mathrm{cA}$ & $0,56 \mathrm{aA}$ \\
\hline \multirow{3}{*}{ EA/Hum } & $0-10$ & $0,74 \mathrm{bB}$ & $0,65 \mathrm{bB}$ & $1,15 \mathrm{aA}$ & $0,75 \mathrm{bA}$ \\
\hline & $10-20$ & $1,08 \mathrm{bA}$ & $1,33 \mathrm{abA}$ & $1,24 \mathrm{abA}$ & $1,48 \mathrm{aB}$ \\
\hline & & CSS & TSC & PNB & CG2 \\
\hline \multirow{2}{*}{$\mathrm{CAH} / \mathrm{CAF}$} & $0-10$ & $0,28 \mathrm{bA}$ & $0,27 \mathrm{bA}$ & $0,35 \mathrm{aA}$ & $0,28 \mathrm{bA}$ \\
\hline & $10-20$ & $0,21 \mathrm{aB}$ & $0,14 \mathrm{aB}$ & $0,13 \mathrm{aB}$ & $0,22 \mathrm{aB}$ \\
\hline \multirow{2}{*}{ EA/Hum } & $0-10$ & $0,65 \mathrm{abB}$ & $0,61 \mathrm{cA}$ & $0,71 \mathrm{abB}$ & $0,76 \mathrm{aB}$ \\
\hline & $10-20$ & $0,71 \mathrm{bA}$ & $0,60 \mathrm{cA}$ & $0,69 \mathrm{bcA}$ & $0,92 \mathrm{aA}$ \\
\hline
\end{tabular}

A relação CAH/CAF foi inicialmente usada por Kononova (1982) como indicador da qualidade das substâncias húmicas, para expressar o grau de evolução do processo de humificação. Em solos tropicais, normalmente, essa relação é menor que 1, devido à menor intensidade dos processos de humificação. Para Fontana et al. (2006), os baixos valores da relação CAH/CAF indicam que os sistemas de manejo adotados, ou as seqüências de culturas implantadas, podem estar favorecendo a degradação das frações mais estáveis ou desfavorecendo sua formação. 
Para a relação EA/Hum (Tabela 24), verifica-se que, com exceção do PB, nas áreas manejadas sob cerradão, os valores dessa relação foram maiores na profundidade de $10-20 \mathrm{~cm}$, cujo valor foi maior que 1 . Na profundidade de $0-10 \mathrm{~cm}$, somente o Past apresentou relação maior que 1. Nas áreas manejadas no cerrado sensu stricto, verifica-se que os manejos CSS, PNB e CG2, o teor dessa relação foi menor na camada superficial. Ademais em todas as profundidades, o EA/Hum foi menor que 1. Para Fontana et al.(2006), de maneira geral, valores de EA/Hum menores que 1 indicam um elevado grau de humificação da matéria orgânica nos solos estudados, havendo predomínio da Hum (fração mais estável) sobre as demais frações (CAF e CAH)

\subsubsection{Efeito dos sistemas de uso do solo na labilidade da matéria orgânica}

Nas Figuras 26 e 27, encontram-se os valores de CL, CNL e os índices de labilidade e manejo de $\mathrm{C}$, os quais variaram de acordo com o tipo de manejo e profundidade estudados, havendo diferenças significativas entre a interação profundidade e tratamento.

Nas áreas manejadas sob Cerradão, verifica-se que o maior teor de CL foi

no TCC $\left(2,61 \mathrm{~g} \mathrm{~kg}^{-1}\right)$ (Figura 26A). Com relação aos demais usos, estes apresentaram valores semelhantes de CL. Ademais, de maneira geral, os teores de CL foram significativamente maiores na camada mais superficial do solo $(0-10 \mathrm{~cm})$. Silva et al. (2011) e Leite et al. (2013) indicam que sistemas conservacionistas favorecem a manutenção dos resíduos culturais na superfície do solo o que proporciona de composição lenta do material vegetal depositado favorecendo o acúmulo de CL.

Nas áreas manejadas sob Cerrado sensu stricto, verifica-se que na profundidade de 0-10 cm, o maior teor de CL foi no PNB, seguido do TSC (Figura 27A). Os demais manejos apresentaram valores significativamente semelhantes e menores. Na profundidade de 10-20 cm, o PNB continuou com maior o valor, seguido 
do CSS. Ademais, o CL foi maior na profundidade de 0-10 $\mathrm{cm}$ para todos os manejos estudados.

Percebe-se que nas áreas nativas (CER e CSS), Figuras 26A e 27A, o valor médio de CL foi de $1,7 \mathrm{~g} \mathrm{~kg}^{-1}$, sendo valores menores, comparados aos sistemas TCCs, PNB, TSC, mas superiores ao Past, CG1 e CG2. Esse comportamento revela que, possivelmente, o CL nas áreas nativas foi rapidamente mineralizado a compostos orgânicos de maior estabilidade química e alto peso molecular.
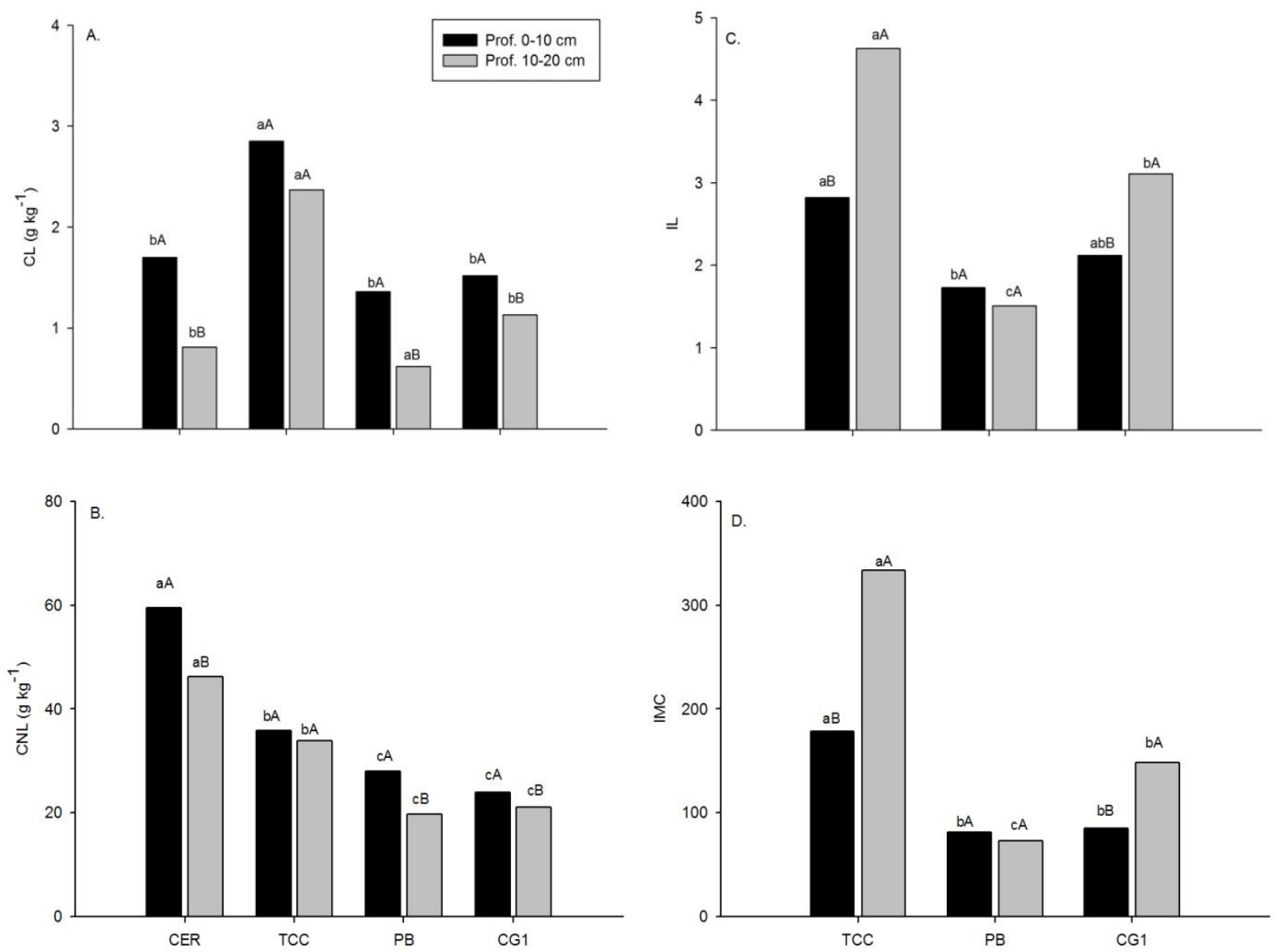

Figura 26. Teores de carbono lábil (CL) e não lábil (CNL), índices de labilidade (IL) e de manejo do carbono (IMC), nas profundidades de 0-10 e 10-20 cm. Nos manejos: CER: cerradão; TCC: tangerina com consórcio; PB: pastagem de braquiárias e CG1: plantio convencional de grãos. Médias seguidas de mesma letra minúscula comparam os usos em cada profundidade entre si, e maiúscula, comparam as profundidades para cada uso (Tukey; $p<0,05$ ). 
O menor acúmulo de CL nas áreas nativas e parte das áreas cultivadas pode ser decorrente da composição química da cobertura vegetal, com predominância de compostos de carbono mais recalcitrantes. É provável que a menor proporção do carbono na forma lábil, explique o maior estoque de COT em áreas sob vegetação natural no Bioma Cerrado.
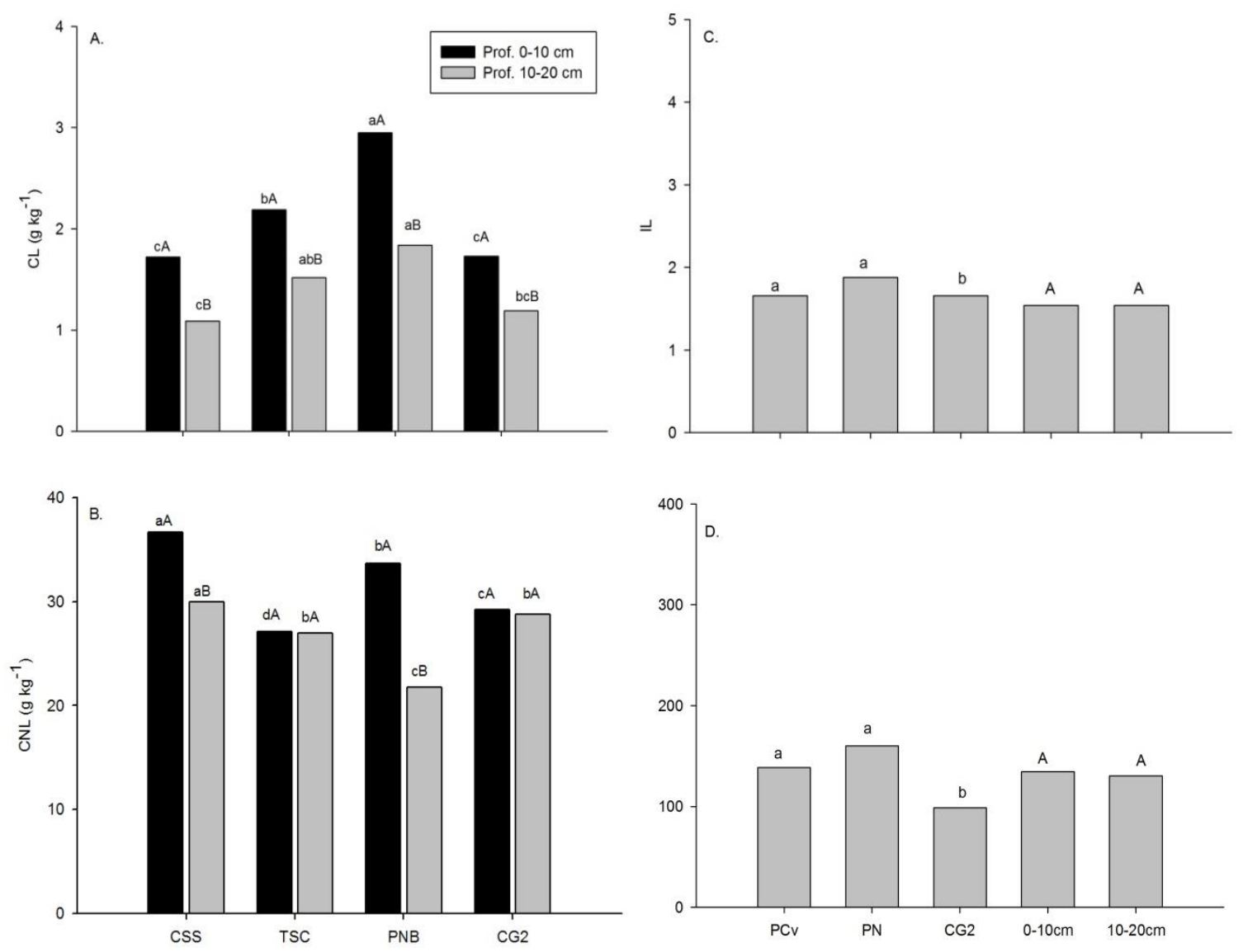

Figura 27. Teores de carbono lábil (CL) e não lábil (CNL), índices de labilidade (IL) e de manejo do carbono (IMC), nas profundidades de 0-10 e 10-20 cm. Nos manejos: CSS: cerrado sensu stricto; TSC: tangerina sem consórcio; PNB: pastagem de plantas nativas e braquiárias e CG2: plantio convencional de grãos. Médias seguidas de mesma letra minúscula comparam os usos em cada profundidade entre si, e maiúscula, comparam as profundidades para cada uso (Tukey; $\mathrm{p}<0,05$ ).

Em todos os sistemas de uso e manejo do solo houve a predominância do carbono não lábil (CNL) em relação ao CL (Figura 26A, 26B, 27A e 27B). Todavia, só 
houve interação significativa com o CNL das áreas sob cerradão, tendo sido verificado que, em ambas as profundidades, o valor de CNL foi maior no CER e os demais manejos tiveram o seguinte comportamento TCC >PB=CG1 (Figura 26B). Com exceção do PCs, os demais manejos apresentaram valores de CNL significativamente maiores na profundidade de 0-10 cm. Quanto o CNL na área Cerrado sensu stricto, não houve interação significativa, tendo sido evidenciado que o TSC obteve o maior valor e os demais manejos foram semelhantes, apresentando os menores valores (Figura 27B). Ademais, o CNL foi maior significativamente na profundidade de $0-10 \mathrm{~cm}$.

Quanto ao índice de labilidade, verifica-se que nas áreas manejadas no Cerradão sob TCC e CG1, o IL na profundidade de 10-20 foi maior que na de 0-10 cm. (Figura 26C). No manejo Past, o IL foi igual nas duas profundidades. Ademais na profundidade de $0-10 \mathrm{~cm}$, o maior valor de IL foi no TCC e o menor foi no PB, ficando o CG1 com valor de IL semelhante ao TCC e PB. Todavia na profundidade de 10-20 cm, verifica-se que o IL teve o seguinte comportamento: TCCs>CG1>PB. Nas áreas manejadas no Cerrado sensu stricto, não houve interação significativa, sendo o maior valor de IL encontrado na PNB e TSC, enquanto o CG2 apresentou o menor valor. Ademais, e não houve diferenças entre as profundidades (Figura 27C).

Com relação ao IMC, verifica-se que houve diferença significativa entre os manejos e profundidades apenas nas áreas sob cerradão (Figura 26D e 27D). Tendo o CER, como área nativa de referência, observa-se que na profundidade de $0-10 \mathrm{~cm}$, apenas o manejo TCC apresentou IMC maior que 100 (178), sendo esse valor significativamente maior entre os manejos estudados. Já o PB e o CG1 apresentaram valores semelhantes de IMC de 81 e 86, respectivamente. Com relação às profundidades, verifica-se que no TCC e no CG1 o IMC foi significativamente maior na profundidade de 10-20 cm, não havendo diferenciação no PB, entre as profundidades. Adotando-se o CSS como área de referência, verificou-se que apenas o manejo CG2 
apresentou IMC menor que 100 (93), ficando os manejos TSC e PNB com IMC de 132 e 167, respectivamente (Figura 27D), sendo esses valores significativamente semelhantes. Ademais, não houve diferenças entre as profundidades. Vale constar que, sistemas de manejo do solo com valores de IMC acima de $100 \%$ indicam que nesses sistemas o manejo adotado elevou a qualidade do solo, indicando prática favorável à manutenção da MOS. Esses resultados corroboram aqueles observados por Schiavo et al. (2011) e Rossi et al. (2012).

\subsubsection{Análise de componentes principais}

Os resultados dos compartimentos da MOS, referentes aos diferentes usos da terra estudados, foram ordenados por meio da ACP (Figuras 28 e 29), para as profundidades de 0-10 cm (Figura 28) e 10-20 cm (Figura 29).

A distribuição das variáveis analisadas mostrou variância acumulada de $79,47 \%$ e $67,05 \%$ para os componentes principais nas profundidades de $0-10 \mathrm{~cm}$ e 10 $20 \mathrm{~cm}$, respectivamente (Figuras 28 e 29). Na profundidade de 0-10 cm, o eixo CP1 separou quatro grupos: CER; PNB/TCC; CSS; e PB/CG1/CG2/TSC (Figura 28).

Com base nos resultados apresentados separadamente para cada atributo, a área nativa (CER) foi a área com a melhor qualidade da MOS, sendo tal fato explicado pelos elevados valores de COT e das substâncias húmicas. Verificou-se que nessa área nativa, apesar do solo ser distrófico, com saturação por bases de $42 \%$ e baixa saturação por Al trocável (8\%), existe uma fertilidade natural diferenciada nesse local. Isso justifica o fato dessas áreas serem as mais utilizadas pelos quilombolas para as atividades agrícolas. De acordo com a Figura 28, as variáveis que mais explicam a melhor qualidade da MOS do CER são as frações COT, CAH, CAF, Humina e CNL. 


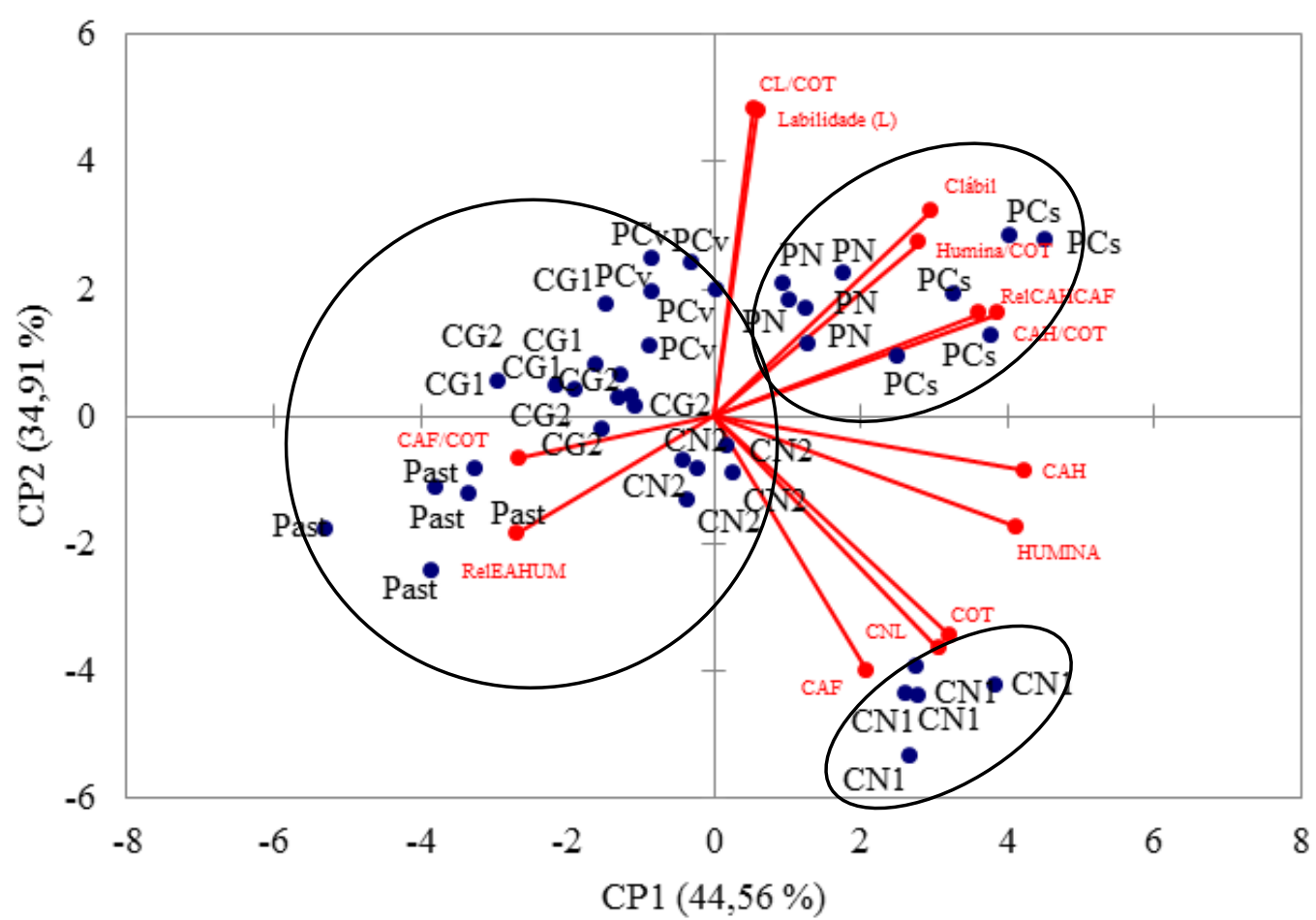

Figura 28. Análise de componentes principais dos compartimentos estáveis e mineralizáveis da MOS nas profundidades de 0-10 e 10-20 cm, quando submetido a diferentes usos/manejos por agricultores quilombolas. CER: cerradão; TCC: tangerina com consórcio; PB: pastagem degradada; CG1: plantio convencional de grãos; CSS: Cerrado sensu stricto; TSC: tangerina sem consórcio; PNB: pastagem natural; CG2: plantio convencional de grãos.

A baixa fertilidade natural do cerrado sensu stricto (CSS) fez com que a qualidade da MOS desse sistema fosse semelhante aos sistemas de manejo convencional do solo (CG1, CG2, TSC e PB). No entanto, na profundidade de $10-20 \mathrm{~cm}$, a qualidade da MOS do CSS foi semelhante ao TCC (Figura 29). O sistema Past foi o que apresentou a menor qualidade da MOS, considerando os usos do solo e as variáveis estudadas. 


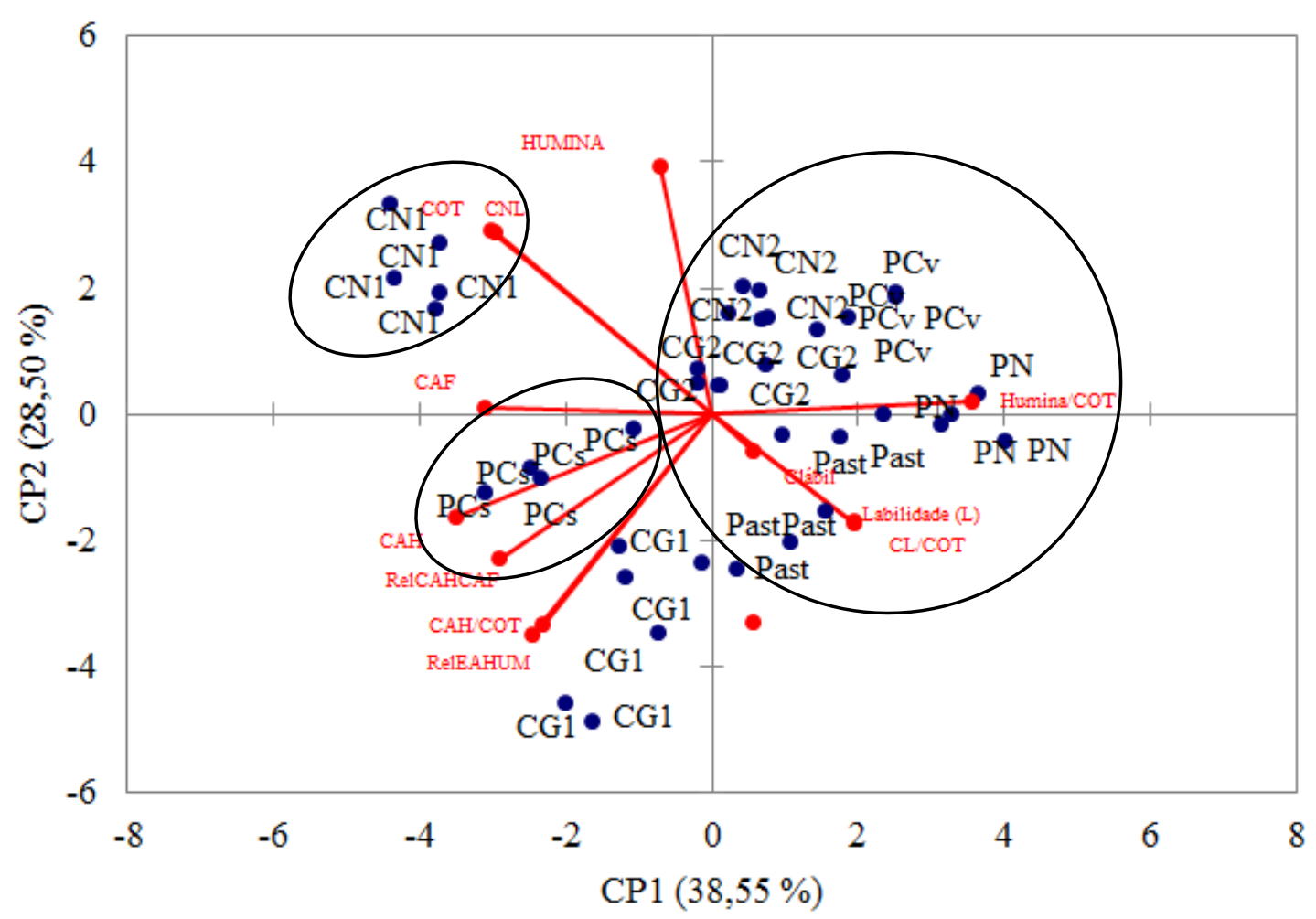

Figura 29. Análise de componentes principais dos compartimentos estáveis e mineralizáveis da MOS nas profundidades de 0-10 e 10-20 cm, quando submetido a diferentes usos/manejos por agricultores quilombolas. CER: cerradão; TCC: tangerina com consórcio; PB: pastagem degradada; CG1: plantio convencional de grãos; CSS: Cerrado sensu stricto; TSC: tangerina sem consórcio; PNB: pastagem natural; CG2: plantio convencional de grãos. Médias seguidas de mesma letra minúscula comparam os manejos em cada profundidade entre si, e maiúscula, comparam as profundidades para cada manejo (Tukey; $\mathrm{p}<0,05$ ).

Ficou evidente que ao se manejar agricolamente uma área nativa, como foi o caso do cerradão (CER), há perdas de carbono nas frações estáveis e lábeis, porém ao se utilizar um sistema de cultivo conservacionista, como foi caso do TCC, essas perdas podem ser reduzidas. Ademais, a qualidade da MOS no manejo adotado no TCC foi semelhante à da pastagem natural (PNB), sendo esse comportamento explicado pela labilidade, CL e pela relação CAH/CAF. 
Os resultados obtidos no presente trabalho demonstram que os agricultores quilombolas necessitam intensificar os sistemas de manejo sustentável do solo, com uso rigoroso de práticas conservacionistas (plantio direto, adubação orgânica, etc.), que permitam preservar a MOS e as reservas de nutrientes. No entanto, a existência de poucas tecnologias apropriadas à realidade desses agricultores tem levado ao uso de práticas ecológicas e tecnicamente incorretas que estão ocasionando o empobrecimento dos solos, a redução da produtividade e a descapitalização dos produtores.

\subsection{CONCLUSÕES}

1. O uso da terra (tangerina com consórcio), pautado em sistema conservacionista, foi o que apresentou os maiores acúmulos de carbono nas diferentes frações da matéria orgânica e os maiores índices de labilidade e de manejo de carbono.

2. A fitofisionomia cerradão apresentou os maiores valores de carbono orgânico do solo e das frações das substâncias húmicas da matéria orgânica do solo.

3. De maneira geral, as áreas nativas (Cerradão e Cerrado sensu stricto) apresentaram baixos teores de carbono lábil.

\subsection{REFERÊNCIAS BIBLIOGRÁFICAS}

BLAIR, G. J.; LEFROY, R. D. B.; LISLE, L. Soil carbon fractions based on their degree of oxidation, and the development of a carbono management index for agricultural systems. Australian Journal of Agricultural Research, v.46, p.1459-1466, 1995.

BUSTAMANTE, M. M. C.; CORBEELS, M.; SCOPEL, E.; ROSCOE, R. Soil carbon and sequestration potential in the Cerrado Region of Brazil. In: Lal R, Cerri C. C, Bernoux, M., Etchevers, J., Cerri CEP (Eds) Carbon sequestration in soils of Latin America. 1. ed. New York: Food Product Press, 2006. Cap. 14, p. 285-304. 
CARMO, F. F.; FIGUEIREDO, C. C.; RAMOS, M. L. G.; VIVALDI, L. J.; ARAÚJO, L. G. Frações granulométricas da matéria orgânica em latossolo sob plantio direto com gramíneas. Bioscience Journal, v. 28, n. 3, p. 420-431, 2012.

COSTA, A. R.; SATO, J. H.; RAMOS, M. L. G.; FIGUEIREDO, C. C. SOUZA, J. P. ROCHA, O. C.; GUERRA, A. F. Microbiological properties and oxidizable organic carbon fractions of an Oxisol under coffee with split phosphorus applications and irrigation regimes. Revista Brasileira de Ciência do Solo, v.37, p.55-65, 2013.

DICK, D. P.; GONÇALVES, C. N.; DALMOLIN, R. S. D.; KNICKER, H.; KLAMT, E.; KOGEL-KNABNER, I.; SIMOES, M.L.; MARTIN-NETO, L. Characteristics of soil organic matter of different Brazilian Ferralsols under native vegetation as a function of soil depth. Geoderma, v.124, p.319-333, 2005.

EMBRAPA - Empresa Brasileira de Pesquisa Agropecuária, 2016. <http://www.agritempo.gov.br/agritempo/index.jsp 27 Mar 2016.

EMBRAPA - Empresa Brasileira de Pesquisa Agropecuária. Manual de métodos de análise de solo. 2.ed. Rio de Janeiro: Centro Nacional de Pesquisa de Solos, 2011. 627 p.

EMBRAPA - Empresa Brasileira de Pesquisa Agropecuária. Sistema Brasileiro de Classificação de solos. 3. ed. Rio de Janeiro: Centro Nacional de Pesquisa de Solos, 2013. 353 p.

EBELING, A.G.; ANJOS, L.H.C.; PEREIRA, M.G.; PINHEIRO, F.M.; VALADARES, G.S. Substâncias húmicas e relação com atributos edáficos. Bragantia, Campinas, v. 70, n. 1, 2011, p.157-165.

FERREIRA, J.A.; SIMÕES, M.L.; MILORE, D.M.B.P.; MARTINNETO, L.; HAYES, M.H.B. Caracterização Espectroscópica da Matéria Orgânica do Solo. Embrapa São Carlos, 2004. (Circular Técnica, 24).

FIGUEIREDO, C. C.; RESCK, D. V. S.; CARNEIRO, M. A. C. Labile and stable fractions of soil organic matter under management systems and native cerrado. Revista Brasileira de Ciência do Solo, v. 34, p. 907-916, 2010. 
FONTANA, A.; PEREIRA, M.G.; LOSS, A.; CUNHA, T.J.F.; SALTON, J.C. Atributos de fertilidade e frações húmicas de um Latossolo Vermelho no Cerrado. Pesq. agropec. bras., Brasília, v.41, n.5, maio 2006, p.847-853,

FONTANA, A.; SILVA, C. F.; PEREIRA, M. G.; LOSS, A.; BRITO, R. J. B.; BENITES, V. M. Avaliação dos compartimentos da matéria orgânica em área de Mata Atlântica. Acta Scientiarum. Agronomy, v. 33, p. 545-550, 2011.

GAZOLlA, P. R.; GUARESCHI, R. F.; PERIN, A.; PEREIRA, M. G.; ROSSI, C. Q. Frações da matéria orgânica do solo sob pastagem, sistema plantio direto e integração lavoura-pecuária. Semina: Ciências Agrárias, v. 36, p. 693-704, 2015.

GUARESCHI, R. F. ET AL., PEREIRA, M. G., PERIN, A. Oxidizable carbon fractions in Red Latosol under different management systems. Revista Ciência Agronômica, v.44, p.242-250, 2013.

KONONOVA, M. M. Materia orgánica del suelo: su naturaleza, propiedades y métodos de investigación. Barcelona: Oikos-tau, 1982. 364 p.

LEITE, L. F. C., ARRUDA, F. P.; COSTA, C. N.; FERREIRA, J. S. F.; NETO, M. R. H. Qualidade química do solo e dinâmica de carbono sob monocultivo e consórcio de macaúba e pastagem. Revista Brasileira de Engenharia Agrícola e Ambiental, v.17, p.1257-1263, 2013.

LOSS, A.; PEREIRA, M. G.; SCHULTZ, N.; ANJOS, L. H. C. DOS; SILVA, E. M. R. Carbono e frações granulométricas da matéria orgânica do solo sob sistemas de produção orgânica. Ciência Rural, v.39, p.1067-1072, 2009.

MENDONÇA, E. S.; MATOS, E. S. Matéria orgânica do solo: Métodos de análises. Viçosa: UFV, 2005. 107p.

NELSON, D. W.; SOMMERS, L. E. Total carbon, organic carbon, and organic matter. In: PAGE, A. L.; MILLER, R. H.; KEENEY, D. R. (ed.). Methods of soil analysis chemical and microbiological properties. Part 2. 2.ed. Madison: American Society of Agronomy and Soil Science Society of America, 1982. p. 539-577.

RIBEIRO, A. S. S. Saberes tradicionais e educação ambiental: encontros e desencontros no Quilombo de Mesquita- Goiás. Brasília: UnB, 2014. 284p. Tese de doutorado. 
ROSSI, C. Q.; PEREIRA, M. G.; GIÁCOMO, S. G.; BETTA, M.; POLIDORO, J. C. Frações lábeis da matéria orgânica em sistema de cultivo com palha de braquiária e sorgo. Revista Ciência Agronômica, v. 43, p. 38-46, 2012.

RTID/INCRA - Relatório Técnico de Identificação e Delimitação do Quilombo Mesquita. INCRA: Instituto Nacional de Colonização de Reforma Agrária. Publicado no Diário Oficial da União (DOU) de 29 e 30/08/2011.

SCHIAVO, J. A.; ROSSET, J. S.; PEREIRA, M. G., SALTON, J.C. Índice de manejo de carbono e atributos químicos de Latossolo Vermelho sob diferentes sistemas de manejo. Pesquisa Agropecuária Brasileira, v.46, p.1332-1338, 2011.

SILVA, E. F.; LOURENTE, E. P. R.; MARCHETTI, M. E.; MERCANTE, F. M.; FERREIRA, A. K. T.; FUJI, G. C. Frações lábeis e recalcitrantes da matéria orgânica em solos sob integração lavoura-pecuária. Pesquisa Agropecuária Brasileira, Brasília, v. 46, p. 1321-1331, 2011.

SOUSA, R. F.; BRASIL, E. P. F.; FIGUEIREDO, C. C.; LEANDRO, W. M. Soil organic matter fractions in preserved and disturbed wetlands of the cerrado biome. Revista Brasileira de Ciência do Solo, v.39, p. 222-231, 2015.

WALKLEY, A.; BLACK, I. A. An examination of the Degtjareff method for determining soil organic matter and a proposed modification of the chromic acid titration method. Soil Science, v.37, p.29- 38, 1934. 


\section{CAPÍTULO 4}

\section{Carbono e nitrogênio nas frações granulométricas de um Latossolo sob diferentes usos da terra}

\section{RESUMO}

Com o objetivo de estudar as formas de C orgânico e $\mathrm{N}$ nas frações granulométricas da matéria orgânica de um Latossolo Vermelho distrófico típico sob diferentes usos do solo, nas profundidades de 0-5, 5-10, 10-20 e 20-30 cm. Os usos da terra estudados foram no Cerradão: Cerradão; Pastagem braquiárias; Plantio convencional de grãos1; Tangerina com consórcio; e no Cerrado sensu stricto: Cerrado sensu stricto; Pastagem de plantas nativas e braquiárias; Plantio convencional de grãos2; Tangerina sem consórcio. Foram quantificados os teores de carbono orgânico total (COT), particulado (COP) e associado aos minerais (COAM), bem como o nitrogênio total (NT), particulado (NOP) e associado aos minerais (NOAM). O uso da terra com sistema conservacionista (tangerina com consórcio) foi o que menos alterou o compartimento total e as frações granulométricas de $\mathrm{C}$ e $\mathrm{N}$ da matéria orgânica do solo, em comparação com os demais usos da terra. As áreas adubadas com nitrogênio (tangerina com e sem consórcio e plantio convencional de grãos) apresentaram maior teor de $\mathrm{N}$ total, do que o Cerradão, porém essa área nativa apresentou maior NOP. O Cerradão apresentou os maiores valores de $\mathrm{C}$ total e das frações granulométricas. O Cerrado sensu stricto e a pastagem de plantas nativas e braquiárias apresentaram maior valor de COT e COAM do que os demais usos da terra, porém o valor de COP foi semelhante em todos os usos. Ademais, a pastagem de plantas nativas e braquiárias apresentou maior $\mathrm{N}$ total e nas frações granulométricas do que os demais usos da terra.

Palavras-chave: fracionamento, matéria orgânica do solo e manejo convencional e conservacionista. 


\title{
Soil organic matter in the granulometric fractions of an oxissol under different
}

\section{management systems}

\begin{abstract}
In order to study the forms of organic $\mathrm{C}$ and $\mathrm{N}$ in grain size fractions of the organic matter of an Oxisol under different typical land use at depths of 0-5, 5-10, 10-20 and 20-30 cm. The land uses were studied in Cerradão: Cerradão; Brachiaria pasture; Conventional planting grain1; Tangerine with the consortium; and the Cerrado sensu stricto: Cerrado sensu stricto; Pasture of native plants and brachiarias; Conventional planting grain2; Tangerine without consortium. The total organic carbon levels were quantified (TOC), particulate (COP) and associated minerals (COAM) and total nitrogen (TN), particulate (NOP) and associated minerals (NOAM). The land use with conservation system (tangerine with consortium) was the least changed the total compartment and the fractions of $\mathrm{C}$ and $\mathrm{N}$ in soil organic matter, in comparison with other land uses. The areas fertilized with nitrogen (tangerine with and without consortium and conventional planting grain) had higher total $\mathrm{N}$ content than Cerradão, but this native area showed higher NOP. The Cerradão had the highest overall $\mathrm{C}$ values and the size fractions. The Cerrado sensu stricto and pasture of pasture native plants and brachiarias had higher TOC and COAM than other land uses, but the COP value was similar in all uses. Moreover, the grazing of native plants and brachiarias presented a higher total $\mathrm{N}$ and the size fractions than other land uses.
\end{abstract}

Keywords: fractionation, soil organic matter and conventional and conservation management. 


\subsection{INTRODUÇÃO}

O uso de práticas agrícolas que aumentam o teor da matéria orgânica (MOS) em solos do Cerrado é fundamental, já que predominam, no País, e, no Estado de Goiás, solos ácidos altamente intemperizados, com baixa reserva de nutrientes e com presença de argilas, óxidos e sesquióxidos de $\mathrm{Fe}$ e $\mathrm{Al}$ de baixa atividade, como os Latossolos. Nessas condições, a MOS desempenha papel primordial na determinação da fertilidade do solo e produtividade das culturas, pois é nessa matriz que se encontra o maior reservatório de cargas nos solos de Cerrado (Rosco et al., 2006; Sá et al, 2008; Silva et al., 2011; Costa et al, 2013). Portanto, um solo com bom teor de MOS é imprescindível para a produção sustentável de alimentos e para atender as necessidades da população (Malhi et al., 2011; Khorramdel et al., 2013. Paul et al., 2013).

A qualidade da MOS, por sua vez, está intrinsecamente associada à distribuição das suas frações no solo (Salton et al., 2011), que consequentemente, promovem efeitos diferentes sobre as propriedades edáficas. Os sistemas de usos da terra ao aportarem diferentes quantidades de carbono no solo, alteram a labilidade da MOS, ou seja, a proporção de MOS lábil em relação à não lábil. Neste contexto pode-se utilizar como indicador da mudança de manejo do solo ou da qualidade ambiental, a distribuição das frações de matéria orgânica (Carmo et al., 2012, Rossi et al., 2012, Wink et al., 2014, Vieira et al., 2015), tendo em vista que mudança do uso da terra alteram os teores de carbono orgânico e N, a qualidade da MOS e a agregação dos solos (Bayer et al., 2004; Figueiredo et al., 2010; Salton et al., 2011; Bezerra et al., 2014; Giácomo et al., 2015).

Ademais, a baixa disponibilidade de $\mathrm{N}$, somada à grande necessidade por parte dos vegetais, faz com que ele seja um dos nutrientes mais limitantes da produtividade da maioria das culturas. Essa baixa disponibilidade é decorrente do fato 
de que $95 \%$ ou mais do $\mathrm{N}$ do solo encontra-se na forma orgânica, sendo somente uma pequena parte mineralizada durante o ano (Siqueira, 1993).

Dentre as frações da MOS comumente avaliadas, tem-se as frações físicas obtidas através do fracionamento físico granulométrico da MOS (Cambardella \& Elliott, 1992). Esse tipo de fracionamento envolve a separação da MOS em função do seu próprio tamanho ou de partículas às quais está associada. Na maioria dos solos, as frações orgânicas encontram-se mais associadas à argila e ao silte $(<53 \mu \mathrm{m})$, de forma que as quantidades de carbono e nitrogênio associadas à areia $(>53 \mu \mathrm{m})$ não perfazem mais do que 10\% (Rosell et al., 1996, Rossi et al., 2012). Apesar de contribuir somente com pequena parte da matéria orgânica presente nos solos, é a areia que se associa às frações orgânicas de maior biodisponibilidade, em relação àquelas ligadas à argila e ao silte (Christensen, 1996). Tal fato se deve ao processo de separação da areia das demais partículas texturais, na medida em que, durante a dispersão dos solos, mais especificamente na etapa de peneiramento, agrega-se à areia material orgânico particulado, com grau de decomposição mais próximo ao de resíduos vegetais recentemente adicionados aos solos, em sistemas onde ocorre o maior aporte de biomassa vegetal e animal. À argila e, com menor intensidade, ao silte, ligam-se compostos de relação $\mathrm{C}: \mathrm{N}$ baixa, normalmente resultantes do metabolismo de microrganismos (Christensen, 1996).

Segundo Figueiredo et al. (2010), Loss et al. (2012), Rossi et al. (2012) e Winck et al. (2014) em sistemas onde ocorre o maior aporte de biomassa, o acúmulo de carbono ocorre preferencialmente na matéria orgânica particulada, a qual é mais sensível, do que o carbono orgânico total às alterações no manejo do solo. A entrada e a maior concentração de MO particulada ocorrem, principalmente, nos primeiros centímetros abaixo da superfície do solo, sendo diretamente influenciadas pela serapilheira e raízes (Duxbury et al., 1989). 
Considerando a constituição variada da MOS, que inclui desde frações ativas a mais estáveis, a importância do $\mathrm{N}$ no processo produtivo e as mudanças promovidas pelas diferentes usos da terra sobre os teores de $\mathrm{C}$ orgânico e $\mathrm{N}$, foi realizado um trabalho com o objetivo de estudar as formas de $\mathrm{C}$ orgânico e $\mathrm{N}$ nas frações granulométricas da matéria orgânica de um Latossolo Vermelho distrófico típico sob diferentes usos do solo.

\subsection{MATERIAL E MÉTODOS}

Dados gerais do Quilombo Mesquita, especialmente suas informações de localização, clima, seleção das áreas, histórico dos usos da terra, caracterização física e química dos Latossolos estudados, bem como o desenho amostral e a forma de coleta encontram-se no Capítulo 2.

Vale salientar que as amostras de solo, estudadas nesse Capítulo, foram diferentes dos Capítulos anteriores. Portanto, foi realizada coleta de amostras de solo, na mesma época e, obedecendo aos mesmos critérios dos Capítulos anteriores, porém nas profundidades de $0-5,5-10,10-20$ e $20-30 \mathrm{~cm}$, com o intuito de encontrar maiores diferenças nas frações estudadas e de se obter o estoque de C e N. Assim, essas amostras foram destorroadas, secas ao ar e passadas em peneiras de $2 \mathrm{~mm}$ para a determinação do carbono orgânico total (COT), nitrogênio total (NT) e do fracionamento de C e N nas frações granulométricas da matéria orgânica do solo.

O carbono orgânico total (COT) foi obtido por oxidação da matéria orgânica, sem aquecimento externo, com dicromato de potássio, em meio sulfúrico e titulado com sulfato ferroso amoniacal, sem aquecimento e com fator de correção (Walkley \& Black, 1934). O nitrogênio total (NT) foi determinado pela metodologia de Bremner (1996), que envolve o uso de uma mistura digestora à base de $\mathrm{K}_{2} \mathrm{SO}_{4}, \mathrm{CuSO}_{4} \mathrm{e}$ Se. A cada amostra de $0,1 \mathrm{~g}$ de solo, foram adicionados $1,1 \mathrm{~g}$ da mistura digestora e 3,0 $\mathrm{mL}$ de $\mathrm{H}_{2} \mathrm{SO}_{4}$ p.a. A digestão foi feita a $350{ }^{\circ} \mathrm{C}$, e o $\mathrm{N}$ evoluído por destilação a vapor 
foi recolhido em uma solução de $\mathrm{H}_{3} \mathrm{BO}_{3}\left(20 \mathrm{~g} \mathrm{~L}^{-1}\right)$, misturada a uma solução de verde de bromocresol e vermelho de metila e titulado com solução de $\mathrm{HCl}$ 0,01 mol L-1.

O fracionamento granulométrico da MOS foi realizado segundo Cambardella e Elliott (1992). Vinte gramas de TFSA foram submetidos à agitação horizontal por 15 horas na presença de $60 \mathrm{~mL}$ de solução de hexametafosfato de sódio na concentração de $5 \mathrm{~g} \mathrm{~L}^{-1}$. Em seguida, a suspensão foi passada em peneira de $53 \mu \mathrm{m}$ com o auxílio de jato de água. O material retido na peneira, que consiste no carbono orgânico particulado (COP) e nitrogênio particulado (NOP) associado à fração areia, foi seco em estufa a $60^{\circ} \mathrm{C}$, moído, pesado e analisados. O COP e o NOP foram quantificados conforme descrito para o COT e NT. O material que passou pela peneira de $53 \mu \mathrm{m}$, que consiste no carbono e no nitrogênio associado aos minerais (COAM e NOAM, respectivamente) das frações silte e argila, foi obtido por diferença entre o COT e COP e NT e NOP. Foram calculadas as relações COP/COT, COAM/COT, NOP/NT e NOAM/NT.

Para avaliar os impactos do uso do solo foram determinados os estoques de carbono de COT, COP e COAM e de nitrogênio de NT, NOP e NOAM. Com os valores de estoque de $\mathrm{C}$ e $\mathrm{N}$ correspondente à camada de $0-30 \mathrm{~cm}$, em $\mathrm{Mg} \mathrm{ha}^{-1}$, obtido pelo método da camada equivalente (Bayer et al., 2000), foi calculado o Delta $C(\Delta C)$ e o Delta $\mathrm{N}(\Delta \mathrm{N})$ tendo como referência o estoque de $\mathrm{C}$ e de $\mathrm{N}$, obtidos na área de Cerrado (cerradão e cerrado sensu stricto). Os valores de estoque obtidos no cerradão (com os manejos implementados CG1, TCC e PB), em Mg ha ${ }^{-1}$, foram: COT = 283,6; COP = 154,$5 ; \mathrm{COAM}=126,7 ; \mathrm{NT}=8,8 ; \mathrm{NOP}=1,7 ; \mathrm{NOAM}=7,1$. Enquanto que, no cerrado sensu stricto (com os manejos CG2, PCv e PN), os estoques foram de, em $\mathrm{Mg} \mathrm{ha}^{-1}$ : $\mathrm{COT}=136,7 ; \mathrm{COP}=30,5 ; \mathrm{COAM}=106,0 ; \mathrm{NT}=8,9 ; \mathrm{NOP}=0,4 ; \mathrm{NOAM}=8,5$.

O Delta C foi obtido pela subtração dos valores de estoque no Cerradão e do Cerrado sensu stricto pelo estoque em cada sistema de uso. Quando negativo, os valores 
indicam que houve redução dos estoques e quando positivo, o sistema promoveu acréscimo nos estoques de carbono, nas diferentes frações.

A análise estatística univariada foi realizada utilizando-se o software estatístico SAS versão 9.1 (SAS, 2008) e constituiu de análise de variância (ANOVA) em relação aos dados obtidos em cada manejo sob cerradão ou cerrado sensu stricto, repetições (5), profundidades $(0-10$ e $10-20 \mathrm{~cm})$ e interação tratamento*profundidade, seguida de teste de média Tukey, ao nível de 5\% de probabilidade, conforme a sensibilidade do método para as médias dos teores de $\mathrm{C}$ e $\mathrm{N}$ nas diferentes frações da MOS (COT, COP, COAM, NT, NOP e NOAM) e nas relações das frações granulométricas de $\mathrm{C}$ e $\mathrm{N}$ ao COT e NT. Ademais, os dados de todas as variáveis foram submetidos conjuntamente à análise de componentes principais, utilizando-se o software estatístico XLSTAT 2011.

\subsection{RESULTADOS E DISCUSSÃO}

\subsubsection{Teor e distribuição de $\mathrm{C}$ e $\mathrm{N}$ nas frações granulométricas da matéria orgânica}

De acordo com as Figuras 30A e 31A, verifica-se que o COT reduziu à medida que se aumentou a profundidade da coleta das amostras de solo. O COT variou, nas áreas manejadas sob Cerradão, de 28,78 a 101,14 $\mathrm{g} \mathrm{kg}^{-1} ; 24,83$ a $65,75 \mathrm{~g} \mathrm{~kg}^{-1} ; 20,33$ a 47,03 $\mathrm{g} \mathrm{kg}^{-1}$; e 21,34 a 41,75 $\mathrm{g} \mathrm{kg}^{-1}$, nas profundidades de 0-5, 5-10, 10-20 e 20-30 $\mathrm{cm}$, respectivamente (Figura 30A). Nas áreas sob Cerrado sensu stricto, o COT variou, nas áreas manejadas sob cerradão, de 30,10 a 42,76 $\mathrm{g} \mathrm{kg}^{-1} ; 28,47$ a 36,27 $\mathrm{g} \mathrm{kg}^{-1} ; 23,58$ a $31,09 \mathrm{~g} \mathrm{~kg}^{-1}$; e 22,08 a 31,39 $\mathrm{g} \mathrm{kg}^{-1}$, nas profundidades de 0-5, 5-10, 10-20 e 20-30 cm, respectivamente (Figura 31A). 

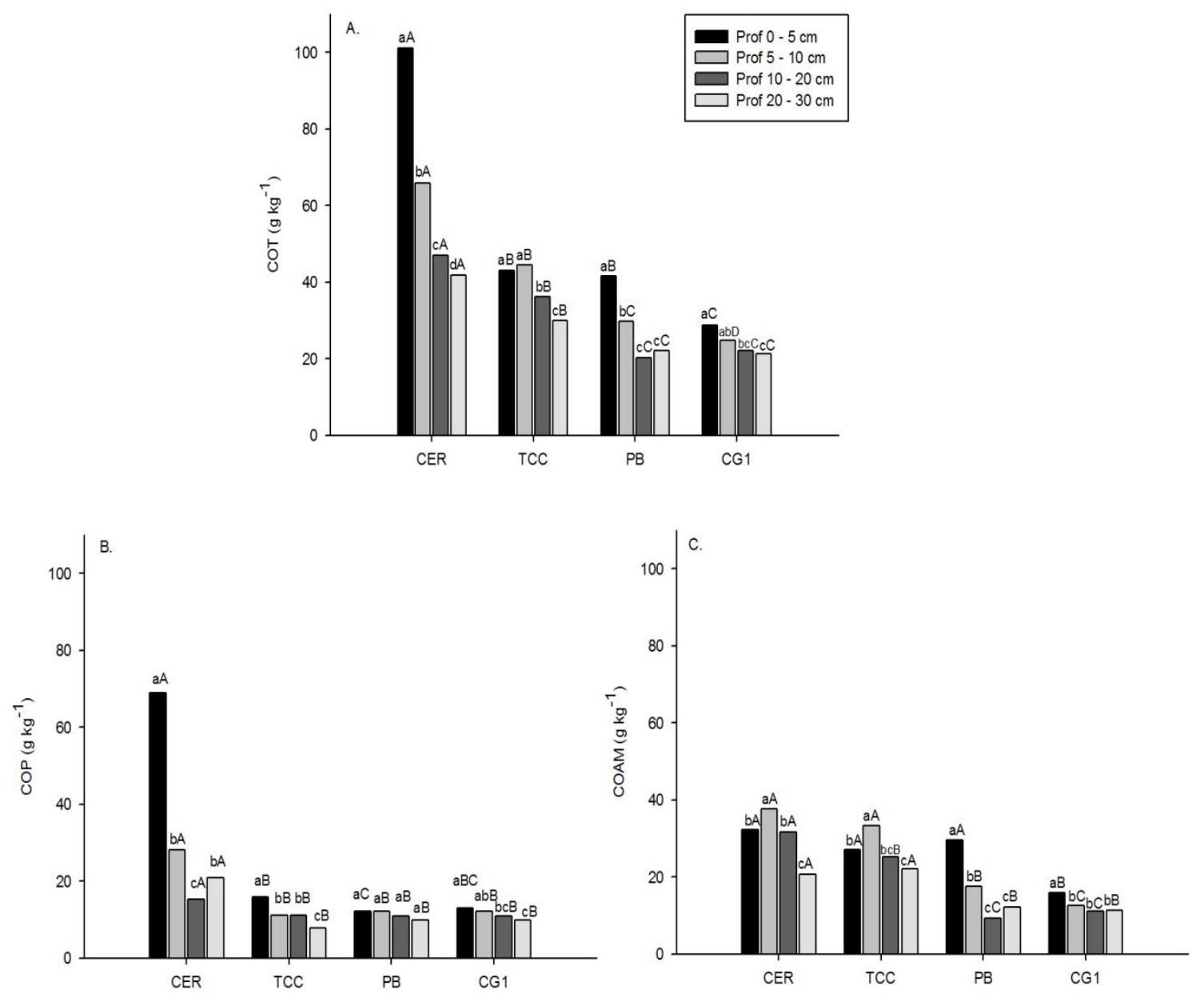

Figura 30. Teores do carbono orgânico total (COT), carbono orgânico particulado (COP) e carbono orgânico associado aos minerais (COAM) nas áreas manejadas sob cerradão. CER: cerradão; TCC: tangerina com consórcio; PB: pastagem de braquiárias e CG1: plantio convencional de grãos. Médias seguidas de mesma letra maiúscula comparam os usos em cada profundidade e minúscula, comparam as profundidades para cada uso (Tukey; $\mathrm{p}<0,05$ ).

Na Figura 30A, em todas as profundidades, o CER apresentou o maior valor significativo de COT. Alcântara Neto et al. (2011), Bezerra et al. (2014), Giácomo et al. (2015) também observaram que, independentemente da camada avaliada, a área de cerradão apresentou os maiores teores de $\mathrm{C}$ orgânico em relação às demais formações vegetais avaliadas por haver maior aporte de serapilheira e à quantidade de nutrientes aportada nesta área. 

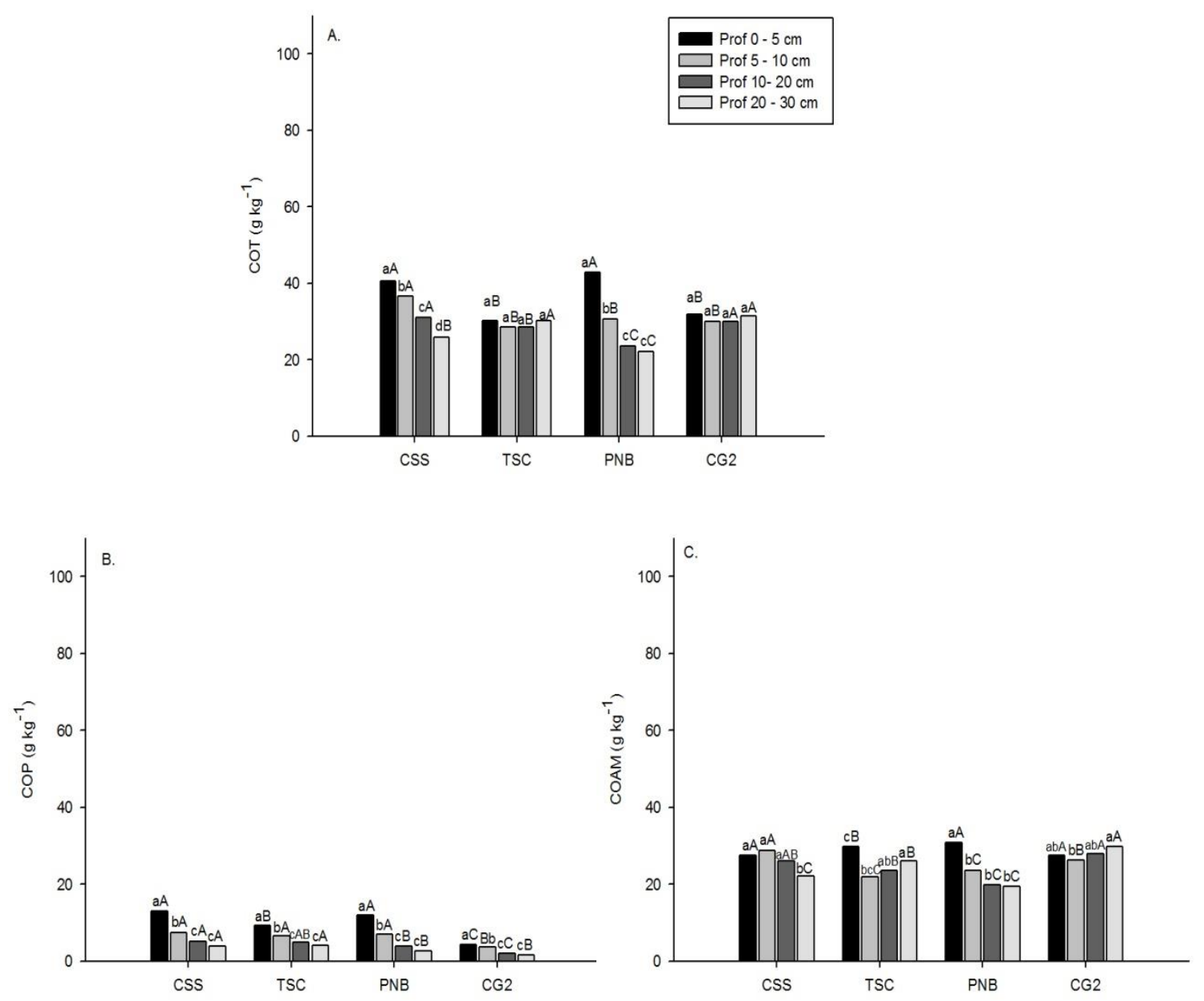

Figura 31. Teores do carbono orgânico total (COT), carbono orgânico particulado (COP) e carbono orgânico associado aos minerais (COAM) nas áreas manejadas sob Cerrado sensu stricto. CSS: cerrado sensu stricto; TSC: tangerina sem consórcio; PNB: pastagem de plantas nativas e braquiárias e CG2: plantio convencional de grãos. Médias seguidas de mesma letra maiúscula comparam os usos em cada profundidade e minúscula, comparam as profundidades para cada uso (Tukey; $\mathrm{p}<0,05$ )

De acordo com a Figura 31A, nas culturas implantadas sob Cerrado sensu stricto, na profundidade de 0-5 cm, o CSS apresentou valor de COT semelhante ao PNB, porém os manejos convencionais reduziram o COT em $21 \%$ e $26 \%$ para CG2 e TSC, respectivamente. Nas profundidades de 5-10 e 10-20 cm, os manejos CG2, TSC e 
PNB tiveram valores de COT semelhantes, porém na profundidade de 20-30 cm, o PNB passou a ter o menor valor de COT.

Observa-se que as pastagens degradada (PB) (Figura 30A) e natural (PNB) (Figura 31A) apresentaram maior valor de COT na profundidade de $0-5 \mathrm{~cm}$, em comparação com o CG1 e CG2 e TSC, pois Pulrolnik et al. (2009) e Wendling et al. (2011) argumentam que a pastagem possui sistema radicular de ciclagem rápida, e devido ao elevado aporte de material vegetal nas camadas mais superficiais e ausência de preparo do solo após a sua implantação favorecem o maior teor de COT. No entanto, as áreas sob pastagem (PB e PNB) não ocasionaram aumento de COT com o aumento da profundidade, discordando dos resultados obtidos por Viera et al. (2014) e (2015) que observaram que em áreas de pastagem houve aumento na concentração de COT com o aumento da profundidade. Para esses autores, pelo fato do sistema radicular das gramíneas atingirem camadas mais profundas, com a morte dessas raízes em profundidade, a sua decomposição acaba liberando nutrientes nessas camadas, mantendo ou aumentando os teores de C.

Ademais, os resultados revelaram que o uso da terra com manejo conservacionista (TCC) foi o que, depois do CER, com maior teor de COT, indicando que a adoção de práticas como rotação de cultura, cobertura permanente do solo e incorporação de resíduos orgânicos podem garantir a produção de alimentos com reduzido impacto no balanço de carbono do solo, como observado por Khorramdel et al. (2013) e Costa et al. (2013).

Com relação ao COP nas áreas manejadas no Cerradão (Figura 30B), verifica-se que os valores de COP variaram de 12,21 a 68,91 $\mathrm{g} \mathrm{kg}^{-1} ; 11,05$ a 28,21 $\mathrm{g} \mathrm{kg}^{-}$ ${ }^{1} ; 10,98$ a 15,35 $\mathrm{g} \mathrm{kg}^{-1} ; 7,80$ a 20,85 $\mathrm{g} \mathrm{kg}^{-1}$, nas profundidades de 0-5, 5-10, 10-20 e 20$30 \mathrm{~cm}$, respectivamente. Já nas áreas manejadas no Cerrado sensu stricto, os valores de COP variaram de 4,39 a $12,94 \mathrm{~g} \mathrm{~kg}^{-1} ; 3,74$ a $7,49 \mathrm{~g} \mathrm{~kg}^{-1} ; 2,09$ a $5,11 \mathrm{~g} \mathrm{~kg}^{-1} ; 1,69$ a 4,13 
$\mathrm{g} \mathrm{kg}^{-1}$, nas profundidades de 0-5, 5-10, 10-20 e 20-30 cm, respectivamente (Figura 31B). Observa-se que esses valores estão acima dos encontrados por outros autores no Cerrado (Figueiredo et al., 2010; Schiavo et al., 2011; Coser et al., 2012; Souza, 2013) em solos argilosos e muito argilosos. Os maiores valores de COP foram encontrados nas camadas superficiais do solo, diminuindo em profundidade. Essa estratificação do COP também foi observada por Carmo et al. (2012) e Nunes et al. (2011).

Os maiores valores de COP foram no CER, cujos valores reduziram com o aumento da profundidade (Figura 30B), o que indica o constante aporte de serapilheira nas camadas superficiais do solo, associados à sua qualidade (serapilheira mais lignificada), mantendo o estado estável nas adições e perdas de COT (Urquiaga et al., 2005; Loss et al., 2012; Bezerra et al., 2013), e, consequentemente, nas adições e perdas de COP, além da ausência de interferência antrópica nesta área.

Na profundidade de $0-5 \mathrm{~cm}$ (Figura 30B), nas culturas implantadas sob cerradão, verifica-se que os manejos TCC, CG1 e PB reduziram o valor de COP, em comparação a área nativa, em 77\%, $81 \%$ e 82\%, respectivamente. Nas demais profundidades, esses manejos tiveram comportamento semelhantes, reduzindo o valor de COP na mesma proporção. Vale destacar que, com exceção do CER, os teores médios de COP entre as profundidades mantiveram-se estáveis, estes resultados são esperados por não haver um aporte significativo, ao longo do tempo, de resíduos vegetais aos sistemas por conta dos manejos adotados.

Já nas culturas implantadas sob Cerrado sensu stricto, na profundidade de 0$5 \mathrm{~cm}$ (Figura 31B), o CSS teve valor de COP semelhante ao PNB, porém os demais manejos reduziram o COP em $29 \%$ e $66 \%$ para TSC e CG2, respectivamente. Nas profundidades de 5-10 e 10-20 cm, o CSS e os manejos TSC e PNB tiveram valores de COP semelhantes, com o CG2, apresentando o menor valor. Porém, na profundidade de 20-30 cm, o CSS e o TSC apresentaram os maiores valores de COP. 
Segundo Blair et al. (1998), o COP é composto por hifas de fungos, raízes e resíduos animais e vegetais, que corresponde à fração lábil da MOS e é muito responsivo às mudanças decorrentes das práticas de manejo do solo. Assim, pode-se inferir que as práticas de manejo conservacionista e convencional utilizadas pelos quilombolas de Mesquita estão de certa forma desfavorecendo a manutenção do COP em comparação ao CER. Estudos feitos por Souza et al. (2009), Loss et al. (2011), Nunes et al. (2011), com sistemas de plantio direto, sem revolvimento do solo, associado ao uso de plantas de cobertura solteira e consorciadas revelam que o manejo adequado do solo pode, dentre outros benefícios, melhorar a qualidade da MOS e aumentar o COP, sendo uma possibilidade de manejo a ser adotado pelos quilombolas.

Com relação ao COAM, os valores variaram de 15,85 a $32,23 \mathrm{~g} \mathrm{~kg}^{-1} ; 12,68$ a $37,58 \mathrm{~g} \mathrm{~kg}^{-1} ; 9,34$ a $31,68 \mathrm{~g} \mathrm{~kg}^{-1} ; 11,35$ a $22,12 \mathrm{~g} \mathrm{~kg}^{-1}$, nas profundidades de $0-5,5-10$, 10-20 e 20-30 cm, respectivamente, nas áreas sob Cerradão (Figura 30C). Nas áreas sob Cerrado sensu stricto, os valores variaram de 30,87 a 27,55 $\mathrm{g} \mathrm{kg}^{-1} ; 21,82$ a 28,77 $\mathrm{g} \mathrm{kg}^{-1}$; 19,78 a 27,89 $\mathrm{g} \mathrm{kg}^{-1} ; 19,45$ a $29,70 \mathrm{~g} \mathrm{~kg}^{-1}$, nas profundidades de $0-5,5-10,10-20$ e 20$30 \mathrm{~cm}$, respectivamente (Figura 31C).

Observa-se que os valores de COAM foram maiores que os COP. Segundo Figueiredo et al. (2010), há uma correlação negativa entre COP e COAM, indicando que os processos de formação dessas frações são opostos. Ou seja, para que se tenham maiores teores de COAM no solo é necessário que ocorra maior decomposição (diminuição) dos teores de COP para posterior associação com os minerais do solo nos tamanhos de silte e argila.

Verifica-se ainda que o CER foi o único manejo, na profundidade de 0-5 $\mathrm{cm}$, que o valor de COP foi maior que o de COAM (Figura 30C), indicando a maior quantidade de carbono lábil, existente nessa área. No entanto, nos demais manejos e profundidades, a distribuição do C foi maior na fração associada aos minerais do que na 
particulada (Figura 30B e 30C). Na profundidade de 0-5 cm (Figura 30C), nas culturas implantadas sob Cerradão, verifica-se que os manejos PB e TCC foram semelhantes ao CER e o CG1 reduziram o valor de COAM, em 51\%. Nas demais profundidades, verifica-se que o manejo conservacionista (TCC) ocasionou as menores reduções nos teores de COAM, do que os manejos convencionais (CG1 e PB).

Já nas culturas implantadas sob Cerrado sensu stricto, na profundidade de 0$5 \mathrm{~cm}$ (Figura 31C), o COAM foi semelhante no CSS, PNB e CG2 e menor no TSC, na profundidade de 10-20 cm, o COAM foi maior no cerrado nativo Nas profundidade de 10-20 cm, o CSS e os manejos TSC e CG2 tiveram valores de COAM semelhantes, com o PNB, apresentando o menor valor. De maneira geral, os valores de COAM mantiveram estáveis nas profundidades estudadas.

Ademais, o teor de COP no CER foi maior que no CSS e PNB, demonstrando a melhor qualidade da MOS sob cerradão. Portanto, a substituição da vegetação CER por cultivo (CG1, TCC e PB) provocou redução mais acentuada da fração COP, do que nas áreas cultivadas sob CSS, já que nessas áreas há menor quantidade e qualidade de resíduos vegetais.

$\mathrm{Na}$ tabela 25, encontram-se as proporções de $\mathrm{C}$ na matéria orgânica particulada nos manejos implantadas no Cerradão e no Cerrado sensu stricto. De maneira geral, observa-se uma maior proporção de $\mathrm{C}$ associado aos minerais em todas as profundidades, havendo diferenças entre manejos, bem como valores maiores nas camadas superficiais.

De acordo com a tabela 25 , observa-se que a proporção de COP nos teores do COT (COP:COT) foi maior nas profundidades superficiais, nas áreas manejadas sob cerradão. A proporção COP:COT variou de 29 a 68\%, 25 a 43\%, 31 a $54 \%$ e de 25 a $50 \%$ nas profundidades de 0-5, 5-10, 10-20 e 20-30 cm, respectivamente. Assim, de maneira geral, a maior proporção de COP:COT foi nas áreas manejadas sob cerradão. 
Observa-se que na profundidade de $0-5 \mathrm{~cm}$, essa proporção aumentou da seguinte forma: $\mathrm{CER}>\mathrm{CG} 1>\mathrm{TCC}>\mathrm{PB}$. A proporção foi constante em todas as profundidades para CG1 (42\%) e aumentou no Past, variando de 29 a 54\%. As proporções de COAM:COT foram maiores que a COP:COT, com exceção do CER, no qual a relação COAM:COT foi menor na profundidade de $0-5 \mathrm{~cm}$.

Tabela 25. Relações entre os teores de $\mathrm{C}$ das frações particulada (\%COP/COT) e associada aos minerais (\%COAM/COT) e o teor de $\mathrm{C}$ total, nas profundidades de 0-5, 5-10, 10-20 e 20-10 cm, em diferentes tipos de usos do solo.

\begin{tabular}{|c|c|c|c|c|c|}
\hline \multirow[t]{2}{*}{ Relação } & \multirow{2}{*}{$\begin{array}{l}\text { Profundidade } \\
\text { (cm) }\end{array}$} & \multicolumn{4}{|c|}{ Usos da terra* } \\
\hline & & CER & TCC & PB & CG1 \\
\hline \multirow{4}{*}{$\% \mathrm{COP} / \mathrm{COT}$} & $0-5$ & $68,13 \mathrm{aA}$ & $37,11 \mathrm{aC}$ & $29,32 \mathrm{cC}$ & $44,97 \mathrm{aB}$ \\
\hline & $5-10$ & $42,94 \mathrm{bA}$ & $25,00 \mathrm{bB}$ & $40,86 \mathrm{bA}$ & $42,94 \mathrm{aA}$ \\
\hline & $10-20$ & $32,60 \mathrm{cB}$ & $30,56 \mathrm{abB}$ & $54,10 \mathrm{aA}$ & $49,78 \mathrm{aA}$ \\
\hline & $20-30$ & $50,27 \mathrm{bA}$ & $25,95 \mathrm{bB}$ & $45,06 \mathrm{bA}$ & $42,56 \mathrm{aA}$ \\
\hline \multirow{5}{*}{$\% \mathrm{COAM} / \mathrm{COT}$} & $0-5$ & $32,87 \mathrm{cB}$ & $62,98 \mathrm{bB}$ & $70,68 \mathrm{aA}$ & $55,03 \mathrm{aA}$ \\
\hline & $5-10$ & $57,05 \mathrm{bB}$ & $74,99 \mathrm{cA}$ & $59,14 \mathrm{bB}$ & $51,10 \mathrm{aB}$ \\
\hline & $10-20$ & $67,40 \mathrm{aA}$ & $69,44 \mathrm{abA}$ & $45,90 \mathrm{cB}$ & $50,22 \mathrm{aB}$ \\
\hline & $20-30$ & $49,73 \mathrm{bB}$ & $74,05 \mathrm{aA}$ & $50,22 \mathrm{aB}$ & $52,79 \mathrm{aB}$ \\
\hline & & CSS & TSC & PNB & CG2 \\
\hline \multirow{4}{*}{$\% \mathrm{COP} / \mathrm{COT}$} & $0-5$ & $31,96 \mathrm{aA}$ & $30,64 \mathrm{aA}$ & $27,96 \mathrm{aA}$ & $33,75 \mathrm{aB}$ \\
\hline & $5-10$ & $20,61 \mathrm{bA}$ & $22,69 \mathrm{bA}$ & $23,18 \mathrm{aA}$ & $12,51 \mathrm{aB}$ \\
\hline & $10-20$ & $16,46 \mathrm{bcA}$ & $17,36 \mathrm{bcA}$ & $16,23 \mathrm{bA}$ & $6,97 \mathrm{bB}$ \\
\hline & $20-30$ & $15,18 \mathrm{cA}$ & $13,46 \mathrm{cA}$ & $6,97 \mathrm{bB}$ & $5,39 \mathrm{cB}$ \\
\hline \multirow{4}{*}{$\% \mathrm{COAM} / \mathrm{COT}$} & $0-5$ & $68,04 \mathrm{cB}$ & $69,36 \mathrm{cB}$ & $72,03 \mathrm{bB}$ & $82,25 \mathrm{cA}$ \\
\hline & $5-10$ & $79,39 \mathrm{bB}$ & $76,56 \mathrm{bB}$ & $77,25 \mathrm{bB}$ & $87,49 \mathrm{cA}$ \\
\hline & $10-20$ & $83,54 \mathrm{abB}$ & $82,64 \mathrm{aB}$ & $83,76 \mathrm{aB}$ & $93,03 \mathrm{bA}$ \\
\hline & $20-30$ & $84,82 \mathrm{aB}$ & $83,76 \mathrm{aB}$ & $88,06 \mathrm{aB}$ & $94,61 \mathrm{aA}$ \\
\hline
\end{tabular}

As proporções de COP e COAM nas áreas manejadas sob Cerrado sensu stricto estão na tabela 25 e revelam comportamento semelhante aos das áreas sob Cerradão. As proporções de COP foram maiores na camada mais superficial. E, como relatado e explicado anteriormente, há maior proporção de COAM do que COP.

O N total e nas frações granulométricas da MOS foram influenciados pelos usos da terra adotados pelos quilombolas, havendo diferenças entre as profundidades 
estudadas (Figuras 32 e 33). Para Santos et al. (2008), o nitrogênio corresponde a uma importante fração da MOS e apresenta variação em seu conteúdo, conforme o tipo do material orgânico que é depositado no solo.

O N total nos diversos uso da terra sob Cerradão, em geral, diminuiu com o aumento da profundidade (Figura 32A), variando de 1,69 a 3,13 $\mathrm{g} \mathrm{kg}^{-1}, 1,47$ a 2,73 g kg1, 1,58 a $3,28 \mathrm{~g} \mathrm{~kg}^{-1}$ e 1,09 a $1,98 \mathrm{~g} \mathrm{~kg}^{-1}$, nas profundidades de $0-5,5-10,10-20$ e 20-30 $\mathrm{cm}$, respectivamente. Em geral, o teor de NOT teve o seguinte comportamento: TCC $>$ CG1 $>$ CER $>$ PB, sendo a maior disponibilidade de $\mathrm{N}$ encontrada nos sistemas onde houve adição de nitrogênio, como foi o caso do TCC e CG1 (Figura 32A). Diferentemente dos resultados encontrados por Urquiaga et al. (2005) e Bezerra et al. (2013), o cerradão (CER) não apresentou os maiores valores de NT, com exceção da profundidade de 10-20 $\mathrm{cm}$. Esse comportamento do CER pode ser explicado pela relação $\mathrm{CN}$ que foi de 47, 31, 18 e 28, nas profundidades de 0-5, 5-10, 10-20 e 20-30 cm, respectivamente. Para Moreira \& Siqueira (2006), relação CN abaixo de 20 indica predomínio do processo de mineralização, favorecendo a decomposição e a disponibilidade de nutrientes para o solo. Relação CN entre 20 e 30, a imobilização é igual a mineralização, ficando a disponibilidade de $\mathrm{N}$ inalterada. A relação $\mathrm{CN}$ maior que 30 indica que a imobilização é maior que a mineralização, havendo baixa disponibilidade de nutrientes.

Entre todos os usos da terra, o PB apresentou o menor teor de NT, para a maioria das profundidades, o que pode ser explicado pelo fato desse sistema não receber adubação nitrogenada há muito tempo, bem como por ser o manejo, depois do CER, no qual a relação $\mathrm{CN}$ ficou na média de 25 , indicando que a mineralização é semelhante à imobilização, onde a disponibilidade de $\mathrm{N}$ se torna inalterada. Todavia, há trabalhos nos quais pastagens bem manejadas promovem teor elevado de NOT ao solo, como observado por Pulrolnik et al.(2009), Winck et al. (2014). 

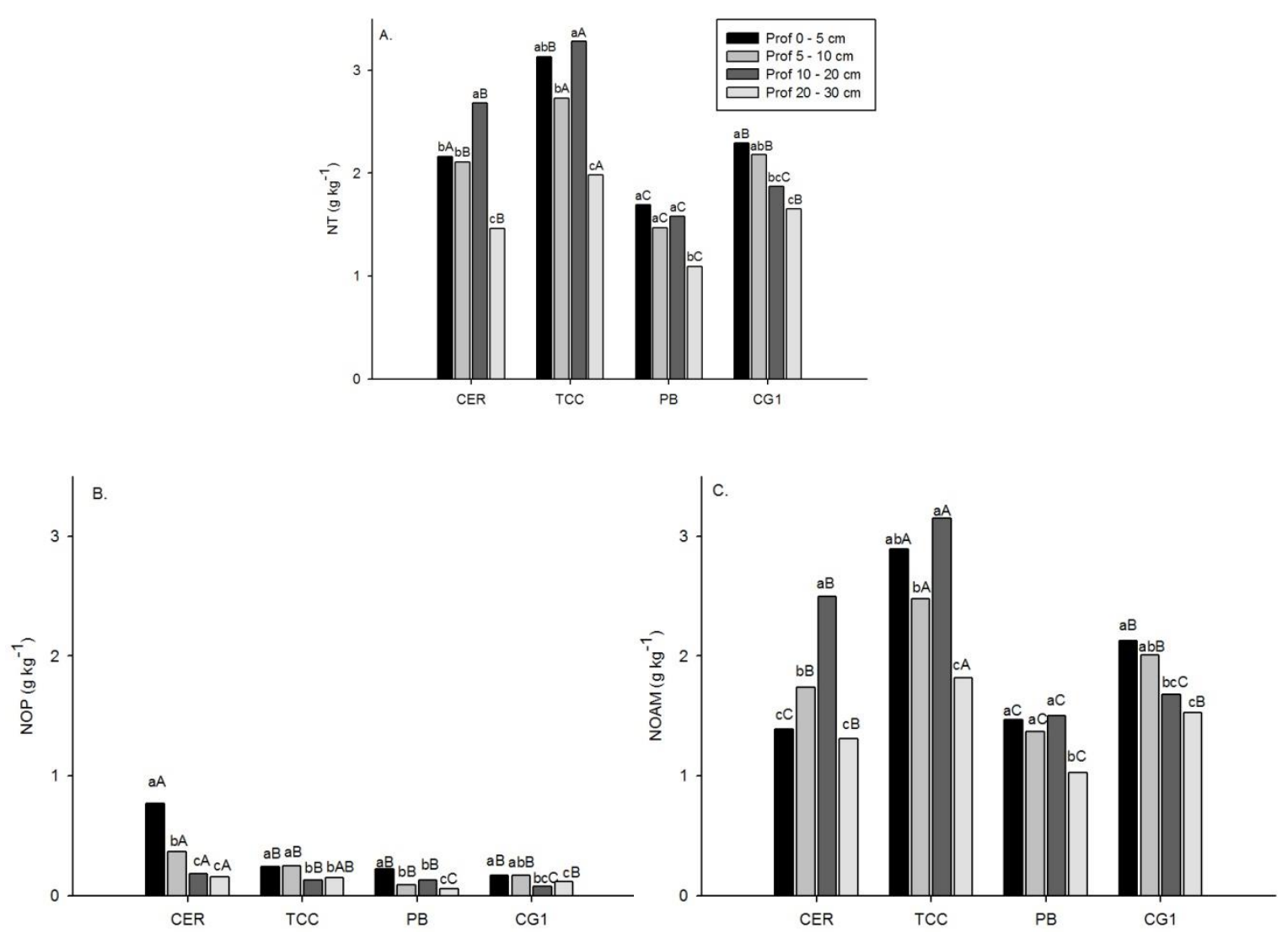

Figura 32. Teores do nitrogênio total (NT), nitrogênio orgânico particulado (COP) e carbono orgânico associado aos minerais (NOAM) nas áreas manejadas sob cerradão. CER: cerradão; TCC: tangerina com consórcio; PB: pastagem degradada e CG1: plantio convencional de grãos. Médias seguidas de mesma letra maiúscula comparam os usos da terra em cada profundidade e minúscula, comparam as profundidades para cada uso (Tukey; $\mathrm{p}<0,05$ )

O N total sob Cerrado sensu stricto (Figura 33A) também diminuiu com o aumento da profundidade, variando de 2,77 a 3,39 $\mathrm{g} \mathrm{kg}^{-1}, 2,11$ a $2,76 \mathrm{~g} \mathrm{~kg}^{-1}, 1,57$ a 1,55 $\mathrm{g} \mathrm{kg}^{-1}$ e 1,47 a 1,83 $\mathrm{g} \mathrm{kg}^{-1}$, nas profundidades de 0-5, 5-10, 10-20 e 20-30 cm, respectivamente.

O teor de NT foi semelhante, em todas as profundidades, nos manejos PNB e TSC. No geral, CG2 apresentou menor valor de NT em todas as profundidades. Em relação ao CSS, apenas na profundidade de $0-5 \mathrm{~cm}$ que esse manejo apresentou NT 
menor que TSC e PNB. Verifica-se que no manejo TSC os maiores valores de NOT é devida a adubação de N na área, que foi menor na área do CG2 (Figura 33A).
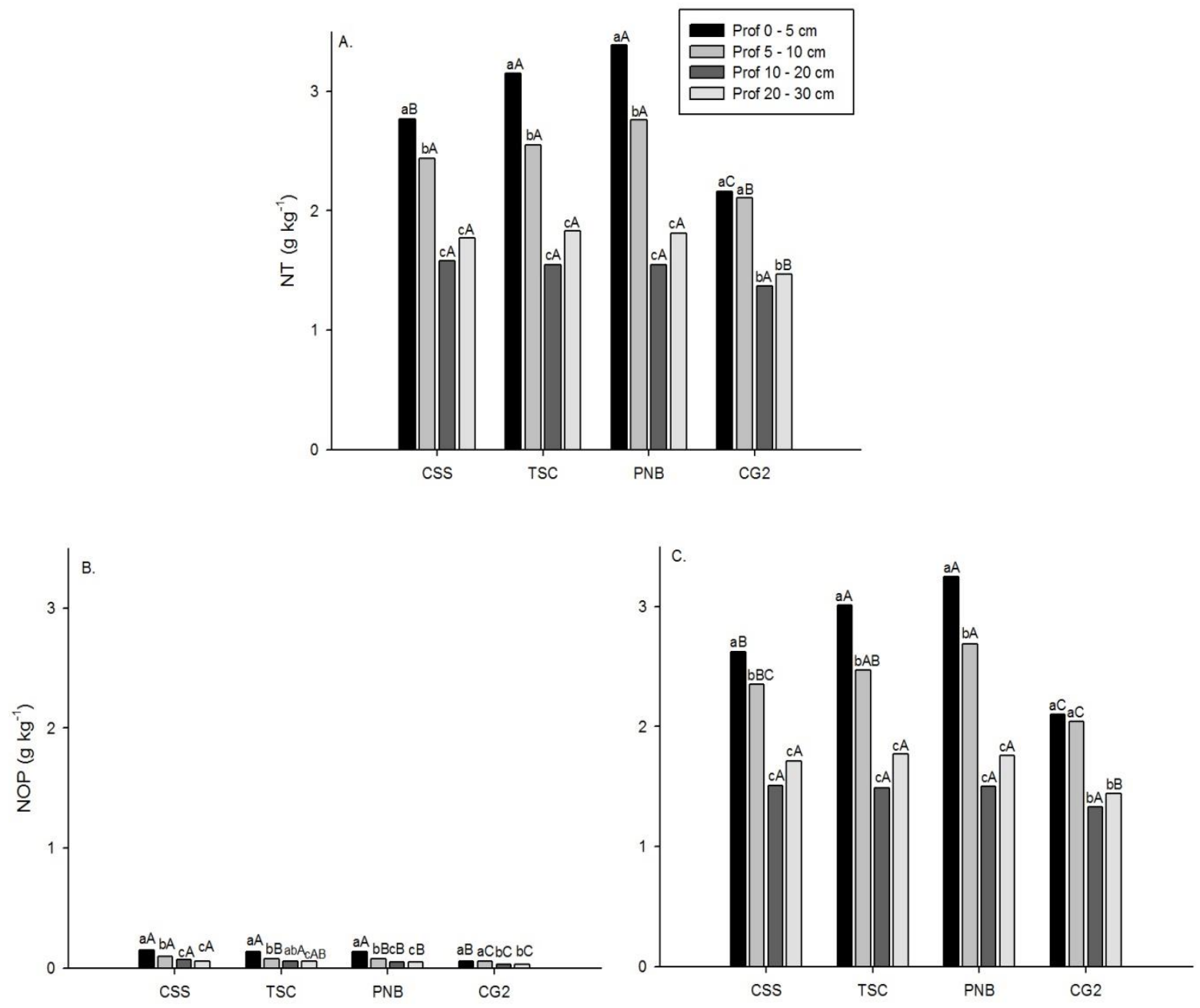

Figura 33. Teores do nitrogênio total (NT), nitrogênio orgânico particulado (COP) e carbono orgânico associado aos minerais (NOAM) nas áreas manejadas sob Cerrado sensu stricto. CSS: cerrado sensu stricto; TSC: tangerina sem consórcio; PNB: pastagem de plantas nativas e braquiárias e CG2: plantio convencional de grãos. Médias seguidas de mesma letra maiúscula comparam os usos em cada profundidade e minúscula, comparam as profundidades para cada uso (Tukey; $\mathrm{p}<0,05$ )

Nas áreas sob Cerradão, os valores do NOP variaram de 0,17 a $0,77 \mathrm{~g} \mathrm{~kg}^{-1}$, 0,09 a $0,37 \mathrm{~g} \mathrm{~kg}^{-1}, 0,08$ a $0,18 \mathrm{~g} \mathrm{~kg}^{-1}, 0,06$ a $0,16 \mathrm{~g} \mathrm{~kg}^{-1}$, nas profundidades de $0-5,5-10$, 10-20 e 20-30 cm, respectivamente (Figura 32B) nos diferentes manejos. Enquanto que 
os valores de NOTAM foram de 1,39 a 2,89 $\mathrm{g} \mathrm{kg}^{-1} ; 1,37$ a 2,48 $\mathrm{g} \mathrm{kg}^{-1}, 1,50$ a 3,15 $\mathrm{g} \mathrm{kg}^{-1}$ e 1,03 a 1,82 $\mathrm{g} \mathrm{kg}^{-1}$, nas profundidades de 0-5, 5-10, 10-20 e 20-30 cm, respectivamente (Figura 32C).

Nas áreas sob Cerrado sensu stricto, os valores do NOP variaram de 0,06 a $0,15 \mathrm{~g} \mathrm{~kg}^{-1}, 0,06$ a $0,10 \mathrm{~g} \mathrm{~kg}^{-1}, 0,03$ a $0,07 \mathrm{~g} \mathrm{~kg}^{-1}, 0,03$ a $0,06 \mathrm{~g} \mathrm{~kg}^{-1}$, nas profundidades de 0-5, 5-10, 10-20 e 20-30 cm, respectivamente (Figura 33B). Enquanto que os valores de NOTAM foram de 2,10 a 3,25 $\mathrm{g} \mathrm{kg}^{-1} ; 2,04$ a 2,69 $\mathrm{g} \mathrm{kg}^{-1}, 1,33$ a $1,51 \mathrm{~g} \mathrm{~kg}^{-1}$ e 1,44 a $1,77 \mathrm{~g} \mathrm{~kg}^{-1}$, nas profundidades de 0-5, 5-10, 10-20 e 20-30 cm, respectivamente (Figura 33C). Verifica-se que os valores de NOTAM foram superiores aos do NOP, conforme aconteceu com a distribuição do $\mathrm{C}$ nas frações granulométricas, indicando que o C e o N estão na fração de maior resistência no solo, devido às suas maiores interações com as partículas de argila.

Ainda, devido a fração particulada (COP e NOP) possuir alta labilidade (Bayer et al., 2002), o N, assim como o C, também sofrem alterações quando esta fração é afetada pelos sistemas de manejo. Assim, de acordo com a figura 32, verifica-se que o maior valor de NOP foi no CER, em todas as profundidades, em comparação aos demais manejos. No entanto, nos outros sistemas, nas profundidades de 0-5 e 5-10 cm, o NOP foi maior, indicando que, assim como o COP, as maiores variações nos teores de NOP são nas camadas mais superficiais do solo, reforçando a ideia da dependência desta fração da adição de resíduos vegetais para a manutenção de seus valores (Carmo et al., 2012). Os menores valores de NOP nos manejos TCC, PB e CG1 indicam que a palhada da parte aérea desses sistemas contribuiu para diminuir a matéria orgânica particulada na camada superficial com consequências na cobertura do solo e na disponibilidade de substrato para microrganismo, pela sua característica de maior labilidade. No caso dos manejos sob Cerrado sensu stricto (Figura 33B), verifica-se que o CSS apresentou valores de NOP semelhantes aos manejos PNB e TSC, e superior ao 
CG2, na camada de $0-5 \mathrm{~cm}$. Nas outras camadas, em geral, o CSS e TSC apresentaram maiores valores de NOP.

Com relação ao NOTAM, houve diferenças entre profundidades e usos da terra, em geral, os maiores valores encontrados nas camadas mais superficiais (Figuras 32C e 33C), onde os manejos se comportaram de maneira semelhante ao NT. Nas áreas sob cerradão (Figura 32C), na profundidade de 0-5 cm, o CER apresentou valor de NOTAM semelhante ao Past, nas profundidades de 5-10 e 20-30 cm o CER foi semelhante ao CG1, enquanto que na profundidade de 10-20, o valor de CER foi semelhante ao TCC. Assim, de maneira geral, o TCC teve o maior valor significativo de NOAM, e o PB apresentou o menor valor.

Nas áreas sob Cerrado sensu stricto (Figura 33C), o TSC e o PNB tiveram comportamento semelhantes, apresentando os maiores valores de NOAM em todas as profundidades. Os valores de NOAM diminuíram com a profundidade para todos os sistemas estudados.

As proporções de NOP e NOAM nos teores do NT (NOP:NT e NOAM:NT) variaram pouco entre os manejos e profundidades (Tabela 26). O CN1 apresentou 36\% de NOP e 64\% de NOAM, na profundidade de 0-5 cm, bem como, em geral, apresentou o maior valor dessas proporções nas demais profundidades. Os demais manejos apresentaram proporção média de NOP e NOAM de $8 \%$ e 92\%, respectivamente.

As relações nos manejos sob cerrado sensu stricto encontram-se na Tabela 26, as maiores proporções de NOP foram na profundidade de $0-5 \mathrm{~cm}$ para todas as áreas estudadas e entre os manejos, foi maior significativamente no CN2. O menor valor foi no CG2, e os manejos PCv e PN tiveram valores intermediários semelhantes. De maneira geral, verifica-se que os manejos apresentaram proporção média de NOP e NOAM de $3 \%$ e $97 \%$, respectivamente. 
Tabela 26. Relações entre os teores de $\mathrm{N}$ das frações particulada (\%NOP/NOT) e associada aos minerais (\%NOAM/NOT) e o teor de $\mathrm{N}$ total, nas profundidades de 0-5, 5-10, 10-20 e 20-10 cm, em diferentes tipos de usos do solo.

\begin{tabular}{|c|c|c|c|c|c|}
\hline \multirow[t]{2}{*}{ Relação } & \multirow{2}{*}{$\begin{array}{l}\text { Profundidade } \\
\text { (cm) }\end{array}$} & \multicolumn{4}{|c|}{ Manejos* } \\
\hline & & CER & TCC & PB & CG1 \\
\hline \multirow{4}{*}{$\% \mathrm{NOP} / \mathrm{NT}$} & $0-5$ & $35,93 \mathrm{aA}$ & $7,85 \mathrm{aC}$ & $12,93 \mathrm{aB}$ & $7,30 \mathrm{aC}$ \\
\hline & $5-10$ & $17,52 \mathrm{bA}$ & $9,20 \mathrm{aB}$ & $6,65 \mathrm{bC}$ & 7,77aBC \\
\hline & $10-20$ & $6,67 \mathrm{dAB}$ & $5,30 \mathrm{bB}$ & $6,32 \mathrm{bAB}$ & $7,81 \mathrm{aA}$ \\
\hline & $20-30$ & $10,94 \mathrm{cA}$ & $7,78 \mathrm{cB}$ & $5,27 \mathrm{cC}$ & $7,34 \mathrm{aB}$ \\
\hline \multirow{5}{*}{$\%$ NOAM/NT } & $0-5$ & $64,07 \mathrm{dC}$ & $92,15 \mathrm{bA}$ & $87,07 \mathrm{cB}$ & $92,70 \mathrm{aA}$ \\
\hline & $5-10$ & $82,47 \mathrm{cC}$ & $90,80 \mathrm{bB}$ & $93,34 \mathrm{bA}$ & $92,35 \mathrm{aAB}$ \\
\hline & $10-20$ & $93,32 \mathrm{aC}$ & $96,15 \mathrm{aA}$ & $95,07 \mathrm{aB}$ & $92,69 \mathrm{aC}$ \\
\hline & $20-30$ & $89,06 \mathrm{bC}$ & $92,21 \mathrm{bB}$ & $94,73 \mathrm{aA}$ & $92,66 \mathrm{aB}$ \\
\hline & & CSS & TSC & PNB & CG2 \\
\hline \multirow{4}{*}{$\% \mathrm{NOP} / \mathrm{NT}$} & $0-5$ & $5,30 \mathrm{aA}$ & $4,38 \mathrm{aB}$ & $4,16 \mathrm{aB}$ & $3,02 \mathrm{aC}$ \\
\hline & $5-10$ & $3,96 \mathrm{bA}$ & $3,23 \mathrm{bB}$ & $2,94 \mathrm{bB}$ & $2,94 \mathrm{aB}$ \\
\hline & $10-20$ & $3,59 \mathrm{bA}$ & $2,74 \mathrm{bB}$ & $2,45 \mathrm{bB}$ & $1,90 \mathrm{bC}$ \\
\hline & $20-30$ & $3,57 \mathrm{bA}$ & $2,97 \mathrm{bAB}$ & $2,63 \mathrm{bB}$ & $1,73 b C$ \\
\hline \multirow{4}{*}{$\%$ NOAM/NT } & $0-5$ & $94,69 b C$ & $95,62 b B$ & $95,84 \mathrm{cB}$ & $96,98 \mathrm{Ca}$ \\
\hline & $5-10$ & $96,04 \mathrm{aB}$ & $96,77 \mathrm{aA}$ & $97,06 \mathrm{abA}$ & $97,06 \mathrm{cA}$ \\
\hline & $10-20$ & $95,41 b C$ & $95,80 \mathrm{bBC}$ & $96,59 \mathrm{bB}$ & $97,54 \mathrm{Ba}$ \\
\hline & $20-30$ & $96,43 \mathrm{aC}$ & $97,03 \mathrm{aBC}$ & $97,54 \mathrm{bA}$ & $98,27 \mathrm{Aa}$ \\
\hline
\end{tabular}

Observa-se que de maneira geral, os valores de COT, COP e COAM e NT, NOP e NOAM, foram maiores nas áreas sob Cerradão. No entanto, as culturas implantadas sob Cerradão foram capazes de reduzir ainda mais os teores de $\mathrm{C}$ e $\mathrm{N}$ total e nas demais frações do que os manejos implantados no Cerrado sensu stricto.

\subsubsection{Análise multivariada}

Os resultados dos compartimentos de $\mathrm{C}$ e $\mathrm{N}$ nas frações granulométricas da MOS, referentes aos diferentes usos da terra estudados, foram ordenados por meio da ACP, para as profundidades de 0-5, 5-10, 10-20 e 20-30 cm (Figura 34)

A distribuição das variáveis analisadas mostrou variância acumulada de $82,16 \%, 82,33 \%, 83,85 \%, 74,1767,05 \%$ para os componentes principais nas profundidades de 0-5, 5-10, 10-20 e 20-30 cm, respectivamente. Nas profundidades de 0-5 e 5-10 cm, o eixo F1 separou dois grupos principais: CER e os demais manejos 
(CSS, CG1, CG2, TCC, TSC; PB e PNB) (Figura 34A e 34B). O CER foi separado dos demais manejos pelas frações COT, COP, NOP; \%COP:COT e \%NOP:NOT, possuindo ainda correlação negativa com as variáveis NOT, NOTAM e COAM. Nos demais manejos, as variáveis NOT, NOTAM e COAM foram maiores, possuindo correlação negativa com as frações COT, COP, NOP.

O agrupamento da PCA revela que em relação aos componentes da MOS que representam um bom indicador de sua qualidade, estão o carbono $(\mathrm{C})$ e o nitrogênio (N) oriundos das frações granulométricas, conforme observado por Conceição et al.(2005); Loss et al. (2009); (2011); Figueiredo et al. (2010), Carmo et al. (2012) e Rossi et al. (2012).

Na profundidade de $10-20 \mathrm{~cm}$, o eixo F1 separou três grupos principais: CER/TCC; PB/CG1 e PNB/TSC/CG2/CSS. O CER e TCC (Figura 34C). Os maiores valores de COT, NOT, NOP, NOTAM foram obtidos nos manejos CER/TCC. As maiores proporções de NOP:NOT e COP:COT e os menores valores de COAM que correspondem aos manejos do PB/CG1. Os demais manejos foram influenciados positivamente pelas variáveis COAM/COT e NOTAM/NOT, os quais apresentaram os menores valores das demais variáveis estudadas. Com relação à profundidade de 20-30 cm (Figura 34D), verifica-se que nas áreas sob Cerradão (CER, TCC, CG1 e PB) se agruparam, assim como os demais manejos, implantados no Cerrado sensu stricto (CSS, TSC, CG2 e PNB).

Verifica-se que a área nativa (CER) foi a área com a melhor qualidade da MOS, sendo tal fato explicado pelos elevados valores de COT, COP e NOP. De maneira geral, os demais manejos, incluindo o CSS e PNB, apresentaram os menores valores das variáveis estudadas, com exceção no NOT, cujo nutriente $(\mathrm{N})$ é adicionado nos manejos convencionais (CG1, CG2 e TSC) e conservacionista (PCs), havendo perdas consideráveis das frações estudadas quando se maneja agricolamente uma área nativa. 
A) $0-5 \mathrm{~cm}$

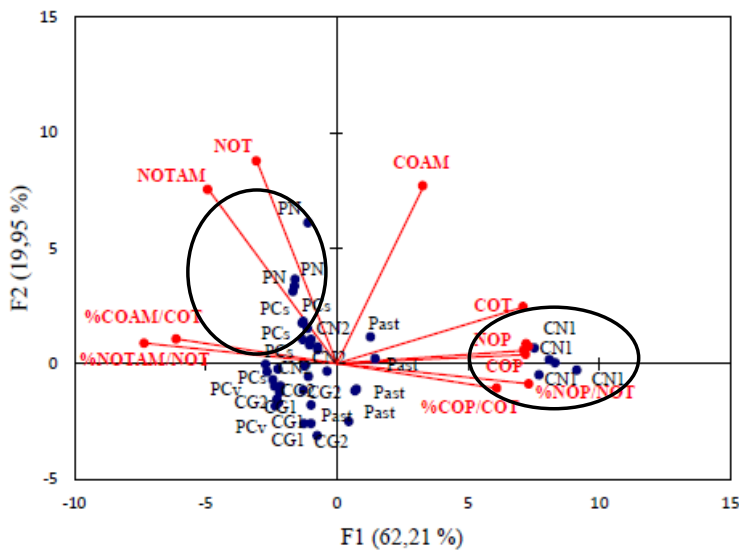

C) $10-20 \mathrm{~cm}$

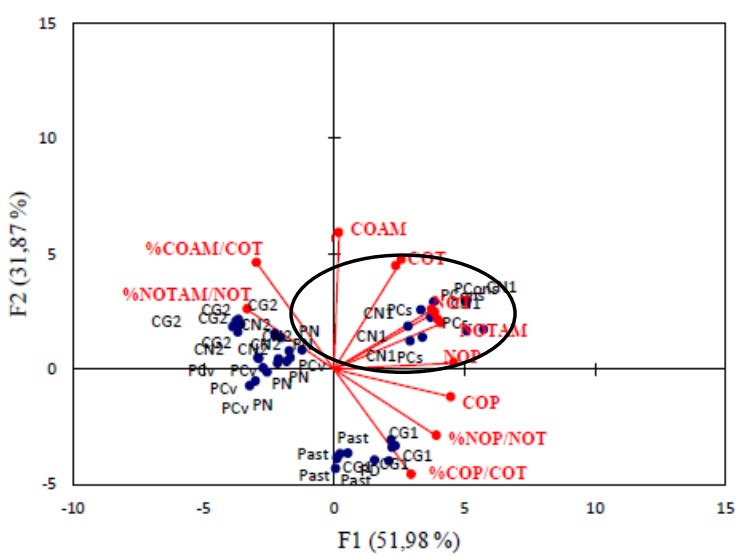

B) $5-10 \mathrm{~cm}$

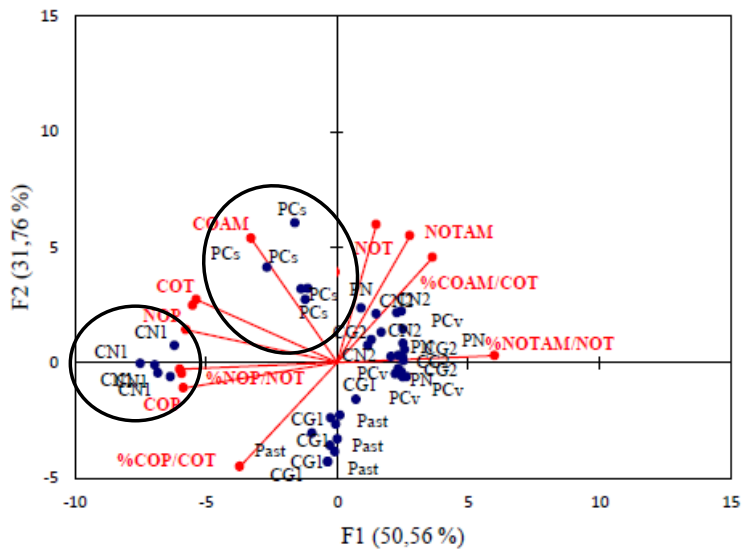

D) $20-30 \mathrm{~cm}$

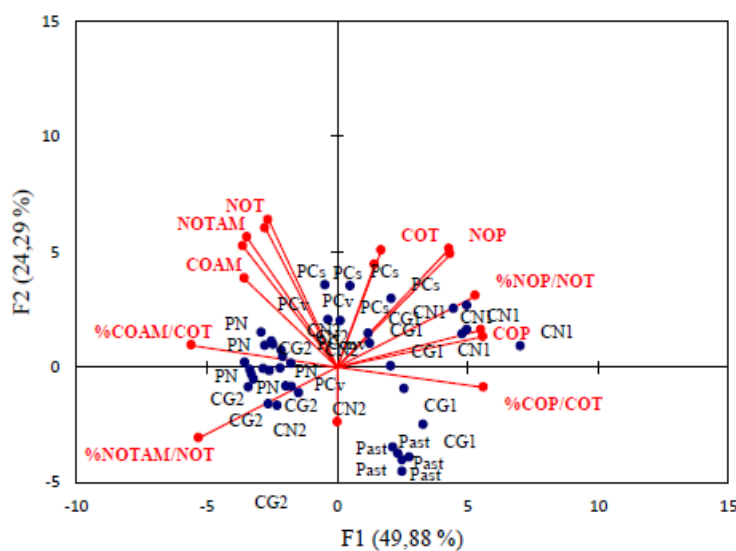

Figura 34. Análise de componentes principais dos teores de $\mathrm{C}$ e $\mathrm{N}$ totais e nas frações granulométricas da MOS nas profundidades de 0-5, 5-10, 10-20 e 20-30 cm, quando submetido a diferentes usos da terra. CER: Cerradão; TCC: Tangerina com consórcio; PB: pastagem braquiárias; CG1: plantio convencional de grãos; CSS: Cerrado sensu stricto; TSC: Tangerina sem consórcio; PNB: pastagem de plantas nativas e braquiárias; CG2: plantio convencional de grãos.

\subsubsection{Relação dos estoques de $\mathrm{C}$ e $\mathrm{N}$ entre sistemas de manejo e áreas nativas $(\Delta \mathrm{C}$ e} $\Delta \mathbf{N})$

$\mathrm{Na}$ figura 35 são apresentados os valores de $\Delta \mathrm{C}$ em $\mathrm{Mg} \mathrm{ha}^{-1}$ para os diferentes sistemas estudados, tendo os usos da terra sob Cerradão e do Cerrado sensu stricto, como referências, representados pelo valor zero. Observa-se que em todos os sistemas estudados houve decréscimo dos estoques de COT, COP e COAM, com 
exceção do manejo CG2 que apresentou acréscimo nos teores de COAM. Verifica-se que os usos da terra estudados conferem pouco aporte de fitomassa na superfície, já que os agricultores não utilizam plantas de cobertura. Para Leite et al. (2013), os estoques de carbono no solo são determinados pelo balanço das entradas de matéria orgânica, pelo aporte dos resíduos vegetais e pela aplicação de compostos orgânicos, bem como pelas saídas por meio da decomposição da matéria orgânica do solo.

Os teores de $\triangle \mathrm{COT}, \Delta \mathrm{COP}$ e $\triangle \mathrm{COAM}$ sofreram as maiores reduções nas áreas manejadas sob Cerradão (CG1, TCC e PB) do que sob Cerrado sensu stricto (CG2, TSC e PNB). O uso CG1 apresentou a maior redução dos estoques estudados $\left(\Delta \mathrm{COT}=-183,95 \mathrm{Mg} \mathrm{ha}^{-1} ; \Delta \mathrm{COP}=-106,61 \mathrm{Mg} \mathrm{ha}^{-1} ; \Delta \mathrm{COAM}=\mathrm{Mg} \mathrm{ha}^{-1}\right.$. O uso CG2 apresentou menor redução do $\Delta \mathrm{COT}\left(-5,95 \mathrm{Mg} \mathrm{ha}^{-1}\right)$ e acréscimo do $\triangle \mathrm{COAM}(+12,04$ $\left.\mathrm{Mg} \mathrm{ha}^{-1}\right)$, enquanto que a menor redução do estoque do COP foi no uso PNB (-2,81 Mg $\left.\mathrm{ha}^{-1}\right)$.

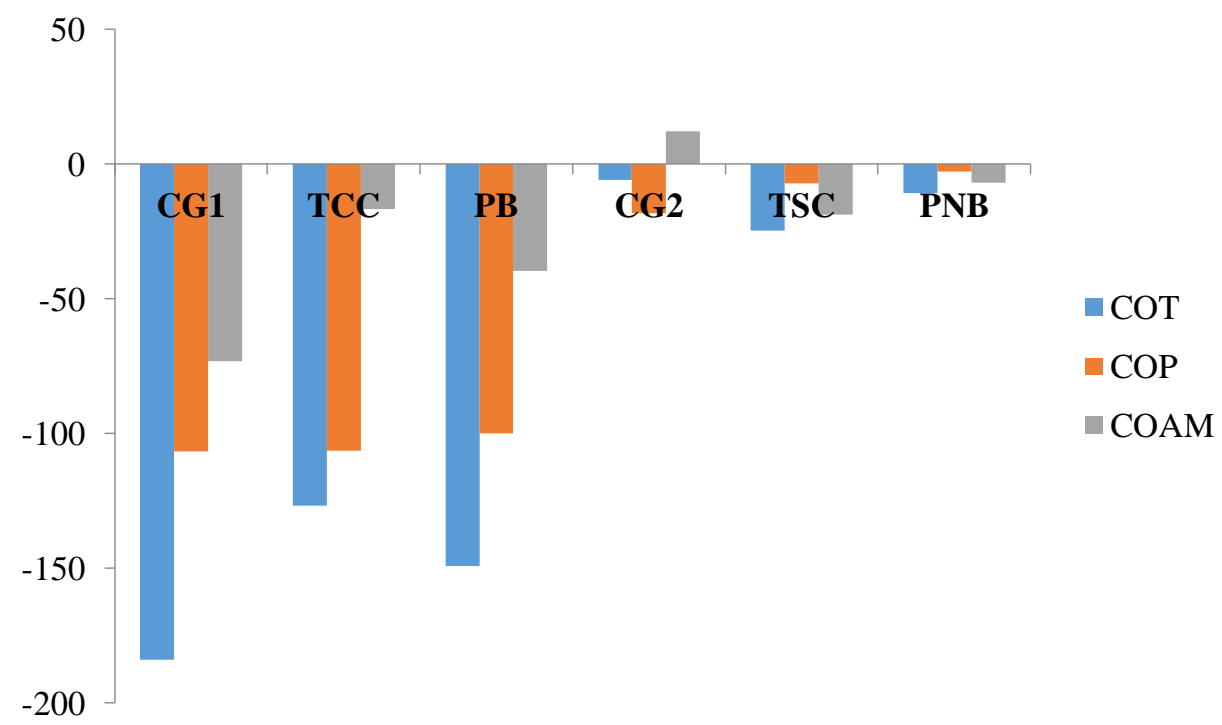

Figura 35. Redução e acréscimo dos estoques de carbono total (COT), carbono particulado (COP) e carbono associado aos minerais (COAM) nas diferentes frações da matéria orgânica sob sistemas de uso do solo em relação às áreas nativas (Cerradão e Cerrado sensu stricto). CER: cerradão; TCC: tangerina sem consórcio; PB: pastagem de braquiárias; CG1: plantio convencional de grãos; CSS: cerrado sensu stricto; TSC: plantio convencional de cultura perene; PNB: pastagem de plantas nativas e braquiárias; CG2: plantio convencional de grãos. 
De maneira geral a redução acentuada do $\Delta \mathrm{COT}$ e $\Delta \mathrm{COP}$ em todos os manejos, quando comparado com as áreas nativas. Os resultados reforçam a sensibilidade da fração mais lábil na detecção de alterações impostas pelo uso agrícola do solo, corroborando com os resultados de Sá \& Lal (2009), Figueiredo et al. (2010) e Carmo et al. (2012).

$\mathrm{Na}$ figura 36 são apresentados os valores de $\Delta \mathrm{N}$ em $\mathrm{Mg} \mathrm{ha}^{-1}$ para os diferentes sistemas estudados, tendo o solo do Cerradão e do Cerrado sensu stricto, como referências, representados pelo valor zero. Observa-se que os usos da terra PB, CG2 e TSC houve decréscimo dos estoques de NOT, NOP e NOAM.

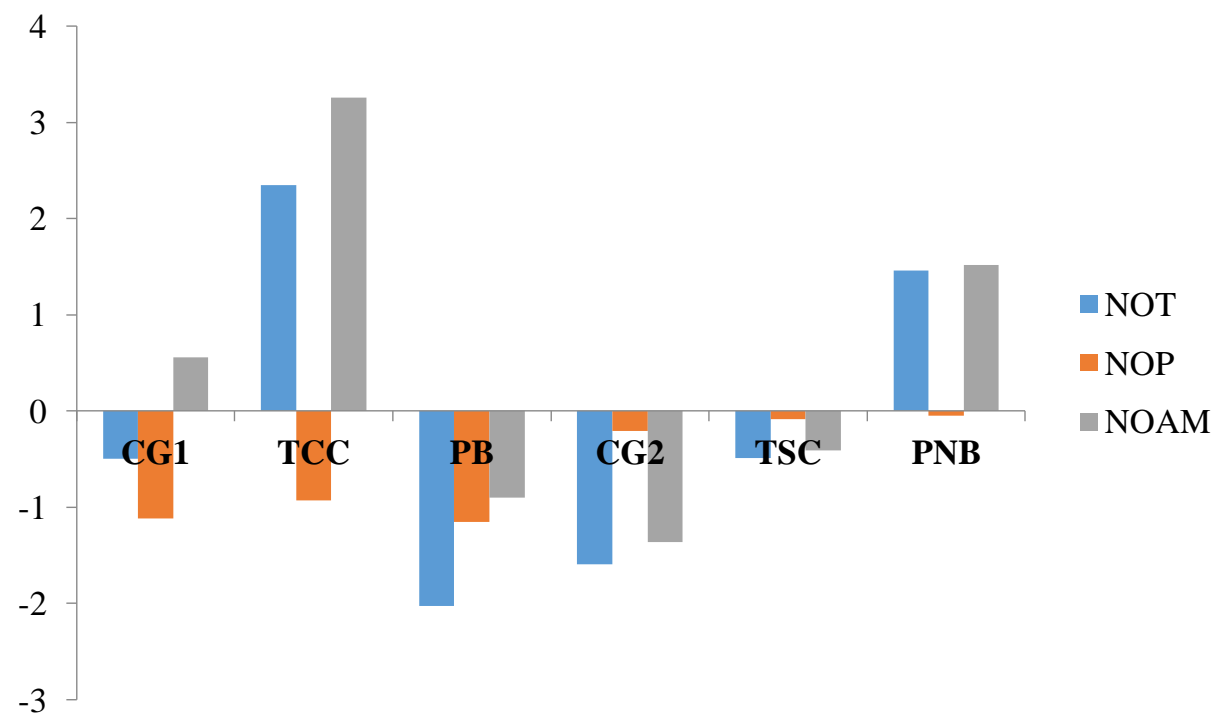

Figura 36. Redução e acréscimo dos estoques de nitrogênio total (NOT), nitrogênio particulado (NOP) e nitrogênio associado aos minerais (NOAM) nas diferentes frações da matéria orgânica sob sistemas de uso do solo em relação às áreas nativas (Cerradão e Cerrado sensu stricto). CER: cerradão; TCC: tangerina sem consórcio; PB: pastagem de braquiárias; CG1: plantio convencional de grãos; CSS: cerrado sensu stricto; TSC: plantio convencional de cultura perene; PNB: pastagem de plantas nativas e braquiárias; $\mathrm{CG} 2$ : plantio convencional de grãos. 
Nas áreas cultivadas sob Cerradão (CG1, TCC e PB), o PB reduziu o estoque de todas as frações do N. O manejo CG1 apresentou acréscimo apenas no estoque de NOAM, já o manejo TCC apresentou redução apenas no estoque de NOP, que é a fração mais lábil de N. No Cerrado sensu stricto, apenas a pastagem natural teve aumento nos estoques de NOT e NOAM e pequena redução de NOP (Figura 36).

\subsection{CONCLUSÕES}

1. O uso da terra com sistema conservacionista (tangerina com consórcio) foi o que menos alterou o compartimento total e as frações granulométricas de $\mathrm{C}$ e $\mathrm{N}$ da matéria orgânica do solo, em comparação com os demais usos da terra.

2. As áreas adubadas com nitrogênio (tangerina com e sem consórcio e plantio convencional de grãos) apresentaram maior teor de $\mathrm{N}$ total, do que o Cerradão, porém essa área nativa apresentou maior NOP.

3. Nas áreas sob Cerradão, a área nativa (Cerradão) apresentou os maiores valores de C total e das frações granulométricas;

4. Nas áreas sob Cerrado sensu stricto, as áreas nativas (Cerrado sensu stricto e a pastagem de plantas nativas e braquiárias) apresentaram maior valor de COT e COAM do que os demais usos da terra, porém o valor de COP foi semelhante em todos os usos. Ademais, a pastagem de plantas nativas e braquiárias apresentou maior $\mathrm{N}$ total e nas frações granulométricas do que os demais usos da terra.

\subsection{REFERÊNCIAS BIBLIOGRÁFICAS}

ALCÂNTARA NETO F., LEITE L.F.C., ARNHOLD E., MACIEL G.A., CARNEIRO F.V. Compartimentos de carbono em Latossolo Vermelho sob cultivo de eucalipto e fitofisionomias de cerrado. Revista Brasileira de Ciência do Solo 2011; 35: 849-856. 
BAYER, C.; MARTIN-NETO, L.; MIELNICZUK, J. \& CERETTA, C.A. Effect of notill cropping systems on soil organic matter in a sandy clay loam Acrisol from southern Brazil monitored by electron spin resonance and nuclear magnetic resonance. Soil Tillage Research, v. 53, p. 95-104, 2000.

BAYER, C.; MARTIN-NETO, L.; MIELNICZUK, J.; PAVINATO, A. Armazenamento de carbono em frações lábeis da matéria orgânica de um Latossolo Vermelho sob plantio direto. Pesquisa Agropecuária Brasileira, v.39, n.7, 2004, p.677683.

BEZERRA, R. P.M.; LOSS, A.; PEREIRA, M. G. \& PERIN, A. Formas de Carbono em Latossolo sob Sistemas de Plantio Direto e Integração Lavoura-Pecuária no Cerrado, Goiás. Ciência Agrária, v. 34, 2013, p. 2637-2654.

BLAIR, G. J.; CHAPMAN, L.; WHITBREAD, A. M., BAL-COELHO, B., LARSEN, P., TIESSEN H. Soil carbon changes resulting from trash management at two locations in Queensland, Australia and in Nort-east Brazil. Australian Journal of Soil Research, v.6, n.4, 1998, p.873-882.

BREMNER, J.M. Nitrogen total. In: SPARKS, D.L., ed. Methods of soil analysis. Part 3. Madison, America Society of Agronomy, 1996. p.1085-1121 (SSSA Book Series, 5).

CAMBARDELlA, C. A.; ELliOTT, E. T. Particulate soil organic-matter changes across a grassland cultivation sequence. Soil Science Society of America Journal, v.56, 1992, p.777-783.

CARMO, F.F.; FIGUEIREDO, C.C.; RAMOS, M.L.G. VIVLADI, L.J.; ARAÚJO, L.G. Frações granulométricas da matéria orgânica em latossolo sob plantio direto com gramíneas. Biosci. J., Uberlândia, v. 28, n. 3, 2012, p. 420-431.

CHRISTENSEN, B. T. Carbon in primary and secundary organomineral complexes. IN: CARTER, M. R.; STEWART, B. A. (Eds.). Structure and organic matter storage in agricultural soils. Boca Raton: CRC Lewis, 1996, p. 97-165.

COSER, T.R.; FIGUEIREDO, C.C.; RAMOS, M.L.G.; JANNUZZI, H.; MARCCHÃO, R.L. Recuperação de carbono obtido por três métodos em frações da matéria orgânica de Latossolo, sob consórcio milho-forrageiras, no cerrado. Bioscience Journal, 2012, 28:91-97. 
COSTA, E.M.; SILVA, H.F.; RIBEIRO, R.A. Matéria orgânica do solo e o seu papel na manutenção e produtividade dos sistemas agrícolas. ENCICLOPÉDIA BIOSFERA, Centro Científico Conhecer - Goiânia, v.9, n.17; 2013, p. 1842-1860.

DUXBURY, J.J.; SMITH, M.S. \& DORAN, J.W. Soil organic matter as a source and a sink of plant nutrients. In: COLEMAN, D.C.; OADES, J.M. \& UEHARA, G., eds. Dynamics of soil organic matter in tropical ecosystems. Honolulu, University of Hawaii, 1989. p.33-67.

FIGUEIREDO, C. C.; RESCK, D. V. S.; CARNEIRO, M. A. C. Labile and stable fractions of soil organic matter under management systems and native cerrado. Revista Brasileira de Ciência do Solo, v.34, 2010, p. 907-916.

GIÁCOMO, R.G.; GUARESHI, R.F.; PEREIRA, M.G.; MACHADO, D.L. MACHADO, Atributos químicos e físicos do solo, estoques de carbono e nitrogênio. Ciência Florestal, Santa Maria, v. 25, n. 3, 2015, p. 617-631.

KHORRAMDEL, S.; KOOCHEKI, A.; MAHALLATI, M.N.; KHORASANI, R.; GHORBANI, R. Evaluation of carbon sequestration potential in corn fields with different management systems. Soil \& Tillage Research, v.133, p.25-31, 2013.

PAUL, B.K.; VANLAUWE, B.; AYUKE, F.; GASSNER, A.; HOOGMOED, M.; HURISSO, T.T.; KOALA, S.; LELEI, D.; NDABAMENYE, T.; SIX, J.; PULLEMAN, M. M. Medium-term impact of tillage and residue management on soil aggregate stability, soil carbon and crop productivity. Agriculture, Ecosystems and Environment, v.164, 2013, p.14-22.

LOSS, A.; PEREIRA, M. G.; SCHULTZ, N.; FERREIRA, E. P.; SILVA, E. M. R. da; BEUTLER, S. J. Distribuição dos agregados e carbono orgânico influenciados por manejos agroecológicos. Acta Scientiarum Agronomy, v. 31, p. 523-528, 2009.

LOSS, A., PEREIRA, M. G., PERIN, A., COUTINHO, F. S., CUNHA, L. H. C. Particulate organic matter in soil under different management systems in the Brazilian Cerrado. Soil Research, v.50, 2012, p.685-693.

LOSS, A.; PEREIRA, M.G.; ANJOS, L.H.C.; GIACOMO, S.G.; PERIN, A. Agregação, carbono e nitrogênio em agregados do solo sob plantio direto com integração lavourapecuária. Pesquisa Agropecuária Brasileira, 2011, 46:1269-1276. 
MALHIA, S.S.; NYBORG. M.; SOLBERG, E.D.; DYCK, M.F.; PUURVEEN, D. Improving crop yield and $\mathrm{N}$ uptake with long-term straw retention in two contrasting soil types. Field Crops Research, v.124, 2011, p.378-391.

MOREIRA, F. M.; SIQUEIRA, J. O. Microbiologia e bioquímica do solo. Lavras: Universidade Federal de Lavras, 625 p. 2006.

NUNES, R.S.; LOPES, A.A.C.; SOUSA, D.M.G.; MENDES, I.C. Sistemas de manejo e os estoques de carbono e nitrogênio em latossolo de cerrado com a sucessão soja-milho. Revista Brasileira de Ciência do Solo, 35:1407-1419, 2011.

PERUSI, M.C.; AL ZAHER, C. Preparo conservacionista do solo no contexto da agricultura familiar, estudo de caso na microbacia do córrego fundo, município de Ourinhos/SP. São Paulo, UNESP, Geociências, v. 31, n. 4, 2012, p. 638-649.

PULROLNIK, K.; BARROS, N. F.; SILVA, I. R.; NOVAIS, R. F.; BRANDANI, C. B. Estoques de carbono e nitrogênio em frações lábeis e estáveis da matéria orgânica de solos sob eucalipto, pastagem e cerrado no Vale do Jequitinhonha - MG. Revista Brasileira de Ciência do Solo, Viçosa, v. 33, 2009, p. 1125-1136.

ROSCOE, R.; MERCANTE, F.M. \& SALTON, J.C. (Ed.). Biomassa microbiana do solo. In: ROSCOE, R.; MERCANTE, F.M. \& SALTON, J.C. (Ed.). Dinâmica da matéria orgânica do solo em sistemas conservacionistas: modelagem matemática e métodos auxiliares. Dourados, Embrapa Agropecuária Oeste, 2006. p.163-198.

SÁ, J.C.M.; SÁ, M.F.M.; SANTOS, J.B. \& FERREIRA, A.O. Dinâmica da matéria orgânica nos Campos Gerais. In: SANTOS, G.A.; SILVA, L.S.; CANELLAS, L.P. \& CAMARGO, F.A.O., eds. Fundamentos da matéria orgânica do solo - Ecossistemas tropicais e subtropicais. Porto Alegre, Metropole, 2008. p.443-462.

ROSSI, C. Q.; PEREIRA, M. G.; GIÁCOMO, S. G.; BETTA, M.; POLIDORO, J. C. Frações lábeis da matéria orgânica em sistema de cultivo com palha de braquiária e sorgo. Revista Ciência Agronômica, Fortaleza, v.43, n.1, 2012, p.38-46.

SAltON, J. C.; MIELNICZUK, J.; BAYER, C.; FABRÍCIO, A. C.; MACEDO, M. C. M.; BROCH, D. L. Teor e dinâmica do carbono no solo em sistemas de integração lavoura-pecuária. Pesquisa Agropecuária Brasileira, v.46, n.10, 2011, p.1349-1356. 
SANTOS, M.E.R.; FONSECA, D.M.; EUCLIDES, V.P.B. et al. Valor nutritivo da forragem e de seus componentes morfológicos em pastagens de Brachiaria decumbens diferida. Boletim e Indústria Animal, v.65, n.4, p.303-311, 2008.

SANTOS, N.Z.; DIECKOW, J.; BAYER, C.;MOLIN, R.; FAVARETTO, N.; PAULETTI, V. \& PIVA, J.T. Forages, cover crops and related shoot and root additions in no-till rotations to $\mathrm{C}$ sequestration in a subtropical Ferralsol. Soil Till. Res., 111:208$218,2011$.

SCHIAVO, J.A.; ROSSET, J.S.; PEREIRA, M.G.; SALTON, J.C. Índice de manejo de carbono e atributos químicos de Latossolo Vermelho sob diferentes sistemas de manejo. Pesquisa Agropecuária Brasileira, 46:1332-1338, 2011.

SILVA, A.S.; SILVA, I.F.; SILVA NETO, L.F. \& SOUZA, C. Semeadura direta na produção do milho em agricultura de sequeiro na região nordeste do Brasil. Ci. Rural, 2011. 41:1556-1562.

SOUZA, C.A.; REIS JUNIOR, F.B.; MENDES, I.C.; LEMAINSKI, J. SILVA, J.E. Lodo de esgoto em atributos biológicos do solo e na nodulação e produção de soja. Pesquisa Agropecuaria Brasileira, 44:1319-1327, 2009.

SOUZA, G.P. Frações lábeis e humificadas do carbono orgânico do solo em Sistemas de manejo com sucessão soja-milho no cerrado. Brasília, 2013. 102 p. (Dissertação de Mestrado).

URQUIAGA, S.; JANTALIA, C. P.; ZOTARELli, L.; ALVES, B. J. R. \& BODDEY, R. M. Manejo de sistemas agrícolas para o sequestro de carbono no solo. In: AQUINO, A. M. \& ASSIS, R. L., org. Conhecimentos e técnicas avançadas para o estudo dos processos da biota no sistema solo-planta. Brasília, Embrapa, p.257-273, 2005.

VIEIRA, C.R.; WEBER, O.L.S.; JARDINI, D.C. Distribuição do carbono orgânico e do nitrogênio total nas frações granulométricas de um Latossolo sob diferentes tipos de vegetações. REA - Revista de estudos ambientais (Online) v.17, n. 1, 2015, p. 43-53.

WALKLEY, A.; BLACK, I. A. An examination of the Degtjareff method for determining soil organic matter and a proposed modification of the chromic acid titration method. Soil Science, v.37, p.29- 38, 1934. 
WENDLING, B.; VINHAL-FREITAS, I.C.; OLIVEIRA, R.C.; BABATA, M.M.;BORGES, E.N. Densidade, agregação e porosidade do solo em áreas de conversão do cerrado em floresta de pinus, pastagem e plantio direto. Biosci. J., Uberlândia, v. 28, Supplement 1, 2012, p. 256-265.

WINK, B.R.; VEZZANI, F.M.; DIECKOW, J.; FAVARETTO, N.; MOLIN, R. Carbono e nitrogênio nas frações granulométricas da matéria orgânica do solo, em sistemas de culturas sob plantio direto. R. Bras. Ci. Solo, 2014, 38:980-989. 